\title{
Proteomic analysis of Saccharomyces cerevisiae grown on glucose or glycerol
}

By

Hannah D Hoang

A thesis submitted to Victoria University of Wellington in the fulfillment of the requirements for the degree of Master of Science in Cell and Molecular Bioscience 



\section{Acknowledgements}

This has been quite an adventure and I am grateful to all of the amazing people who have supported me throughout the course of this project.

Firstly, I would like to thank my supervisor, Dr Bill Jordan for this research opportunity. Thank you for your patience, guidance, support, and music suggestions. I have had a wonderful time learning about yeast proteomics.

A special thanks to some pretty amazing 'proteomicists'. Dr Pisana Rawson, thank you for taking time to teach me 2DE, it was cool to learn from the best. Dr Jonathan Dunne, thank you for your help on mass spectrometry (and formatting). A big thanks to Sarah Cordiner, you're an awesome lab partner. Danyl McLauchlan, thank you for helping out with anything related to bioinformatics.

To Dr Paul Atkinson and the chemical genetics group, thank you for gifting BY4741 and allowing me to work in your chemical genetics lab. It has been a real treat having a second lab family.

I would also like to acknowledge the fellow students, past and present, who I have come to know, in particular, Ploi Yibmantasiri, Janice Cheng, Nathaniel Dasaym, Bede Busby, Peter Birchirm, Katie Zeier, and Dr Christine Stockholm. Thank you for sharing your time and friendship.

Lastly, to my family, you have been such a great support group. Thank you all so much!!! 


\section{Abstract}

The goal of this research was to use two-dimensional electrophoresis to examine changes in abundance of enzymes of the glycolytic pathway in the yeast Saccharomyces cerevisiae grown on carbon sources that support either fermentation to ethanol or oxidative metabolism. Large-scale profiling of protein abundances (expression proteomics) often detects changes in protein abundance between physiological states. Such changes in enzyme abundance are often interpreted as evidence of metabolic change although most textbooks emphasise control of enzyme activities not enzyme amount. Two-dimensional difference gel electrophoresis (2DDIGE) was therefore used to examine differences in protein abundance between $S$. cerevisiae strain BY4741 grown on either glucose (fermentation) or glycerol. Growth on $2 \%$ glucose, but not on glycerol, was accompanied by extensive production of ethanol. Doubling times for growth were $2 \mathrm{~h} 5 \mathrm{~min}$ in glucose and $9 \mathrm{~h} 41 \mathrm{~min}$ in glycerol.

Conditions for extraction and two-dimensional electrophoresis of proteins were established. One hundred and seventy nine proteins were identified by MALDI mass spectrometry of tryptic digests of protein spots excised from Coomassie stained gels. All of the enzymes for conversion of glucose to ethanol, except for the second enzyme of glycolysis phosphoglucose isomerase, were identified using twodimensional electrophoresis of $100 \mu \mathrm{g}$ of protein from cells grown on $2 \%$ glucose. Identification of proteins excised from the DIGE gels was more challenging, partly because of the lower amount of protein. Eight of the proteins that showed statistically significant differences in abundance ( 2 -fold, $p \leq 0.01$ ) between glucose and glycerol were identified by mass spectrometry of proteins excised from the 2DDIGE gels, and a further 18 varying proteins were matched to proteins identified from the Coomassie stained gels. Of these total 26 identified or matched proteins, subunits of five of the enzymes for conversion of glucose to ethanol were more abundant from the fermentative cells grown on glucose. The more abundant glycolytic enzymes were phosphofructokinase 2, fructose-1,6-bisphosphate aldolase, triosephosphate isomerase and enolase, plus pyruvate decarboxylase that was required for conversion of the glycolytic product pyruvate to acetaldehyde. The 
alcohol dehydrogenases Adh1 and Adh4 that convert acetaldehyde to ethanol were detected but did not vary significantly between growth on glucose or glycerol. The results confirmed that in this case changes in abundance of some enzymes were consistent with the altered metabolic output. Future studies should examine whether changes in the abundance and activity of these enzymes are responsible for the differences in metabolism. 


\section{Abbreviations}

1D

One-dimensional

2D-DIGE Two-dimensional-differential in gel electrophoresis

2DE Two-dimensional electrophoresis

ACN Acetonitrile

CBB G-250 Coomassie Brilliant Blue G-250

CHAPS 3-[(3-Cholamidopropyl)dimethylamonio]-1-propanesulfonate

CHCA $\quad \alpha$-Cyano-4-hydroxycinnamic acid

DIGE Differential in gel electrophoresis

DTT Dithiothreitol

GE Gel Electrophoresis

IAA Iodoacetamide

IEF Isoelectric focusing

IPG Immobilized $\mathrm{pH}$ gradient

MALDI Matrix assisted laser desorption ionisation

MS Mass Spectrometry

pI Isoelectric point

PMF Peptide mass fingerprinting

SDS Sodium dodecyl sulphate

TFA Trifluoroacetic acid

Tris Tris(hydroxymethyl)aminomethane 


\section{Table of Contents}

Acknowledgements .............................................................................................................................iii

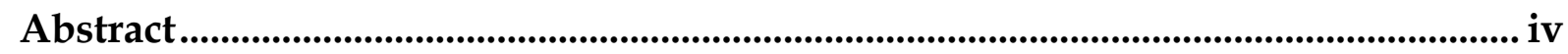

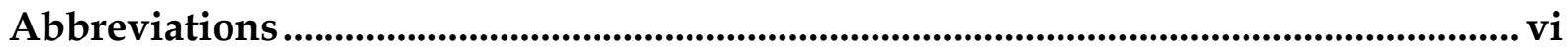

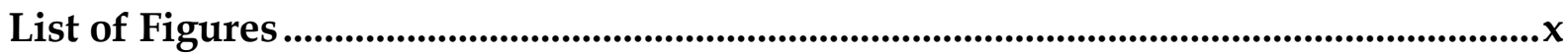

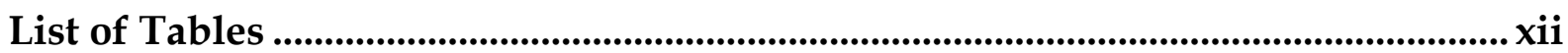

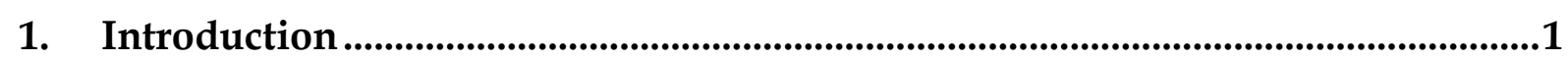

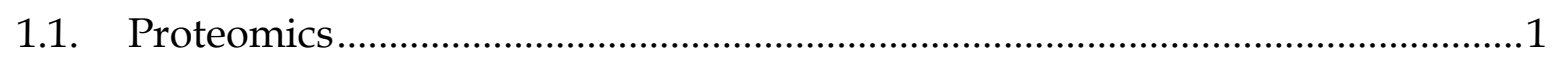

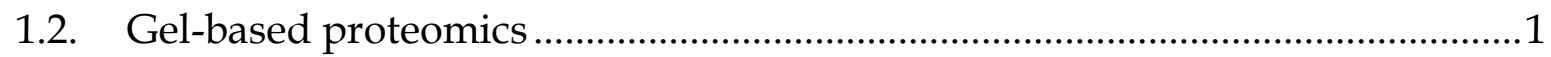

1.2.1. Two-dimensional gel electrophoresis ..........................................................

1.2.2. Difference gel electrophoresis...............................................................

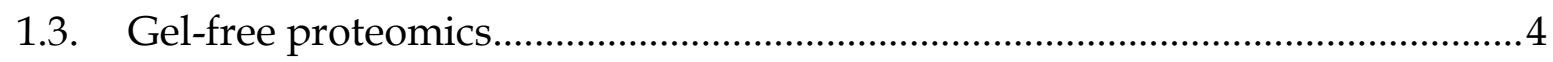

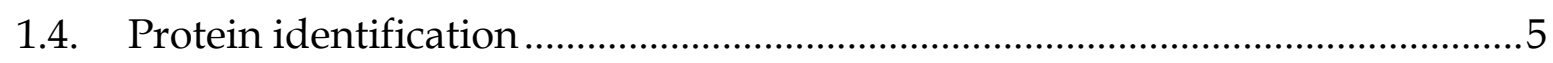

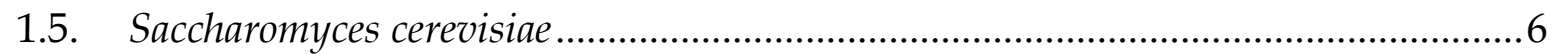

1.5.1. Carbohydrate metabolism in S. cerevisiae ..................................................6

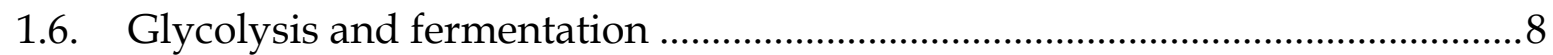

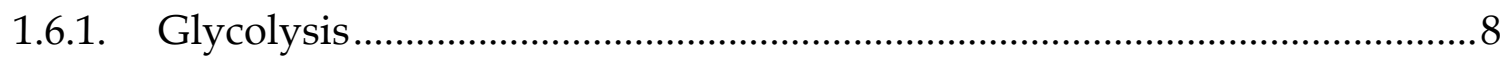

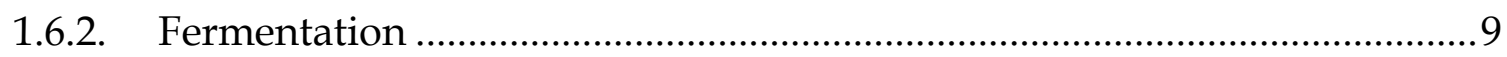

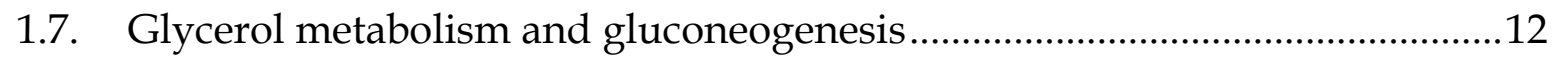

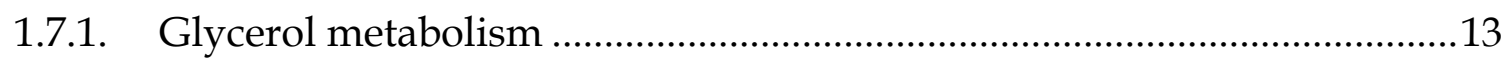

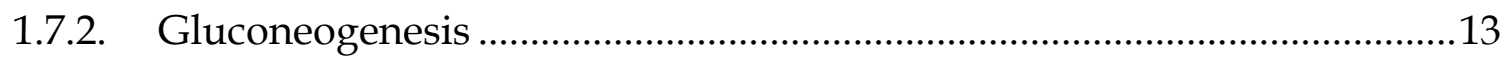

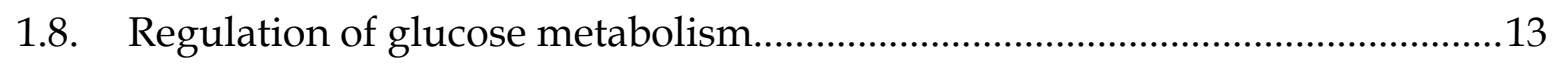

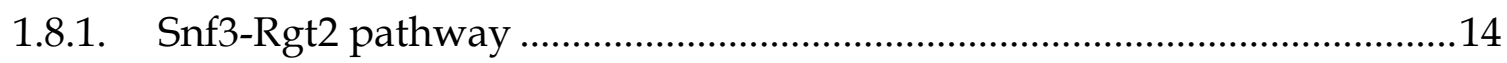

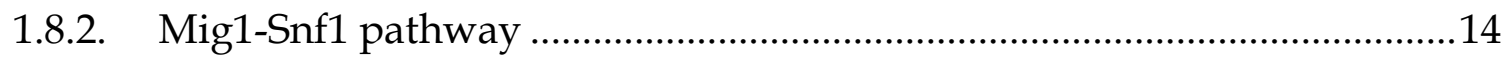

1.9. Transcriptomic analysis of carbon substrate metabolism ..............................17

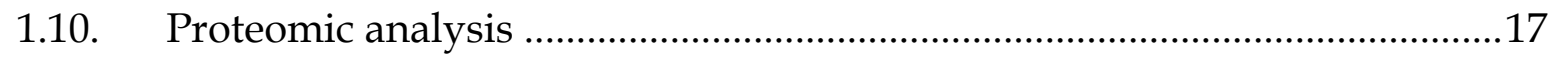

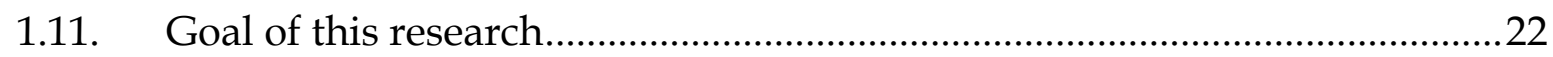




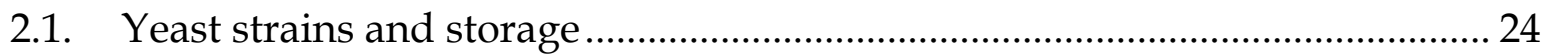

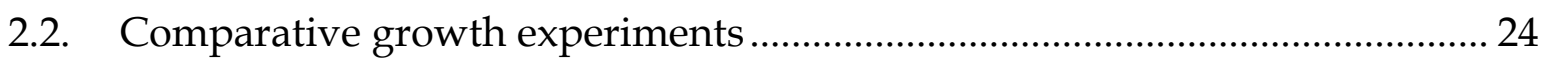

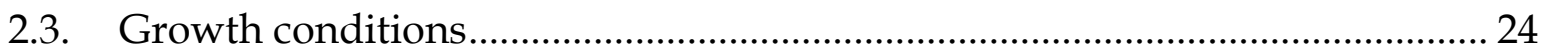

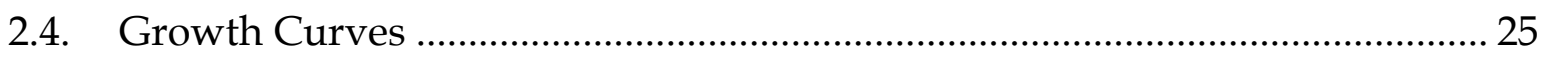

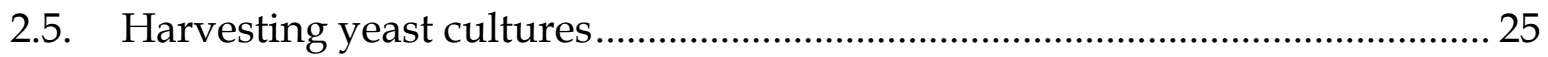

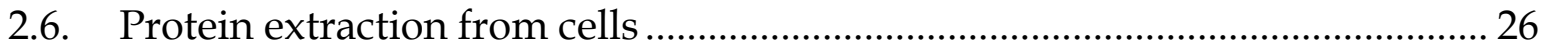

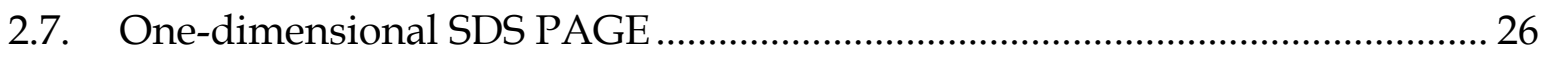

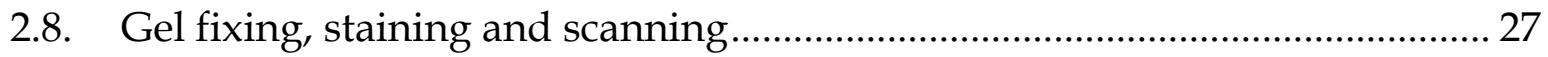

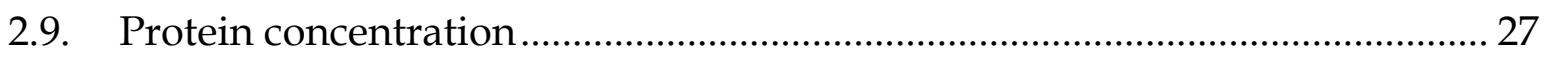

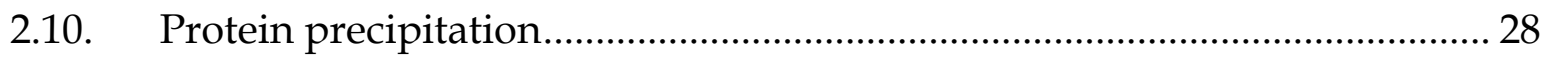

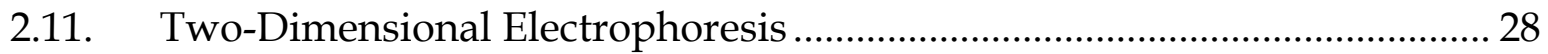

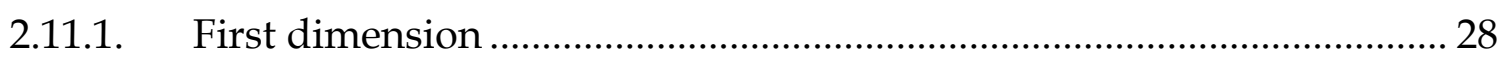

2.11.2. Sample preparation for passive rehydration......................................... 28

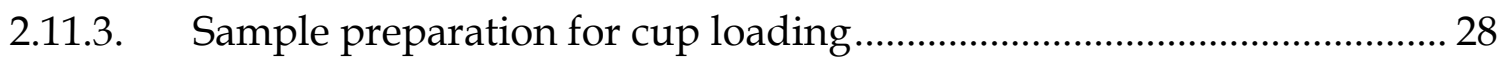

2.11.4. Isoelectric focusing using a Multiphor II system .................................. 29

2.11.5. Second dimension - SDS PAGE ........................................................... 29

2.12. Protein spot picking, destaining of protein spots and trypsin digestion ... 30

2.13. Preparation of samples for MALDI MS/MS .............................................. 30

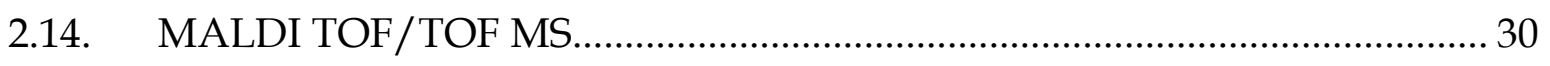

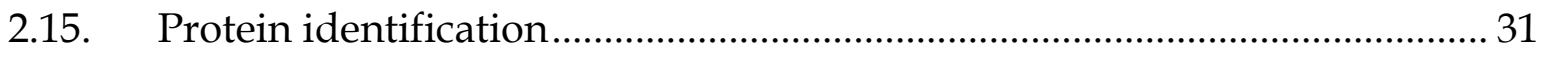

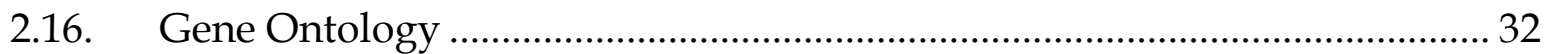

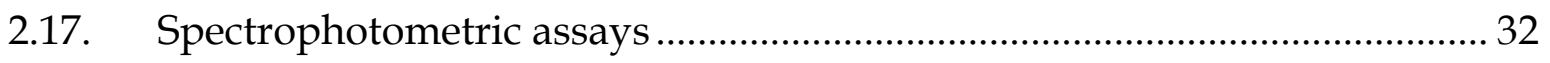

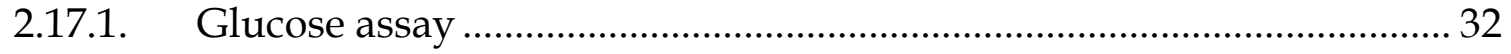

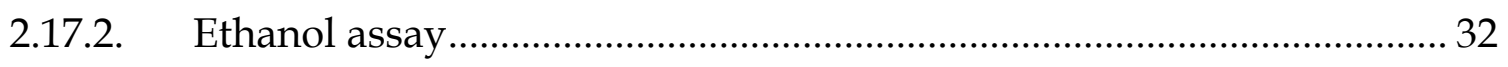

2.18. Differential in Gel Electrophoresis (DIGE) …......................................... 32

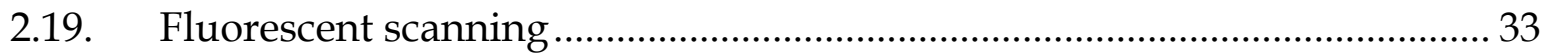

2.20. Preparation of gel images for DeCyder ${ }^{\mathrm{TM}}$ analysis..................................... 34

2.21. Data analysis using Decyder ${ }^{\mathrm{TM}}$ software ….................................................. 34 


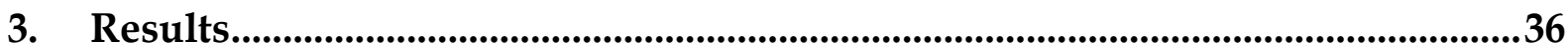

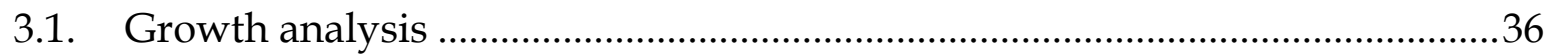

3.2. Extraction protocols and optimization of separation techniques for 2D

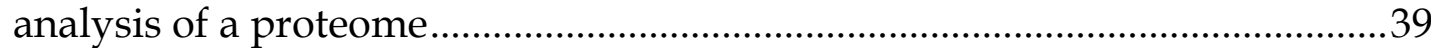

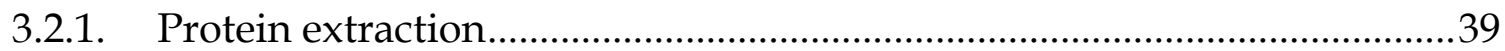

3.2.2. Separation of yeast proteins by $2 \mathrm{DE}$ using different $\mathrm{pH}$ ranges on $7 \mathrm{~cm}$

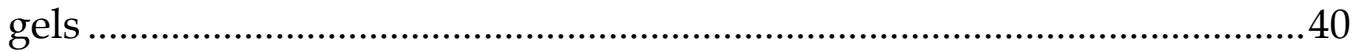

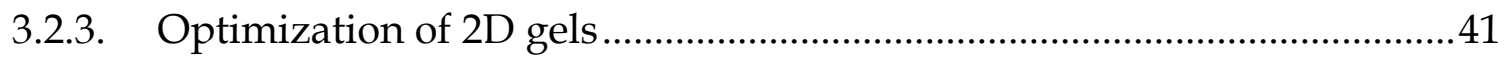

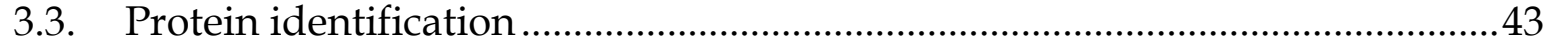

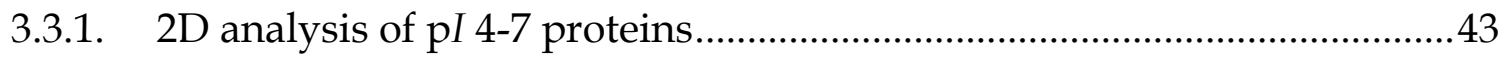

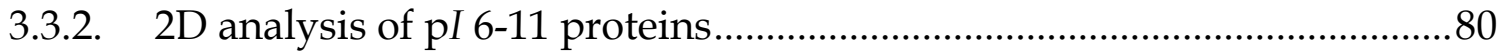

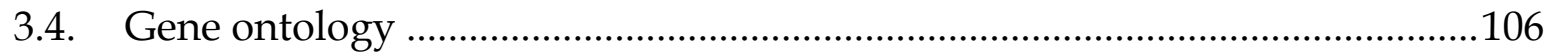

3.5. Measurement of glucose use and ethanol production .................................111

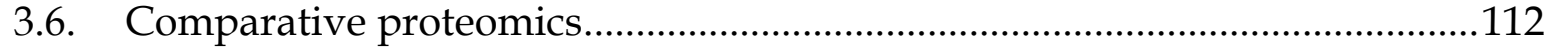

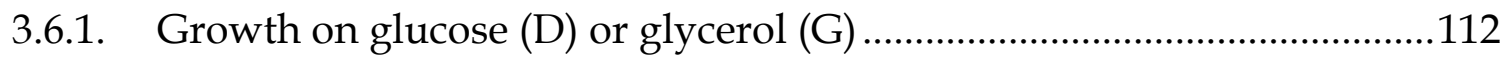

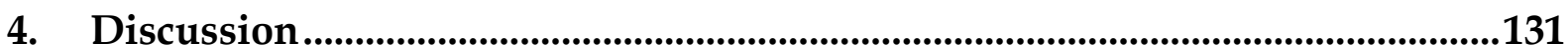

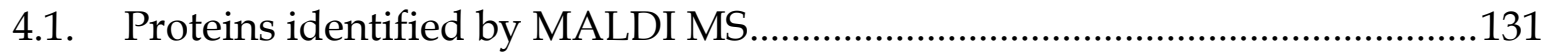

4.2. Carbohydrate and ethanol metabolism .......................................................... 133

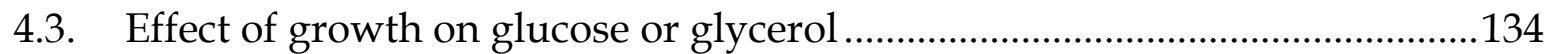

4.4. Changes associated with carbohydrate metabolism...................................139

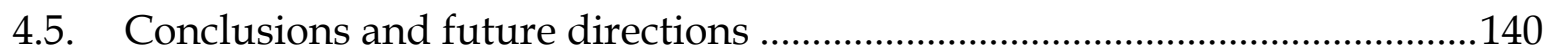

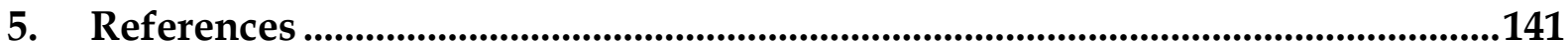




\section{List of Figures}

Figure 1 - Summary of the DIGE labeling process............................................................ 4

Figure 2 - A simplified diagram of glucose metabolism in S. cerevisiae ........................... 7

Figure 3 - Proteins and metabolites involved in glycolysis............................................. 8

Figure 4 - Proteins and metabolites involved in glycerol metabolism, gluconeogenesis/ glycolysis.

Figure 5 - The induction and repression of genes involved in the Snf3-Rgt2 (left) and Mig1-Snf1 (right) pathways of S. cerevisiae. 16

Figure 6 - Proteomic analysis of S. cerevisiae grown in glucose (dextrose) or glycerol based media by Stobaugh et al. (2013). 22

Figure 7 - Growth conditions of BY4741 for the analysis of fermentative and oxidative metabolism

Figure 8 - Growth of BY4741 in 2\% glucose (top) or 3\% glycerol (bottom) and SC media.

Figure 9 - $\log _{10}$ growth curves of BY4747 in 2\% glucose (top) or 3\% glycerol (bottom) and SC media. 38

Figure 10 - Comparison of protein extraction methods analyzed by 1D SDS PAGE.

Figure 11 - Two-dimensional gel electrophoresis using three different $7 \mathrm{~cm}$ gradients for IEF.

Figure 12 - Optimization of IEF. The experiment compared precipitated (left) against non-precipitated (right) protein samples.

Figure 13 - The 2D gel image of the protein profile of S. cerevisiae BY4741 separated on a $\mathrm{pH} 4-7$ linear gradient (horizontal axis).

Figure 14 - The 2DE image representing the protein $(100 \mu \mathrm{g})$ profile of BY4741 separated on a $\mathrm{pH}$ 6-11 gradient. 
Figure 15 - Gene ontology annotations of the functions of protein identified from the reference protein maps (Figure 13 and Figure 14). 108

Figure 16 - Two-dimensional gel images of BY4741 proteins $(100 \mu \mathrm{g})$ separated on $\mathrm{pH}$ 4-7 (Figure 13, top) or pH 6-11 (Figure 14, bottom) IPG strips. 110

Figure 17 - Two-dimensional images of the DIGE experiment portraying the differences in protein abundance between BY4741 cells grown in glucose (red) and glycerol (blue)....

Figure 18 - Comparative gene ontology annotations of the functions between proteins identified for the reference protein map (red) and proteins identified from the glucose vs. glycerol DIGE experiment (blue).

Figure 19 - Identified proteins (red box) involved in glucose and glycerol metabolism.

Figure 20 - Coomassie stained 2D-DIGE gel of the glucose vs. glycerol experiment.

Figure 21 - Proteins involved in glucose and glycerol metabolism. 138 


\section{List of Tables}

Table 1 - The five S. cerevisiae Adh isoforms involved in ethanol metabolism.

Table 2 - Settings of the Multiphor II system for isoelectric focusing using pH 3-11

NL, 4-7 or 6-11 IPG strips.

Table 3 - The DIGE labeling design for the comparison of glucose (D) and glycerol (G) grown cells.

Table 4 - Excitation wavelengths for each Cy dye and the type of emission filter used for each wavelength. 34

Table 5 - Summary of identified BY4741 proteins by MALDI mass spectrometry and separated by 2DE using a $\mathrm{pH}$ 4-7 gradient. 45

Table 6 - A summary of identified BY4741 proteins separated on a 6-11 pH gradient.

Table 7 - Identified proteins from the reference protein map (Table 5 and Table 6) that were involved in central carbohydrate metabolism (Figure 15)

Table 8 - Glucose consumption and ethanol production of $0.2 \%$ (low), $0.5 \%$ (medium) and $2 \%$ (high) glucose grown yeast cells (A) and 3\% glycerol vs. $2 \%$ glucose grown cells $(\mathrm{B})$.

Table 9 - Proteins identified from the glucose versus glycerol grown DIGE experiment $(\mathrm{p} \leq 0.01)$

Table 10 - Possible protein identifications for the glucose vs. glycerol DIGE experiment.

Table 11 - Proteins identified from the simplified glucose vs. glycerol grown DIGE experiment.

Table 12 - Components of complex V of the electron transport chain. 132

Table 13 - The twenty-six varying proteins associated with growth on glucose. .... 136 


\section{Introduction}

The goal of this project was to use two-dimensional electrophoresis (2DE)-based proteomics to examine changes in protein abundance between fermentative and oxidative metabolism in the yeast Saccharomyces cerevisiae. Metabolic pathways can be regulated by changing enzyme activities and enzyme amounts. Many proteomic studies, including examination of metabolic change, assume that change in enzyme abundance is related to change in metabolic output. Although this is sometimes the case (Rawson et al., 2012) many enzymes are regulated by substrates, products, allosteric effectors or post-translational modification independent of enzyme amount. This project therefore uses proteomics to investigate potential differences in amount of enzymes that affect carbohydrate metabolism and ethanol synthesis under conditions when either ethanol production or oxidative metabolism predominates.

\subsection{Proteomics}

Proteomics is a set of techniques that can be used to profile the protein content of biological samples (Pham \& Wright, 2007). Of particular interest for this project is quantitative proteomics, the ability to compare protein profiles under different conditions. Proteomic workflows can be simplified into the separation of complex protein mixtures coupled to protein identification. Separation of proteins can be divided into gel-based and gel-free techniques. Both have advantages and disadvantages as discussed later. Gel-based analysis by 2DE is used in this project. Protein identification is now commonly done by mass spectrometry with matching of sequence-based peptide masses to sequence databases.

\subsection{Gel-based proteomics}

\subsubsection{Two-dimensional gel electrophoresis}

In 1975 Patrick O'Farrell and Joachim Klose independently developed 2DE (Klose, 1975; O'Farrell, 1975). This technique uses two sequential episodes of protein separation. In the first phase of separation, proteins migrate to their $\mathrm{pI}$ using isoelectric focusing (IEF). The second dimension separates focused proteins according to their molecular mass using sodium dodecyl sulfate polyacrylamide gel electrophoresis (SDS-PAGE). The 2DE method is transformed by coupling pre- 
electrophoretic labeling of protein samples with fluorescent Cy dyes allowing quantitative analysis of multiple sample sets (Unlu et al. (1997).

Isoelectric focusing (IEF) separates protein mixtures by applying an electric field to a pH gradient (Klose, 1975; O'Farrell, 1975). Proteins migrate to their isoelectric point where they are no longer charged. As they are amphoteric molecules their overall charge is determined by their side chains in that environment. Thus a protein with an overall positive charge would migrate towards the cathode and in a contrasting situation a protein with a net negative charge would migrate towards the anode. Isoelectric focusing of proteins for 2DE was originally carried out in PAGE tube gels but was simplified by Angelika Gorg and Pier Righetti who independently developed immobilized pH gradients (IPG) (reviewed by Righetti and Bossi (1997)). IPG strips contain acid and basic buffering groups that are covalently incorporated into acrylamide gels attached to a thin layer of plastic. This development facilitated reproducible focusing over broad or narrow $\mathrm{pH}$ ranges including the highly acid and basic regions of the $\mathrm{pH}$ scale.

Size-based separation of proteins in the second dimension uses SDS-PAGE (Klose, 1975; O'Farrell, 1975). Proteins which have been fixed at their isoelectric point by IEF are equilibrated in an SDS solution for the formation of SDS-protein complexes. SDS is an anionic detergent that binds proteins and confers mass-based charge that allows size separation in polyacrylamide gels.

\subsubsection{Difference gel electrophoresis (DIGE)}

Prior to the development of DIGE in 1997 (Unlu et al., 1997) the standard method for comparative 2DE was to match gels that had been stained for proteins after electrophoresis. Matching was limited by variability in protein loading and staining and the reproducibility of spot matching methods. Unlu et al. (1997) described DIGE using fluorescent cyanine (Cy) dyes containing an N-hydroxysuccinimidyl (NHS) ester reactive group for the labeling of protein samples prior to IEF. The Cy dyes $\mathrm{Cy} 2, \mathrm{Cy} 3$ and Cy5 are used to label up to three protein samples for analysis on one gel. The Cy dyes can be used for minimal or saturation (for low protein abundance samples) labeling of protein sets. For minimal labeling, the NHS moiety of the Cy dyes covalently bind to lysine residues of proteins by an amide bond. Cy dyes carry 
a single intrinsic positive charge, as do lysine residues in acidic conditions, and upon attachment to a lysine the positive charge is replaced causing no significant change in the $\mathrm{p} I$ of the protein. It is often advantageous to incorporate an internal standard composed of equal amounts of all of the protein samples labeled with Cy2 to facilitate gel matching between replicates (Karp \& Lilley, 2005). The Cy dyes are separately added to each condition, including the internal standard before they are separated in the first and second dimensions by 2DE (Figure 1). Computer-aided image analysis is used to determine differences in protein abundance among samples. There are several advantages of using 2DE combined with DIGE for comparative proteomic analysis. Two-dimensional electrophoresis allows visual and computational analysis of differences in protein abundance between samples, and of changes in protein spot position (mass or $\mathrm{p} I$ ) in gels that can be due to posttranslational modification of proteins. Statistical analysis of changes in protein abundance is enhanced by uniform matching of protein spots by comparison with the internal standard protein mixture that is included in all gels. Disadvantages of gel-based methods include the time consuming aspects of the experiments and the difficulty to detect low abundance proteins (Pham \& Wright, 2007). 


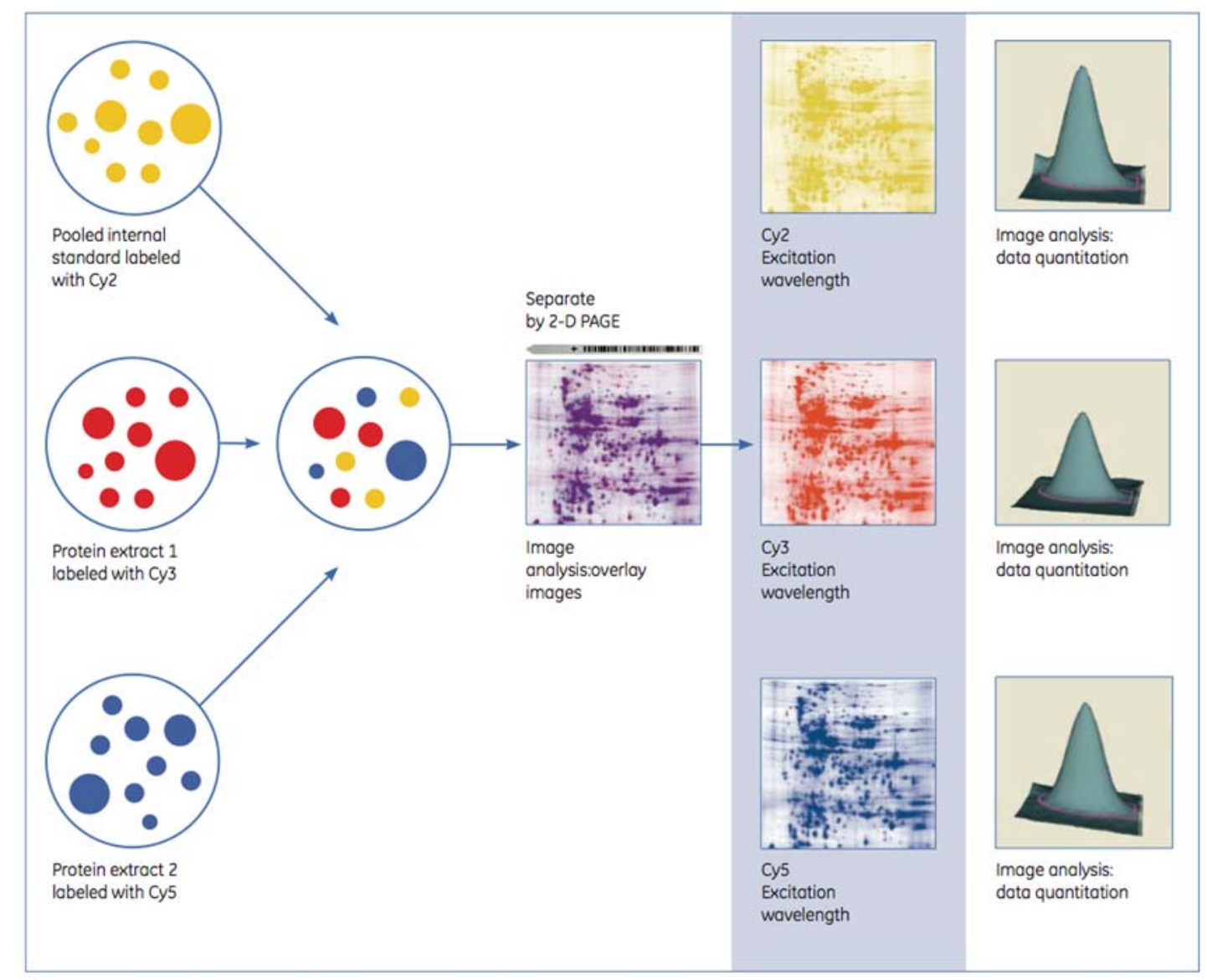

Figure 1 - Summary of the DIGE labeling process. Protein extracts of each condition are labeled with Cy dyes. Images of each Cy dye labeled protein set are visualized by excitation at a certain wavelength and are overlaid for image analysis. An internal standard of all proteins included in the analysis is labeled with Cy2 and is used as the reference for spot matching on each gel. Copyright for use of this image was approved by GE Healthcare.

\subsection{Gel-free proteomics}

As an alternative or complementary strategy to 2DE, gel-free techniques use mass spectrometry based analysis of proteolytic digests of proteins (Pham \& Wright, 2007). Protein samples are digested to give large sets of peptide fragments that are separated by liquid chromatography prior to tandem mass spectrometry for peptide and protein identification. The enzyme trypsin that cleaves peptide bonds on the Cterminal side of arginine or lysine is often used as the proteolytic reagent. This general approach can be called LC MS/MS, gel-free analysis, or shotgun proteomics. Quantitative methods include spectral counting (a label-free method) and isotopic labeling. In spectral counting the number of times a peptide detected is used as a 
measure of protein abundance (Lundgren et al., 2010). Alternatively, incorporation of isotopic labels for the tagging of proteins can be used to measure changes in protein abundance. Two of the commonly used methods of isotopic labeling are SILAC (Stable Isotope Labeling And Culture) and iTRAQ (Isobaric Tags for Relative and Absolute Quantification) (Brewis \& Brennan, 2010).

SILAC was originally designed for mammalian samples but the technique has been adapted for yeast, bacteria and plant cultures (Ong \& Mann, 2006). The technique involves the incorporation of a stable isotope-labeled essential amino acid into a cell culture lacking the same essential amino acid. For SILAC, cells are grown in medium containing amino acids such as arginine or lysine labeled with ${ }^{13} \mathrm{C}$ or ${ }^{15} \mathrm{~N}$ stable isotopes and for comparison of protein change are mixed with cells grown in natural abundance $\left({ }^{12} \mathrm{C}\right.$ or $\left.{ }^{14} \mathrm{~N}\right)$ amino acids. Shotgun mass spectrometry is then used to detect peptides that differ in the ratio of heavy and light isotopic labels that reflect differences in protein abundance between samples. A major advantage of isotopic labeling is the sensitivity of the tags and the ability to detect low abundance proteins that is a major limiting factor of 2D based techniques.

For iTRAQ, samples are chemically labeled with amine specific reagents containing stable isotopes and a mixing protocol is used to compare the abundances of digest peptides and hence their parent proteins from different samples. The first application of iTRAQ in yeast was done by Ross et al. (2004). The shotgun approach compared a wildtype strain with two mutant strains. Subsequently, Pham et al. (2006) examined the proteomes of wildtype yeast grown in media supplemented with $12 \%, 21 \%$ or $30 \%$ glucose. Protein separation and identification was completed using LC MS/MS resulting in detection of 413 proteins. Differences among enzymes involved in carbohydrate and amino acid metabolism were detected. Subsequent studies are outlined later in this Introduction.

\subsection{Protein identification}

Regardless of the method for protein separation, mass spectrometry has become the standard for protein identification (Pham \& Wright, 2007). A common mass spectrometric method for the identification of proteins involves peptide mass fingerprinting (PMF) using MALDI TOF (matrix assisted laser desorption ionization 
time of flight) or electrospray ionization (ESI) mass spectrometry (MS). Sequencespecific peptide fragments are created by cleaving proteins with an enzyme with high specificity. Trypsin is a commonly used proteolytic agent which cleaves proteins at the C-terminal residue of arginine or lysine. MS-based peptide masses are then used to match to sequence databases for probability based protein identification. More specific matching is obtained using MS/MS to measure sequence-based fragments of the peptides that are generated in the mass spectrometer.

\subsection{Saccharomyces cerevisiae}

The budding yeast $S$. cerevisiae is a well-studied organism. The single celled eukaryote had its genome sequence reported in April 1996 revealing a 16 kb genome with six chromosomes (Goffeau et al., 1996). Thirty percent of the yeast genome is homologous with the human genome making it an excellent model for research using molecular biological tools such as the yeast gene deletion set (Giaever et al., 2002), and red fluorescent protein (RFP), green fluorescent protein (GFP) (Bisson \& Fraenkel, 1983) and TAP-tagged libraries (Babu et al., 2009). Large-scale coverage of the yeast proteome has also been reported (de Godoy et al., 2008; Picotti et al., 2013; Shevchenko et al., 1996). There are several online resources that are readily available including the Kyoto Encyclopedia of Genes and Genomes (KEGG, http://www.genome.jp/kegg and the Yeast Genome Database (SGD, http://www.yeastgenome.org/).

\subsubsection{Carbohydrate metabolism in S. cerevisiae}

S. cerevisiae has the ability to grow under a variety of conditions, in particular on many carbon substrates. One characteristic of this yeast is fermentation of glucose to ethanol under aerobic or anaerobic conditions. The specific conditions relevant to this thesis research are growth on glucose or glycerol. Growth on glucose utilizes the glycolytic pathway to produce pyruvate that can be metabolized to ethanol and carbon dioxide (fermentation). In contrast, fermentation does not occur during growth on glycerol. Glycerol can be used for synthesis of glucose (gluconeogenesis) or for energy production using glycolysis coupled to the citric acid cycle and oxidative phosphorylation. 
S. cerevisiae can grow on a number of sugars such as fructose and mannose but prefers glucose. There are 18 hexose transporters and at least six are specific for glucose transport. Each glucose transporter has a different affinity for glucose to suit substrate availability. In high glucose conditions regardless of oxygen, glucose is directed into the cell via the low glucose affinity Hxt1 transporter and fermented to produce ethanol and carbon dioxide (Ozcan \& Johnston, 1995). Metabolism of glucose is directed through glycolysis with the upregulation of genes involved in ethanol synthesis and the repression of genes responsible for other pathways of utilization (Figure 2). This is known as the glucose repression effect (Gancedo, 1992). In contrast, when glucose is limited, glucose is not fermented to produce ethanol but is fully oxidized to produce $\mathrm{CO}_{2}$ via the TCA acid cycle (Postma et al., 1989).

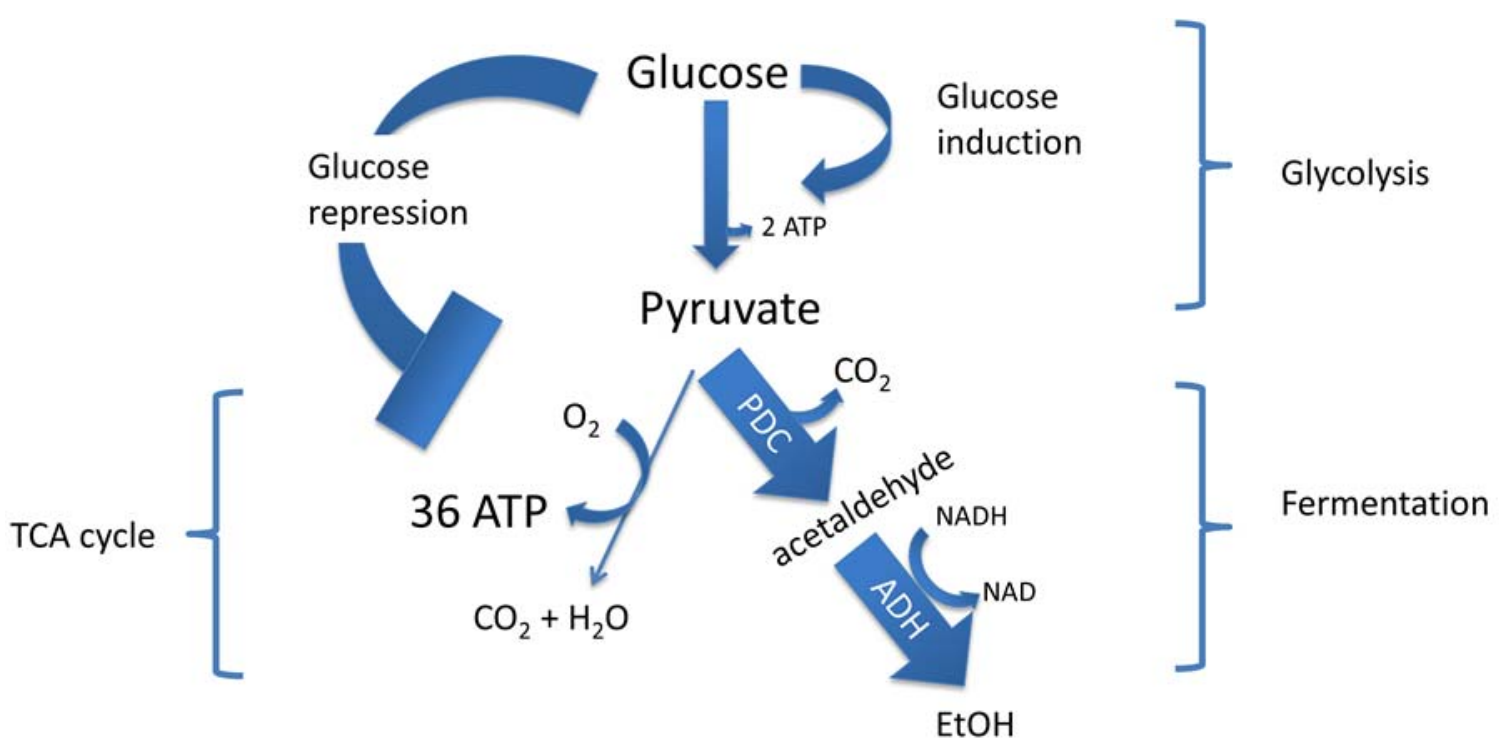

Figure 2 - A simplified diagram of glucose metabolism in S. cerevisiae. The diagram illustrates the metabolism of glucose towards ethanol synthesis via glycolysis and fermentation in glucose abundant conditions. The direction of glucose metabolism is supported by the upregulation of glycolytic genes and repression of genes involved in other pathways of utilization such as enzymes involved in the citric acid cycle. The copyrights of the original image (Johnston \& Kim, 2005) for modification were granted. 


\subsection{Glycolysis and fermentation}

\subsubsection{Glycolysis}

Glucose is metabolized to pyruvate (Lunt \& Vander Heiden, 2011) by glycolysis in

S. cerevisiae and in many other organisms as illustrated in Figure 3.

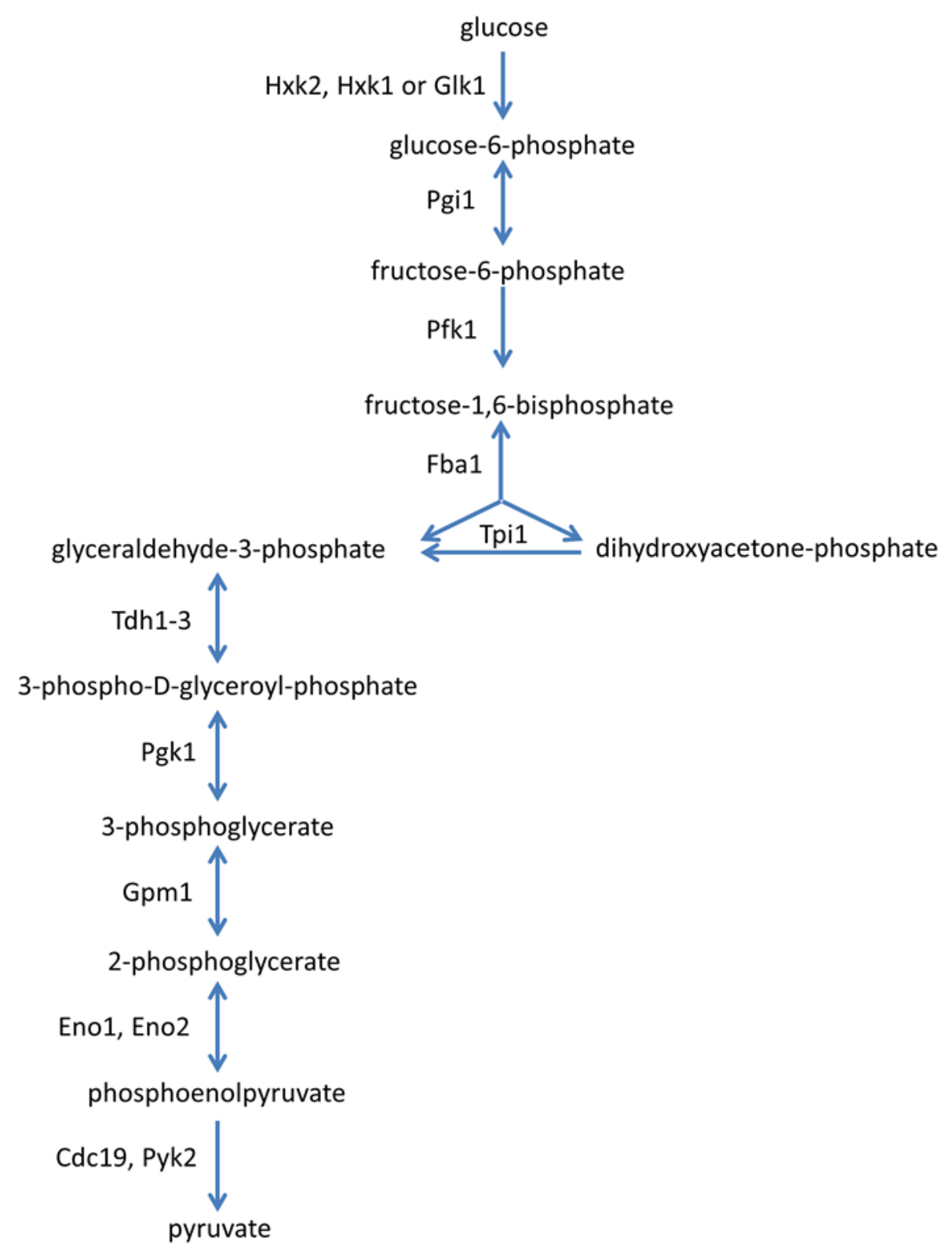

Figure 3 - Proteins and metabolites involved in glycolysis. Glucose is degraded to pyruvate through a series of reversible $(\uparrow)$ and irreversible $(\downarrow)$ enzyme-catalyzed reactions. Enzyme names are shown using the symbols described in the text.

In the first, irreversible, step of glycolysis hexose is phosphorylated by either hexokinases Hxk1 and Hxk2 or glucokinase Glk1 to glucose-6-phosphate. Hxk2 is the main kinase with preference for glucose, fructose or mannose as substrates 
(Bisson \& Fraenkel, 1983; De Winde et al., 1996). During growth on non-fermentable substrates transcript abundance for Hxk1 and Glk1 increases, while Hxk2 decreases (Rodriguez et al., 2001). In the second step of glycolysis, glucose-6-phosphate is reversibly converted to fructose-6-phosphate by phosphoglucose isomerase (Pgi1). The third reaction of glycolysis is phosphorylation of fructose-6-phosphate by phosphofructokinase (Pfk) to fructose-1,6-bisphosphate. Phosphofructokinase is a heterooctamer composed of four alpha and four beta subunits (Pfk1 and Pfk2 respectively). This enzyme is low abundance and has not been reported in gel-based proteomic studies without genetic manipulation (Boucherie et al., 1995).

The next reaction is the cleavage of fructose-1,6-bisphosphate to glyceraldehyde-3phosphate by fructose-1,6-bisphosphate aldolase (Fba1). The subsequent interconversion of glyceraldehyde-3-phosphate to dihydroxyacetone phosphate is catalyzed by triosephosphate isomerase (Tpi1). The succeeding steps of glycolysis result in conversion of the three-carbon intermediates to pyruvate, plus generation of ATP by substrate-level phosphorylation. Glyceraldehyde-3-phosphate is oxidized and phosphorylated by the homotetramer glyceraldehyde-3-phosphate dehydrogenase (Tdh). There are three isozymes derived from three corresponding genes (TDH1-3). Another reaction which results in the generation of ATP is the catalysis of the transfer of a phosphoryl group from 1,3-bisphosphoglycerate to ADP by phosphoglycerate kinase (Pgk1). Subsequently, phosphoglycerate mutase (Pgm1) converts 3-phosphoglycerate to 2-phosphoglycerate, which is then metabolized to phosphoglycerate by enolase (Eno). The two isozymes Eno1 and Eno2 are encoded by the respective genes ENO1 and ENO2. In glucose rich medium Eno2 protein is 20times more abundant than Eno1 but Eno1 increases to Eno2 levels in cells grown on ethanol or lactate (McAlister \& Holland, 1982). The last reaction of glycolysis is the irreversible catalysis of phosphoenolpyruvate to pyruvate by pyruvate kinase (Pyk). Pyk1 (Cdc19) is the primary enzyme. Its paralog, Pyk2, is repressed in glucose conditions (Boles et al., 1997).

\subsubsection{Fermentation}

During fermentation in $S$. cerevisiae pyruvate is primarily converted to ethanol using a two-step process. First, pyruvate is converted to acetaldehyde by pyruvate decarboxylase. There are three pyruvate decarboxylases (Pdc1, 5 and 6) encoded by 
different genes PDC1, PDC5 and PDC6. Pdc1 and Pdc5 are induced in the presence of glucose. Pdc6 is a low abundance isoform but increase when cells are gown on ethanol (Hohmann, 1991; Seeboth et al., 1990).

Following the decarboxylation of pyruvate, acetaldehyde is reduced to ethanol by alcohol dehydrogenase. There are seven alcohol dehydrogenase genes ADH1-7 (de Smidt et al., 2008). Two of these (ADH6 and ADH7) belong to the cinnamyl alcohol dehydrogenase (CAD) family and the remaining five are involved in ethanol metabolism (ADH1-5). The five dehydrogenases involved in ethanol metabolism are summarized in Table 1.

During growth on glucose Adh1 is the primary dehydrogenase responsible for the oxidation of acetaldehyde to ethanol. The 348 aa enzyme is localized in the cytoplasm. Adh2 is responsible for catalyzing the reverse reaction, reduction of ethanol to acetaldehyde. It is regulated by the transcription factor Adr1, which also has roles in glycerol metabolism. Expression of $A D H 2$ is repressed in glucose grown conditions (Stahlberg et al., 2008). Adh1 and Adh2 have greater than 90\% sequence similarity at the protein level and, due to only small differences in size and $\mathrm{p} I$ (Table 1), are expected to co-migrate on 2DE gels.

Adh3, 4 and 5 are also capable of catalyzing the oxidation of acetaldehyde but in more specific conditions. Of these, $A D H 3$ and $A D H 5$ are repressed in the presence of glucose (Young \& Pilgrim, 1985). ADH3 encodes an alcohol dehydrogenase which is localized to the mitochondrion (Wiesenfeld et al., 1975). Wiesenfeld et al. (1975) reported that sequence homology between Adh3 and Adh1 or Adh2 at the amino acid level was $79 \%$ and $80 \%$ respectively. Relatively little is known about the cytoplasmically localized Adh5 whose encoding gene, ADH5, was discovered upon sequencing of chromosome II (Feldmann et al., 1994). Smith et al. (2004) proposed that Adh5 was the sole enzyme for ethanol production in an ADH1 ADH3 double null mutant. Adh4 is localized to the mitochondrion like Adh3, but is not repressed in cells grown on glucose. The pioneers of Adh4 research were Paquin and Williamson (1986) and Walton et al. (1986). Early studies on Adh4 implied Adh4 was absent in the presence of Adh1. However, in 1999 Perrot et al. (1999) identified Adh4 in the presence of Adh1 and 2 using MAT a mating type yeast. 
Table 1 - The five S. cerevisiae Adh isoforms involved in ethanol metabolism. The information was derived from ExPASyhttp://www.expasy.org/. The ExPASy records indicate that there is MS evidence of protein for Adh 1 and 2, but that there is not MS evidence for Adh3-5 protein in S. cerevisiae.

\begin{tabular}{|c|c|c|c|c|c|c|}
\hline Adh & $\mathrm{kDa}$ & $\mathrm{pl}$ & $\begin{array}{l}\text { Number of } \\
\text { molecules } \\
\text { per cell in log } \\
\text { phase (from } \\
\text { ExPASy) }\end{array}$ & $\begin{array}{l}\text { Subcellular } \\
\text { localization }\end{array}$ & Function & $\begin{array}{l}\text { Role during } \\
\text { fermentation on } \\
\text { glucose }\end{array}$ \\
\hline 1 & 36.8 & 6.21 & Not recorded & Cytoplasm & Aldehyde $\rightarrow$ alcohol & Major activity \\
\hline 2 & 36.7 & 6.26 & 1620 & Cytoplasm & Alcohol $\rightarrow$ aldehyde & Glucose repressed \\
\hline 3 & 40.4 & 7.24 & 11600 & Mitochondrion & Aldehyde $\rightarrow$ alcohol & Glucose repressed \\
\hline 4 & 41.1 & 5.76 & 125 & Mitochondrion & Aldehyde $\rightarrow$ alcohol & $\begin{array}{l}\text { Second acting } \\
\text { aldehyde reducing } \\
\text { dehydrogenase }\end{array}$ \\
\hline 5 & 37.6 & 5.94 & 1310 & $\begin{array}{l}\text { Cytoplasm } \\
\text { nucleus }\end{array}$ & Aldehyde $\rightarrow$ alcohol & Glucose repressed \\
\hline
\end{tabular}




\subsection{Glycerol metabolism and gluconeogenesis}
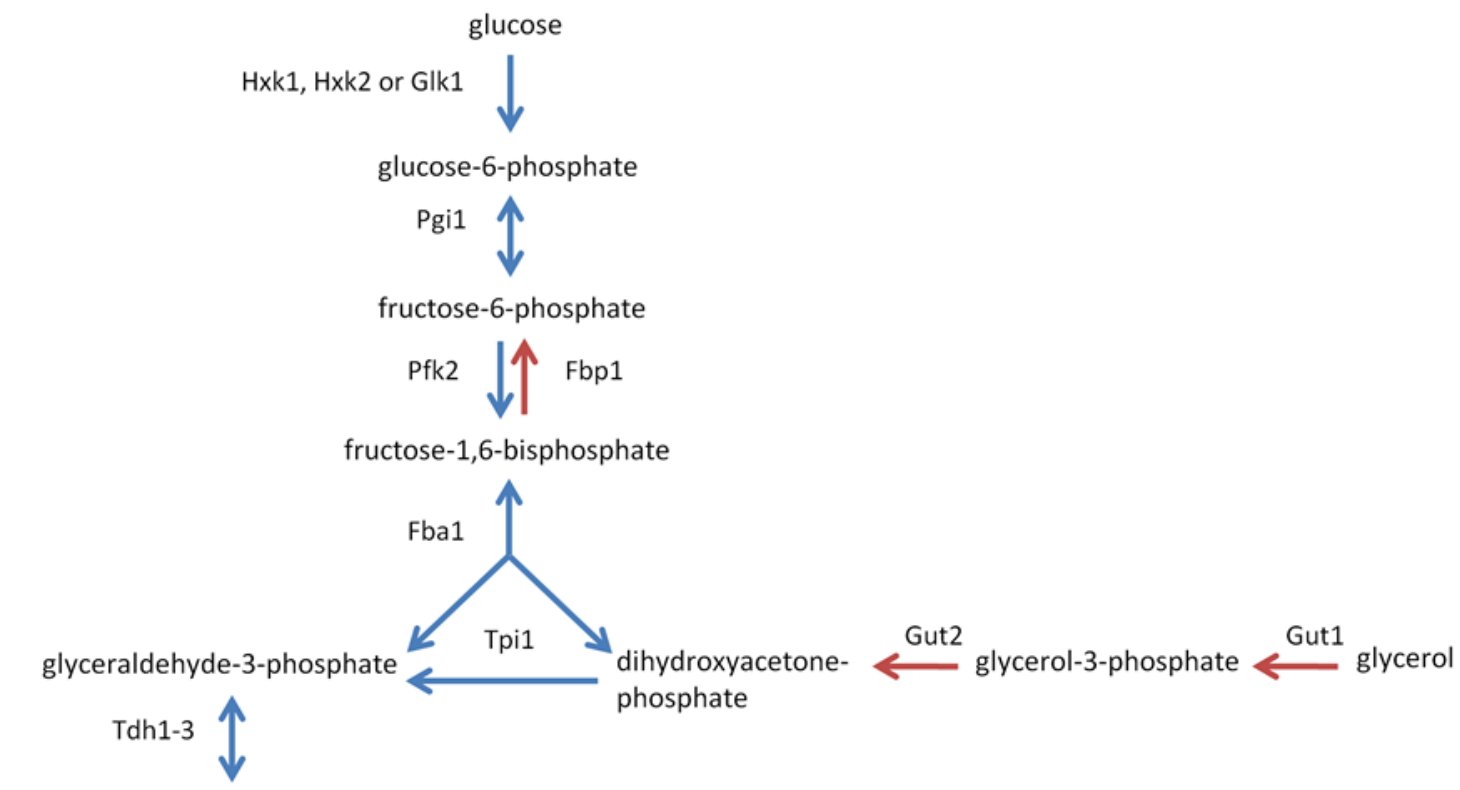

3-phospho-D-glyceroyl-phosphate

Pgk1 ^

3-phosphoglycerate

Gpm1

2-phosphoglycerate

Eno1, Eno2 ^

phosphoenolpyruvate

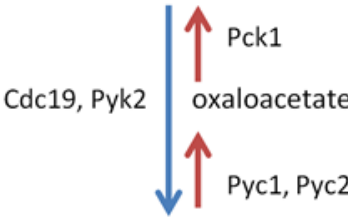

pyruvate

$$
\text { Pdc1, Pdc5 or Pdc6 }
$$

Figure 4 - Proteins and metabolites involved in glycerol metabolism,

gluconeogenesis/ glycolysis. Enzymes involved in glycerol metabolism $(\leftarrow)$ and gluconeogenesis $(\uparrow)$ /glycolysis $(\downarrow)$ are presented. Enzymes responsible for the catalysis of reversible gluconeogenic/ glycolytic reactions are represented by $\uparrow$. 


\subsubsection{Glycerol metabolism}

Utilization of glycerol by S. cerevisiae leads to entry into the glycolytic and gluconeogenic pathways. Glycerol is also a potential product of the metabolism of glucose. Two enzymes Gut1 (glycerol kinase) and Gut2 (glycerol-3-phosphate dehydrogenase) carry out the sequential reversible reactions converting glycerol to dihydroxyacetone phosphate, which is an intermediate of both glycolysis and gluconeogenesis (Figure 4). Gut1 is a cytoplasmic enzyme that phosphorylates glycerol to glycerol-3-phosphate. Glycerol-3-phosphate translocates to mitochondria where Gut2 catalyzes conversion to dihydroxyacetone phosphate.

Dihydroxyacetone phosphate is transported back into the cytoplasm where it enters the gluconeogenic/ glycolytic pathways. The genes of encoding both enzymes, GUT1 and GUT2 are repressed during fermentation of glucose (Sprague \& Cronan, 1977). The mediator of GUT1 is Adr1, which is also the transcriptional activator of ADH2 (Grauslund et al., 1999) .

\subsubsection{Gluconeogenesis}

Figure 4 also illustrates the reactions of glycolysis and gluconeogenesis showing the irreversible reactions that are common to both pathways and the irreversible reactions that are specific for one or the other of the two pathways. There are two irreversible reactions in glycolysis. Pfk1 and Pyk1 catalyze two of the glycolysis specific reactions. The corresponding irreversible steps of gluconeogenesis are catalyzed by fructose-1, 6-bisphosphatase (Fbp1) and a two-step reaction involving phosphoenolpyruvate carboxykinase (Pck1) and pyruvate carboxylase (Pyc1 or Pyc2). Pyc1 or its paralog Pyc2 converts pyruvate to oxaloacetate. In yeast this reaction occurs in the cytoplasm unlike mammals where the reaction occurs in the mitochondrion. Oxaloacetate is catalyzed to phosphophenol pyruvate by Pck1. The gluconeogenic enzyme Fbp1 converts fructose-1,6-bisphosphate to fructose-6phosphate.

\subsection{Regulation of glucose metabolism}

The concentration of glucose plays a crucial role in glucose metabolism. It has influential effects on gene repression and induction. When there are high concentrations of extracellular glucose, greater than 1\% (Yin et al., 2003), low affinity hexose transporter $(H X T)$ genes are expressed and allow glucose entry into the cell. 
Extracellular glucose concentrations as low as $0.2 \%$ cause the cells to respire (Guidi et al., 2010).

Two of the many pathways involved in glucose induction and repression are the Snf3-Rgt2 pathway required for glucose uptake by hexose transporters, and the Mig1-Snf1 pathway. Snf (sucrose nonfermenter) proteins affect transcription of a number of genes.

\subsubsection{Snf3-Rgt2 pathway}

The induction of hexose transporter genes is carried out by the Snf3-Rgt2 pathway. In high glucose conditions, glucose bound to low glucose affinity sensor Rgt2 (restores glucose transport), and Snf3 activates membrane bound yeast casein kinase 1 (Yck1) by a conformational change (Moriya \& Johnston, 2004) (Figure 5 top). The activated Yck1 phosphorylates Mth1 (MSN three homolog) and Std1 (suppressor of Tbp deletion) which are bound to the C-terminal cytoplasmic tails of the glucose receptors. Subsequently, phosphorylated Mth1 and Std1 are ubiquinated by the ubiquitin-ligase complex of Skp1 - Cul1 - F-box with Grr1 (SCFGrr1) (Moriya \& Johnston, 2004) and targets them for proteasome degradation. The transcriptional repressor Rgt1 losses its ability to bind DNA due to loss of Mth1, and Std1 (Kim et al., 2003), becomes hyperphosphorylated and translocates to the cytoplasm allowing transcription of HXT1 (Johnston \& Kim, 2005; Kim et al., 2003).

Whereas in low glucose conditions, intermediate and high glucose affinity transporters are induced to mediate glucose uptake (Figure 5 bottom) (Boles et al., 1997). This process involves the high glucose affinity glucose receptor, Snf3. The intracellular signal generated from glucose detection is still unclear. However it is known that SCFGrr1 (Li \& Johnston, 1997), Rgt1 and its co-repressors Tup1 and Ssn6, and Mth1 and Std1 (Lakshmanan et al., 2003) are involved in the transcriptional activation of intermediate and high affinity hexose transporters, HXT2, HXT3 and HXT4 (Flick et al., 2003; Ozcan \& Johnston, 1995).

\subsubsection{Mig1-Snf1 pathway}

The repression or activation of genes involved in glucose utilization other than glycolysis is controlled by the Mig1-Snf1 pathway (Figure 5 right) (Johnston, 1999).

The pathway involves Reg1-Glc7 protein phosphatase, Snf1 complex, and Mig1. The 
pathway depends on the activity of the Snf1 complex which is regulated by glucose (Jiang \& Carlson, 1996). In high glucose conditions, glucose is transported by Hxt1 and elevated intracellular glucose levels prevent Reg1-Glc7 from activating the Snf1 complex (Figure 5 top, right). The Snf1 complex has a catalytic (CD) and regulatory domain (RD). The catalytic domain is autoinhibited by binding to the regulatory domain resulting in an inactive Snf1 complex (Jiang \& Carlson, 1996). As a result, transcriptional repressor Mig1 and its co-repressors Tup1 and Ssn6 are able to repress genes associated with more efficient means of glucose utilization as well as high affinity transporters, HXT2, HXT3 and HXT4 (Gancedo, 1998).

In contrast, when glucose is low Snf4 is able to bind to the regulatory domain of Snf1 causing the release of the catalytic domain (Jiang \& Carlson, 1996) (Figure 5 bottom, left). The active Snf1 complex now has the ability to phosphorylate Mig1, which causes Mig1 to dissociate from its corepressors (Treitel et al., 1998). As a result Mig1, Tup1 and Ssn6 are unable to repress transcription. 

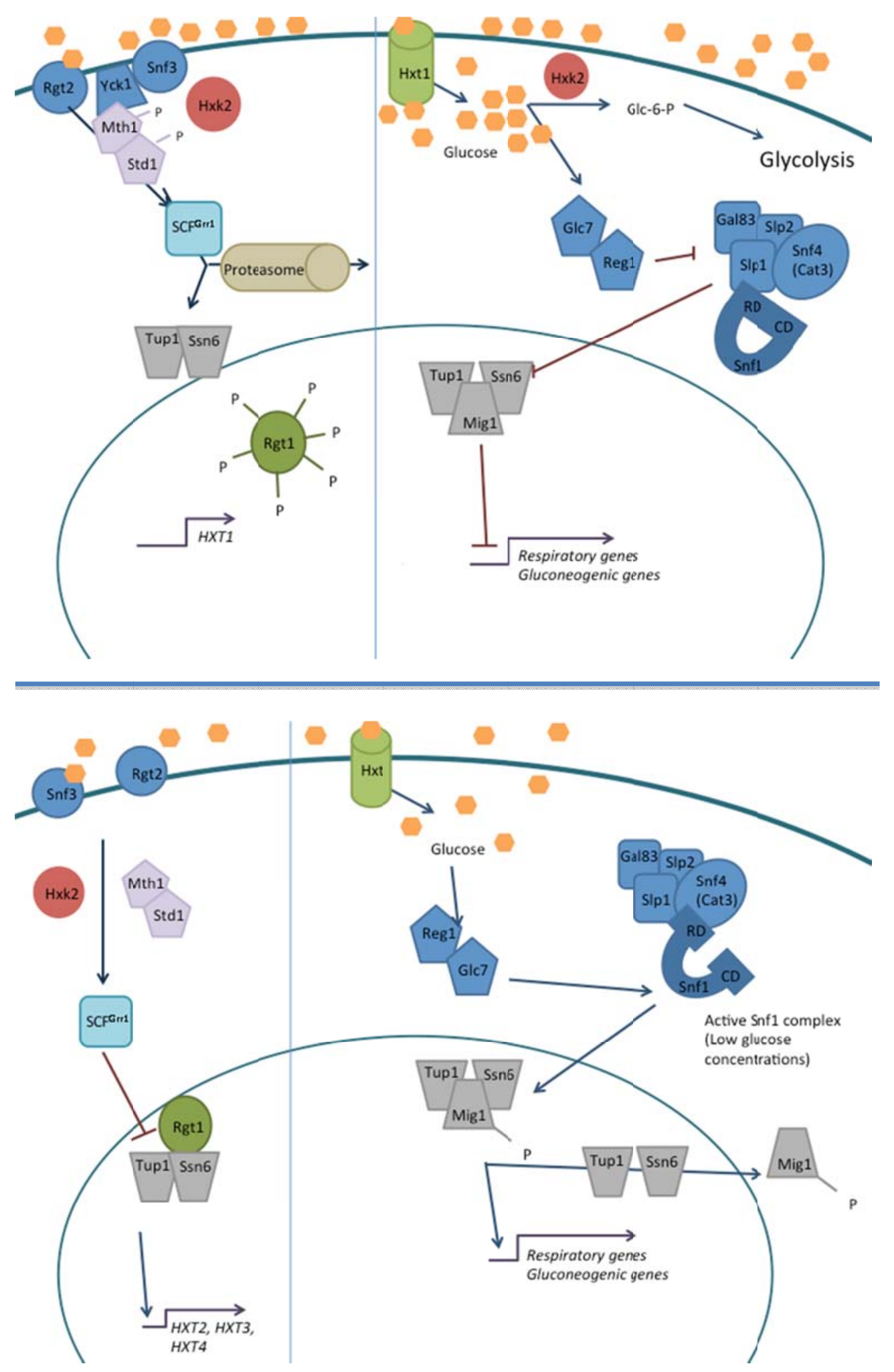

Figure 5 - The induction and repression of genes involved in the Snf3-Rgt2 (left) and Mig1-Snf1 (right) pathways of S. cerevisiae. The diagram shows cells grown in high (top) and low (bottom) glucose conditions. The above illustrations are modified diagrams from Gancedo (1998), Johnston and Kim (2005), and Rolland et al. (2002). The copyrights for the modifications of their images were approved. 


\subsection{Transcriptomic analysis of carbon substrate metabolism}

In addition to study of individual genes and proteins both transcript and proteome analysis have been used to examine metabolism in S. cerevisiae. The power of transcript analysis is based on the ability to measure the effects of many genes.

Oxidative metabolism and fermentation of carbon substrates have been extensively studied at the level of the transcriptome. A recent interest is towards transcript studies focusing on substrate transition to get a greater understanding of the adaptation process. Roberts and Hudson (2006) used microarrays to examine the transition of cells grown to early log phase in glucose to a medium containing a nonfermentable substrate of glycerol or ethanol. They found the upregulation of the following gene clusters 'respiration', 'carbohydrate and fatty acid metabolism', 'stress', 'endocytosis, actin and stress', and 'protein localization'. The following biological process clusters were down regulated, 'respiration - oxidative phosphorylation, mitochondrial electron transport chain', 'transport', 'membrane and sphingolipid metabolism', and 'stress, electron transport chain'.

Transcriptional work by Dikicioglu et al. (2011) examined the effects of cells grown in a glucose-limited culture to a pulse of glucose. In response to the addition of glucose they found significant changes in 372 gene transcripts. These were genes involved in the following biological processes 'carboxylic acid metabolism', 'amino acid metabolism' 'purine metabolism', 'glycolysis', 'oxidative phosphorylation', 'alcoholic catabolism' and 'energy-coupled proton transport'. Genes involved in glycolysis that were mentioned to be upregulated during this action were not an immediate response. Five genes associated with alcohol metabolism, PFK1, PFK2, ENO2, TKL1 and CTS1, were also upregulated.

\subsection{Proteomic analysis}

Proteomics complements measurements of mRNA transcripts through analysis of individual proteins. There is often a poor or only modest correlation between the amount of mRNA and the protein product. Wu et al. (2008) analyzed the relationship between transcriptome and proteome in S. cerevisiae. They concluded that protein degradation was a major factor affecting mRNA-protein ratios. Massoni et al. (2009) used pulse chase of $S$. cerevisiae strains grown in $\left[{ }^{35} \mathrm{~S}\right]$ methionine and $2 \mathrm{DE}$ analysis to examine changes in abundance of individual protein spots. Their study included 
detection of post-translational modifications that resulted in change of protein spot position on the 2D gels, and analysis of differences in protein turnover. Posttranslational modifications were identified by shift in $\mathrm{pI}$, in most cases towards the acidic end of the $\mathrm{pH}$ scale. They also found proteolytic products (fragments) of proteins that resulted in changes in abundance of protein isoforms. For example, a decrease of pyruvate decarboxylase was complemented by an increase in abundance of its fragments Pdc1f1 and Pdc1f2.

Analysis of the S. cerevisiae proteome using 2DE or gel-free LC MS/MS has been described in several reports from Matthias Mann's research group. Initially, Shevchenko et al. (1996) described methods for identification of protein spots excised from 2D gels, resulting in identification of 150 proteins using a combination of MALDI TOF MS mass fingerprinting and ESI LC MS/MS of tryptic digests. Advances in mass spectrometer design since that time have led to major enhancements in resolution and sensitivity so that over 4000 yeast proteins can now be identified using gel free LC MS/MS of yeast extracts (Nagaraj et al., 2012).

Several groups have used proteomics, with or without transcript analysis, to examine fermentative and oxidative metabolism in S. cerevisiae. Kolkman et al. (2005) compared the effects of glucose or ethanol-limitation on the transcriptome and 2DE proteome of cells grown under steady-state conditions in chemostat cultures. Protein identification by MALDI TOF MS or LC MS/MS found 44 proteins involved in central carbon metabolism including the functional categories glycolysis, pyruvate branch point, TCA cycle and gluconeogenesis and glyoxylate shunt. Fifteen proteins showed quantitative differences in abundance $(\mathrm{p} \leq 0.02)$ between ethanol or glucoselimited cells and a further two proteins (Hxk1, Adh1) were detected only during glucose-limitation compared to 12 proteins (mainly citric acid cycle and gluconeogenic enzymes) that were detected only during ethanol-limitation.

Glycolytic enzymes shared between the two conditions were Glk1, Fba1, Tpi1, Tdh2, Tdh3, Pgk1, Gpm1, Eno1 and Eno2.

Usaite et al. (2008) used LC MS/MS shotgun analysis of tryptic digests for comparison of wildtype and Snf1 protein kinase mutant strains grown aerobically under steady-state conditions. Approximately 2400 proteins were quantified using 
spectral counting and SILAC methods. The large increase in number of proteins detected compared with 2DE reflects the greater depth of analysis using gel-free MS methods although detection of processed protein fragments is not so straightforward. Approximately 15\% of the measured proteins, including carbohydrate metabolism enzymes, varied $(\mathrm{p} \leq 0.05)$ between the wildtype and mutant strains. Calculated differences in protein abundance were a 2.3-fold increase in Adh1 and a 5.3-fold decrease in Adh2 in a Snf1-deficient strain compared to the wildtype, suggesting a shift towards ethanol production when Snf1 was deficient. Bruckmann et al. (2009) used 2DE and transcript analysis to compare anaerobic and aerobic cultures grown in steady-state glucose-limited conditions. One hundred and ten identified protein spots, representing the products of 75 unique genes, differed by more than 2-fold between the cultures. The glycolytic enzymes Cdc19, Eno1, Hxk1, Pgk1, as well as proteins involved in pyruvate metabolism (Pdc1 and Adh1) were more abundant in anaerobic conditions. Changes in proteins specific to aerobic growth were associated with oxidative metabolism, including decreases in Adh2 and Ald4 and 6 for cells grown anaerobically. They also identified changes at the level of protein that were greater than predicted from transcripts.

Guidi et al. (2010) examined the metabolic adaptability of S. cerevisiae to three different concentrations of glucose. The three concentrations tested were $0.5 \%$ (low, glucose restriction), 2\% (control) and 20\% (excess). Proteins were separated by 2DE and abundances were measured using imaging of Coomassie stained gels, which is less accurate than DIGE. Twenty-one differentially expressed proteins were identified by MALDI mass fingerprinting. The abundance of some Pdc1, Pgk1, Eno2 and Tdh3 protein spots decreased in 0.5 and $20 \%$ glucose conditions compared to cells grown in $2 \%$ glucose. However, spots matching to the glycolytic enzymes Pdc1, Eno2 and Tdh3 increased in abundance at $20 \%$ glucose compared to control conditions. The analysis was complicated by detection of multiple protein spots for some of enzymes. For example, two protein spots matched to enolase 2 (Eno2). The most abundant form increased nearly 2 -fold in $20 \%$ glucose, while a less abundant form showed a 3.5 -fold increase in $2 \%$ compared to $0.5 \%$ glucose. Of two detected Adh1 protein spots, the most abundant did not show major change between $0.5 \%$ and $2 \%$ glucose but increased nearly 3-fold in 20\% glucose. Measurement of glucose 
use and alcohol production indicated complete conversion to ethanol at $0.5 \%$ glucose, and $63 \%$ and $38 \%$ conversion respectively at $2 \%$ and $20 \%$ glucose.

Transcript and proteome changes associated with nutrient limitation were examined by Stephen Oliver's research group Gutteridge et al. (2010). Carbon-limitation was carried out by a shift from $2.1 \%$ to $0.25 \%$ glucose in the medium. iTRAQ with LC MS/MS of tryptic digests was used for the proteomics analysis. Proteins that changed more than two-fold in abundance in glucose-limited medium included increases in hexokinase Hxk1 and aldehyde dehydrogenases Ald 1 and 3, and decreases of the hexose transporter Hxt3, and alcohol dehydrogenase 4 (Adh4).

Huang et al. (2012) used LC MS/MS of tryptic digests to compare the early- mid- and late-exponential phase $(22.5,33$ and $44 \mathrm{~h})$ proteins of $S$. cerevisiae grown in shake flask cultures with initial $4 \%$ glucose. Ethanol was the major metabolic product after $24 \mathrm{~h}$, glycerol and acetic acid were not detected. Of the total 1389 proteins identified (representing 1331 unique genes) there were differences in protein abundance between stages of the growth phase, including lower amounts of ribosomal proteins associated with cell proliferation towards the end of the growth phase. Adh1 and the citric acid cycle enzymes were represented at all three stages of growth indicating capacity both for fermentation of glucose to ethanol and oxidative metabolism. Most recently, Stobaugh et al. (2013) used LC MS/MS to compare the proteomes of S. cerevisiae grown on glucose or glycerol in shake flasks. Their emphasis was on comparison of fractionation by anion-exchange or reversed-phase chromatography of proteins prior to LC MS/MS of tryptic digests. Protein abundances were quantified using spectral counting, carbon substrate related changes were expected for 1.5 -fold differences in protein abundance at $\mathrm{p} \leq 0.05$. There were differences in the numbers of proteins detected and quantified between the two prefractionation protocols, however, the general conclusion was that the abundances of several glycolytic enzymes did not differ between growth on glucose or glycerol. Their results are summarized in Figure 6. In general, growth on glucose (dextrose) resulted in higher abundance of hexokinase B (Hxk2) and enzymes for synthesis of glycerol from dihydroxyacetone phosphate. Growth on glycerol favored production of hexokinase A (Hxk1) and glucokinase (Glk1), and enzymes involved in 
gluconeogenesis, the use of glycerol and oxidative citric acid cycle activity. Although the amount of Adh1, that catalyzes synthesis of ethanol, did not vary significantly between growth on glucose or glycerol, use of glycerol as a substrate resulted in greater abundance of Adh2 and aldehyde dehydrogenases that catalyze the two-step pathway for synthesis of acetate from ethanol. The gluconeogenic enzyme fructose1,6-biphosphatase was more abundant using glycerol as a substrate in samples prepared using reversed-phase chromatography for protein fractionation, but this enzyme was not detected using ion-exchange workup. Overall, the results illustrate the effect of carbon substrate on the abundances of proteins involved in pathways of carbon metabolism, and the importance of sample preparation protocols for protein detection and quantification. 
(a) Anion-Exchange Pre-fractionation

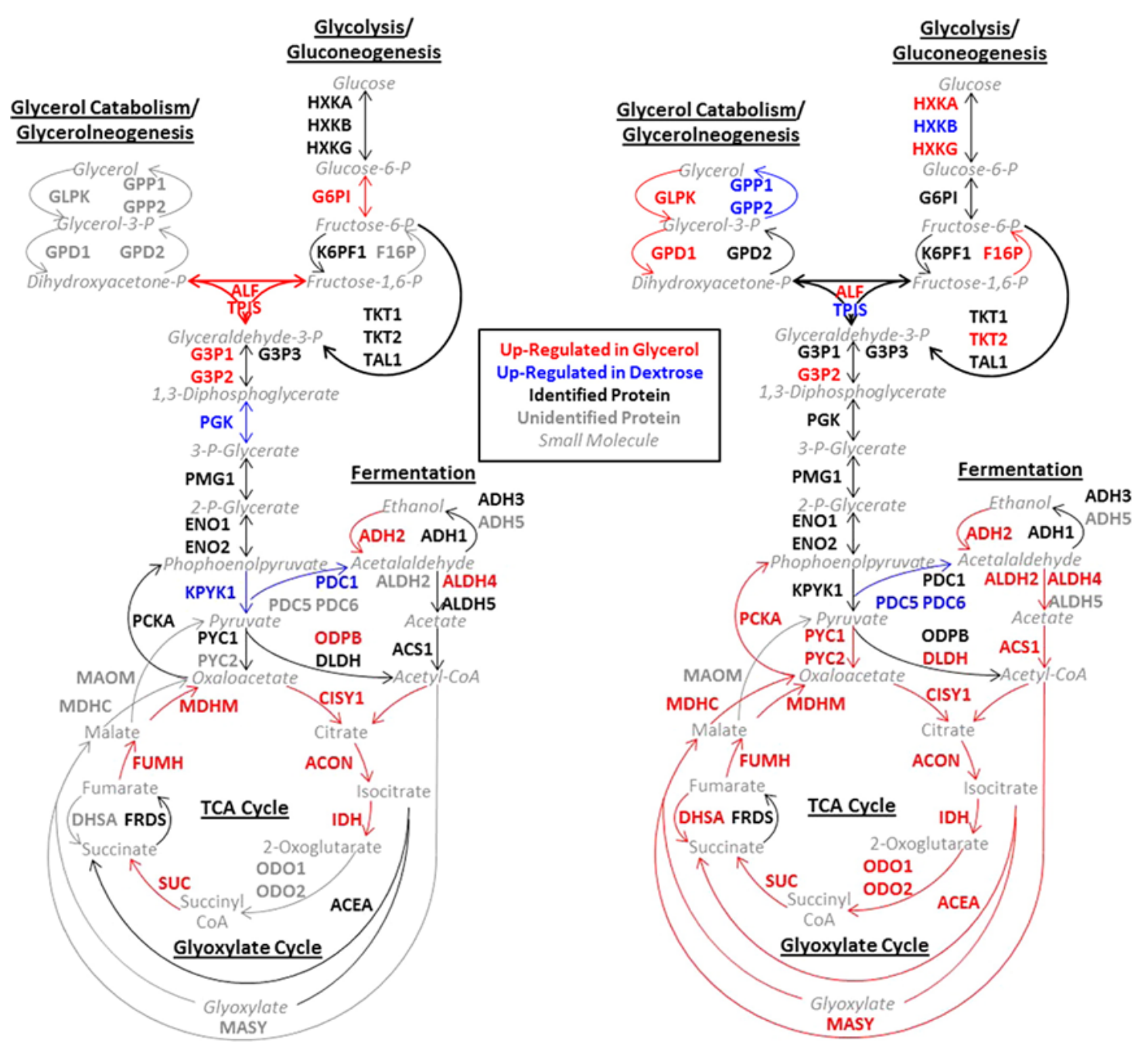

Figure 6 - Proteomic analysis of S. cerevisiae grown in glucose (dextrose) or glycerol based media by Stobaugh et al. (2013). Samples were pre-fractionated by anionexchange (a) or reversed-phase (b) chromatography before LC MS/MS.

Prefractionation of proteins by reversed-phase chromatography recovered more proteins than anion-exchange chromatography. Glycolytic proteins were found in both substrate conditions and between the two techniques. The copyrights to use this diagram were granted.

\subsection{Goal of this research}

The overall goal of this project was to examine the extent to which the abundances of enzymes involved in glucose metabolism varied between conditions that favored fermentation or respiration. Two-dimensional-DIGE was used for the comparison of protein abundances as many of the relevant enzymes are relatively high abundance and can be detected on 2D gels. One qualification for use of 2DE is that hydrophobic 
proteins including membrane transporters are not soluble during the initial focusing step and are therefore not detected. The emphasis of the project was therefore on detection of soluble proteins including the enzymes of carbohydrate metabolism. The four specific aims were to:

- Set up experimental conditions for extraction and separation of S. cerevisiae proteins

- Create a database of proteins identified by MALDI TOF/TOF MS of tryptic digests of proteins excised from 2DE gels

- Examine substrate conditions that favor fermentation or oxidation of the carbon source

- Use 2D-DIGE to compare the enzyme abundances between conditions that favor fermentation or oxidative metabolism of the carbon source

Growth of S. cerevisiae in glucose or glycerol in shake flask cultures was chosen for the DIGE analysis. At the time this decision was made there were no reported proteomic comparisons using these two substrates, although there is now the shotgun LC MS/MS analysis of Stobaugh et al. (2013). This Thesis is therefore the first 2DE study of protein variation using these growth conditions. 


\section{Methods}

\subsection{Yeast strains and storage}

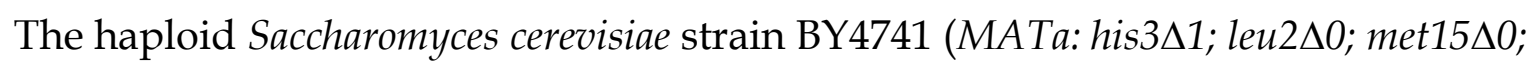
ura $3 \Delta 0$ ) was used in this project. The strain was stored in $15 \%$ glycerol and yeast peptone (YP) media at $-80^{\circ} \mathrm{C}$ for long-term preservation. Single colonies were generated by streaking out cells on an YPD agar plate (1\% yeast extract, $2 \%$ peptone, $2 \% \mathrm{D}$-glucose) using aseptic technique, then incubated at $30^{\circ} \mathrm{C}$ for 2 days, and kept at $4^{\circ} \mathrm{C}$ for up to 3 months.

\subsection{Comparative growth experiments}

To analyze the growth of BY4741 in fermentative and non-fermentative states cells were grown in (a) varying glucose concentrations with Synthetic Complete (SC) media and (b) a high glucose concentration versus glycerol supplemented SC media. The growth conditions for the two experiments are shown in Figure 7. For the glucose experiment, cultures supplemented with $0.2 \%$ (low), $0.5 \%$ (medium) or $2 \%$ (high) glucose and SC media were set up from precultured $2 \%$ glucose cultures in stationary phase (seeding culture). The comparative analysis of BY4741 grown in SC media supplemented with glycerol or glucose is described as the glycerol versus glucose experiment. Cultures of BY4741 supplemented with 3\% glycerol (3\% G2) or $2 \%$ glucose $(2 \% \mathrm{D})$ were inoculated from previously grown stationary phase cultures of $3 \%$ glycerol (3\% G1) in SC media. The growth of BY 4741 using glycerol is commonly supplemented with ethanol. However, the addition of ethanol was excluded in order to simplify the measurement of ethanol production.

\subsection{Growth conditions}

Cells were grown in $25 \mathrm{~mL}$ of SC media supplemented with $2 \%$ glucose or $3 \%$ glycerol at $30^{\circ} \mathrm{C}$, with shaking at $250 \mathrm{rpm}$ (Bioline, NSW, Australia) as shown in Figure 7. Cultures were inoculated with $6.5 \times 10^{5}$ cells from previously grown stationary phase cultures, in conical flasks with a maximum depth of $1 \mathrm{~cm}$ medium to ensure aeration. 


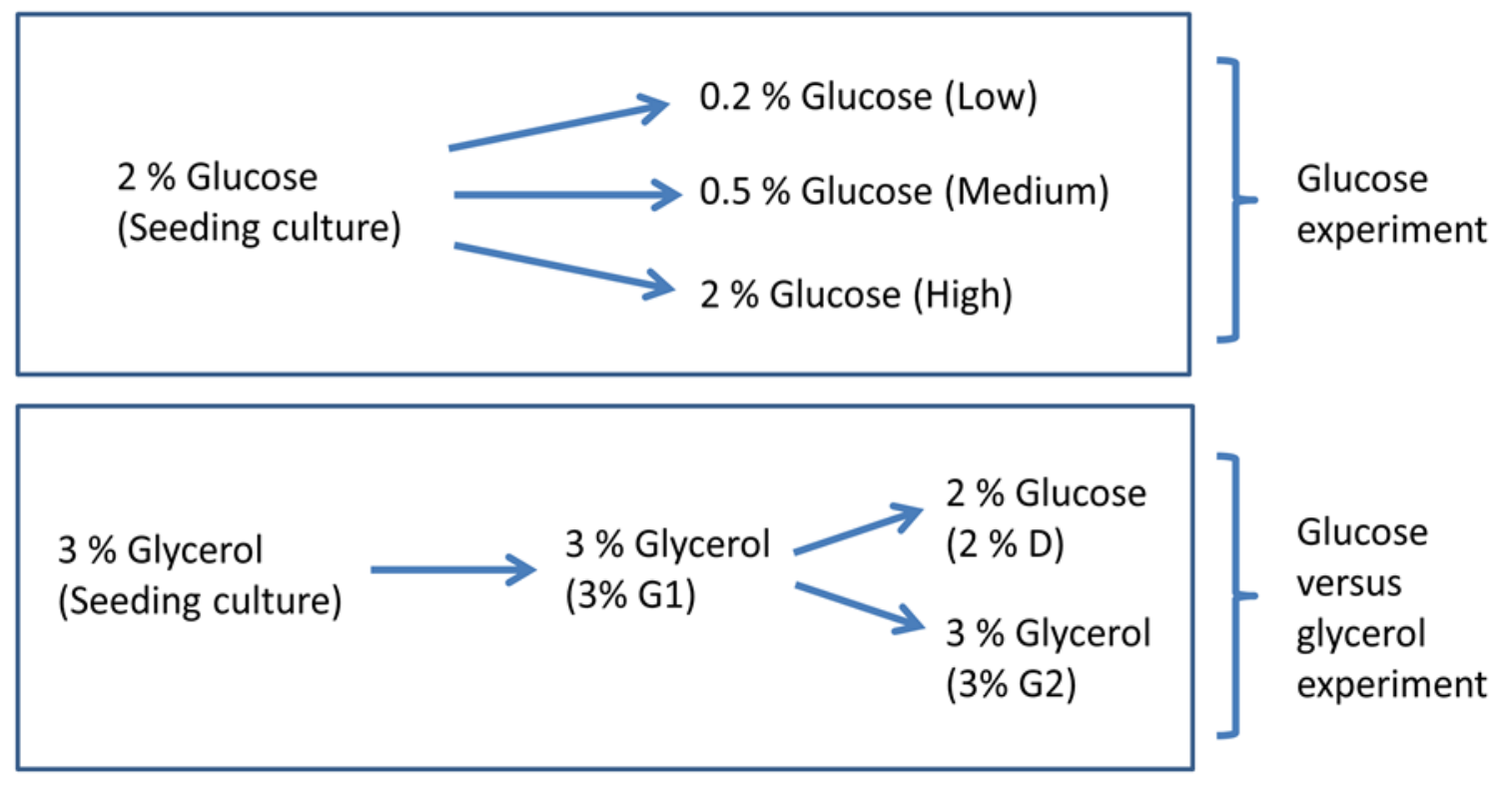

Figure 7 - Growth conditions of BY4741 for the analysis of fermentative and oxidative metabolism. Cells were grown in SC media supplemented with different glucose concentrations (top) or 3\% glycerol vs. $2 \%$ glucose (bottom).

\subsection{Growth Curves}

Three $10 \mathrm{~mL}$ cultures of BY4741 in SC media with 2\% glucose or 3\% glycerol were prepared. The point at which cultures were inoculated with cells was time zero. An aliquot of each culture was taken, diluted 10X and the optical density (OD) measured at $600 \mathrm{~nm}$ using a Cary 300 Bio UV-Visible Spectrophotometer (Varian, VIC, Australia). The first measurement was taken at time zero. For glucose supplemented growth, the next measurement was taken at $\mathrm{t}=4.5 \mathrm{~h}$ then every 1-1.5 $\mathrm{h}$ thereafter. For glycerol supplemented cultures, the next measurements were taken at $\mathrm{t}=12 \mathrm{~h}$ and $\mathrm{t}=15 \mathrm{~h}$ followed by a $9 \mathrm{~h}$ interval. From herein, time points were every $3 \mathrm{~h}$ for $15 \mathrm{~h}$ followed by a $9 \mathrm{~h}$ interval with the final measurement at $\mathrm{t}=96 \mathrm{~h}$.

\subsection{Harvesting yeast cultures}

Cells were collected at $\mathrm{OD}_{600}=0.5$ and were centrifuged using an Eppendorf Centrifuge 5810 (Hamburg, Germany) at 4,000 rpm for $5 \mathrm{~min}$ at $4^{\circ} \mathrm{C}$. The culture supernatant was removed and stored at $-80^{\circ} \mathrm{C}$ for glucose and ethanol analysis. The cells were washed three times in $\mathrm{ddH}_{2} \mathrm{O}$ followed by centrifugation at 13,000 rpm, at $25^{\circ} \mathrm{C}$ for 5 min using a Beckman Coulter Microfuge ${ }^{\circledR 16}$ Centrifuge (Krefeld, Germany). The third wash had an extra addition of Complete Mini EDTA-free 
Protease Inhibitor (1:100 w/v) (Roche, Mannheim, Germany). The yeast cells were stored at $-80^{\circ} \mathrm{C}$ until they were lysed for protein extraction.

\subsection{Protein extraction from cells}

Two protein extraction methods were explored for proteomic analysis of BY4741. First, a Yeast Protein Extraction Buffer Kit from GE Healthcare (Uppsala, Sweden) was used. Harvested yeast cells were washed two times by the addition of 5X the volume of Yeast Suspension Buffer, mixed then centrifuged at $13,000 \mathrm{rpm}$ at $4^{\circ} \mathrm{C}$ for $5 \mathrm{~min}$. The supernatant was discarded after centrifugation. Cells were lysed in $2 X$ the volume of the cell pellet with Yeast Protein Extraction Buffer. Protease inhibitor $(1: 100 \mathrm{w} / \mathrm{v})$ was added, mixed then incubated on ice for $30 \mathrm{~min}$. Cells were briefly incubated at $37^{\circ} \mathrm{C}$ for $2 \mathrm{~min}$ then centrifuged at $13,000 \mathrm{rpm}$ for $30 \mathrm{~min}$ at $4^{\circ} \mathrm{C}$. The supernatant was collected and stored at $-80^{\circ} \mathrm{C}$. The remaining cell pellet was discarded.

The second method used lysis buffer (4\% w/v CHAPS, 2 M thiourea, $7 \mathrm{M}$ urea, $30 \mathrm{mM}$ Tris $\mathrm{pH}$ 8.8) and white quartz sand (Sigma-Aldrich, St. Louis, MO). Onetimes the volume of lysis buffer was added to the cell pellet then ground in a microcentrifuge tube for $60 \mathrm{sec}$ with quartz sand using a mini pestle (GE Healthcare). Following cell grinding, cells were vortexed for $15 \mathrm{~min}$ at $4^{\circ} \mathrm{C}$ and centrifuged at $13,000 \mathrm{rpm}$ at $4^{\circ} \mathrm{C}$ for $5 \mathrm{~min}$. The supernatant was collected and stored at $-20^{\circ} \mathrm{C}$. The remaining cell pellet was discarded.

\subsection{One-dimensional SDS PAGE}

One-dimensional SDS PAGE was used for initial examination of the resulting cell lysates. The gel electrophoresis running buffer (1X) was prepared by mixing $760 \mathrm{~mL}$ of $\mathrm{ddH}_{2} \mathrm{O}$ and $40 \mathrm{~mL}$ of $\mathrm{NuPAGE}^{\circledR}$ MOPS SDS running buffer (20X) (Invitrogen, Carlsbad, CA). A 10 or 12 well NuPAGE ${ }^{\circledR} 4-12 \%$ Novex Bis-Tris Zoom ${ }^{\mathrm{TM}} 1.0$ mm gel (Invitrogen) was rinsed in $\mathrm{ddH}_{2} \mathrm{O}$ and assembled in an XCellSureLock ${ }^{\mathrm{TM}}$ Novex Mini-Cell electrophoresis system (Invitrogen). Both the inner and outer chambers were filled with the $1 \mathrm{X}$ running buffer, and $500 \mu \mathrm{L}$ of NuPAGE ${ }^{\circledR}$ Antioxidant (Invitrogen) was added to the inner chamber. Each protein sample $(1 \mu \mathrm{L})$ was mixed with $2.5 \mu \mathrm{L}$ of protein denaturant, 4 X NuPAGE ${ }^{\circledR}$ LDS Sample Buffer (Invitrogen), and $1 \mu \mathrm{L}$ of $10 \mathrm{X}$ NuPAGE ${ }^{\circledR}$ Sample Reducing Agent (Invitrogen). These samples 
were centrifuged $\left(5 \mathrm{~min}, 25^{\circ} \mathrm{C}, 13,000 \mathrm{rpm}\right)$ and heated at $70^{\circ} \mathrm{C}$ in an Ori-Block ${ }^{\circledR} \mathrm{OB}-1$ heat block (Techne, Cambridge, England) for $10 \mathrm{~min}$. Samples were then loaded into separate lanes of the gel. Either Mark ${ }^{12}$ (Invitrogen) or Rainbow 851 (GE Healthcare) was used as a protein standard and also loaded into a well. The gel was electrophoresed at $200 \mathrm{~V}$ for 55 min using an Electrophoresis Power Supply-EPS 301 (GE Healthcare).

\subsection{Gel fixing, staining and scanning}

Following electrophoresis, proteins were fixed by placing gels in $50 \% \mathrm{v} / \mathrm{v}$ ethanol, $3 \% \mathrm{v} / \mathrm{v}$ phosphoric acid for $30 \mathrm{~min}$ with shaking at $15 \mathrm{rpm}$ on a Labnet Gyrotwister (Woodbridge, NJ). The gels were rinsed three times in $\mathrm{ddH}_{2} \mathrm{O}$ for $30 \mathrm{~min}$ and transferred to $17 \% \mathrm{w} / \mathrm{v}$ ammonium sulfate, $34 \% \mathrm{v} / \mathrm{v}$ methanol, $3 \% \mathrm{v} / \mathrm{v}$ phosphoric acid. Gels were left in this solution for at least $60 \mathrm{~min}$ before the addition of Coomassie (CBB G-250) (Biorad, Hercules, CA). The gels were left in the staining solution for 2 days, and then washed three times in $\mathrm{ddH}_{2} \mathrm{O}$ for 30 min each to remove excess CBB G-250. Washed gels were scanned at 12 bits per pixel with a $50 \mu \mathrm{m}$ pixel size using a Personal Densitometer SI (Molecular Dynamics, Sunnyvale, $\mathrm{CA}$ ), and the gel images were viewed using ImageQuant ${ }^{\mathrm{TM}}$ software (Version 5.2, Molecular Dynamics). Images were saved as .gel files.

\subsection{Protein concentration}

The protein concentration of each cell lysate was measured using a GE Healthcare 2D-Quant kit. A standard curve was generated with duplicates of 0, 4, 6, 12 and $30 \mu \mathrm{g}$ using BSA. Aliquots of $2 \mu \mathrm{L}$ of each protein sample were tested in duplicate. First, proteins in the lysates and standard curve were precipitated by the addition of $500 \mu \mathrm{L}$ 2D-Quant Precipitant, vortexed then incubated at room temperature for 3 min. Following this, $500 \mu \mathrm{L}$ of Co-precipitant was added and mixed by inverting the microcentrifuge tubes. All samples were centrifuged at 13,000 rpm for $5 \mathrm{~min}$ at room temperature. The supernatant was discarded immediately, followed by a second period of centrifugation for $60 \mathrm{sec}$. The supernatant was decanted. To each protein pellet $500 \mu \mathrm{L}$ of Copper Solution was added then vortexed. The addition of $1 \mathrm{~mL}$ of Working Colour Reagent was followed by an incubation period of 15-20 min at room temperature. The absorbance was measured at $480 \mathrm{~nm}$ using water as the blank. 


\subsection{Protein precipitation}

Proteins in cell lysates were precipitated to remove unwanted cellular debris for better separation of proteins during electrophoresis and/or to concentrate samples. A ProteoExtract ${ }^{\circledR}($ Calbiochem, La Jolla, CA) protein precipitation kit was employed. The precipitant was added to the protein samples and left at $-20^{\circ} \mathrm{C}$ for at least $30 \mathrm{~min}$. The mixture was centrifuged for $5 \mathrm{~min}$ at room temperature and the supernatant was discarded. The protein pellet was washed twice in the wash solution and centrifuged, the supernatant was discarded between washes. The pellet was left to dry in a laminar flow workstation for at least $30 \mathrm{~min}$ before the addition of rehydration buffer or lysis buffer.

\subsection{Two-Dimensional Electrophoresis}

\subsubsection{First dimension}

Three $\mathrm{pH}$ ranges were examined; a broad range $\mathrm{pH}$ 3-11 non-linear (3-11NL), an acidic range $\mathrm{pH} 4-7$ and a basic range $\mathrm{pH}$ 6-11. Two methods of sample application were used, passive rehydration and cup loading. Sample application to $\mathrm{pH}$ 4-7 IPG strips was tested by passive rehydration and cup loading at the cathode. The $\mathrm{pH} 3-$ 11 NL strips required passive rehydration of the samples. The rehydration buffer complemented the $\mathrm{pI}$ of the IPG strip used i.e. $\mathrm{pH}$ 4-7 rehydration buffer was used for pH 4-7 IPG strips. All Immobiline ${ }^{\mathrm{TM}}$ DryStrip gels (pI 4-7, 6-11 and 3-11 NL), IPG buffers, reswelling tray and all components of the Multiphor II system (paper wicks, cups, electrodes, tank and power supply) were from GE Healthcare.

\subsubsection{Sample preparation for passive rehydration}

To protein pellets for passive rehydration, $125 \mu \mathrm{L}$ rehydration buffer $(7 \mathrm{M}$ urea, $2 \mathrm{M}$ thiourea, 4\% w/v CHAPS, 2\% v/v IPG buffer (GE Healthcare), 2\% w/v DTT (Merck) was added. This was left for $15 \mathrm{~min}$ before the sample was centrifuged. The sample was distributed over a $7 \mathrm{~cm}$ area in a well of an Immobiline ${ }^{\mathrm{TM}}$ DryStrip Reswelling Tray, and an IPG strip was placed gel side down over the sample. This was covered with $3 \mathrm{~mL}$ of Plus One DryStrip Cover Oil (GE Healthcare) and left overnight.

\subsubsection{Sample preparation for cup loading}

The preparation of samples for cup loading at the cathode or anode utilized the same protocol with the exception of the rehydration buffer. The rehydration buffer for $\mathrm{pH}$ 6-11 IPG strips contained $2 \mathrm{M}$ thiourea, $7 \mathrm{M}$ urea, 2.5\% w/v DTT, 2\% w/v CHAPS, 
0.2\% v/v pH 6-11 IPG buffer, 10\% v/v isopropanol (Merck), 5\% v/v glycerol. The protein pellet was reconstituted in $100 \mu \mathrm{L}$ of rehydration buffer. This was left for 15 min then centrifuged, and left overnight.

\subsubsection{Isoelectric focusing using a Multiphor II system}

For cup loaded samples, IPG strips were passively rehydrated the night before use, in $125 \mu \mathrm{L}$ of rehydration buffer, see section 2.11.2. Rehydrated IPG strips were placed gel side up in a Mulitphor II IEF tank. Two paper wicks were soaked in $500 \mu \mathrm{L}$ of $\mathrm{ddH}_{2} \mathrm{O}$ and placed over each end of the IPG strips. Electrodes were placed over the paper wicks. For cup loaded samples, cups were centred over the IPG strips before the tank was filled with Ondina oil (Shell, VIC, Australia). Cups were placed at the cathode or anode for focusing of $\mathrm{pH} 4-7$ or $\mathrm{pH}$ 6-11 IPG strips respectively. For pH 6-11 IPG strips one paper wick was soaked in $500 \mu \mathrm{L}$ of $\mathrm{pH}$ 6-11 rehydration buffer and placed at the cathode end. IPG strips were electrophoresed as stated in Table 2 using an Electrophoresis Power Supply-EPS 3500 XL.

Table 2 - Settings of the Multiphor II system for isoelectric focusing using $\mathrm{pH}$ 3-11 NL, 4-7 or 6-11 IPG strips.

\begin{tabular}{|c|c|c|c|}
\cline { 3 - 4 } \multicolumn{2}{c|}{} & \multicolumn{2}{c|}{ Time (h:m) } \\
\hline Step & Voltage & $\mathrm{pH} \mathrm{4-7} \mathrm{and} \mathrm{3-11NL}$ & $\mathrm{pH} 6-11$ \\
\hline 1 & 200 & $0: 01$ & $0: 01$ \\
\hline 2 & 3500 & $1: 30$ & $1: 30$ \\
\hline 3 & 3500 & $1: 30$ & $1: 05$ \\
\hline
\end{tabular}

\subsubsection{Second dimension - SDS PAGE}

Prior to the second dimension of 2DE, IPG strips were reduced in $1 \% \mathrm{w} / \mathrm{v}$ DTT then subjected to alkylation (2.5\% w/v IAA) in equilibration buffer (50 mM Tris $\mathrm{pH} 8.8$, $6 \mathrm{M}$ urea, 30\% v/v glycerol, 2\% w/v SDS), 15 min per incubation on a Platform Rocker (Bioline). The electrophoresis tank was prepared as described in section 2.7. The IPG strip was rinsed in the inner chamber, cut to fit within the well, and placed into the IPG well of a NuPAGE ${ }^{\circledR} 4-12 \%$ Novex Bis-Tris Zoom ${ }^{\mathrm{TM}} 1.0 \mathrm{~mm}$ IPG well gel. For reference purposes the anodic end of the IPG strip was placed closest to the 
ladder lane. The gel was then electrophoresed at $120 \mathrm{~V}$ for $115 \mathrm{~min}$. Gels were fixed, stained and scanned as described in section 2.8 .

\subsection{Protein spot picking, destaining of protein spots and trypsin digestion}

Protein spots were manually excised from gels using a spot picker (OneTouch Plus Spot/Band picker PDM1.5, The Gel Company, San Francisco, CA). Each gel plug was placed into a separate well of a 96 well v-bottomed plate with $100 \mu \mu \mathrm{L}$ of $20 \mathrm{mM}$ ammonium bicarbonate and left overnight at $4^{\circ} \mathrm{C}$. An Ettan digester (GE Healthcare) was used for protein digestion. All solutions were made fresh and filtered through $0.2 \mu \mathrm{m}$ membrane (Merck Millipore, Darmstadt, Germany). The digester software (version 1.10) method had a 3 phase wash cycle using $50 \mathrm{mM}$ ammonium bicarbonate, high grade methanol (Merck): $\mathrm{ddH}_{2} \mathrm{O} 1: 1 \mathrm{v} / \mathrm{v}$, followed by a drying period of at least $60 \mathrm{~min}$. After the drying cycle $50 \mathrm{ng}$ of modified sequencing grade trypsin (Roche) per well was added in $20 \mathrm{mM}$ ammonium bicarbonate to cleave proteins into peptides. The peptides were extracted from the gel plugs in $0.1 \% \mathrm{v} / \mathrm{v}$ TFA (Fluka), ACN (Merck): $\mathrm{ddH}_{2} \mathrm{O} 1: 1 \mathrm{v} / \mathrm{v}$ and transferred to a new 96 well vbottomed plate and left to dry overnight.

\subsection{Preparation of samples for MALDI MS/MS}

Digested peptides were mixed with fresh CHCA matrix solution $(10 \mathrm{mg} / \mathrm{mL}$ CHCA (Sigma-Aldrich) in 0.25\% v/v TFA. ACN: ddH $\mathrm{H}_{2} \mathrm{O} 1: 1 \mathrm{v} / \mathrm{v}$ ) and spotted onto MALDI plates. For internal calibration of masses, $0.7 \mu \mathrm{L}$ of Calibration Mixture 2 (Calmix 2) was added to the fresh matrix solution. Calmix 2 contains angiotensin I, ACTH (clip 1-17), ACTH (clip 18-39) and ACTH (clip 7-38) with the monoisotopic masses of $1,296.68,2,093.08,2,465.19$ and 3,657.92. The digested peptides were mixed in CHCA matrix with Calmix 2 before spotting. For external calibration of masses aliquots of Calmix 2 in CHCA matrix were spotted separately on MALDI plates.

\subsection{MALDI TOF/TOF MS}

An AB SCIEX 5800 mass spectrometer was used to acquire mass spectra for protein identification. Before data collection, the acquisition, processing and interpretation methods were tested on calibration spots to check for trypsin and calibration mixture peaks. Subsequently, the MALDI plate was calibrated. All spectra were collected in positive ion mode. The plate was set with continuous stage motion. 
The details of the acquisition methods used for MS and MS/MS collection are as follows. For MS data collection, the selected mass range was 800-4,000 Da with a focus mass of 1,800 Da. Two hundred laser shots were fired per sub-spectrum. Five sequential pass rounds of sub-spectra collection were required for acceptance. Subspectra were accepted when peaks had a signal to noise ratio $(s / n) \geq 4$. The collective 1000 shots were merged to create one spectrum. For MS/MS data collection, collision induced dissociation (CID) was turned on, and air molecules filled the collision chamber. Acquiring spectra required 250 shots per sub-spectrum. Two rounds of sub-spectra accumulation were required to merge 500 shots per spectrum. All sub-spectra were accepted. The metastable suppressor was turned on.

The processing method used required a minimum of three calibration peaks matched in each spectrum, and a mass tolerance of $+/-0.5 \mathrm{~m} / \mathrm{z}$. The interpretation method was used to link the MS data for MS/MS spectra collection. From the MS data, the strongest peaks were examined first. Ten precursor ions per spot were selected for further processing.

There are three ways the plate can be calibrated; internal, external and default. The selected method of calibration was internal by adding calibrant to the matrix solution before mixing with samples. However, if calibration failed a default calibration method was used. In some cases, external calibration was used.

\subsection{Protein identification}

Peptide masses were searched using MASCOT (Version 2.4.01, Boston, MA) against the S. cerevisiae UniProtKB/Swiss-Prot database (Version 20081216, and 405,506 sequences; $6,743 \mathrm{~S}$. cerevisiae sequences) with the peptide mass tolerance set at $40 \mathrm{ppm}$. The search criteria included allowance for one missed trypsin cleavage, complete modification of cysteine by carbamidomethyl, and variable methionine oxidation. The criteria for a match included the number of peptides matched, sequence coverage and significance scores. For proteins that were poorly annotated sequences were additionally searched using BLAST. 


\subsection{Gene Ontology}

The gene ontology (GO) website Kyoto Encyclopedia of Genes and Genomes (KEGG) was used for GO annotations of proteins using www.genome.jp/kegg/tool/map_pathway2.html.

\subsection{Spectrophotometric assays}

Glucose and ethanol in cell culture supernatants were measured using spectrophotometric assays. A Cary spectrophotometer was used for all experiments.

\subsubsection{Glucose assay}

Glucose was measured using a glucose oxidase-peroxidase kit (Sigma-Aldrich) that coupled oxidation of glucose to $\mathrm{H} 2 \mathrm{O} 2$ mediated oxidation of o-dianisidine. The volume of sample tested varied between conditions due to the glucose concentration. The supernatants of $0.2 \%$ and $0.5 \%$ glucose grown cells were diluted 100X, whilst the supernatants of the $2 \%$ glucose grown cells were diluted 1000X. Each set of assays included a media only blank and a glucose standard curve with 5-25 $\mu$ g glucose. Reactions were started by addition of $660 \mu \mathrm{L}$ of Assay Reagent then mixed by inversion and incubated at $37^{\circ} \mathrm{C}$ for $30 \mathrm{~min}$. Reactions were stopped by adding $590 \mu \mathrm{L}$ of $6 \mathrm{M} \mathrm{H} 2 \mathrm{SO} 4$ followed by measuring the absorbances at $540 \mathrm{~nm}$.

\subsubsection{Ethanol assay}

To measure the amount of ethanol produced by yeast cells an alcohol dehydrogenase $\mathrm{ADH}_{-N A D}{ }^{+}$assay was used. Oxidation of ethanol by alcohol dehydrogenase was

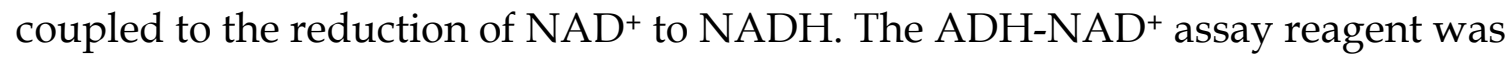
prepared by reconstituting ADH-NAD+ in pH 9.0 0.5 M glycine buffer. An ethanol standard was made by diluting absolute ethanol to give a $20 \mu \mathrm{mol} / \mu \mathrm{L}$ stock and creating a 0.05-0.2 $\mu \mathrm{mol}$ standard curve. Proteins were precipitated from yeast supernatants by adding equal volumes of $10 \%$ TCA and sample supernatants, $10 \mu \mathrm{L}$ of this was used for analysis. The reaction was started by the addition of $1 \mathrm{~mL}$ of NAD-ADH reagent, inverting the samples followed by an incubation period of $60 \mathrm{~min}$ at $37^{\circ} \mathrm{C}$. Absorbances were measured at $340 \mathrm{~nm}$.

\subsection{Differential in Gel Electrophoresis (DIGE)}

DIGE was used to compare the protein profiles of respiring and fermenting BY4741 cells. Cyanine (Cy) dye reagents were used for fluorescent labelling of samples for 
comparative analysis. A protein concentration between 4-10 $\mu \mathrm{g}$ protein/ $\mu \mathrm{L}$ was required for optimal Cy dye binding. For dilute protein samples, precipitation of protein was carried out to concentrate the sample (see section 2.10). However, instead of resuspending the protein pellet in rehydration buffer, a smaller volume of lysis buffer was added and protein concentrations were re-quantified (see section 2.9).

For labelling, the $\mathrm{pH}$ of protein $(10 \mu \mathrm{g})$ samples was adjusted by the addition of 1.5 M Tris to $\mathrm{pH} \geq 8.5$. A $1 \mathrm{mM}$ working stock solution was made for each $\mathrm{Cy}$ dye in N, N-dimethylformamide (Sigma-Aldrich), and each solution was vortexed and briefly centrifuged $(10 \mathrm{sec})$. The labelling scheme for randomisation of dye labelling is shown in Table 3. For consistency between gels, a control was made using all eight samples $(5 \mu \mathrm{g} \mathrm{3 \%} \mathrm{G2a}+5 \mu \mathrm{g} 3 \% \mathrm{G} 2 \mathrm{~b}+5 \mu \mathrm{g} 3 \% \mathrm{G} 2 \mathrm{c}+5 \mu \mathrm{g} 3 \% \mathrm{G} 2 \mathrm{~d}+5 \mu \mathrm{g} 2 \%$ Da + $5 \mu \mathrm{g} 2 \% \mathrm{Db}+5 \mu \mathrm{g} 2 \% \mathrm{Dc}+5 \mu \mathrm{g} 3 \% \mathrm{Dd})$ and divided evenly between each replicate (10 $\mu \mathrm{g}$ used).

Samples were vortexed and centrifuged briefly (10 sec), before being left on ice in the dark for $30 \mathrm{~min}$. The reaction was stopped by a $1 \mu \mathrm{L}$ addition of $10 \mathrm{mM}$ lysine, vortexed and centrifuged, and left for $15 \mathrm{~min}$ in the dark. Each sample set was then mixed together i.e. Cy2, Cy3 and Cy 5 labelled samples. This was then ready for protein precipitation as a clean-up step for preparation for the rehydration of samples for IEF (see section 2.10).

Table 3 - The DIGE labeling design for the comparison of glucose (D) and glycerol $(\mathrm{G})$ grown cells. The second letter $(\mathrm{a}-\mathrm{d})$ shows the replicate used.

\begin{tabular}{|l|l|l|l|}
\hline Gel number & Cy 3 labelled & Cy 5 labelled & Cy 2 standard \\
\hline 1 & $10 \mu \mathrm{g} 3 \% \mathrm{G} \mathrm{a}$ & $10 \mu \mathrm{g} \% \mathrm{D} \mathrm{c}$ & $10 \mu \mathrm{g}$ pool of all 4 samples \\
\hline 2 & $10 \mu \mathrm{g} 3 \% \mathrm{G} \mathrm{b}$ & $10 \mu \mathrm{g} \% \mathrm{D} \mathrm{d}$ & $10 \mu \mathrm{g}$ pool of all 4 samples \\
\hline 3 & $10 \mu \mathrm{g} \% \mathrm{G} \mathrm{c}$ & $10 \mu \mathrm{g} \% \mathrm{D} \mathrm{a}$ & $10 \mu \mathrm{g}$ pool of all 4 samples \\
\hline 4 & $10 \mu \mathrm{g} 3 \% \mathrm{G} \mathrm{d}$ & $10 \mu \mathrm{g} \% \mathrm{D} \mathrm{b}$ & $10 \mu \mathrm{g}$ pool of all 4 samples \\
\hline
\end{tabular}

\subsection{Fluorescent scanning}

Gels containing Cy dye labelled samples were scanned immediately after SDS PAGE. Gel images were digitized using a Fujifilm Fluorescent Image Analyser FLA-5100 
scanner (Fuji Photo Film Co., Ltd, Tokyo, Japan) at 16 bits per pixel with a $50 \mu \mathrm{m}$ pixel size at each Cy dye excitation wavelength (Table 4), at $600 \mathrm{~V}$. Post-fluorescent scanning, the gels were stained with CBB G-250(see section 2.8). Acquired images were saved as .tiff files.

Table 4 - Excitation wavelengths for each Cy dye and the type of emission filter used for each wavelength.

\begin{tabular}{|c|c|c|}
\hline Cyanine dye & Wavelength $(\mathrm{nm})$ & Emission filter \\
\hline 2 & 473 & BPB1/ 530DF20 \\
\hline 3 & 532 & BPG1/ 570DF20 \\
\hline 5 & 635 & DBR1/ R665 \\
\hline
\end{tabular}

\subsection{Preparation of gel images for DeCyder ${ }^{\mathrm{TM}}$ analysis}

Before the images were analyzed they were converted from tiff files to .gel files using ImageQuant Tools ${ }^{\mathrm{TM}}$ software (Version 2.2, Molecular Dynamics). The .gel files were used to create a dataset file using Fluorochrome separation ${ }^{\mathrm{TM}}$ software (Multicolour version 2.2, Molecular Dynamics). This overlayed the Cy 2, 3 and 5 images for each gel set, i.e. one data set per replicate was created. The dataset images were cropped using ImageQuant Tools ${ }^{\mathrm{TM}}$, for exclusion of excess Cy dye that accumulated at the bottom and sides of the gel.

\subsection{Data analysis using Decyder ${ }^{\mathrm{TM}}$ software}

The scanned images of the Cy dye labelled gels were analyzed using the DeCyderTM software (Version 6.5, GE Healthcare). Protein spots were matched to a master gel, the one with the most spots. Gels were set to identify 2,500 protein spots although some detected 'spots' were due to noise generated from streaking or excess dye providing false spots. Detected spots were assessed to differentiate between protein spots (curved peaks) from noise (sharp peaks). The determination of proteins that varied between substrate conditions was done using a Student's $t$-test $(\mathrm{p} \leq 0.01)$ and selecting $\mathrm{a} \geq 2$-fold change in protein abundance between samples. Protein abundances are log standardized by DeCyder ${ }^{\mathrm{TM}}$ software for comparative analysis. The degree of change of the standardized protein abundances between the conditions is represented by an average ratio. An average ratio greater or equal to a 
2-fold change, positive or negative, is considered significant when using replicates of four (Karp \& Lilley, 2005). The average ratio represents a change in protein abundance of one condition in relation to the other. To interpret changes in protein abundance for the glucose/glycerol experiment the degree of change was analyzed in relation to the glucose set. Therefore a positive average ratio indicates an increase in abundance in glucose and a negative ratio indicates an increase in protein abundance in the glycerol set. 


\section{Results}

\subsection{Growth analysis}

S. cerevisiae divides by budding. The time it takes to create the daughter cell (budding/division time) is dependent on a number of factors such as the strain and growth conditions. S. cerevisiae naturally ferments when glucose is abundant. However, this yeast respires when grown on a non-fermentable carbon source such as glycerol. The aim of this set of experiments was to examine the growth of BY4741 in glucose and glycerol for proteomic analysis.

The growth of BY4741 in synthetic complete (SC) medium supplemented with glucose or glycerol as a carbon source is shown in Figure 8. The time taken for cell collection $\mathrm{OD}_{600}=0.5$ was approximately $14 \mathrm{~h}$, the doubling time was $2 \mathrm{~h} 5 \mathrm{~min}$. The second experiment was designed to examine growth of BY4741 in the nonfermentative carbon source glycerol (Figure 8 bottom). The time taken to reach an $\mathrm{OD}_{600}$ of 0.5 was approximately $45 \mathrm{~h}$. The doubling time of BY4741 in 3\% glycerol supplemented SC media was calculated as $9 \mathrm{~h} 41 \mathrm{~min}$, approximately 5X slower than when cells were grown in glucose. Figure 9 shows the $\log _{10}$ growth of S. cerevisiae in $2 \%$ glucose (top) or $3 \%$ glycerol (bottom). 

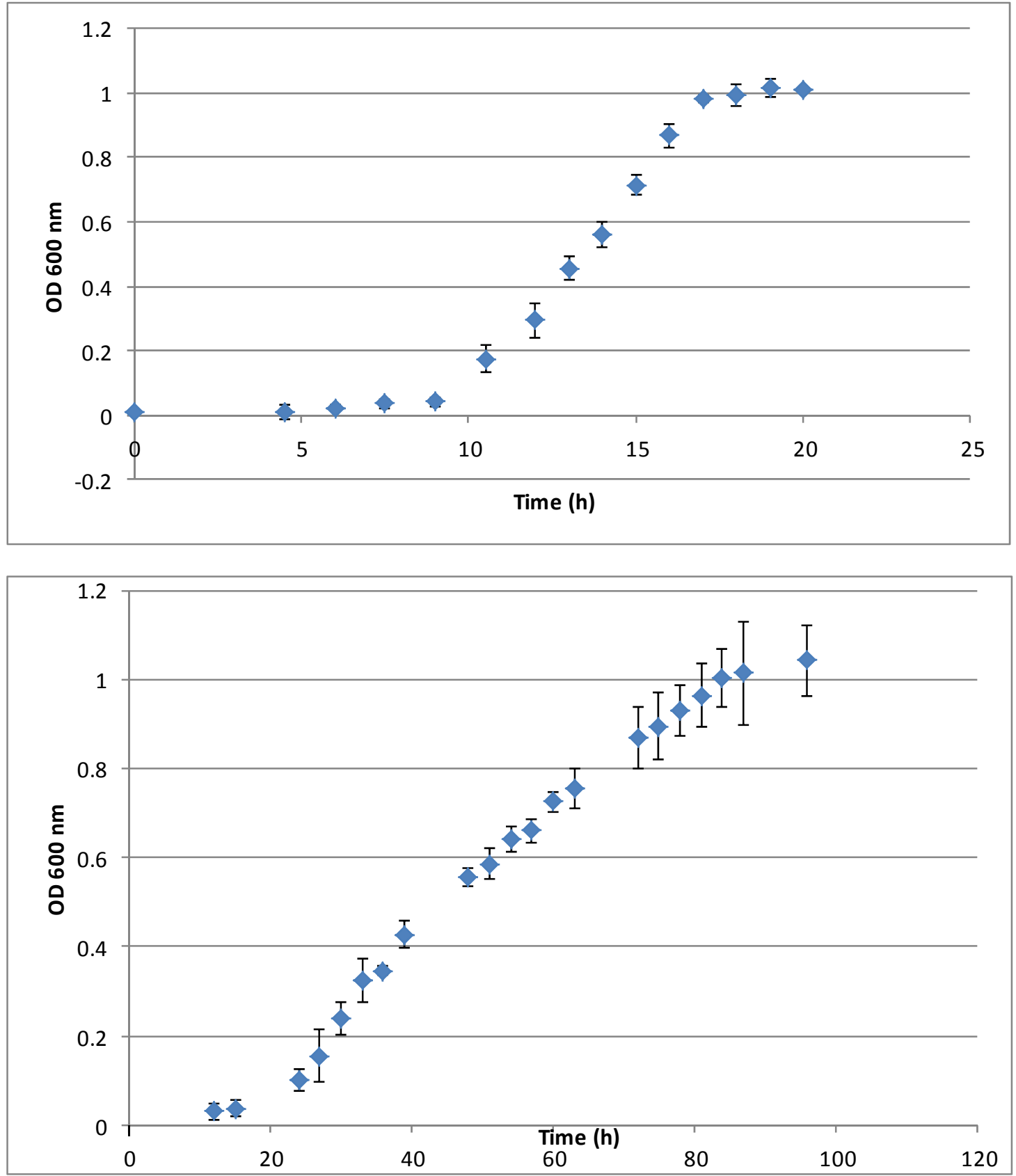

Figure 8 - Growth of BY4741 in 2\% glucose (top) or 3\% glycerol (bottom) and SC media. Aliquots of cultures were diluted (10X) and the absorbance was measured at $600 \mathrm{~nm}$ for glucose or glycerol grown cells. Cultures of BY4741 were grown in triplicate, error bars are standard deviations. 

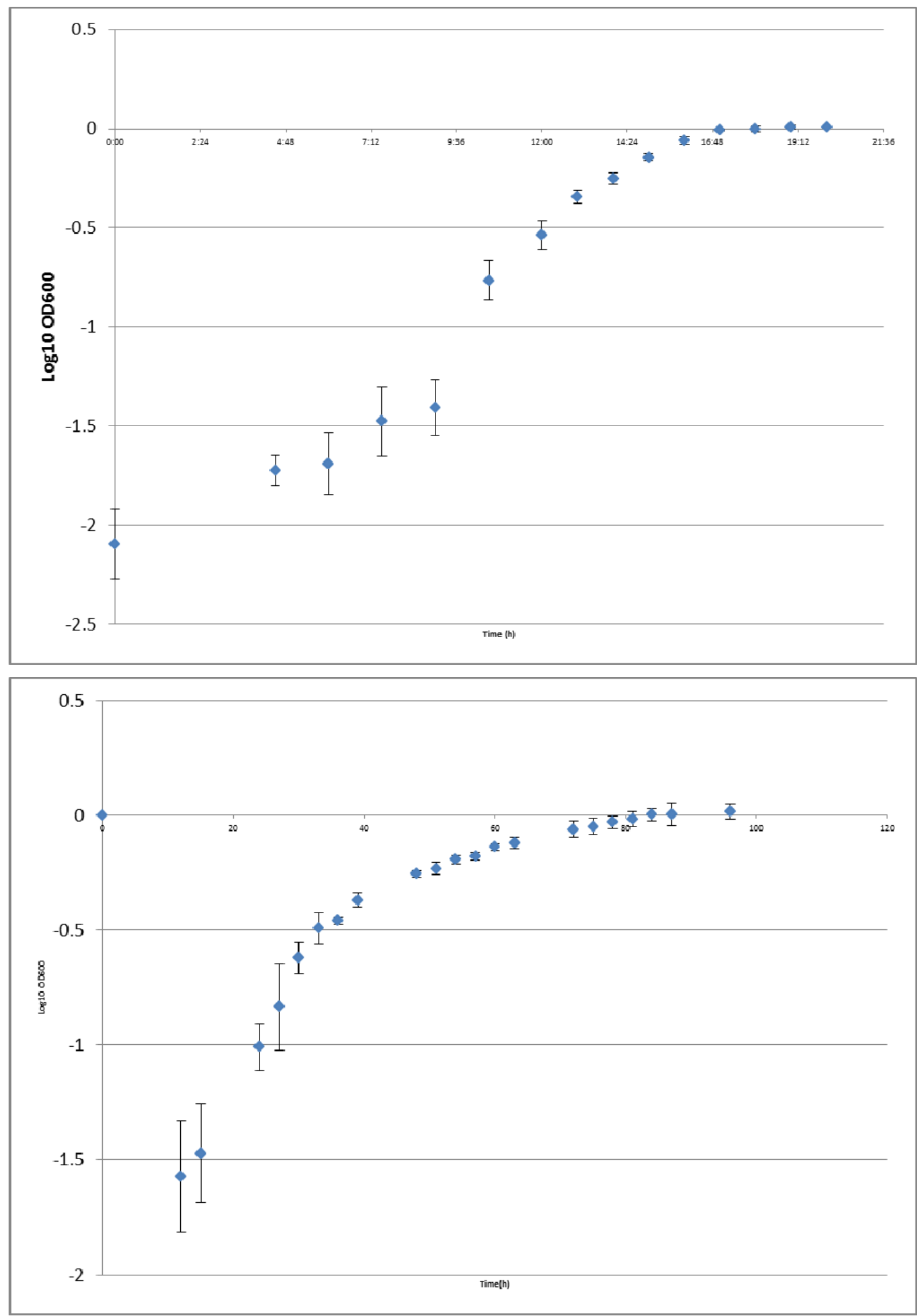

Figure 9 - Log $_{10}$ growth curves of BY4747 in 2\% glucose (top) or 3\% glycerol (bottom) and SC media. Aliquots of cultures were diluted (10X) and the absorbance was measured at $600 \mathrm{~nm}$ for glucose or glycerol grown cells. Cultures of BY4741 were grown in triplicate, error bars are standard deviations. 


\subsection{Extraction protocols and optimization of separation techniques for $2 \mathrm{D}$ analysis of a proteome}

Three sets of experiments were designed to develop protocols for proteome analysis of BY4741. The parameters that were examined include methods for protein extraction, $\mathrm{pH}$ ranges for IEF, and optimization of protein separation by the method of application of sample to IPG strips.

\subsubsection{Protein extraction}

The first experiment compared two extraction methods; disruption of cells by homogenization in lysis buffer (4\% w/v CHAPS, $2 \mathrm{M}$ thiourea, $7 \mathrm{M}$ urea, $30 \mathrm{mM}$ Tris $\mathrm{pH} 8.8$ ) with quartz sand, and use of a protein extraction kit (GE Healthcare). The resulting protein profiles were analyzed by 1D SDS PAGE (Figure 10). The yeast cells were grown to stationary phase $(\mathrm{OD} \geq 1)$ in $2 \%$ glucose in YP or SC media. The protein lysates produced using the kit protocol gave relatively few proteins $>55 \mathrm{kDa}$ from BY4741 grown cultures in YP or SC media (Figure 10, lanes 2 and 3 respectively). The lysis buffer protocol gave better 1D SDS PAGE extraction profiles with proteins ranging from 6-200 kDa in both the YP or SC grown cells (Figure 10, lanes 4 and 5 respectively).

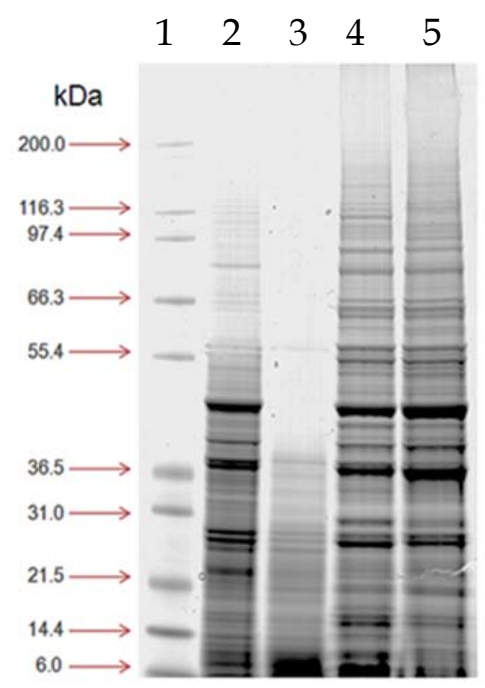

Figure 10 - Comparison of protein extraction methods analyzed by 1D SDS PAGE. The two methods used were lysis buffer (4\% w/v CHAPS, $2 \mathrm{M}$ thiourea, $7 \mathrm{M}$ urea, 30 $\mathrm{mM}$ Tris $\mathrm{pH} 8.8$ ) with quartz sand (Lanes 4 \& 5), and a protein extraction kit (GE Healthcare) (Lanes $2 \& 3$ ); $10 \mu \mathrm{g}$ of protein of each sample was used. Cells were grown in SCD (Lanes $2 \& 4$ ) or YPD: media (Lanes 3 \& 5). Lane 1 contained Invitrogen Mark ${ }^{12}$ ladder. 


\subsubsection{Separation of yeast proteins by $2 \mathrm{DE}$ using different $\mathrm{pH}$ ranges on $7 \mathbf{c m}$ gels}

A broad $\mathrm{pH}$ range of 3-11 NL (Figure 11, top) and two overlapping linear ranges $\mathrm{pH}$ 4-7 and 6-11 (Figure 11, bottom left and right, respectively) were used. Although loaded with the same amount of protein 2DE using pH 3-11 NL IPG strips in the first dimension gave less protein spots than the overlapping $\mathrm{pH} 4-7$ and 6-11 ranges.

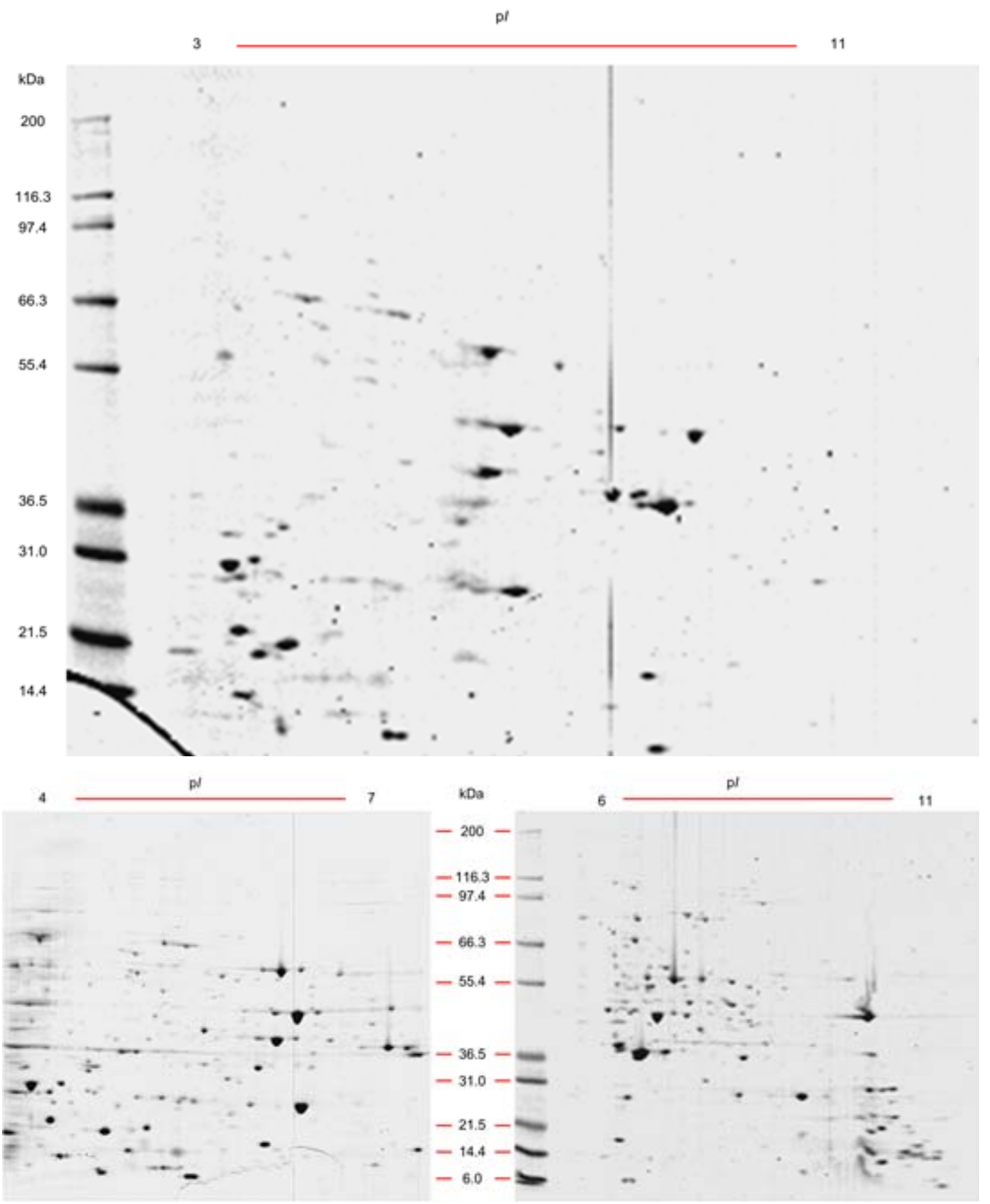

Figure 11 - Two-dimensional gel electrophoresis using three different $7 \mathrm{~cm}$ gradients for IEF. The gradients used were pH 3-11NL (top) and 4-7 and 6-11 (bottom; left and right). The Invitrogen Mark ${ }^{12}$ ladder was used as a molecular weight marker. Twenty micrograms of protein was loaded to each gel. 


\subsubsection{Optimization of $2 \mathrm{D}$ gels}

This experiment focused on improving the separation of proteins in the first dimension by comparing methods for sample application to IPG strips and the effect of protein precipitation.

Figure 12 shows 2DE on $7 \mathrm{~cm}$ SDS PAGE gels. Three sample application methods were examined using precipitated protein (left column) in comparison to nonprecipitated proteins (right column). Sample application by passive rehydration (top row) and cup loading at the cathode (middle row) on pH 4-7 IPG strips, and cup loading at the anode (bottom row) for pH 6-11 IPG strips were compared. During passive rehydration, samples are absorbed by the IPG strip overnight. In contrast, cup loading of protein at either the cathode or anode is a process where the sample is applied directly to the IPG strip during IEF. The method of cup loading of sample at the cathode was discarded due to loss of proteins in the mid $\mathrm{pH}$ range using either precipitated or non-precipitated protein samples (Figure 12, middle). Passive rehydration of sample for the separation of $\mathrm{pH}$ 4-7 proteins was therefore selected, and cup loading at the anode was used for focusing of basic proteins on $\mathrm{pH}$ 6-11 IPG strips. Protein precipitation was used for all subsequent sample preparations. 

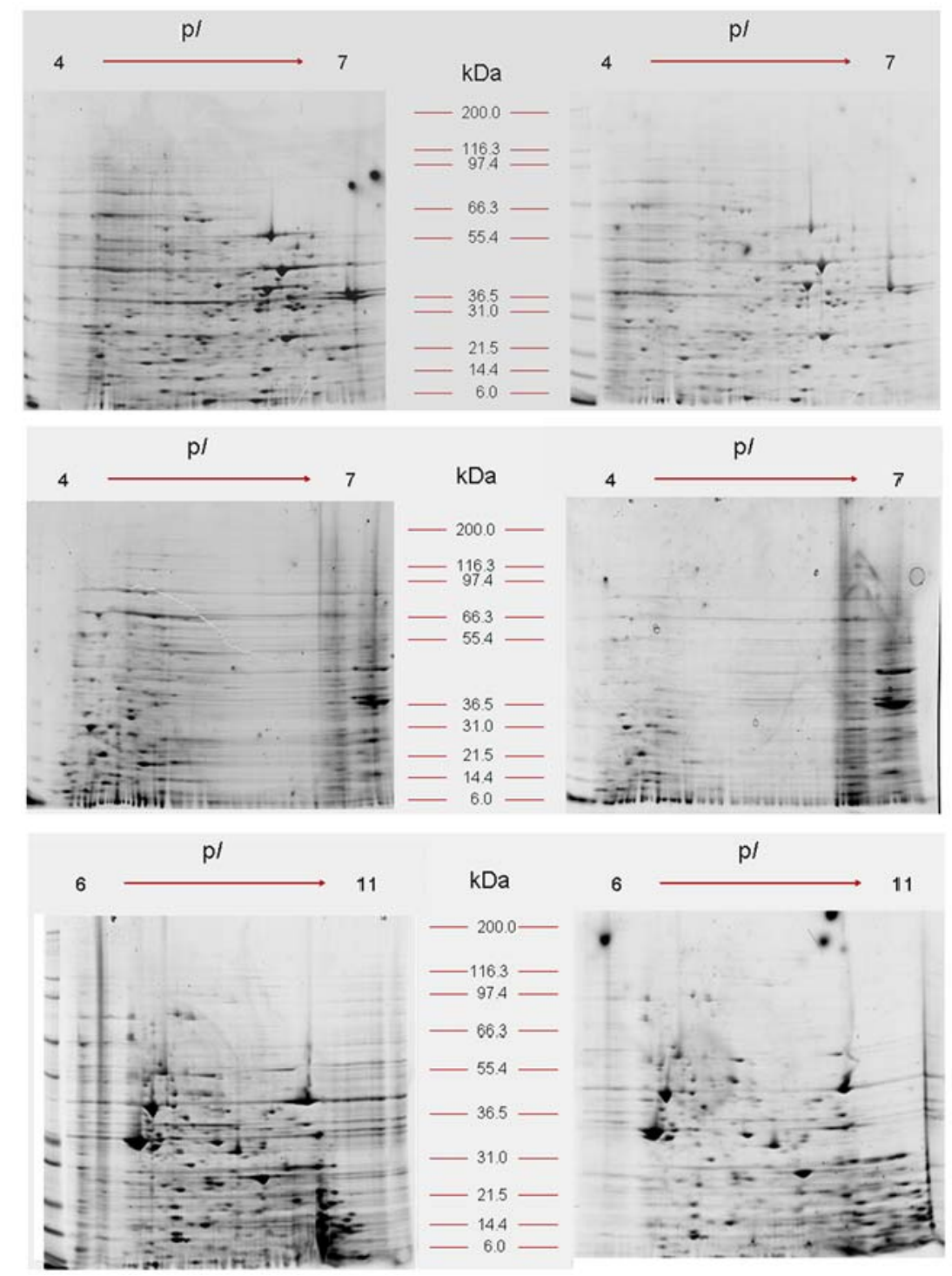

Figure 12 - Optimization of IEF. The experiment compared precipitated (left) against non-precipitated (right) protein samples. The first row are samples that were passively rehydrated, the middle row shows samples that were cup loaded at the cathode, and the bottom row shows samples which were cup loaded at the anode on a pH 6-11 gradient. The ladder used for molecular weight reference was Mark 12. Twenty micrograms of protein was used for each gel. 


\subsection{Protein identification}

Analysis by 2D-DIGE typically requires small amounts $(5 \mu \mathrm{g})$ of protein per sample for optimal binding of the Cy dye reagents. However, for the identification of proteins from gels, larger amounts of protein are often required. For the reference proteome experiment $100 \mu \mathrm{g}$ of protein from cells grown in $2 \%$ glucose in SC media was analyzed.

\subsubsection{D analysis of $\mathrm{pI}$ 4-7 proteins}

The protein profile of BY4741 separated on a pH 4-7 IPG strip is shown in Figure 13. The horizontal axis displays the isoelectric range of the $\mathrm{pH}$ gradient (first dimension) and the vertical axis, separation on the basis of size. The 2D gel image shows 232 proteins visible by Coomassie staining that were selected for MALDI mass fingerprinting. Significant identifications required a match with a MASCOT score greater than 56 at $p \leq 0.05$. A total of 109 proteins were identified at the $5 \%$ level of significance (Table 5). Of these, 70 unique protein identifications were found. Thirty-nine identifications accounted for proteins with multiple spots or protein isoforms. Proteins with multiple spots include Adh1, Eno1, Eno2, Gdh1, Hsp82, Hxk2, Pdc1, Pdi1, Psa1, Rps12, Ssa1, Ssa2, Ssb2 and Vma2. Isoforms of proteins included Ade13, Ade5,7, Bmh1, Bmh2, Eno1, Eno2, Hsp104, Hsp26, Hsp60, Hsp82, Rps0A, Rps12, Rps21A, Rps5, Ssa1, Ssa2, Ssb1, Ssb2, Tif2, Tif6, Tub1, Tub2,Vma2, Vma4, Vma6 and Vma7. Of particular interest were the six glycolytic enzymes (Eno1, Eno2, Gdh1, Hxk2, Pdc1 and Pdi1) and Adh1 (alcohol dehydrogenase) present in multiple spots and isoforms.

Table 5 summarizes each protein that was matched including protein name, mass, isoelectric point, sequence length and coverage, subcellular localization, information about function and identity, GI and accession numbers. The last column, second matched protein, represents the first non-homologous protein match. 


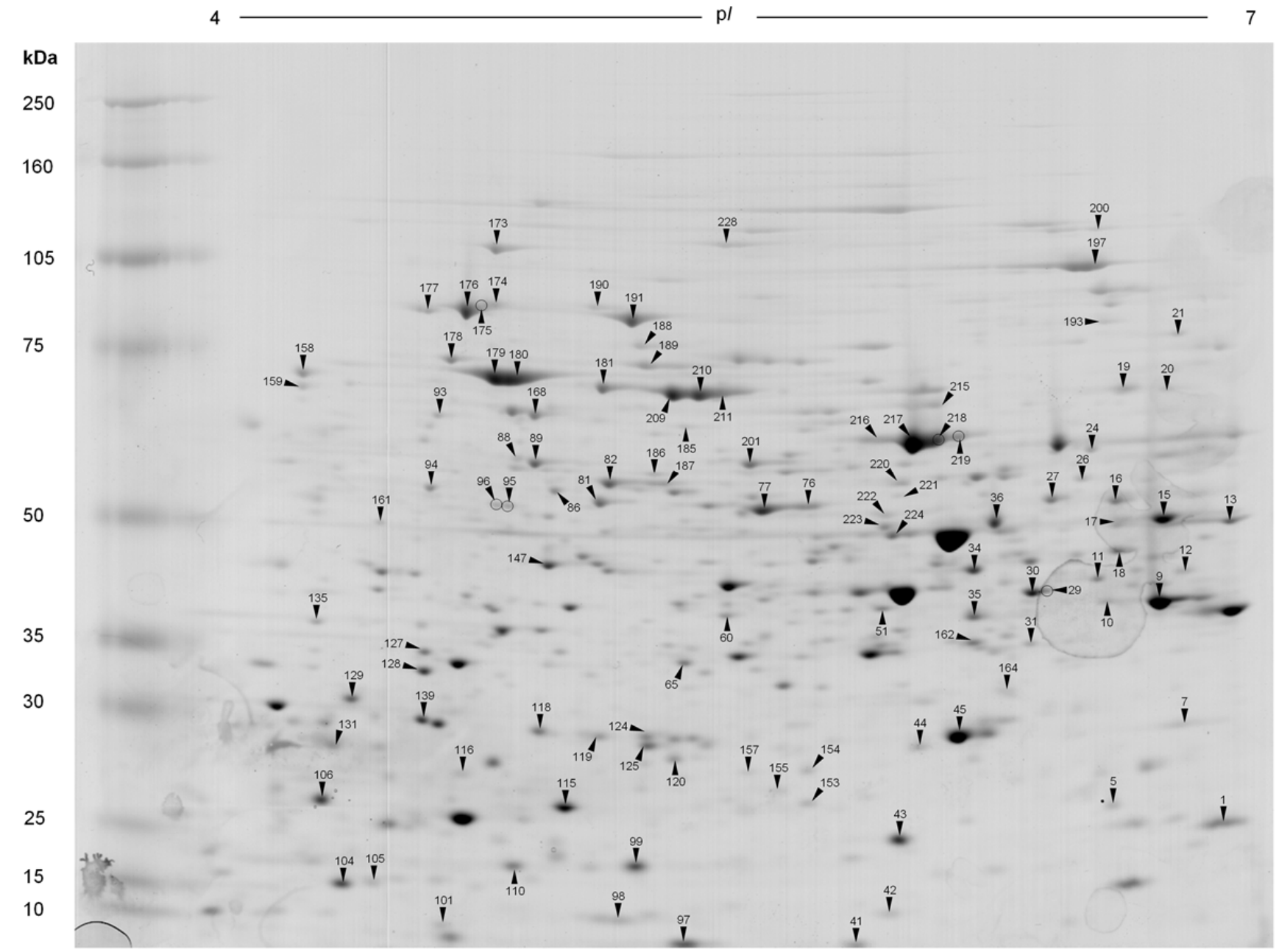

Figure 13 - The 2D gel image of the protein profile of S. cerevisiae BY4741 separated on a pH 4-7 linear gradient (horizontal axis). Separated proteins $(100 \mu \mathrm{g})$ were stained with Coomassie, and identified proteins are marked with an arrow. Numbers correspond to Table 5. The ladder used for molecular weight reference was Rainbow 851. 
Table 5 - Summary of identified BY4741 proteins by MALDI mass spectrometry and separated by 2DE using a pH 4-7 gradient. Proteins (score $\geq 56, p \leq 0.05)$ are alphabetized by gene name. The score and sequence coverage $(\%)$ values are representative of the significance of the match generated by the MASCOT search. The calculated mass, pI, GI, accession number and description of the protein were gathered from the NCBI protein website. The subcellular localization of the protein was found using Uniprot. The next matched protein was the next non-homologous protein matched. The spot position was cross checked with the calculated $\mathrm{pI}$ and Mr values. Differences between observed and predicted mass and / or $\mathrm{pI}$ are labeled A: acidic shift or B: basic shift in $\mathrm{pI}$ and/or I: increase or D: decrease in Mr.

\begin{tabular}{|c|c|c|c|c|c|c|c|c|c|c|c|}
\hline $\begin{array}{l}\text { Spot } \\
\text { No }\end{array}$ & $\begin{array}{l}\text { Gene } \\
\text { name }\end{array}$ & $\begin{array}{l}\text { Mass } \\
{[\mathrm{kDa}]}\end{array}$ & $\begin{array}{c}\mathrm{p} / \\
{[\mathrm{pH}]}\end{array}$ & $\begin{array}{c}\text { Sequence } \\
\text { length } \\
{[A A]}\end{array}$ & Score & $\begin{array}{c}\text { Sequence } \\
\text { Coverage } \\
{[\%]}\end{array}$ & GI No. & $\begin{array}{c}\text { Accession No } \\
\text { [SwissProtKB/ } \\
\text { Swiss-Prot/ } \\
\text { S.cerevisiae] } \\
\text { (BLAST } \\
\text { Accession No) }\end{array}$ & $\begin{array}{l}\text { Subcellular } \\
\text { localization }\end{array}$ & Description & $\begin{array}{l}\text { Next match, } \\
\text { GI No. } \\
\text { (score) }\end{array}$ \\
\hline $177^{\mathrm{IA}}$ & $A B P 1$ & 65.59 & 4.59 & 592 & 178 & 21 & gi|6319931 & NP_010012 & $\begin{array}{l}\text { Cytoplasm > } \\
\text { cytoskeleton > } \\
\text { actin patch }\end{array}$ & $\begin{array}{l}\text { Actin-binding protein of } \\
\text { the cortical actin } \\
\text { cytoskeleton, important } \\
\text { for activation of the Arp2/3 } \\
\text { complex that plays a key } \\
\text { role actin in cytoskeleton } \\
\text { organization. }\end{array}$ & $\begin{array}{l}\text { AWRI1631_- } \\
\text { 160620, } \\
\text { gi|20734070 } \\
7(33)\end{array}$ \\
\hline $60^{\mathrm{D}}$ & ACT1 & 41.89 & 5.44 & 375 & 246 & 19 & gi|14318479 & NP_116614 & $\begin{array}{l}\text { Cytoplasm > } \\
\text { cytoskeleton }\end{array}$ & $\begin{array}{l}\text { Actin, structural protein } \\
\text { involved in cell } \\
\text { polarization, endocytosis, } \\
\text { and other cytoskeletal } \\
\text { functions. }\end{array}$ & $(-)$ \\
\hline
\end{tabular}




\begin{tabular}{|c|c|c|c|c|c|c|c|c|c|c|c|}
\hline $\begin{array}{l}\text { Spot } \\
\text { No }\end{array}$ & $\begin{array}{l}\text { Gene } \\
\text { name }\end{array}$ & $\begin{array}{l}\text { Mass } \\
{[\mathrm{kDa}]}\end{array}$ & $\begin{array}{c}\mathrm{p} / \\
{[\mathrm{pH}]}\end{array}$ & $\begin{array}{l}\text { Sequence } \\
\text { length } \\
{[A A]}\end{array}$ & Score & $\begin{array}{c}\text { Sequence } \\
\text { Coverage } \\
{[\%]}\end{array}$ & GI No. & $\begin{array}{c}\text { Accession No } \\
\text { [SwissProtKB/ } \\
\text { Swiss-Prot/ } \\
\text { S.cerevisiae] } \\
\text { (BLAST } \\
\text { Accession No) }\end{array}$ & $\begin{array}{l}\text { Subcellular } \\
\text { localization }\end{array}$ & Description & $\begin{array}{l}\text { Next match, } \\
\text { GI No. } \\
\text { (score) }\end{array}$ \\
\hline $26^{\mathrm{B}}$ & $A D E 13$ & 54.7 & 6.01 & 482 & 139 & 24 & gi|6323391 & NP_013463 & Unknown & $\begin{array}{l}\text { Adenylosuccinate lyase } \\
\text { catalyzes two steps in the } \\
\text { 'de novo' purine } \\
\text { nucleotide biosynthetic } \\
\text { pathway; expression is } \\
\text { repressed by adenine and } \\
\text { activated by Bas1p and } \\
\text { Pho2p. }\end{array}$ & $\begin{array}{c}\text { Erp6p, } \\
\text { gi|6321436 } \\
(25)\end{array}$ \\
\hline 190 & ADE5,7 & 86.35 & 5.08 & 802 & 174 & 15 & gi|6321203 & NP_011280 & Cytoplasm & $\begin{array}{l}\text { Bifunctional enzyme of } \\
\text { the 'de novo' purine } \\
\text { nucleotide biosynthetic } \\
\text { pathway contains } \\
\text { aminoimidazoleribotide } \\
\text { synthetase and } \\
\text { glycinamideribotide } \\
\text { synthetase activities. }\end{array}$ & $\begin{array}{c}\text { Pau9p, } \\
\text { gi|13129151 } \\
\text { (36) }\end{array}$ \\
\hline $9^{B}$ & $A D H 1$ & 37.15 & 6.21 & 347 & 295 & 26 & gi|112491285 & $\begin{array}{c}\text { 2HCY_A } \\
\left(\mathrm{NP} \_014555\right)\end{array}$ & Cytoplasm & $\begin{array}{c}\text { Chain A, Alcohol } \\
\text { dehydrogenase I, } \\
\text { fermentative enzyme. }\end{array}$ & $\begin{array}{l}\text { Cdc53p, } \\
\text { gi|6320070 } \\
(30)\end{array}$ \\
\hline $10^{B}$ & $A D H 1$ & 37.15 & 6.21 & 347 & 116 & 23 & gi|112491285 & $\begin{array}{c}\text { 2HCY_A } \\
\text { (NP_014555) }\end{array}$ & Cytoplasm & $\begin{array}{l}\text { Chain A, Alcohol } \\
\text { dehydrogenase I. }\end{array}$ & $(-)$ \\
\hline $31^{\mathrm{D}}$ & $A D H 1$ & 37.15 & 6.21 & 347 & 64 & 17 & gi|112491285 & $\begin{array}{c}\text { 2HCY_A } \\
\text { (NP_014555) }\end{array}$ & Cytoplasm & $\begin{array}{l}\text { Chain A, Alcohol } \\
\text { dehydrogenase I. }\end{array}$ & $(-)$ \\
\hline
\end{tabular}




\begin{tabular}{|c|c|c|c|c|c|c|c|c|c|c|c|}
\hline $\begin{array}{l}\text { Spot } \\
\text { No }\end{array}$ & $\begin{array}{l}\text { Gene } \\
\text { name }\end{array}$ & $\begin{array}{l}\text { Mass } \\
{[\mathrm{kDa}]}\end{array}$ & $\begin{array}{c}\mathrm{p} / \\
{[\mathrm{pH}]}\end{array}$ & $\begin{array}{l}\text { Sequence } \\
\text { length } \\
{[\mathrm{AA}]}\end{array}$ & Score & $\begin{array}{c}\text { Sequence } \\
\text { Coverage } \\
{[\%]}\end{array}$ & GI No. & $\begin{array}{c}\text { Accession No } \\
\text { [SwissProtKB/ } \\
\text { Swiss-Prot/ } \\
\text { S.cerevisiae] } \\
\text { (BLAST } \\
\text { Accession No) }\end{array}$ & $\begin{array}{l}\text { Subcellular } \\
\text { localization }\end{array}$ & Description & $\begin{array}{l}\text { Next match, } \\
\text { GI No. } \\
\text { (score) }\end{array}$ \\
\hline $44^{\prime}$ & $A D K 1$ & 24.29 & 5.98 & 222 & 101 & 18 & gi|6320432 & NP_010512 & $\begin{array}{c}\text { Cytoplasm } \\
\text { Mitochondrion } \\
\text { intermembrane } \\
\text { space }\end{array}$ & $\begin{array}{c}\text { Adenylate kinase, } \\
\text { required for purine } \\
\text { metabolism; lacks } \\
\text { cleavable signal } \\
\text { sequence. }\end{array}$ & $(-)$ \\
\hline $201^{\mathrm{B}}$ & $A L D 6$ & 54.77 & 5.31 & 500 & 199 & 30 & gi|6325196 & NP_015264 & Cytoplasm & $\begin{array}{l}\text { Aldehyde dehydrogenase, } \\
\text { activated by Mg2+ and } \\
\text { utilizes NADP+ as the } \\
\text { preferred coenzyme; } \\
\text { required for conversion of } \\
\text { acetaldehyde to acetate; } \\
\text { constitutively expressed; } \\
\text { locates to the } \\
\text { mitochondrial outer } \\
\text { surface upon oxidative } \\
\text { stress }\end{array}$ & $\begin{array}{c}\text { BSC4, } \\
\text { gi|17096302 } \\
3(27)\end{array}$ \\
\hline$\underset{B}{220^{D}}$ & ARO8 & 56.37 & 5.68 & 500 & 149 & 9 & gi|6321236 & NP_011313 & Cytoplasm & $\begin{array}{c}\text { Aromatic } \\
\text { aminotransferase I, } \\
\text { expression is regulated by } \\
\text { general control of amino } \\
\text { acid biosynthesis. }\end{array}$ & $\begin{array}{c}\text { Pau9p, } \\
\text { gi|13129151 } \\
\text { (36) }\end{array}$ \\
\hline 81 & ATP2 & 51.09 & 5.11 & 478 & 85 & 24 & gi|119389907 & $\begin{array}{c}\text { 2HLD_D } \\
\left(\mathrm{NP} \_012655\right)\end{array}$ & Mitochondrion & $\begin{array}{c}\text { Chain D, Mitochondrial } \\
\text { F1-Atpase }\end{array}$ & $\begin{array}{c}\operatorname{lgo} 1 \mathrm{p} \\
\text { gi|6324172 } \\
(29)\end{array}$ \\
\hline
\end{tabular}




\begin{tabular}{|c|c|c|c|c|c|c|c|c|c|c|c|}
\hline $\begin{array}{l}\text { Spot } \\
\text { No }\end{array}$ & $\begin{array}{l}\text { Gene } \\
\text { name }\end{array}$ & $\begin{array}{l}\text { Mass } \\
{[\mathrm{kDa}]}\end{array}$ & $\begin{array}{c}\mathrm{pl} \\
{[\mathrm{pH}]}\end{array}$ & $\begin{array}{c}\text { Sequence } \\
\text { length } \\
{[\mathrm{AA}]}\end{array}$ & Score & $\begin{array}{c}\text { Sequence } \\
\text { Coverage } \\
{[\%]}\end{array}$ & GI No. & $\begin{array}{c}\text { Accession No } \\
\text { [SwissProtKB/ } \\
\text { Swiss-Prot/ } \\
\text { S.cerevisiae] } \\
\text { (BLAST } \\
\text { Accession No) }\end{array}$ & $\begin{array}{l}\text { Subcellular } \\
\text { localization }\end{array}$ & Description & $\begin{array}{l}\text { Next match, } \\
\text { GI No. } \\
\text { (score) }\end{array}$ \\
\hline $128^{\prime}$ & $B M H 1$ & 30.18 & 4.82 & 267 & 92 & 12 & gi|6321025 & NP_011104 & $\begin{array}{l}\text { Nucleus } \\
\text { Plasma } \\
\text { membrane }\end{array}$ & $\begin{array}{l}\text { 14-3-3 protein, major } \\
\text { isoform; controls } \\
\text { proteome at post- } \\
\text { transcriptional level, binds } \\
\text { proteins and DNA, } \\
\text { involved in regulation of } \\
\text { many processes including } \\
\text { exocytosis, vesicle } \\
\text { transport, Ras/MAPK } \\
\text { signaling, and rapamycin- } \\
\text { sensitive signaling. }\end{array}$ & $\begin{array}{c}\text { AWRI1631_ } \\
\text { 141000, } \\
\text { gi|20734187 } \\
8(28)\end{array}$ \\
\hline $127^{1}$ & BMH2 & 30.97 & 4.82 & 273 & 328 & 35 & gi|151942087 & $\begin{array}{c}\text { EDN60443 } \\
\text { (NP_010384) }\end{array}$ & $\begin{array}{l}\text { Cytoplasm } \\
\text { Nucleus }\end{array}$ & $\begin{array}{l}\text { 14-3-3 protein, minor } \\
\text { isoform; controls } \\
\text { proteome at post- } \\
\text { transcriptional level, binds } \\
\text { proteins and DNA, } \\
\text { involved in regulation of } \\
\text { many processes including } \\
\text { exocytosis, vesicle } \\
\text { transport, Ras/MAPK } \\
\text { signaling, and rapamycin- } \\
\text { sensitive signaling. }\end{array}$ & $\begin{array}{c}\text { Pau9p, } \\
\text { gi|13129151 } \\
\text { (23) }\end{array}$ \\
\hline $185^{\mathrm{B}}$ & ССT5 & 61.17 & 5.31 & 551 & 59 & 9 & gi|567930 & $\begin{array}{c}\text { AAA53132 } \\
\text { (NP_012598) }\end{array}$ & Cytoplasm & TCP1 & $\begin{array}{c}\text { SCY_2605, } \\
\text { gi| } 15194323 \\
4(31)\end{array}$ \\
\hline
\end{tabular}




\begin{tabular}{|c|c|c|c|c|c|c|c|c|c|c|c|}
\hline $\begin{array}{l}\text { Spot } \\
\text { No }\end{array}$ & $\begin{array}{l}\text { Gene } \\
\text { name }\end{array}$ & $\begin{array}{l}\text { Mass } \\
{[\mathrm{kDa}]}\end{array}$ & $\begin{array}{c}\mathrm{p} / \\
{[\mathrm{pH}]}\end{array}$ & $\begin{array}{c}\text { Sequence } \\
\text { length } \\
{[A A]}\end{array}$ & Score & $\begin{array}{c}\text { Sequence } \\
\text { Coverage } \\
{[\%]}\end{array}$ & GI No. & $\begin{array}{c}\text { Accession No } \\
\text { [SwissProtKB/ } \\
\text { Swiss-Prot/ } \\
\text { S.cerevisiae] } \\
\text { (BLAST } \\
\text { Accession No) }\end{array}$ & $\begin{array}{l}\text { Subcellular } \\
\text { localization }\end{array}$ & Description & $\begin{array}{l}\text { Next match, } \\
\text { GI No. } \\
\text { (score) }\end{array}$ \\
\hline $173^{\mathrm{IB}}$ & $C D C 48$ & 92.16 & 4.82 & 835 & 65 & 13 & gi|6320077 & NP_010157 & $\begin{array}{c}\text { ER } \\
\text { Microsome }\end{array}$ & $\begin{array}{l}\text { ATPase involved in } \\
\text { ubiquitin-mediated protein } \\
\text { degradation; Cdc48p- } \\
\text { Npl4p-Ufd1p complex } \\
\text { participates in ER- } \\
\text { associated degradation } \\
\text { (ERAD) while Cdc48p- } \\
\text { Npl4p-Vms1p complex } \\
\text { participates in } \\
\text { mitochondria-associated } \\
\text { degradation (MAD). }\end{array}$ & $\begin{array}{c}\text { YKR101Wp- } \\
\text { like protein, } \\
\text { gi|20734331 } \\
1 \text { (29) }\end{array}$ \\
\hline $110^{\mathrm{D}}$ & COF1 & 15.94 & 5.05 & 143 & 108 & 36 & gi|6322978 & NP_013050 & $\begin{array}{l}\text { Cytoplasm } \\
\text { >cytoskeleton } \\
\text { Nucleus }\end{array}$ & $\begin{array}{l}\text { Cofilin, promotes actin } \\
\text { filament depolarization in } \\
\text { a pH-dependent manner; } \\
\text { binds both actin } \\
\text { monomers and filaments } \\
\text { and severs filaments; } \\
\text { thought to be regulated by } \\
\text { phosphorylation at SER4; } \\
\text { ubiquitous and essential } \\
\text { in eukaryotes. }\end{array}$ & $\begin{array}{c}\text { Unnamed } \\
\text { protein } \\
\text { product, } \\
\text { gi|4772 (27) }\end{array}$ \\
\hline $1^{1}$ & CPR1 & 17.49 & 6.9 & 162 & 309 & 37 & gi|6320359 & NP_010439 & Cytoplasm & $\begin{array}{l}\text { Peptidyl-prolylcis-trans } \\
\text { isomerase (cyclophilin), } \\
\text { catalyzes the cis-trans } \\
\text { isomerization of peptide } \\
\text { bonds } \mathrm{N} \text {-terminal to } \\
\text { proline residues; binds the } \\
\text { drug cyclosporin A. }\end{array}$ & $\begin{array}{c}\text { Gas2p, } \\
\text { gi|6323375 } \\
(35)\end{array}$ \\
\hline
\end{tabular}




\begin{tabular}{|c|c|c|c|c|c|c|c|c|c|c|c|}
\hline $\begin{array}{l}\text { Spot } \\
\text { No }\end{array}$ & $\begin{array}{l}\text { Gene } \\
\text { name }\end{array}$ & $\begin{array}{l}\text { Mass } \\
{[\mathrm{kDa}]}\end{array}$ & $\begin{array}{c}\mathrm{pl} \\
{[\mathrm{pH}]}\end{array}$ & $\begin{array}{c}\text { Sequence } \\
\text { length } \\
{[A A]}\end{array}$ & Score & $\begin{array}{c}\text { Sequence } \\
\text { Coverage } \\
{[\%]}\end{array}$ & GI No. & $\begin{array}{c}\text { Accession No } \\
\text { [SwissProtKB/ } \\
\text { Swiss-Prot/ } \\
\text { S.cerevisiae] } \\
\text { (BLAST } \\
\text { Accession No) }\end{array}$ & $\begin{array}{l}\text { Subcellular } \\
\text { localization }\end{array}$ & Description & $\begin{array}{l}\text { Next match, } \\
\text { GI No. } \\
\text { (score) }\end{array}$ \\
\hline $11^{\mathrm{DB}}$ & CYS3 & 42.51 & 6.06 & 394 & 277 & 20 & gi|6319307 & NP_009390 & Cytoplasm & $\begin{array}{l}\text { Cystathionine gamma- } \\
\text { lyase catalyzes one of the } \\
\text { two reactions involved in } \\
\text { the transsulfuration } \\
\text { pathway that yields } \\
\text { cysteine from } \\
\text { homocysteine with the } \\
\text { intermediary formation of } \\
\text { cystathionine. }\end{array}$ & $\begin{array}{l}\text { Unnamed } \\
\text { protein } \\
\text { product, } \\
\text { gi|4025 (35) }\end{array}$ \\
\hline $19^{\mathrm{IB}}$ & DPS1 & 63.64 & 6.16 & 557 & 385 & 38 & gi|6323011 & NP_013083 & Cytoplasm & $\begin{array}{c}\text { Aspartyl-tRNA } \\
\text { synthetase, primarily } \\
\text { cytoplasmic; homodimeric } \\
\text { enzyme that catalyzes the } \\
\text { specific aspartylation of } \\
\text { tRNA (Asp); class II } \\
\text { aminoacyl tRNA } \\
\text { synthetase; binding to its } \\
\text { own mRNA may confer } \\
\text { autoregulation. }\end{array}$ & $\begin{array}{c}\text { Ade17p, } \\
\text { gi|6323768 } \\
\text { (51) }\end{array}$ \\
\hline $197^{1 \mathrm{~B}}$ & EFT2 & 93.68 & 5.92 & 842 & 234 & 20 & gi|6320593 & NP_010673 & Cytoplasm & $\begin{array}{l}\text { Elongation factor } 2 \text { (EF- } \\
\text { 2), also encoded by } \\
\text { EFT1; catalyzes } \\
\text { ribosomal translocation } \\
\text { during protein synthesis; } \\
\text { contains diphthamide, the } \\
\text { unique posttranslationally } \\
\text { modified histidine residue } \\
\text { specifically ADP- } \\
\text { ribosylated by diphtheria } \\
\text { toxin. }\end{array}$ & $\begin{array}{c}\text { Type } 2 \mathrm{C} \\
\text { protein } \\
\text { phosphatase } \\
\text { gi|11536165 } \\
1(31)\end{array}$ \\
\hline
\end{tabular}




\begin{tabular}{|c|c|c|c|c|c|c|c|c|c|c|c|}
\hline $\begin{array}{l}\text { Spot } \\
\text { No }\end{array}$ & $\begin{array}{l}\text { Gene } \\
\text { name }\end{array}$ & $\begin{array}{l}\text { Mass } \\
{[\mathrm{kDa}]}\end{array}$ & $\begin{array}{c}\mathrm{p} / \\
{[\mathrm{pH}]}\end{array}$ & $\begin{array}{c}\text { Sequence } \\
\text { length } \\
{[A A]}\end{array}$ & Score & $\begin{array}{c}\text { Sequence } \\
\text { Coverage } \\
{[\%]}\end{array}$ & GI No. & $\begin{array}{c}\text { Accession No } \\
\text { [SwissProtKB/ } \\
\text { Swiss-Prot/ } \\
\text { S.cerevisiae] } \\
\text { (BLAST } \\
\text { Accession No) }\end{array}$ & $\begin{array}{l}\text { Subcellular } \\
\text { localization }\end{array}$ & Description & $\begin{array}{l}\text { Next match, } \\
\text { GI No. } \\
\text { (score) }\end{array}$ \\
\hline $17^{\mathrm{IB}}$ & ENO1 & 46.84 & 6.16 & 437 & 131 & 7 & gi|6321693 & NP_011770 & Cytoplasm & $\begin{array}{l}\text { Enolase I, a } \\
\text { phosphopyruvate } \\
\text { hydratase that catalyzes } \\
\text { the conversion of 2- } \\
\text { phosphoglycerate to } \\
\text { phosphoenolpyruvate } \\
\text { during glycolysis and the } \\
\text { reverse reaction during } \\
\text { gluconeogenesis; } \\
\text { expression is repressed in } \\
\text { response to glucose. }\end{array}$ & $\begin{array}{c}\text { Cor1p, } \\
\text { gi|6319426 } \\
(52)\end{array}$ \\
\hline $15^{\mathrm{IB}}$ & ENO1 & 46.65 & 6.04 & 436 & 243 & 26 & gi|157830958 & $\begin{array}{c}\text { 1ELS_A } \\
(\mathrm{NP} \text {-011770) }\end{array}$ & Cytoplasm & $\begin{array}{c}\text { Chain A, Catalytic Metal } \\
\text { lon Binding In Enolase- } \\
\text { Mn2+- } \\
\text { Phosphonoacetohydroxa } \\
\text { mate Complex }\end{array}$ & $\begin{array}{c}\text { Chain A, 3- } \\
\text { Phosphoglyc } \\
\text { erate } \\
\text { Kinase, } \\
\text { Mutation } \\
\text { R65q. (69) }\end{array}$ \\
\hline $224^{\mathrm{IB}}$ & ENO2 & 46.94 & 5.67 & 437 & 371 & 37 & gi|6321968 & NP_012044 & Cytoplasm & $\begin{array}{l}\text { Phosphopyruvate } \\
\text { hydratase that catalyzes } \\
\text { the conversion of } 2- \\
\text { phosphoglycerate to } \\
\text { phosphoenolpyruvate } \\
\text { during glycolysis and the } \\
\text { reverse reaction during } \\
\text { gluconeogenesis; } \\
\text { expression is induced in } \\
\text { response to glucose. }\end{array}$ & $\begin{array}{c}\text { Pyruvate } \\
\text { kinase, } \\
\text { gi|4180 (76) }\end{array}$ \\
\hline
\end{tabular}




\begin{tabular}{|c|c|c|c|c|c|c|c|c|c|c|c|}
\hline $\begin{array}{c}\text { Spot } \\
\text { No }\end{array}$ & $\begin{array}{l}\text { Gene } \\
\text { name }\end{array}$ & $\begin{array}{l}\text { Mass } \\
{[\mathrm{kDa}]}\end{array}$ & $\begin{array}{c}\mathrm{p} / \\
{[\mathrm{pH}]}\end{array}$ & $\begin{array}{c}\text { Sequence } \\
\text { length } \\
{[A A]}\end{array}$ & Score & $\begin{array}{c}\text { Sequence } \\
\text { Coverage } \\
{[\%]}\end{array}$ & GI No. & $\begin{array}{c}\text { Accession No } \\
\text { [SwissProtKB/ } \\
\text { Swiss-Prot/ } \\
\text { S.cerevisiae] } \\
\text { (BLAST } \\
\text { Accession No) }\end{array}$ & $\begin{array}{l}\text { Subcellular } \\
\text { localization }\end{array}$ & Description & $\begin{array}{c}\text { Next match, } \\
\text { GI No. } \\
\text { (score) }\end{array}$ \\
\hline $41^{\mathrm{DB}}$ & ENO2 & 46.94 & 5.67 & 437 & 196 & 16 & gi|6321968 & NP_012044 & Cytoplasm & $\begin{array}{c}\text { Enolase II, a } \\
\text { phosphopyruvate } \\
\text { hydratase that catalyzes } \\
\text { the conversion of 2- } \\
\text { phosphoglycerate to } \\
\text { phosphoenolpyruvate } \\
\text { during glycolysis and the } \\
\text { reverse reaction during } \\
\text { gluconeogenesis; } \\
\text { expression is induced in } \\
\text { response to glucose. }\end{array}$ & $\begin{array}{c}\text { AWRI1631 } \\
133840, \\
\text { gi|20734212 } \\
2(24)\end{array}$ \\
\hline $42^{\mathrm{DB}}$ & ENO2 & 46.94 & 5.67 & 437 & 146 & 8 & gi|6321968 & NP_012044 & Cytoplasm & $\begin{array}{c}\text { Enolase II, a } \\
\text { phosphopyruvate } \\
\text { hydratase that catalyzes } \\
\text { the conversion of 2- } \\
\text { phosphoglycerate to } \\
\text { phosphoenolpyruvate } \\
\text { during glycolysis and the } \\
\text { reverse reaction during } \\
\text { gluconeogenesis; } \\
\text { expression is induced in } \\
\text { response to glucose. }\end{array}$ & $\begin{array}{c}\text { Ics2p, } \\
\text { gi|30267748 } \\
(30)\end{array}$ \\
\hline
\end{tabular}




\begin{tabular}{|c|c|c|c|c|c|c|c|c|c|c|c|}
\hline $\begin{array}{l}\text { Spot } \\
\text { No }\end{array}$ & $\begin{array}{l}\text { Gene } \\
\text { name }\end{array}$ & $\begin{array}{l}\text { Mass } \\
{[\mathrm{kDa}]}\end{array}$ & $\begin{array}{c}\mathrm{p} / \\
{[\mathrm{pH}]}\end{array}$ & $\begin{array}{c}\text { Sequence } \\
\text { length } \\
{[A A]}\end{array}$ & Score & $\begin{array}{c}\text { Sequence } \\
\text { Coverage } \\
{[\%]}\end{array}$ & GI No. & $\begin{array}{c}\text { Accession No } \\
\text { [SwissProtKB/ } \\
\text { Swiss-Prot/ } \\
\text { S.cerevisiae] } \\
\text { (BLAST } \\
\text { Accession No) }\end{array}$ & $\begin{array}{l}\text { Subcellular } \\
\text { localization }\end{array}$ & Description & $\begin{array}{c}\text { Next match, } \\
\text { GI No. } \\
\text { (score) }\end{array}$ \\
\hline $51^{1 \mathrm{~B}}$ & ENO2 & 46.94 & 5.67 & 437 & 139 & 15 & gi|6321968 & NP_012044 & Cytoplasm & $\begin{array}{c}\text { Enolase II, a } \\
\text { phosphopyruvate } \\
\text { hydratase that catalyzes } \\
\text { the conversion of 2- } \\
\text { phosphoglycerate to } \\
\text { phosphoenolpyruvate } \\
\text { during glycolysis and the } \\
\text { reverse reaction during } \\
\text { gluconeogenesis; } \\
\text { expression is induced in } \\
\text { response to glucose. }\end{array}$ & $\begin{array}{c}\text { Chain A, } \\
\text { Mata1MATA } \\
\text { LPHA2-3a } \\
\text { Heterodimer } \\
\text { Bound To } \\
\text { DNA, } \\
\text { gi|21466066 } \\
\text { (42) }\end{array}$ \\
\hline $162^{\mathrm{D}}$ & ENO2 & 46.94 & 5.67 & 437 & 130 & 33 & gi|6321968 & NP_012044 & Cytoplasm & $\begin{array}{c}\text { Enolase II, a } \\
\text { phosphopyruvate } \\
\text { hydratase that catalyzes } \\
\text { the conversion of 2- } \\
\text { phosphoglycerate to } \\
\text { phosphoenolpyruvate } \\
\text { during glycolysis and the } \\
\text { reverse reaction during } \\
\text { gluconeogenesis; } \\
\text { expression is induced in } \\
\text { response to glucose. }\end{array}$ & $\begin{array}{c}\text { Hypothetical } \\
\text { protein } \\
\text { YDL124W, } \\
\text { gi|6320079 } \\
\text { (49) }\end{array}$ \\
\hline
\end{tabular}




\begin{tabular}{|c|c|c|c|c|c|c|c|c|c|c|c|}
\hline $\begin{array}{l}\text { Spot } \\
\text { No }\end{array}$ & $\begin{array}{l}\text { Gene } \\
\text { name }\end{array}$ & $\begin{array}{l}\text { Mass } \\
{[k D a]}\end{array}$ & $\begin{array}{c}\mathrm{p} / \\
{[\mathrm{pH}]}\end{array}$ & $\begin{array}{c}\text { Sequence } \\
\text { length } \\
{[A A]}\end{array}$ & Score & $\begin{array}{c}\text { Sequence } \\
\text { Coverage } \\
{[\%]}\end{array}$ & GI No. & $\begin{array}{c}\text { Accession No } \\
\text { [SwissProtKB/ } \\
\text { Swiss-Prot/ } \\
\text { S.cerevisiae] } \\
\text { (BLAST } \\
\text { Accession No) }\end{array}$ & $\begin{array}{l}\text { Subcellular } \\
\text { localization }\end{array}$ & Description & $\begin{array}{l}\text { Next match, } \\
\text { GI No. } \\
\text { (score) }\end{array}$ \\
\hline $35^{\mathrm{DB}}$ & ENO2 & 46.94 & 5.67 & 437 & 68 & 21 & gi|6321968 & NP_012044 & Cytoplasm & $\begin{array}{c}\text { Enolase II, a } \\
\text { phosphopyruvate } \\
\text { hydratase that catalyzes } \\
\text { the conversion of 2- } \\
\text { phosphoglycerate to } \\
\text { phosphoenolpyruvate } \\
\text { during glycolysis and the } \\
\text { reverse reaction during } \\
\text { gluconeogenesis; } \\
\text { expression is induced in } \\
\text { response to glucose. }\end{array}$ & $\begin{array}{c}\text { Tal1p, } \\
\text { gi|6323386 } \\
(42)\end{array}$ \\
\hline $120^{\mathrm{D}}$ & $F B A 1$ & 39.88 & 5.51 & 359 & 128 & 15 & gi|6322790 & NP_012863 & $\begin{array}{l}\text { Cytoplasm } \\
\text { Mitochondrion }\end{array}$ & $\begin{array}{l}\text { Fructose-1,6- } \\
\text { bisphosphate aldolase, } \\
\text { required for glycolysis and } \\
\text { gluconeogenesis; } \\
\text { catalyzes conversion of } \\
\text { fructose-1,6-bisphosphate } \\
\text { to glyceraldehyde-3-P and } \\
\text { dihydroxyacetone-P; } \\
\text { locates to mitochondrial } \\
\text { outer surface upon } \\
\text { oxidative stress. }\end{array}$ & $\begin{array}{c}\text { Acp 1p, } \\
\text { gi|6322656 } \\
(30)\end{array}$ \\
\hline $98^{\mathrm{DA}}$ & FPR1 & 12.07 & 5.71 & 113 & 185 & 45 & gi|157834293 & $\begin{array}{c}\text { 1YAT_A } \\
\text { (NP_014264) }\end{array}$ & Cytoplasm & $\begin{array}{c}\text { Chain A, Improved } \\
\text { Calcineurin Inhibition By } \\
\text { Yeast Fkbp12-Drug } \\
\text { Complexes }\end{array}$ & $\begin{array}{c}\text { Kelch } \\
\text { repeat- } \\
\text { containing } \\
\text { protein 1, } \\
\text { gi|19040593 } \\
6(35)\end{array}$ \\
\hline
\end{tabular}




\begin{tabular}{|c|c|c|c|c|c|c|c|c|c|c|c|}
\hline $\begin{array}{l}\text { Spot } \\
\text { No }\end{array}$ & $\begin{array}{l}\text { Gene } \\
\text { name }\end{array}$ & $\begin{array}{l}\text { Mass } \\
{[\mathrm{kDa}]}\end{array}$ & $\begin{array}{c}\mathrm{pl} \\
{[\mathrm{pH}]}\end{array}$ & $\begin{array}{c}\text { Sequence } \\
\text { length } \\
{[A A]}\end{array}$ & Score & $\begin{array}{c}\text { Sequence } \\
\text { Coverage } \\
{[\%]}\end{array}$ & GI No. & $\begin{array}{c}\text { Accession No } \\
\text { [SwissProtKB/ } \\
\text { Swiss-Prot/ } \\
\text { S.cerevisiae] } \\
\text { (BLAST } \\
\text { Accession No) }\end{array}$ & $\begin{array}{l}\text { Subcellular } \\
\text { localization }\end{array}$ & Description & $\begin{array}{l}\text { Next match, } \\
\text { GI No. } \\
\text { (score) }\end{array}$ \\
\hline $157^{\prime}$ & FUR1 & 24.86 & 5.58 & 216 & 280 & 60 & gi|37362660 & NP_011996 & Intracellular & $\begin{array}{l}\text { Uracil phosphoribosyl } \\
\text { transferase, synthesizes } \\
\text { UMP from uracil; involved } \\
\text { in the pyrimidine salvage } \\
\text { pathway. }\end{array}$ & $\begin{array}{l}\text { YNR045Wp- } \\
\text { like protein, } \\
\text { gi|20734154 } \\
1(32)\end{array}$ \\
\hline $77^{\mathrm{IB}}$ & $G D H 1$ & 49.89 & 5.55 & 453 & 129 & 22 & gi|171594 & $\begin{array}{c}\text { AAA34642 } \\
\text { (NP_015020) }\end{array}$ & $\begin{array}{l}\text { Cytoplasm } \\
\text { Nucleus }\end{array}$ & $\begin{array}{c}\text { Glutamate } \\
\text { dehydrogenase. }\end{array}$ & $\begin{array}{c}\text { AWRI1631_ } \\
41590, \\
\text { gi|20734697 } \\
5(26)\end{array}$ \\
\hline $76^{\mathrm{IB}}$ & $G D H 1$ & 49.89 & 5.55 & 453 & 68 & 22 & gi|171594 & $\begin{array}{c}\text { AAA34642 } \\
\left(\mathrm{NP} \_015020\right)\end{array}$ & $\begin{array}{l}\text { Cytoplasm } \\
\text { Nucleus }\end{array}$ & $\begin{array}{c}\text { Glutamate } \\
\text { dehydrogenase }\end{array}$ & $(-)$ \\
\hline $221^{B}$ & $G L K 1$ & 55.74 & 5.8 & 500 & 93 & 28 & gi|6319809 & NP_009890 & $\begin{array}{l}\text { Cytoplasm } \\
\text { Plasma } \\
\text { membrane }\end{array}$ & $\begin{array}{l}\text { Glucokinase catalyzes the } \\
\text { phosphorylation of } \\
\text { glucose at C6 in the first } \\
\text { irreversible step of } \\
\text { glucose metabolism; one } \\
\text { of three glucose } \\
\text { phosphorylating enzymes; } \\
\text { expression regulated by } \\
\text { non-fermentable carbon } \\
\text { sources. }\end{array}$ & $(-)$ \\
\hline
\end{tabular}




\begin{tabular}{|c|c|c|c|c|c|c|c|c|c|c|c|}
\hline $\begin{array}{l}\text { Spot } \\
\text { No }\end{array}$ & $\begin{array}{l}\text { Gene } \\
\text { name }\end{array}$ & $\begin{array}{l}\text { Mass } \\
{[\mathrm{kDa}]}\end{array}$ & $\begin{array}{c}\mathrm{pl} \\
{[\mathrm{pH}]}\end{array}$ & $\begin{array}{l}\text { Sequence } \\
\text { length } \\
{[\mathrm{AA}]}\end{array}$ & Score & $\begin{array}{c}\text { Sequence } \\
\text { Coverage } \\
{[\%]}\end{array}$ & GI No. & $\begin{array}{c}\text { Accession No } \\
\text { [SwissProtKB/ } \\
\text { Swiss-Prot/ } \\
\text { S.cerevisiae] } \\
\text { (BLAST } \\
\text { Accession No) }\end{array}$ & $\begin{array}{l}\text { Subcellular } \\
\text { localization }\end{array}$ & Description & $\begin{array}{l}\text { Next match, } \\
\text { GI No. } \\
\text { (score) }\end{array}$ \\
\hline $34^{\mathrm{B}}$ & GLN1 & 42.13 & 5.92 & 370 & 83 & 18 & gi|417061 & $\begin{array}{c}\text { P32288 } \\
\text { (NP_015360.2) }\end{array}$ & Cytoplasm & $\begin{array}{l}\text { Glutamine synthetase } \\
\text { (GS), synthesizes } \\
\text { glutamine from glutamate } \\
\text { and ammonia; with Glt1p, } \\
\text { forms the secondary } \\
\text { pathway for glutamate } \\
\text { biosynthesis from } \\
\text { ammonia; expression } \\
\text { regulated by nitrogen } \\
\text { source and by amino acid } \\
\text { limitation. }\end{array}$ & $(-)$ \\
\hline $16^{\mathrm{B}}$ & GND1 & 54.91 & 6.44 & 497 & 598 & 29 & gi|157835612 & $\begin{array}{c}\text { 2P4Q_A } \\
\left(\mathrm{NP} \_012053\right)\end{array}$ & Cytoplasm & Chain A, Gnd1. & $\begin{array}{c}\text { YPL083Cp- } \\
\text { like protein, } \\
\text { gi|20734053 } \\
4(30)\end{array}$ \\
\hline $24^{\mathrm{IB}}$ & GUA1 & 58.73 & 6.05 & 525 & 128 & 16 & gi|6323873 & NP_013944 & Cytoplasm & $\begin{array}{l}\text { GMP synthase, an } \\
\text { enzyme that catalyzes the } \\
\text { second step in the } \\
\text { biosynthesis of GMP from } \\
\text { inosine } 5 \text { '-phosphate } \\
\text { (IMP); transcription is not } \\
\text { subject to regulation by } \\
\text { guanine but is negatively } \\
\text { regulated by nutrient } \\
\text { starvation. }\end{array}$ & $\begin{array}{c}\text { Cdc19p, } \\
\text { gi|6319279 } \\
(59)\end{array}$ \\
\hline
\end{tabular}




\begin{tabular}{|c|c|c|c|c|c|c|c|c|c|c|c|}
\hline $\begin{array}{l}\text { Spot } \\
\text { No }\end{array}$ & $\begin{array}{l}\text { Gene } \\
\text { name }\end{array}$ & $\begin{array}{l}\text { Mass } \\
{[\mathrm{kDa}]}\end{array}$ & $\begin{array}{c}\mathrm{pl} \\
{[\mathrm{pH}]}\end{array}$ & $\begin{array}{c}\text { Sequence } \\
\text { length } \\
{[A A]}\end{array}$ & Score & $\begin{array}{c}\text { Sequence } \\
\text { Coverage } \\
{[\%]}\end{array}$ & GI No. & $\begin{array}{c}\text { Accession No } \\
\text { [SwissProtKB/ } \\
\text { Swiss-Prot/ } \\
\text { S.cerevisiae] } \\
\text { (BLAST } \\
\text { Accession No) }\end{array}$ & $\begin{array}{l}\text { Subcellular } \\
\text { localization }\end{array}$ & Description & $\begin{array}{l}\text { Next match, } \\
\text { GI No. } \\
\text { (score) }\end{array}$ \\
\hline $12^{\mathrm{IB}}$ & HOM2 & 40.03 & 6.27 & 365 & 88 & 26 & gi|6320362 & NP_010442 & $\begin{array}{c}\text { Cytoplasm } \\
\text { Nucleus } \\
\text { Plasma } \\
\text { membrane }\end{array}$ & $\begin{array}{l}\text { Aspartic beta semi- } \\
\text { aldehyde dehydrogenase } \\
\text { catalyzes the second step } \\
\text { in the common pathway } \\
\text { for methionine and } \\
\text { threonine biosynthesis; } \\
\text { expression regulated by } \\
\text { Gcn4p and the general } \\
\text { control of amino acid } \\
\text { synthesis. }\end{array}$ & $\begin{array}{c}\text { Alcohol } \\
\text { dehydrogen } \\
\text { ase isozyme } \\
\text { I, gi|223142 } \\
\text { (59) }\end{array}$ \\
\hline $119^{\mathrm{B}}$ & $H R / 1$ & 27.54 & 5.1 & 244 & 163 & 26 & gi|6323332 & NP_013404 & $\begin{array}{l}\text { Cytoplasm } \\
\text { Nucleus }\end{array}$ & $\begin{array}{l}\text { Interacts with HRR25. } \\
\text { May interact with SEC72. }\end{array}$ & $\begin{array}{l}\text { Unnamed } \\
\text { protein } \\
\text { product, } \\
\text { gi|4291 (42) }\end{array}$ \\
\hline $176^{D}$ & HSC82 & 80.82 & 4.76 & 705 & 591 & 22 & gi|171723 & $\begin{array}{c}\text { AAA02813 } \\
\text { (NP_013911) }\end{array}$ & $\begin{array}{l}\text { Cytoplasm } \\
\text { Mitochondrion }\end{array}$ & Hsc82 protein. & $\begin{array}{c}\text { Bdh2p, } \\
\text { gi|6319257 } \\
\text { (33) }\end{array}$ \\
\hline $228^{\prime}$ & HSP104 & $\begin{array}{c}102.4 \\
6\end{array}$ & 5.62 & 908 & 94 & 16 & gi|228154 & $\begin{array}{c}\text { 1717391A } \\
\left(\mathrm{NP} \_013074\right)\end{array}$ & $\begin{array}{l}\text { Cytoplasm } \\
\text { Nucleus }\end{array}$ & Protein Hsp104. & $\begin{array}{c}\text { Pau9p, } \\
\text { gi|13129151 } \\
\text { (35) }\end{array}$ \\
\hline
\end{tabular}




\begin{tabular}{|c|c|c|c|c|c|c|c|c|c|c|c|}
\hline $\begin{array}{l}\text { Spot } \\
\text { No }\end{array}$ & $\begin{array}{l}\text { Gene } \\
\text { name }\end{array}$ & $\begin{array}{l}\text { Mass } \\
{[k D a]}\end{array}$ & $\begin{array}{c}\mathrm{p} / \\
{[\mathrm{pH}]}\end{array}$ & $\begin{array}{l}\text { Sequence } \\
\text { length } \\
{[A A]}\end{array}$ & Score & $\begin{array}{c}\text { Sequence } \\
\text { Coverage } \\
{[\%]}\end{array}$ & GI No. & $\begin{array}{c}\text { Accession No } \\
\text { [SwissProtKB/ } \\
\text { Swiss-Prot/ } \\
\text { S.cerevisiae] } \\
\text { (BLAST } \\
\text { Accession No) }\end{array}$ & $\begin{array}{l}\text { Subcellular } \\
\text { localization }\end{array}$ & Description & $\begin{array}{l}\text { Next match, } \\
\text { GI No. } \\
\text { (score) }\end{array}$ \\
\hline $125^{1}$ & HSP26 & 23.86 & 5.31 & 214 & 58 & 31 & gi|6319546 & NP_009628 & $\begin{array}{l}\text { Cytoplasm } \\
\text { Nucleus }\end{array}$ & $\begin{array}{l}\text { Small heat shock protein } \\
\text { (sHSP) with chaperone } \\
\text { activity; forms hollow, } \\
\text { sphere-shaped oligomers } \\
\text { that suppress unfolded } \\
\text { proteins aggregation; } \\
\text { oligomer activation } \\
\text { requires heat-induced } \\
\text { conformational change; } \\
\text { also has mRNA binding } \\
\text { activity. }\end{array}$ & $\begin{array}{c}\text { Mrpl38p, } \\
\text { gi|6322678 } \\
(23)\end{array}$ \\
\hline $168^{\mathrm{A}}$ & HSP6O & 60.99 & 5.23 & 572 & 114 & 25 & gil6323288 & NP_013360 & $\begin{array}{l}\text { Mitochondrion } \\
\text { matrix }\end{array}$ & $\begin{array}{l}\text { Tetradecameric } \\
\text { mitochondrial chaperonin } \\
\text { required for ATP- } \\
\text { dependent folding of } \\
\text { precursor polypeptides } \\
\text { and complex assembly; } \\
\text { prevents aggregation and } \\
\text { mediates protein refolding } \\
\text { after heat shock; role in } \\
\text { mtDNA transmission; } \\
\text { phosphorylated. }\end{array}$ & $\begin{array}{c}\text { Conserved } \\
\text { protein, } \\
\text { gi|15194375 } \\
7(24)\end{array}$ \\
\hline $175^{\prime}$ & HSP82 & 77.92 & 5.06 & 677 & 344 & 15 & gi|99031945 & $\begin{array}{c}\text { 2CG9_A } \\
\left(N P \_015084\right)\end{array}$ & Cytoplasm & $\begin{array}{c}\text { Chain A, Hsp90-Sba1 } \\
\text { closed chaperone } \\
\text { complex. }\end{array}$ & $\begin{array}{l}\text { YNR045Wp- } \\
\text { like protein, } \\
\text { gi|20734154 } \\
1 \text { (29) }\end{array}$ \\
\hline $174^{\prime}$ & HSP82 & 77.92 & 5.06 & 677 & 109 & 10 & gi|99031945 & $\begin{array}{c}\text { 2CG9_A } \\
\text { (NP_015084) }\end{array}$ & Cytoplasm & $\begin{array}{l}\text { Chain A, Hsp90-Sba1 } \\
\text { closed chaperone } \\
\text { complex. }\end{array}$ & $(-)$ \\
\hline
\end{tabular}




\begin{tabular}{|c|c|c|c|c|c|c|c|c|c|c|c|}
\hline $\begin{array}{l}\text { Spot } \\
\text { No }\end{array}$ & $\begin{array}{l}\text { Gene } \\
\text { name }\end{array}$ & $\begin{array}{l}\text { Mass } \\
{[\mathrm{kDa}]}\end{array}$ & $\begin{array}{c}\mathrm{p} / \\
{[\mathrm{pH}]}\end{array}$ & $\begin{array}{l}\text { Sequence } \\
\text { length } \\
{[A A]}\end{array}$ & Score & $\begin{array}{c}\text { Sequence } \\
\text { Coverage } \\
{[\%]}\end{array}$ & GI No. & $\begin{array}{c}\text { Accession No } \\
\text { [SwissProtKB/ } \\
\text { Swiss-Prot/ } \\
\text { S.cerevisiae] } \\
\text { (BLAST } \\
\text { Accession No) }\end{array}$ & $\begin{array}{l}\text { Subcellular } \\
\text { localization }\end{array}$ & Description & $\begin{array}{l}\text { Next match, } \\
\text { GI No. } \\
\text { (score) }\end{array}$ \\
\hline $187^{\mathrm{B}}$ & $H X K 2$ & 54.13 & 5.16 & 486 & 226 & 35 & gi|6321184 & NP_011261 & $\begin{array}{l}\text { Cytoplasm } \\
\text { Mitochondrion } \\
\text { Nucleus }\end{array}$ & $\begin{array}{l}\text { Hexokinase } 2 \text { catalyzes } \\
\text { phosphorylation of } \\
\text { glucose in the Cytoplasm; } \\
\text { predominant hexokinase } \\
\text { during growth on glucose; } \\
\text { functions in the nucleus to } \\
\text { repress expression of } \\
\text { HXK1 and GLK1 and to } \\
\text { induce expression of its } \\
\text { own gene }\end{array}$ & $\begin{array}{c}\text { Stress- } \\
\text { seventy } \\
\text { subfamily A } \\
\text { protein, } \\
\text { gi|15194114 } \\
6(173)\end{array}$ \\
\hline 82 & $H X K 2$ & 54.16 & 5.16 & 486 & 83 & 24 & gi|3793 & CAA27203 & $\begin{array}{l}\text { Cytoplasm } \\
\text { Mitochondrion } \\
\text { Nucleus }\end{array}$ & $\begin{array}{l}\text { Hexokinase } 2 \text { catalyzes } \\
\text { phosphorylation of } \\
\text { glucose in the Cytoplasm; } \\
\text { predominant hexokinase } \\
\text { during growth on glucose; } \\
\text { functions in the nucleus to } \\
\text { repress expression of } \\
\text { HXK1 and GLK1 and to } \\
\text { induce expression of its } \\
\text { own gene. }\end{array}$ & $(-)$ \\
\hline
\end{tabular}




\begin{tabular}{|c|c|c|c|c|c|c|c|c|c|c|c|}
\hline $\begin{array}{l}\text { Spot } \\
\text { No }\end{array}$ & $\begin{array}{l}\text { Gene } \\
\text { name }\end{array}$ & $\begin{array}{l}\text { Mass } \\
{[\mathrm{kDa}]}\end{array}$ & $\begin{array}{c}\mathrm{p} / \\
{[\mathrm{pH}]}\end{array}$ & $\begin{array}{l}\text { Sequence } \\
\text { length } \\
{[A A]}\end{array}$ & Score & $\begin{array}{c}\text { Sequence } \\
\text { Coverage } \\
{[\%]}\end{array}$ & GI No. & $\begin{array}{c}\text { Accession No } \\
\text { [SwissProtKB/ } \\
\text { Swiss-Prot/ } \\
\text { S.cerevisiae] } \\
\text { (BLAST } \\
\text { Accession No) }\end{array}$ & $\begin{array}{l}\text { Subcellular } \\
\text { localization }\end{array}$ & Description & $\begin{array}{c}\text { Next match, } \\
\text { GI No. } \\
\text { (score) }\end{array}$ \\
\hline 178 & KAR2 & 74.47 & 4.79 & 682 & 432 & 24 & gi|6322426 & NP_012500 & ER lumen & $\begin{array}{l}\text { ATPase involved in } \\
\text { protein import into the ER, } \\
\text { also acts as a chaperone } \\
\text { to mediate protein folding } \\
\text { in the ER and may play a } \\
\text { role in ER export of } \\
\text { soluble proteins; regulates } \\
\text { the unfolded protein } \\
\text { response via interaction } \\
\text { with Ire1p. }\end{array}$ & $(-)$ \\
\hline $222^{\mathrm{IB}}$ & LYS21 & 49.02 & 5.88 & 440 & 61 & 17 & gi|6320071 & NP_010151 & Mitochondrion & $\begin{array}{l}\text { Homocitrate synthase } \\
\text { isozyme, catalyzes the } \\
\text { condensation of acetyl- } \\
\text { CoA and alpha- } \\
\text { ketoglutarate to form } \\
\text { homocitrate, which is the } \\
\text { first step in the lysine } \\
\text { biosynthesis pathway; } \\
\text { highly similar to the other } \\
\text { isozyme, Lys20p. }\end{array}$ & $(-)$ \\
\hline
\end{tabular}




\begin{tabular}{|c|c|c|c|c|c|c|c|c|c|c|c|}
\hline $\begin{array}{l}\text { Spot } \\
\text { No }\end{array}$ & $\begin{array}{l}\text { Gene } \\
\text { name }\end{array}$ & $\begin{array}{l}\text { Mass } \\
{[\mathrm{kDa}]}\end{array}$ & $\begin{array}{c}\mathrm{pl} \\
{[\mathrm{pH}]}\end{array}$ & $\begin{array}{l}\text { Sequence } \\
\text { length } \\
{[\mathrm{AA}]}\end{array}$ & Score & $\begin{array}{c}\text { Sequence } \\
\text { Coverage } \\
{[\%]}\end{array}$ & GI No. & $\begin{array}{c}\text { Accession No } \\
\text { [SwissProtKB/ } \\
\text { Swiss-Prot/ } \\
\text { S.cerevisiae] } \\
\text { (BLAST } \\
\text { Accession No) }\end{array}$ & $\begin{array}{l}\text { Subcellular } \\
\text { localization }\end{array}$ & Description & $\begin{array}{l}\text { Next match, } \\
\text { GI No. } \\
\text { (score) }\end{array}$ \\
\hline $18^{\mathrm{IB}}$ & OYE2 & 44.98 & 6.13 & 400 & 88 & 25 & gi|6321973 & NP_012049 & $\begin{array}{l}\text { Cytoplasm } \\
\text { Mitochondrion } \\
\text { Nucleus }\end{array}$ & $\begin{array}{l}\text { Conserved NADPH } \\
\text { oxidoreductase containing } \\
\text { flavin mononucleotide } \\
\text { (FMN), homologous to } \\
\text { Oye3p with different } \\
\text { ligand binding and } \\
\text { catalytic properties; may } \\
\text { be involved in sterol } \\
\text { metabolism, oxidative } \\
\text { stress response, and } \\
\text { programmed cell death. }\end{array}$ & $(-)$ \\
\hline $155^{\mathrm{IB}}$ & PAA1 & 22.04 & 5.58 & 191 & 169 & 12 & gi|6320276 & NP_010356 & Cytoplasm & $\begin{array}{c}\text { Polyamine } \\
\text { acetyltransferase; } \\
\text { acetylates polyamines } \\
\text { (e.g. putrescine, } \\
\text { spermidine, spermine) } \\
\text { and also aralkylamines } \\
\text { (e.g. tryptamine, } \\
\text { phenylethylamine); may } \\
\text { be involved in } \\
\text { transcription and/or DNA } \\
\text { replication }\end{array}$ & $\begin{array}{c}\text { Tif2p, } \\
\text { gi|6322323 } \\
\text { (39) }\end{array}$ \\
\hline
\end{tabular}




\begin{tabular}{|c|c|c|c|c|c|c|c|c|c|c|c|}
\hline $\begin{array}{l}\text { Spot } \\
\text { No }\end{array}$ & $\begin{array}{l}\text { Gene } \\
\text { name }\end{array}$ & $\begin{array}{l}\text { Mass } \\
{[\mathrm{kDa}]}\end{array}$ & $\begin{array}{c}\mathrm{p} / \\
{[\mathrm{pH}]}\end{array}$ & $\begin{array}{l}\text { Sequence } \\
\text { length } \\
{[A A]}\end{array}$ & Score & $\begin{array}{c}\text { Sequence } \\
\text { Coverage } \\
{[\%]}\end{array}$ & GI No. & $\begin{array}{c}\text { Accession No } \\
\text { [SwissProtKB/ } \\
\text { Swiss-Prot/ } \\
\text { S.cerevisiae] } \\
\text { (BLAST } \\
\text { Accession No) }\end{array}$ & $\begin{array}{l}\text { Subcellular } \\
\text { localization }\end{array}$ & Description & $\begin{array}{l}\text { Next match, } \\
\text { GI No. } \\
\text { (score) }\end{array}$ \\
\hline $217^{D}$ & $P D C 1$ & 61.68 & 5.8 & 563 & 190 & 28 & gi|6323073 & NP_013145 & $\begin{array}{l}\text { Cytoplasm } \\
\text { Nucleus }\end{array}$ & $\begin{array}{c}\text { Major of three pyruvate } \\
\text { decarboxylase isozymes, } \\
\text { key enzyme in alcoholic } \\
\text { fermentation, } \\
\text { decarboxylates pyruvate } \\
\text { to acetaldehyde; subject } \\
\text { to glucose-, ethanol-, and } \\
\text { autoregulation; involved in } \\
\text { amino acid catabolism. }\end{array}$ & $\begin{array}{l}\text { YGR087Cp- } \\
\text { like protein, } \\
\text { gi|20734515 } \\
\quad 1(55)\end{array}$ \\
\hline $218^{D}$ & $P D C 1$ & 61.68 & 5.8 & 563 & 370 & 18 & gi|7245976 & $\begin{array}{c}\text { 1QPB_A } \\
\text { (NP_013145) }\end{array}$ & $\begin{array}{l}\text { Cytoplasm } \\
\text { Nucleus }\end{array}$ & $\begin{array}{c}\text { Chain A, Pyruvate } \\
\text { decarboyxlase (Form B) } \\
\text { complexed with } \\
\text { pyruvamide. }\end{array}$ & $(-)$ \\
\hline $215^{B}$ & $P D C 1$ & 61.68 & 5.8 & 563 & 135 & 11 & gi|7245976 & $\begin{array}{c}\text { 1QPB_A } \\
\text { (NP_013145) }\end{array}$ & $\begin{array}{l}\text { Cytoplasm } \\
\text { Nucleus }\end{array}$ & $\begin{array}{c}\text { Chain A, Pyruvate } \\
\text { decarboxylase complexed } \\
\text { with pyruvamide. }\end{array}$ & $(-)$ \\
\hline$\underset{B}{219^{D}}$ & $P D C 1$ & 61.68 & 5.8 & 563 & 117 & 15 & gi|7245976 & $\begin{array}{c}\text { 1QPB_A } \\
\text { (NP_013145) }\end{array}$ & $\begin{array}{l}\text { Cytoplasm } \\
\text { Nucleus }\end{array}$ & $\begin{array}{l}\text { Chain A, Pyruvate } \\
\text { decarboxylase complexed } \\
\text { with pyruvamide. }\end{array}$ & $\begin{array}{l}\text { Unnamed } \\
\text { protein } \\
\text { product, } \\
\text { gi|4114 (42) }\end{array}$ \\
\hline $27^{\mathrm{DB}}$ & $P D C 1$ & 61.68 & 5.8 & 563 & 110 & 15 & gi|7245976 & $\begin{array}{c}\text { 1QPB_A } \\
(\mathrm{NP} \text { _013145) }\end{array}$ & $\begin{array}{l}\text { Cytoplasm } \\
\text { Nucleus }\end{array}$ & $\begin{array}{c}\text { Chain A, Pyruvate } \\
\text { decarboxylase complexed } \\
\text { with pyruvamide. }\end{array}$ & $(-)$ \\
\hline $216^{D}$ & $P D C 1$ & 61.68 & 5.8 & 563 & 80 & 8 & gi|7245976 & $\begin{array}{c}\text { 1QPB_A } \\
\text { (NP_013145) }\end{array}$ & $\begin{array}{l}\text { Cytoplasm } \\
\text { Nucleus }\end{array}$ & $\begin{array}{l}\text { Chain A, Pyruvate } \\
\text { decarboxylase complexed } \\
\text { with pyruvamide. }\end{array}$ & $(-)$ \\
\hline
\end{tabular}




\begin{tabular}{|c|c|c|c|c|c|c|c|c|c|c|c|}
\hline $\begin{array}{l}\text { Spot } \\
\text { No }\end{array}$ & $\begin{array}{l}\text { Gene } \\
\text { name }\end{array}$ & $\begin{array}{l}\text { Mass } \\
{[k D a]}\end{array}$ & $\begin{array}{c}\mathrm{p} / \\
{[\mathrm{pH}]}\end{array}$ & $\begin{array}{l}\text { Sequence } \\
\text { length } \\
{[A A]}\end{array}$ & Score & $\begin{array}{c}\text { Sequence } \\
\text { Coverage } \\
{[\%]}\end{array}$ & GI No. & $\begin{array}{l}\text { Accession No } \\
\text { [SwissProtKB/ } \\
\text { Swiss-Prot/ } \\
\text { S.cerevisiae] } \\
\text { (BLAST } \\
\text { Accession No) }\end{array}$ & $\begin{array}{l}\text { Subcellular } \\
\text { localization }\end{array}$ & Description & $\begin{array}{l}\text { Next match, } \\
\text { GI No. } \\
\text { (score) }\end{array}$ \\
\hline $158^{\mathrm{IA}}$ & PDI1 & 56.67 & 4.38 & 504 & 172 & 26 & gi|88192228 & $\begin{array}{c}\text { 2B5E_A } \\
\text { (NP_009887) }\end{array}$ & ER lumen & $\begin{array}{l}\text { Chain A, Disulfide } \\
\text { isomerase. }\end{array}$ & $\begin{array}{l}\text { SCY_2605, } \\
\text { gi| } 15194323 \\
4(24)\end{array}$ \\
\hline $159^{\mathrm{IA}}$ & PDI1 & 56.67 & 4.38 & 504 & 149 & 21 & gi|88192228 & $\begin{array}{c}\text { 2B5E_A } \\
\text { (NP_009887) }\end{array}$ & ER lumen & $\begin{array}{c}\text { Chain A, Disulfide } \\
\text { Isomerase. }\end{array}$ & $\begin{array}{c}\text { Tex1p, } \\
\text { gi|6324076 } \\
(33)\end{array}$ \\
\hline $200^{\mathrm{IB}}$ & PFK2 & $\begin{array}{c}105.1 \\
3\end{array}$ & 6.09 & 959 & 71 & 7 & gi|172140 & $\begin{array}{c}\text { AAA34860 } \\
\left(\mathrm{NP} \_013932\right)\end{array}$ & Cytoplasm & $\begin{array}{l}\text { Phosphofructokinase, a } \\
\text { key regulatory enzyme in } \\
\text { glycolysis, catalyzes the } \\
\text { phosphorylation of } \\
\text { fructose-6-phosphate to } \\
\text { fructose-1,6-biphosphate. }\end{array}$ & $\begin{array}{l}\text { Ups3p, } \\
\text { gi|6320391 } \\
\text { (31) }\end{array}$ \\
\hline $13^{\mathrm{IB}}$ & $P G K 1$ & 44.6 & 6.73 & 415 & 167 & 16 & gi|157833610 & $\begin{array}{c}\text { 1QPG_A } \\
\text { (NP_009938) }\end{array}$ & Cytoplasm & $\begin{array}{l}\text { Chain A, 3- } \\
\text { Phosphoglycerate kinase, } \\
\text { mutation R65q. }\end{array}$ & $(-)$ \\
\hline $223^{\mathrm{IB}}$ & PMI40 & 48.44 & 5.66 & 429 & 235 & 14 & gi|6320839 & NP_010918 & Cytoplasm & $\begin{array}{l}\text { Mannose-6-phosphate } \\
\text { isomerase, catalyzes the } \\
\text { interconversion of } \\
\text { fructose-6-P and } \\
\text { mannose-6-P; required for } \\
\text { early steps in protein } \\
\text { mannosylation }\end{array}$ & $\begin{array}{l}\text { Enolase II, } \\
\text { gi|6321968 } \\
(82)\end{array}$ \\
\hline
\end{tabular}




\begin{tabular}{|c|c|c|c|c|c|c|c|c|c|c|c|}
\hline $\begin{array}{l}\text { Spot } \\
\text { No }\end{array}$ & $\begin{array}{l}\text { Gene } \\
\text { name }\end{array}$ & $\begin{array}{l}\text { Mass } \\
{[\mathrm{kDa}]}\end{array}$ & $\begin{array}{c}\mathrm{pl} \\
{[\mathrm{pH}]}\end{array}$ & $\begin{array}{c}\text { Sequence } \\
\text { length } \\
{[A A]}\end{array}$ & Score & $\begin{array}{c}\text { Sequence } \\
\text { Coverage } \\
{[\%]}\end{array}$ & GI No. & $\begin{array}{c}\text { Accession No } \\
\text { [SwissProtKB/ } \\
\text { Swiss-Prot/ } \\
\text { S.cerevisiae] } \\
\text { (BLAST } \\
\text { Accession No) }\end{array}$ & $\begin{array}{l}\text { Subcellular } \\
\text { localization }\end{array}$ & Description & $\begin{array}{c}\text { Next match, } \\
\text { GI No. } \\
\text { (score) }\end{array}$ \\
\hline $164^{\mathrm{D}}$ & PRB1 & 69.8 & 5.94 & 635 & 75 & 5 & gi|6320775 & NP_010854 & Vacuole & $\begin{array}{l}\text { Vacuolar proteinase B } \\
\text { (yscB), a serine protease } \\
\text { of the subtilisin family; } \\
\text { involved in protein } \\
\text { degradation in the } \\
\text { vacuole and required for } \\
\text { full protein degradation } \\
\text { during sporulation; activity } \\
\text { inhibited by Pbi2p. }\end{array}$ & $\begin{array}{c}\text { YGL002W, } \\
\text { gi|51013601 } \\
(29)\end{array}$ \\
\hline $30^{\mathrm{DB}}$ & PSA1 & 39.71 & 5.95 & 361 & 254 & 29 & gi|6320148 & NP_010228 & Cytoplasm & $\begin{array}{c}\text { GDP-mannose } \\
\text { pyrophosphorylase } \\
\text { (mannose-1-phosphate } \\
\text { guanyltransferase), } \\
\text { synthesizes GDP- } \\
\text { mannose from GTP and } \\
\text { mannose-1-phosphate in } \\
\text { cell wall biosynthesis; } \\
\text { required for normal cell } \\
\text { wall structure. }\end{array}$ & $\begin{array}{c}\text { Chain B, } \\
\text { Cytochrome } \\
\text { Bc1 } \\
\text { Complex } \\
(130)\end{array}$ \\
\hline $29^{\mathrm{DB}}$ & PSA1 & 39.71 & 5.95 & 361 & 172 & 19 & gi|6320148 & NP_010228 & Cytoplasm & $\begin{array}{c}\text { GDP-mannose } \\
\text { pyrophosphorylase } \\
\text { (mannose-1-phosphate } \\
\text { guanyltransferase), } \\
\text { synthesizes GDP- } \\
\text { mannose from GTP and } \\
\text { mannose-1-phosphate in } \\
\text { cell wall biosynthesis; } \\
\text { required for normal cell } \\
\text { wall structure }\end{array}$ & $\begin{array}{c}\text { Unknown } \\
\text { protein, } \\
\text { gi|808836 } \\
(36)\end{array}$ \\
\hline
\end{tabular}




\begin{tabular}{|c|c|c|c|c|c|c|c|c|c|c|c|}
\hline $\begin{array}{l}\text { Spot } \\
\text { No }\end{array}$ & $\begin{array}{l}\text { Gene } \\
\text { name }\end{array}$ & $\begin{array}{l}\text { Mass } \\
{[\mathrm{kDa}]}\end{array}$ & $\begin{array}{c}\mathrm{p} / \\
{[\mathrm{pH}]}\end{array}$ & $\begin{array}{l}\text { Sequence } \\
\text { length } \\
{[A A]}\end{array}$ & Score & $\begin{array}{c}\text { Sequence } \\
\text { Coverage } \\
{[\%]}\end{array}$ & GI No. & $\begin{array}{c}\text { Accession No } \\
\text { [SwissProtKB/ } \\
\text { Swiss-Prot/ } \\
\text { S.cerevisiae] } \\
\text { (BLAST } \\
\text { Accession No) }\end{array}$ & $\begin{array}{l}\text { Subcellular } \\
\text { localization }\end{array}$ & Description & $\begin{array}{l}\text { Next match, } \\
\text { GI No. } \\
\text { (score) }\end{array}$ \\
\hline $153^{\mathrm{IB}}$ & PST2 & 21.01 & 5.46 & 198 & 96 & 24 & gi|6320235 & NP_010315 & Secreted & $\begin{array}{c}\text { Protein with similarity to } \\
\text { members of a family of } \\
\text { flavodoxin-like proteins; } \\
\text { induced by oxidative } \\
\text { stress in a Yap1p } \\
\text { dependent manner; the } \\
\text { authentic, non-tagged } \\
\text { protein is detected in } \\
\text { highly purified } \\
\text { mitochondria in high- } \\
\text { throughut studies. }\end{array}$ & $\begin{array}{c}\text { Tsa1p, } \\
\text { gi|6323613 } \\
(49)\end{array}$ \\
\hline $161^{\prime}$ & RNA1 & 46.07 & 4.53 & 407 & 107 & 19 & gi|6323891 & NP_013962 & Cytoplasm & $\begin{array}{l}\text { GTPase activating protein } \\
\text { (GAP) for Gsp1p, involved } \\
\text { in nuclear transport. }\end{array}$ & $\begin{array}{l}\text { Ubiquitin } \\
\text { carboxyl- } \\
\text { terminal } \\
\text { hydrolase } 7 \text {, } \\
\text { gi|19040636 } \\
7(41)\end{array}$ \\
\hline $139^{\mathrm{IA}}$ & RPSOA & 20.37 & 9.66 & 185 & 100 & 27 & gi|49258822 & $\begin{array}{c}\text { 1S1H_B } \\
\left(\mathrm{NP} \_011730\right)\end{array}$ & Cytoplasm & $\begin{array}{l}\text { Chain B, Ribosomal 80s- } \\
\text { Eef2-Sordarin complex } \\
\text { obtained by docking } \\
\text { atomic models for RNA } \\
\text { and protein components } \\
\text { into a } 11.7 \text { A Cryo-Em } \\
\text { Map. }\end{array}$ & $\begin{array}{c}\text { Ics2p, } \\
\text { gi|302677448 } \\
\text { (19) }\end{array}$ \\
\hline
\end{tabular}




\begin{tabular}{|c|c|c|c|c|c|c|c|c|c|c|c|}
\hline $\begin{array}{l}\text { Spot } \\
\text { No }\end{array}$ & $\begin{array}{l}\text { Gene } \\
\text { name }\end{array}$ & $\begin{array}{l}\text { Mass } \\
{[\mathrm{kDa}]}\end{array}$ & $\begin{array}{c}\mathrm{pl} \\
{[\mathrm{pH}]}\end{array}$ & $\begin{array}{c}\text { Sequence } \\
\text { length } \\
{[A A]}\end{array}$ & Score & $\begin{array}{c}\text { Sequence } \\
\text { Coverage } \\
{[\%]}\end{array}$ & GI No. & $\begin{array}{c}\text { Accession No } \\
\text { [SwissProtKB/ } \\
\text { Swiss-Prot/ } \\
\text { S.cerevisiae] } \\
\text { (BLAST } \\
\text { Accession No) }\end{array}$ & $\begin{array}{l}\text { Subcellular } \\
\text { localization }\end{array}$ & Description & $\begin{array}{l}\text { Next match, } \\
\text { GI No. } \\
\text { (score) }\end{array}$ \\
\hline $104^{D}$ & RPS12 & 15.46 & 4.68 & 143 & 103 & 24 & gi|6324945 & NP_015014 & Cytoplasm & $\begin{array}{l}\text { Protein component of the } \\
\text { small (40S) ribosomal } \\
\text { subunit; has similarity to } \\
\text { rat ribosomal protein S12. }\end{array}$ & $\begin{array}{c}\text { Ptc1p, } \\
\text { gi|642800 } \\
(34)\end{array}$ \\
\hline $105^{\mathrm{D}}$ & RPS12 & 15.46 & 4.68 & 143 & 94 & 12 & gi|6324945 & NP_015014 & Cytoplasm & $\begin{array}{l}\text { Protein component of the } \\
\text { small (40S) ribosomal } \\
\text { subunit; has similarity to } \\
\text { rat ribosomal protein } \mathrm{S} 12 \text {. }\end{array}$ & $\begin{array}{c}\text { Predicted } \\
\text { protein, } \\
\text { gi|19040578 } \\
9(36)\end{array}$ \\
\hline $97^{\mathrm{DA}}$ & RPS21A & 9.79 & 5.76 & 87 & 88 & 74 & gi|6322910 & NP_012983 & Cytoplasm & $\begin{array}{l}\text { Protein component of the } \\
\text { small ( } 40 \mathrm{~S} \text { ) ribosomal } \\
\text { subunit; nearly identical to } \\
\text { Rps } 21 \mathrm{Bp} \text { and has } \\
\text { similarity to rat } \mathrm{S} 21 \\
\text { ribosomal protein. }\end{array}$ & $\begin{array}{c}\text { Eno2p, } \\
\text { gi|6321968 } \\
(70)\end{array}$ \\
\hline $7^{\mathrm{IA}}$ & RPS5 & 25.08 & 8.63 & 225 & 126 & 28 & gi|6322583 & NP_012657 & Cytoplasm & $\begin{array}{l}\text { Protein component of the } \\
\text { small ( } 40 S \text { ) ribosomal } \\
\text { subunit, the least basic of } \\
\text { the non-acidic ribosomal } \\
\text { proteins; phosphorylated } \\
\text { in vivo; essential for } \\
\text { viability; has similarity to } \\
\text { E. coli S7 and rat S5 } \\
\text { ribosomal proteins. }\end{array}$ & $\begin{array}{c}\text { Fmp25p, } \\
\text { gi|6323106 } \\
(35)\end{array}$ \\
\hline
\end{tabular}




\begin{tabular}{|c|c|c|c|c|c|c|c|c|c|c|c|}
\hline $\begin{array}{l}\text { Spot } \\
\text { No }\end{array}$ & $\begin{array}{l}\text { Gene } \\
\text { name }\end{array}$ & $\begin{array}{l}\text { Mass } \\
{[\mathrm{kDa}]}\end{array}$ & $\begin{array}{c}\mathrm{p} / \\
{[\mathrm{pH}]}\end{array}$ & $\begin{array}{c}\text { Sequence } \\
\text { length } \\
{[\mathrm{AA}]}\end{array}$ & Score & $\begin{array}{c}\text { Sequence } \\
\text { Coverage } \\
{[\%]}\end{array}$ & GI No. & $\begin{array}{c}\text { Accession No } \\
\text { [SwissProtKB/ } \\
\text { Swiss-Prot/ } \\
\text { S.cerevisiae] } \\
\text { (BLAST } \\
\text { Accession No) }\end{array}$ & $\begin{array}{l}\text { Subcellular } \\
\text { localization }\end{array}$ & Description & $\begin{array}{l}\text { Next match, } \\
\text { GI No. } \\
\text { (score) }\end{array}$ \\
\hline $95^{1}$ & RPT5 & 48.28 & 4.93 & 434 & 207 & 27 & gi|6324691 & NP_014760 & $\begin{array}{l}\text { Cytoplasm } \\
\text { Nucleus }\end{array}$ & $\begin{array}{l}\text { One of six ATPases of the } \\
\text { 19S regulatory particle of } \\
\text { the } 26 \mathrm{~S} \text { proteasome } \\
\text { involved in the } \\
\text { degradation of } \\
\text { ubiquitinated substrates; } \\
\text { recruited to the GAL1-10 } \\
\text { promoter region upon } \\
\text { induction of transcription; } \\
\text { similar to human TBP1 }\end{array}$ & $\begin{array}{c}\text { YOR117Wp- } \\
\text { like protein, } \\
\text { gi|20734115 } \\
3(198)\end{array}$ \\
\hline $36^{\mathrm{B}}$ & $S A H 1$ & 49.72 & 5.83 & 449 & 274 & 30 & gi|6320882 & NP_010961 & Cytoplasm & $\begin{array}{l}\text { S-adenosyl-L- } \\
\text { homocysteine hydrolase, } \\
\text { catabolizes S-adenosyl-L- } \\
\text { homocysteine, which is } \\
\text { formed after donation of } \\
\text { the activated methyl } \\
\text { group of S-adenosyl-L- } \\
\text { methionine (AdoMet) to } \\
\text { an acceptor. }\end{array}$ & $\begin{array}{c}\text { Silent } \\
\text { mating loci } \\
\text { repressor, } \\
\text { gi|15194164 } \\
1(30)\end{array}$ \\
\hline $86^{\prime}$ & SAM1 & 42.07 & 5.04 & 382 & 188 & 16 & gi|6323209 & NP_013281 & Cytoplasm & $\begin{array}{l}\text { S-adenosylmethionine } \\
\text { synthetase, catalyzes } \\
\text { transfer of the adenosyl } \\
\text { group of ATP to the sulfur } \\
\text { atom of methionine; one } \\
\text { of two differentially } \\
\text { regulated isozymes } \\
\text { (Sam1p and Sam2p). }\end{array}$ & $(-)$ \\
\hline
\end{tabular}




\begin{tabular}{|c|c|c|c|c|c|c|c|c|c|c|c|}
\hline $\begin{array}{l}\text { Spot } \\
\text { No }\end{array}$ & $\begin{array}{l}\text { Gene } \\
\text { name }\end{array}$ & $\begin{array}{l}\text { Mass } \\
{[\mathrm{kDa}]}\end{array}$ & $\begin{array}{c}\mathrm{p} / \\
{[\mathrm{pH}]}\end{array}$ & $\begin{array}{l}\text { Sequence } \\
\text { length } \\
{[A A]}\end{array}$ & Score & $\begin{array}{c}\text { Sequence } \\
\text { Coverage } \\
{[\%]}\end{array}$ & GI No. & $\begin{array}{c}\text { Accession No } \\
\text { [SwissProtKB/ } \\
\text { Swiss-Prot/ } \\
\text { S.cerevisiae] } \\
\text { (BLAST } \\
\text { Accession No) }\end{array}$ & $\begin{array}{l}\text { Subcellular } \\
\text { localization }\end{array}$ & Description & $\begin{array}{l}\text { Next match, } \\
\text { GI No. } \\
\text { (score) }\end{array}$ \\
\hline $118^{A}$ & SEC53 & 29.21 & 5.14 & 254 & 228 & 51 & gi|14318474 & NP_116609 & Cytoplasm & $\begin{array}{l}\text { Phosphomannomutase } \\
\text { involved in synthesis of } \\
\text { GDP-mannose and } \\
\text { dolichol-phosphate- } \\
\text { mannose; required for } \\
\text { folding and glycosylation } \\
\text { of secretory proteins in } \\
\text { the ER lumen. }\end{array}$ & $\begin{array}{c}\text { SCY } 2344, \\
\text { gi|15194415 } \\
9 \text { (39) }\end{array}$ \\
\hline $43^{\mathrm{IB}}$ & SOD1 & 15.85 & 5.48 & 153 & 264 & 60 & gi|6730103 & $\begin{array}{c}\text { 1B4T_A } \\
\text { (NP_012638) }\end{array}$ & $\begin{array}{c}\text { Cytoplasm } \\
\text { Mitochondrion } \\
\text { intermembrane } \\
\text { space }\end{array}$ & $\begin{array}{l}\text { Chain } \mathrm{A}, \mathrm{H} 48 \mathrm{c} \mathrm{Cu}(\mathrm{li}) \mathrm{Zn} \\
\text { superoxide dismutase. }\end{array}$ & $\begin{array}{l}\text { Unnamed } \\
\text { protein } \\
\text { product (40) }\end{array}$ \\
\hline 65 & SPE3 & 33.53 & 5.33 & 293 & 62 & 15 & gi|6325326 & NP_015394 & $\begin{array}{l}\text { Cytoplasm } \\
\text { Nucleus }\end{array}$ & $\begin{array}{l}\text { Spermidine synthase, } \\
\text { involved in biosynthesis of } \\
\text { spermidine and also in } \\
\text { biosynthesis of } \\
\text { pantothenic acid; } \\
\text { spermidine is required for } \\
\text { growth of wild-type cells. }\end{array}$ & $\begin{array}{l}\text { Tetrameric } \\
\text { tRNA } \\
\text { splicing } \\
\text { endonucleas } \\
\text { e } 54 \mathrm{kDa} \\
\text { subunit, } \\
\text { gi|19040787 } \\
2(36)\end{array}$ \\
\hline 93 & SRP1 & 59.46 & 4.8 & 530 & 126 & 14 & gi|58177142 & $\begin{array}{c}\text { 1WA5_B } \\
\text { (NP_014210) }\end{array}$ & $\begin{array}{l}\text { Cytoplasm } \\
\text { perinuclear } \\
\text { region }\end{array}$ & $\begin{array}{l}\text { Chain B, Exportin Cse1p } \\
\text { complexed with its cargo } \\
\text { (Kap60p) and Rangtp. }\end{array}$ & $(-)$ \\
\hline
\end{tabular}




\begin{tabular}{|c|c|c|c|c|c|c|c|c|c|c|c|}
\hline $\begin{array}{l}\text { Spot } \\
\text { No }\end{array}$ & $\begin{array}{l}\text { Gene } \\
\text { name }\end{array}$ & $\begin{array}{l}\text { Mass } \\
{[\mathrm{kDa}]}\end{array}$ & $\begin{array}{c}\mathrm{p} / \\
{[\mathrm{pH}]}\end{array}$ & $\begin{array}{c}\text { Sequence } \\
\text { length } \\
{[A A]}\end{array}$ & Score & $\begin{array}{c}\text { Sequence } \\
\text { Coverage } \\
{[\%]}\end{array}$ & GI No. & $\begin{array}{c}\text { Accession No } \\
\text { [SwissProtKB/ } \\
\text { Swiss-Prot/ } \\
\text { S.cerevisiae] } \\
\text { (BLAST } \\
\text { Accession No) }\end{array}$ & $\begin{array}{l}\text { Subcellular } \\
\text { localization }\end{array}$ & Description & $\begin{array}{l}\text { Next match, } \\
\text { GI No. } \\
\text { (score) }\end{array}$ \\
\hline 180 & SSA1 & 69.78 & 5 & 642 & 1130 & 36 & gi|144228166 & NP_009396 & Cytoplasm & $\begin{array}{l}\text { ATPase involved in } \\
\text { protein folding and } \\
\text { nuclear localization signal } \\
\text { (NLS)-directed nuclear } \\
\text { transport; member of heat } \\
\text { shock protein } 70 \text { (HSP70) } \\
\text { family; forms a chaperone } \\
\text { complex with Ydj1p. }\end{array}$ & $(-)$ \\
\hline $188^{\mathrm{IB}}$ & SSA1 & 69.78 & 5 & 642 & 60 & 15 & gi|144228166 & NP_009396 & $\begin{array}{l}\text { Cytoplasm } \\
\text { Cell wall }\end{array}$ & $\begin{array}{l}\text { ATPase involved in } \\
\text { protein folding and } \\
\text { nuclear localization signal } \\
\text { (NLS)-directed nuclear } \\
\text { transport; member of heat } \\
\text { shock protein } 70 \text { (HSP70) } \\
\text { family; forms a chaperone } \\
\text { complex with Ydj1p. }\end{array}$ & $(-)$ \\
\hline 179 & SSA2 & 69.59 & 4.95 & 639 & 1100 & 35 & gi|6323004 & NP_013076 & Cytoplasm & $\begin{array}{l}\text { ATP binding protein } \\
\text { involved in protein folding } \\
\text { and vacuolar import of } \\
\text { proteins; member of heat } \\
\text { shock protein } 70 \text { (HSP70) } \\
\text { family; associated with the } \\
\text { chaperonin-containing T- } \\
\text { complex. }\end{array}$ & $\begin{array}{l}\text { Unnamed } \\
\text { protein } \\
\text { product. } \\
\text { gi|3788 (32) }\end{array}$ \\
\hline
\end{tabular}




\begin{tabular}{|c|c|c|c|c|c|c|c|c|c|c|c|}
\hline $\begin{array}{l}\text { Spot } \\
\text { No }\end{array}$ & $\begin{array}{l}\text { Gene } \\
\text { name }\end{array}$ & $\begin{array}{l}\text { Mass } \\
{[k D a]}\end{array}$ & $\begin{array}{c}\mathrm{p} / \\
{[\mathrm{pH}]}\end{array}$ & $\begin{array}{c}\text { Sequence } \\
\text { length } \\
{[A A]}\end{array}$ & Score & $\begin{array}{c}\text { Sequence } \\
\text { Coverage } \\
{[\%]}\end{array}$ & GI No. & $\begin{array}{c}\text { Accession No } \\
\text { [SwissProtKB/ } \\
\text { Swiss-Prot/ } \\
\text { S.cerevisiae] } \\
\text { (BLAST } \\
\text { Accession No) }\end{array}$ & $\begin{array}{l}\text { Subcellular } \\
\text { localization }\end{array}$ & Description & $\begin{array}{l}\text { Next match, } \\
\text { GI No. } \\
\text { (score) }\end{array}$ \\
\hline $116^{D}$ & SSA2 & 69.59 & 4.95 & 639 & 182 & 6 & gi|6323004 & NP_013076 & $\begin{array}{c}\text { Cytoplasm } \\
\text { Cell wall }\end{array}$ & $\begin{array}{l}\text { ATP binding protein } \\
\text { involved in protein folding } \\
\text { and vacuolar import of } \\
\text { proteins; member of heat } \\
\text { shock protein } 70 \text { (HSP70) } \\
\text { family; associated with the } \\
\text { chaperonin-containing T- } \\
\text { complex. }\end{array}$ & $\begin{array}{c}\text { Pau9p, } \\
\text { gi|13129151 } \\
\text { (35) }\end{array}$ \\
\hline 209 & SSB1 & 66.73 & 5.32 & 613 & 173 & 30 & gi|6319972 & NP_010052 & Cytoplasm & $\begin{array}{l}\text { ATPase that is a } \\
\text { ribosome-associated } \\
\text { molecular chaperone, } \\
\text { functions with J-protein } \\
\text { partner Zuo1p; may be } \\
\text { involved in folding of } \\
\text { newly-made polypeptide } \\
\text { chains; member of the } \\
\text { HSP70 family; interacts } \\
\text { with phosphatase subunit } \\
\text { Reg1p }\end{array}$ & $(-)$ \\
\hline 210 & SSB2 & 66.66 & 5.37 & 613 & 775 & 39 & gi|6324120 & NP_014190 & Cytoplasm & $\begin{array}{l}\text { ATPase that is a } \\
\text { ribosome-associated } \\
\text { molecular chaperone, } \\
\text { functions with J-protein } \\
\text { partner Zuo1p; may be } \\
\text { involved in the folding of } \\
\text { newly-synthesized } \\
\text { polypeptide chains; } \\
\text { member of the HSP70 } \\
\text { family; homolog of SSB1. }\end{array}$ & $(-)$ \\
\hline
\end{tabular}




\begin{tabular}{|c|c|c|c|c|c|c|c|c|c|c|c|}
\hline $\begin{array}{l}\text { Spot } \\
\text { No }\end{array}$ & $\begin{array}{l}\text { Gene } \\
\text { name }\end{array}$ & $\begin{array}{l}\text { Mass } \\
{[\mathrm{kDa}]}\end{array}$ & $\begin{array}{c}\mathrm{p} / \\
{[\mathrm{pH}]}\end{array}$ & $\begin{array}{c}\text { Sequence } \\
\text { length } \\
{[A A]}\end{array}$ & Score & $\begin{array}{c}\text { Sequence } \\
\text { Coverage } \\
{[\%]}\end{array}$ & GI No. & $\begin{array}{c}\text { Accession No } \\
\text { [SwissProtKB/ } \\
\text { Swiss-Prot/ } \\
\text { S.cerevisiae] } \\
\text { (BLAST } \\
\text { Accession No) }\end{array}$ & $\begin{array}{l}\text { Subcellular } \\
\text { localization }\end{array}$ & Description & $\begin{array}{l}\text { Next match, } \\
\text { GI No. } \\
\text { (score) }\end{array}$ \\
\hline $211^{D}$ & SSB2 & 66.66 & 5.37 & 613 & 275 & 15 & gi|6324120 & NP_014190 & Cytoplasm & $\begin{array}{l}\text { ATPase that is a } \\
\text { ribosome-associated } \\
\text { molecular chaperone, } \\
\text { functions with J-protein } \\
\text { partner Zuo1p; may be } \\
\text { involved in the folding of } \\
\text { newly-synthesized } \\
\text { polypeptide chains; } \\
\text { member of the HSP70 } \\
\text { family; homolog of SSB1. }\end{array}$ & $(-)$ \\
\hline $189^{A}$ & SSC1 & 70.58 & 5.48 & 654 & 132 & 16 & gi|6322505 & NP_012579 & $\begin{array}{l}\text { Mitochondrion } \\
\text { Nucleus }\end{array}$ & $\begin{array}{l}\text { Hsp70 family ATPase, } \\
\text { constituent of the import } \\
\text { motor component of the } \\
\text { Translocase of the Inner } \\
\text { Mitochondrial membrane } \\
\text { (TIM23 complex); } \\
\text { involved in protein } \\
\text { translocation and folding; } \\
\text { subunit of Scel } \\
\text { endonuclease. }\end{array}$ & $\begin{array}{c}\text { AWRI1631_ } \\
41900, \\
\text { gi|20734693 } \\
4(33)\end{array}$ \\
\hline $191^{\mathrm{B}}$ & SSE1 & 77.6 & 5.12 & 693 & 835 & 36 & gi|6325151 & NP_015219 & Cytoplasm & $\begin{array}{l}\text { ATPase that is a } \\
\text { component of the heat } \\
\text { shock protein Hsp90 } \\
\text { chaperone complex; binds } \\
\text { unfolded proteins; } \\
\text { member of the heat shock } \\
\text { protein } 70 \text { (HSP70) } \\
\text { family. }\end{array}$ & $\begin{array}{c}\text { Pleiotropic } \\
\text { drug } \\
\text { resistance } \\
\text { protein, } \\
\text { gi|15194431 } \\
5(32)\end{array}$ \\
\hline
\end{tabular}




\begin{tabular}{|c|c|c|c|c|c|c|c|c|c|c|c|}
\hline $\begin{array}{l}\text { Spot } \\
\text { No }\end{array}$ & $\begin{array}{l}\text { Gene } \\
\text { name }\end{array}$ & $\begin{array}{l}\text { Mass } \\
{[\mathrm{kDa}]}\end{array}$ & $\begin{array}{c}\mathrm{p} / \\
{[\mathrm{pH}]}\end{array}$ & $\begin{array}{c}\text { Sequence } \\
\text { length } \\
{[\mathrm{AA}]}\end{array}$ & Score & $\begin{array}{c}\text { Sequence } \\
\text { Coverage } \\
{[\%]}\end{array}$ & GI No. & $\begin{array}{c}\text { Accession No } \\
\text { [SwissProtKB/ } \\
\text { Swiss-Prot/ } \\
\text { S.cerevisiae] } \\
\text { (BLAST } \\
\text { Accession No) }\end{array}$ & $\begin{array}{l}\text { Subcellular } \\
\text { localization }\end{array}$ & Description & $\begin{array}{l}\text { Next match, } \\
\text { GI No. } \\
\text { (score) }\end{array}$ \\
\hline $96^{\mathrm{IA}}$ & SUP45 & 48.55 & 5.01 & 432 & 89 & 7 & gi|468605 & CAA51935 & Cytoplasm & $\begin{array}{c}\text { Directs the termination of } \\
\text { nascent peptide synthesis } \\
\text { (translation) in response } \\
\text { to the termination codons } \\
\text { UAA, UAG and UGA }\end{array}$ & $\begin{array}{l}\text { YOR117Wp- } \\
\text { like protein, } \\
\text { gi|20734115 } \\
3(29)\end{array}$ \\
\hline $5^{\mathrm{DB}}$ & $T D H 3$ & 35.83 & 6.46 & 332 & 59 & 7 & gi|6321631 & NP_011708 & Cytoplasm & $\begin{array}{c}\text { Glyceraldehyde-3- } \\
\text { phosphate } \\
\text { dehydrogenase, isozyme } \\
3 \text {, involved in glycolysis } \\
\text { and gluconeogenesis; } \\
\text { tetramer that catalyzes } \\
\text { the reaction of } \\
\text { glyceraldehyde-3- } \\
\text { phosphate to } 1,3 \text { bis- } \\
\text { phosphoglycerate. }\end{array}$ & $(-)$ \\
\hline $181^{\mathrm{D}}$ & TFP1 & 68.02 & 5.17 & 617 & 536 & 33 & gi|3417405 & CAA98761 & $\begin{array}{c}\text { Golgi } \\
\text { Vacuolar } \\
\text { membranes }\end{array}$ & $\begin{array}{l}\text { V/A-type ATP synthase } \\
\text { catalytic subunit A. These } \\
\text { ATPases couple ATP } \\
\text { hydrolysis to the buildup } \\
\text { of a H+ gradient, but V- } \\
\text { type ATPases do not } \\
\text { catalyze the reverse } \\
\text { reaction. }\end{array}$ & $\begin{array}{c}\text { YOL038C-A, } \\
\text { gi|33438876 } \\
\text { (32) }\end{array}$ \\
\hline
\end{tabular}




\begin{tabular}{|c|c|c|c|c|c|c|c|c|c|c|c|}
\hline $\begin{array}{l}\text { Spot } \\
\text { No }\end{array}$ & $\begin{array}{l}\text { Gene } \\
\text { name }\end{array}$ & $\begin{array}{l}\text { Mass } \\
{[\mathrm{kDa}]}\end{array}$ & $\begin{array}{c}\mathrm{p} / \\
{[\mathrm{pH}]}\end{array}$ & $\begin{array}{l}\text { Sequence } \\
\text { length } \\
{[\mathrm{AA}]}\end{array}$ & Score & $\begin{array}{c}\text { Sequence } \\
\text { Coverage } \\
{[\%]}\end{array}$ & GI No. & $\begin{array}{c}\text { Accession No } \\
\text { [SwissProtKB/ } \\
\text { Swiss-Prot/ } \\
\text { S.cerevisiae] } \\
\text { (BLAST } \\
\text { Accession No) }\end{array}$ & $\begin{array}{l}\text { Subcellular } \\
\text { localization }\end{array}$ & Description & $\begin{array}{l}\text { Next match, } \\
\text { GI No. } \\
\text { (score) }\end{array}$ \\
\hline 147 & TIF2 & 44.84 & 5.02 & 395 & 139 & 12 & gi|6322323 & NP_012397 & Cytoplasm & $\begin{array}{l}\text { Translation initiation factor } \\
\text { elF4A, identical to Tif1p; } \\
\text { DEA (D/H)-box RNA } \\
\text { helicase that couples } \\
\text { ATPase activity to RNA } \\
\text { binding and unwinding; } \\
\text { forms a dumbbell } \\
\text { structure of two compact } \\
\text { domains connected by a } \\
\text { linker; interacts with } \\
\text { elF4G. }\end{array}$ & $\begin{array}{c}\text { YML070Wp- } \\
\text { like protein, } \\
\text { gi|20734253 } \\
7(21)\end{array}$ \\
\hline $131^{\prime}$ & TIF6 & 26.66 & 4.54 & 245 & 204 & 31 & gi|6325273 & NP_015341 & $\begin{array}{l}\text { Cytoplasm } \\
\text { Nucleus }> \\
\text { nucleolus }\end{array}$ & $\begin{array}{l}\text { Constituent of } 665 \text { pre- } \\
\text { ribosomal particles, has } \\
\text { similarity to human } \\
\text { translation initiation factor } \\
6 \text { (elF6); may be involved } \\
\text { in the biogenesis and or } \\
\text { stability of } 605 \text { ribosomal } \\
\text { subunits }\end{array}$ & $\begin{array}{l}\text { YCR051W, } \\
\text { gi|6319899 } \\
\text { (56) }\end{array}$ \\
\hline $21^{\prime}$ & $T K L 1$ & 73.8 & 6.48 & 680 & 78 & 8 & gi|3212468 & $\begin{array}{c}\text { 1AY0_A } \\
\text { (NP_015399) }\end{array}$ & Cytoplasm & $\begin{array}{l}\text { Chain A, Identification of } \\
\text { catalytically important } \\
\text { residues in transketolase. }\end{array}$ & $(-)$ \\
\hline
\end{tabular}




\begin{tabular}{|c|c|c|c|c|c|c|c|c|c|c|c|}
\hline $\begin{array}{l}\text { Spot } \\
\text { No }\end{array}$ & $\begin{array}{l}\text { Gene } \\
\text { name }\end{array}$ & $\begin{array}{l}\text { Mass } \\
{[\mathrm{kDa}]}\end{array}$ & $\begin{array}{c}\mathrm{pl} \\
{[\mathrm{pH}]}\end{array}$ & $\begin{array}{c}\text { Sequence } \\
\text { length } \\
{[A A]}\end{array}$ & Score & $\begin{array}{c}\text { Sequence } \\
\text { Coverage } \\
{[\%]}\end{array}$ & GI No. & $\begin{array}{c}\text { Accession No } \\
\text { [SwissProtKB/ } \\
\text { Swiss-Prot/ } \\
\text { S.cerevisiae] } \\
\text { (BLAST } \\
\text { Accession No) }\end{array}$ & $\begin{array}{l}\text { Subcellular } \\
\text { localization }\end{array}$ & Description & $\begin{array}{l}\text { Next match, } \\
\text { GI No. } \\
\text { (score) }\end{array}$ \\
\hline $106^{\mathrm{IA}}$ & TMA19 & 18.78 & 4.41 & 167 & 332 & 32 & gi|6322794 & NP_012867 & $\begin{array}{l}\text { Cytoplasm } \\
\text { Mitochondrion }\end{array}$ & $\begin{array}{l}\text { Protein that associates } \\
\text { with ribosomes; homolog } \\
\text { of translationally } \\
\text { controlled tumor protein; } \\
\text { green fluorescent protein } \\
\text { (GFP)-fusion protein } \\
\text { localizes to the cytoplasm } \\
\text { and relocates to the } \\
\text { mitochondrial outer } \\
\text { surface upon oxidative } \\
\text { stress. }\end{array}$ & $\begin{array}{c}\text { Conserved } \\
\text { protein, } \\
\text { gi|15194110 } \\
5(27)\end{array}$ \\
\hline $45^{\mathrm{IB}}$ & TPI1 & 26.76 & 5.75 & 247 & 181 & 21 & gi|230405 & $\begin{array}{c}\text { 1YPI_A } \\
\text { (NP_010335) }\end{array}$ & Mitochondrion & $\begin{array}{c}\text { Chain A, Triosephosphate } \\
\text { isomerase }\end{array}$ & $\begin{array}{l}\text { N1311, } \\
\text { gi|600049 } \\
(32)\end{array}$ \\
\hline 129 & TPM1 & 23.52 & 4.58 & 199 & 197 & 53 & gi|6324250 & NP_014320 & $\begin{array}{l}\text { Cytoplasm > } \\
\text { cytoskeleton }\end{array}$ & $\begin{array}{l}\text { Major isoform of } \\
\text { tropomyosin; binds to and } \\
\text { stabilizes actin cables and } \\
\text { filaments, which direct } \\
\text { polarized cell growth and } \\
\text { the distribution of several } \\
\text { organelles; acetylated by } \\
\text { the NatB complex and } \\
\text { acetylated form binds } \\
\text { actin most efficiently }\end{array}$ & $\begin{array}{c}\text { YOL024W, } \\
\text { gi|6324549 } \\
(21)\end{array}$ \\
\hline
\end{tabular}




\begin{tabular}{|c|c|c|c|c|c|c|c|c|c|c|c|}
\hline $\begin{array}{l}\text { Spot } \\
\text { No }\end{array}$ & $\begin{array}{l}\text { Gene } \\
\text { name }\end{array}$ & $\begin{array}{l}\text { Mass } \\
{[\mathrm{kDa}]}\end{array}$ & $\begin{array}{c}\mathrm{pl} \\
{[\mathrm{pH}]}\end{array}$ & $\begin{array}{c}\text { Sequence } \\
\text { length } \\
{[A A]}\end{array}$ & Score & $\begin{array}{c}\text { Sequence } \\
\text { Coverage } \\
{[\%]}\end{array}$ & GI No. & $\begin{array}{c}\text { Accession No } \\
\text { [SwissProtKB/ } \\
\text { Swiss-Prot/ } \\
\text { S.cerevisiae] } \\
\text { (BLAST } \\
\text { Accession No) }\end{array}$ & $\begin{array}{l}\text { Subcellular } \\
\text { localization }\end{array}$ & Description & $\begin{array}{l}\text { Next match, } \\
\text { GI No. } \\
\text { (score) }\end{array}$ \\
\hline $115^{l}$ & TSA1 & 21.69 & 5.03 & 196 & 239 & 29 & gi|6323613 & NP_013684 & Cytoplasm & $\begin{array}{l}\text { Thioredoxin peroxidase, } \\
\text { acts as both a ribosome- } \\
\text { associated and free } \\
\text { cytoplasmic antioxidant; } \\
\text { self-associates to form a } \\
\text { high-molecular weight } \\
\text { chaperone complex under } \\
\text { oxidative stress; deletion } \\
\text { results in mutator } \\
\text { phenotype }\end{array}$ & $\begin{array}{l}\text { YML028Wp- } \\
\text { like protein } \\
(144)\end{array}$ \\
\hline $88^{\prime}$ & TUB1 & 50.39 & 4.96 & 447 & 82 & 9 & gi|6323554 & NP_013625 & $\begin{array}{l}\text { Cytoplasm > } \\
\text { cytoskeleton }\end{array}$ & $\begin{array}{l}\text { Alpha-tubulin; associates } \\
\text { with beta-tubulin (Tub2p) } \\
\text { to form tubulin dimer, } \\
\text { which polymerizes to form } \\
\text { microtubules. }\end{array}$ & $\begin{array}{c}\text { Q0130 } \\
\text { gi|2133224 } \\
(26)\end{array}$ \\
\hline 94 & TUB2 & 51.23 & 4.64 & 457 & 319 & 23 & gi|14318481 & NP_116616 & $\begin{array}{l}\text { Cytoplasm > } \\
\text { cytoskeleton }\end{array}$ & $\begin{array}{l}\text { Beta-tubulin; associates } \\
\text { with alpha-tubulin (Tub1p } \\
\text { and Tub3p) to form } \\
\text { tubulin dimer, which } \\
\text { polymerizes to form } \\
\text { microtubules. }\end{array}$ & $\begin{array}{l}\text { YKR101Wp- } \\
\text { like protein, } \\
\text { gi|20734331 } \\
1 \text { (33) }\end{array}$ \\
\hline
\end{tabular}




\begin{tabular}{|c|c|c|c|c|c|c|c|c|c|c|c|}
\hline $\begin{array}{l}\text { Spot } \\
\text { No }\end{array}$ & $\begin{array}{l}\text { Gene } \\
\text { name }\end{array}$ & $\begin{array}{l}\text { Mass } \\
{[\mathrm{kDa}]}\end{array}$ & $\begin{array}{c}\mathrm{p} / \\
{[\mathrm{pH}]}\end{array}$ & $\begin{array}{c}\text { Sequence } \\
\text { length } \\
\text { [AA] }\end{array}$ & Score & $\begin{array}{c}\text { Sequence } \\
\text { Coverage } \\
{[\%]}\end{array}$ & GI No. & $\begin{array}{c}\text { Accession No } \\
\text { [SwissProtKB/ } \\
\text { Swiss-Prot/ } \\
\text { S.cerevisiae] } \\
\text { (BLAST } \\
\text { Accession No) }\end{array}$ & $\begin{array}{l}\text { Subcellular } \\
\text { localization }\end{array}$ & Description & $\begin{array}{c}\text { Next match, } \\
\text { GI No. } \\
\text { (score) }\end{array}$ \\
\hline $154^{\mathrm{D}}$ & VMA2 & 57.77 & 4.95 & 517 & 64 & 10 & gi|6319603 & NP_009685 & $\begin{array}{l}\text { Vacuole } \\
\text { membrane }\end{array}$ & $\begin{array}{l}\text { Subunit B of the eight- } \\
\text { subunit } \mathrm{V} 1 \text { peripheral } \\
\text { membrane domain of the } \\
\text { vacuolar H+-ATPase (V- } \\
\text { ATPase), an electrogenic } \\
\text { proton pump found } \\
\text { throughout the } \\
\text { endomembrane system; } \\
\text { contains nucleotide } \\
\text { binding sites. }\end{array}$ & $\begin{array}{c}\text { Rib3p, } \\
\text { gi|6320695 } \\
\quad(52)\end{array}$ \\
\hline 89 & VMA2 & 57.77 & 4.95 & 517 & 57 & 11 & gi|6319603 & NP_009685 & $\begin{array}{l}\text { Vacuole } \\
\text { membrane }\end{array}$ & $\begin{array}{l}\text { Subunit B of the eight- } \\
\text { subunit } \mathrm{V} 1 \text { peripheral } \\
\text { membrane domain of the } \\
\text { vacuolar H+-ATPase (V- } \\
\text { ATPase), an electrogenic } \\
\text { proton pump found } \\
\text { throughout the } \\
\text { endomembrane system; } \\
\text { contains nucleotide } \\
\text { binding sites. }\end{array}$ & $\begin{array}{l}\text { Unnamed } \\
\text { protein } \\
\text { product, } \\
\text { gi|395245 } \\
(20)\end{array}$ \\
\hline
\end{tabular}




\begin{tabular}{|c|c|c|c|c|c|c|c|c|c|c|c|}
\hline $\begin{array}{l}\text { Spot } \\
\text { No }\end{array}$ & $\begin{array}{l}\text { Gene } \\
\text { name }\end{array}$ & $\begin{array}{l}\text { Mass } \\
{[\mathrm{kDa}]}\end{array}$ & $\begin{array}{c}\mathrm{p} / \\
{[\mathrm{pH}]}\end{array}$ & $\begin{array}{c}\text { Sequence } \\
\text { length } \\
{[\mathrm{AA}]}\end{array}$ & Score & $\begin{array}{c}\text { Sequence } \\
\text { Coverage } \\
{[\%]}\end{array}$ & GI No. & $\begin{array}{c}\text { Accession No } \\
\text { [SwissProtKB/ } \\
\text { Swiss-Prot/ } \\
\text { S.cerevisiae] } \\
\text { (BLAST } \\
\text { Accession No) }\end{array}$ & $\begin{array}{l}\text { Subcellular } \\
\text { localization }\end{array}$ & Description & $\begin{array}{l}\text { Next match, } \\
\text { GI No. } \\
\text { (score) }\end{array}$ \\
\hline $124^{\prime}$ & VMA4 & 26.45 & 5.33 & 233 & 253 & 48 & gi|6324907 & NP_014977 & $\begin{array}{l}\text { Vacuole } \\
\text { membrane }\end{array}$ & $\begin{array}{l}\text { Subunit } \mathrm{E} \text { of the eight- } \\
\text { subunit } \mathrm{V} 1 \text { peripheral } \\
\text { membrane domain of the } \\
\text { vacuolar } \mathrm{H}+-\mathrm{ATP} \text { Tase }(\mathrm{V}- \\
\text { ATPase), an electrogenic } \\
\text { proton pump found } \\
\text { throughout the } \\
\text { endomembrane system; } \\
\text { required for the } \mathrm{V} 1 \\
\text { domain to assemble onto } \\
\text { the vacuolar membrane }\end{array}$ & $\begin{array}{l}\text { YOR332Wp- } \\
\text { like protein } \\
\text { (133) }\end{array}$ \\
\hline 135 & VMA6 & 40.1 & 4.48 & 345 & 81 & 12 & gi|6323480 & NP_013552 & $\begin{array}{l}\text { Vacuole } \\
\text { membrane }\end{array}$ & $\begin{array}{l}\text { Subunit d of the five- } \\
\text { subunit V0 integral } \\
\text { membrane domain of } \\
\text { vacuolar H+-ATPase (V- } \\
\text { ATPase), an electrogenic } \\
\text { proton pump found in the } \\
\text { endomembrane system; } \\
\text { stabilizes VO subunits; } \\
\text { required for V1 domain } \\
\text { assembly on the vacuolar } \\
\text { membrane. }\end{array}$ & $\begin{array}{c}\text { Erp6p, } \\
\text { gi|6321436 } \\
(24)\end{array}$ \\
\hline
\end{tabular}




\begin{tabular}{|c|c|c|c|c|c|c|c|c|c|c|c|}
\hline $\begin{array}{l}\text { Spot } \\
\text { No }\end{array}$ & $\begin{array}{l}\text { Gene } \\
\text { name }\end{array}$ & $\begin{array}{l}\text { Mass } \\
{[\mathrm{kDa}]}\end{array}$ & $\begin{array}{c}\mathrm{pl} \\
{[\mathrm{pH}]}\end{array}$ & $\begin{array}{c}\text { Sequence } \\
\text { length } \\
{[A A]}\end{array}$ & Score & $\begin{array}{c}\text { Sequence } \\
\text { Coverage } \\
{[\%]}\end{array}$ & GI No. & $\begin{array}{c}\text { Accession No } \\
\text { [SwissProtKB/ } \\
\text { Swiss-Prot/ } \\
\text { S.cerevisiae] } \\
\text { (BLAST } \\
\text { Accession No) }\end{array}$ & $\begin{array}{l}\text { Subcellular } \\
\text { localization }\end{array}$ & Description & $\begin{array}{l}\text { Next match, } \\
\text { GI No. } \\
\text { (score) }\end{array}$ \\
\hline $101^{D}$ & VMA7 & 13.45 & 4.98 & 118 & 96 & 30 & gi|6321457 & NP_011534 & $\begin{array}{l}\text { Vacuole } \\
\text { membrane }\end{array}$ & $\begin{array}{l}\text { Subunit } \mathrm{F} \text { of the eight- } \\
\text { subunit } \mathrm{V} 1 \text { peripheral } \\
\text { membrane domain of } \\
\text { vacuolar } \mathrm{H}+-\mathrm{ATPase}(\mathrm{V}- \\
\mathrm{ATPase} \text { ), an electrogenic } \\
\text { proton pump found } \\
\text { throughout the } \\
\text { endomembrane system; } \\
\text { required for the } \mathrm{V} 1 \\
\text { domain to assemble onto } \\
\text { the vacuolar membrane. }\end{array}$ & $\begin{array}{c}\text { Tex1p, } \\
\text { gi|6324076 } \\
(32)\end{array}$ \\
\hline $186^{\mathrm{IB}}$ & WTM1 & 48.46 & 5.18 & 437 & 129 & 10 & gi|6324804 & NP_014873 & $\begin{array}{l}\text { Cytoplasm } \\
\text { Nucleus }\end{array}$ & $\begin{array}{l}\text { Transcriptional modulator } \\
\text { involved in regulation of } \\
\text { meiosis, silencing, and } \\
\text { expression of RNR genes; } \\
\text { required for nuclear } \\
\text { localization of the } \\
\text { ribonucleotide reductase } \\
\text { small subunit Rnr2p and } \\
\text { Rnr4p; contains WD } \\
\text { repeats. }\end{array}$ & $\begin{array}{l}12 \mathrm{kDa} \text { heat } \\
\text { shock } \\
\text { protein, } \\
\text { gi| } 18479209 \\
(30)\end{array}$ \\
\hline $20^{\mathrm{B}}$ & $\begin{array}{c}\text { YDR341 } \\
C\end{array}$ & 69.64 & 6.29 & 607 & 84 & 15 & gi|190404719 & $\begin{array}{c}\text { EDV07986 } \\
\text { (NP_010628) }\end{array}$ & Cytoplasm & Arginyl-tRNA synthetase. & $\begin{array}{c}\text { Acp1p, } \\
\text { gi|6322656 } \\
(27)\end{array}$ \\
\hline
\end{tabular}




\begin{tabular}{|c|c|c|c|c|c|c|c|c|c|c|c|}
\hline $\begin{array}{l}\text { Spot } \\
\text { No }\end{array}$ & $\begin{array}{l}\text { Gene } \\
\text { name }\end{array}$ & $\begin{array}{l}\text { Mass } \\
{[\mathrm{kDa}]}\end{array}$ & $\begin{array}{c}\mathrm{pl} \\
{[\mathrm{pH}]}\end{array}$ & $\begin{array}{c}\text { Sequence } \\
\text { length } \\
{[\mathrm{AA}]}\end{array}$ & Score & $\begin{array}{c}\text { Sequence } \\
\text { Coverage } \\
{[\%]}\end{array}$ & GI No. & $\begin{array}{c}\text { Accession No } \\
\text { [SwissProtKB/ } \\
\text { Swiss-Prot/ } \\
\text { S.cerevisiae] } \\
\text { (BLAST } \\
\text { Accession No) }\end{array}$ & $\begin{array}{l}\text { Subcellular } \\
\text { localization }\end{array}$ & Description & $\begin{array}{l}\text { Next match, } \\
\text { GI No. } \\
\text { (score) }\end{array}$ \\
\hline $193^{B}$ & $\begin{array}{c}\text { YHRO20 } \\
W\end{array}$ & 77.85 & 6.02 & 688 & 131 & 13 & gi|6321808 & NP_011884 & Cytoplasm & $\begin{array}{l}\text { Hypothetical protein that } \\
\text { may interact with } \\
\text { ribosomes, based on co- } \\
\text { purification experiments; } \\
\text { has similarity to proline- } \\
\text { tRNA ligase; YHR020W is } \\
\text { an essential gene }\end{array}$ & $\begin{array}{c}\text { Mas2p, } \\
\text { gi|6321813 } \\
(27)\end{array}$ \\
\hline $99^{\prime}$ & ZEO1 & 12.58 & 5.43 & 113 & 443 & 60 & gi|6324463 & NP_014532 & $\begin{array}{l}\text { Plasma } \\
\text { membrane }\end{array}$ & $\begin{array}{l}\text { Interacts with Mid2p; } \\
\text { regulates the cell integrity } \\
\text { pathway mediated by } \\
\text { Pkc1p and SIt } 2 p ; \text { the } \\
\text { authentic protein is } \\
\text { detected in a } \\
\text { phosphorylated state in } \\
\text { highly purified } \\
\text { mitochondria. }\end{array}$ & $\begin{array}{c}\text { Cct8p, } \\
\text { gi|6322452 } \\
(24)\end{array}$ \\
\hline
\end{tabular}




\subsection{2. $2 \mathrm{D}$ analysis of $\mathrm{pI}$ 6-11 proteins}

The image of proteins separated by 2DE using pH 6-11 IEF is shown in Figure 14. The Coomassie stained gel showed 152 visible proteins. The total number of proteins identified by PMF was 70 at the $5 \%$ level of significance. Table 6 shows pH 6-11 proteins identified by MALDI MS/MS. Thirty-three identifications corresponded to unique protein matches. The other 37 proteins represented multiple spots of proteins or protein isoforms. Proteins with multiple spots included Cdc19, Gpm1, Rps5, Tdh3 and Tef2. Identified isoforms included Atp1, Atp3, Cdc12, Cdc19, Imd2, Imd4, Rpl11A, Rpl12B, Rpl13B, Rpl13A, Rps15, Rps19B, Rps20, Rps22A, Rps27A, Rps3, Rps4B, Rps5, Rps7A, Shm1, Shm2, Tdh1, Tdh3, Tef2 and Tef4. The next protein match found $30.2 \%$ of the proteins that were next in line for a match were significant at the $5 \%$ level (score value $\geq 56$ ). Six glycolytic proteins (Cdc19, Eno2, Gpm1, Pgk1, Tdh1 and Tdh3) were found. The abbreviation for pyruvate kinase is Cdc19. 


\section{6}

pl

11

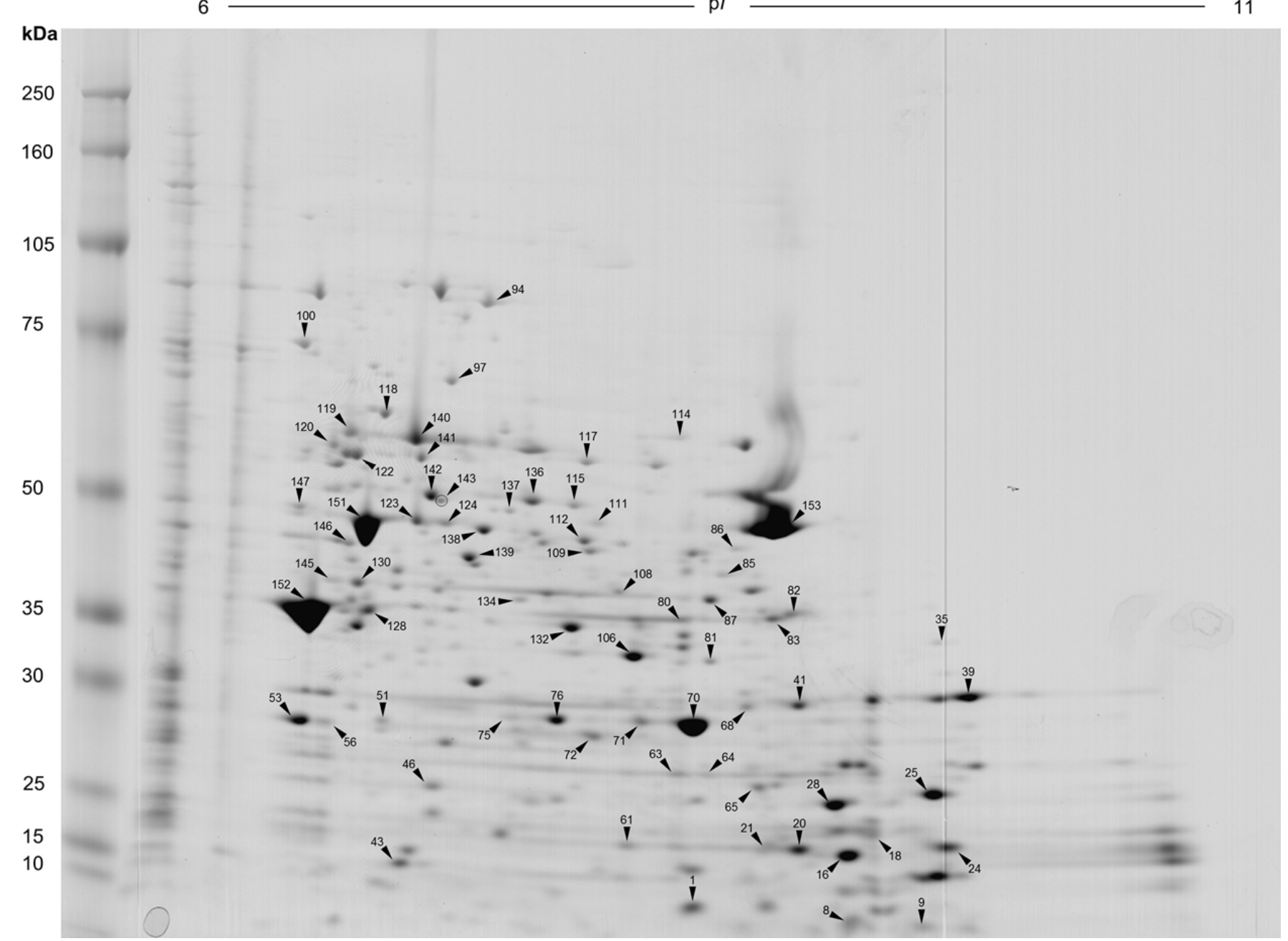

Figure 14 - The 2DE image representing the protein $(100 \mu \mathrm{g})$ profile of BY4741 separated on a pH 6-11 gradient. Proteins were stained with Coomassie. Protein identification was done by MALDI mass spectrometry and significantly identified proteins are marked with an $\infty$ arrow (Table 6). The ladder used for molecular weight reference was Rainbow 851. 
Table 6 - A summary of identified BY4741 proteins separated on a 6-11 pH gradient. Proteins were separated by 2DE and identified by MALDI mass spectrometry. Proteins (score $\geq 56, p \leq 0.05)$ were alphabetized by gene name. The score and sequence coverage $(\%)$ values are representative of the significance of the match generated by the MASCOT search. The calculated mass, pI, GI, accession number and description of the protein are gathered from the NCBI protein website. The subcellular localization of the protein was found using Uniprot. The next matched protein was the next non-homologous protein matched. The spot position was cross checked with the calculated $\mathrm{pI}$ and $\mathrm{Mr}$ values. Alterations in protein positioning resulted in the labeling of A: acidic shift or B: basic shift in pI; I: increase or D: decrease in Mr.

\begin{tabular}{|c|c|c|c|c|c|c|c|c|c|c|c|}
\hline $\begin{array}{l}\text { Spot } \\
\text { No }\end{array}$ & $\begin{array}{l}\text { Gene } \\
\text { name }\end{array}$ & $\begin{array}{l}\text { Mass } \\
{[\mathrm{kDa}]}\end{array}$ & $\mathrm{p} /[\mathrm{pH}]$ & $\begin{array}{c}\text { Sequence } \\
\text { length } \\
{[A A]}\end{array}$ & Score & $\begin{array}{c}\text { Sequence } \\
\text { Coverage } \\
{[\%]}\end{array}$ & GI No & $\begin{array}{c}\text { Accession No } \\
\text { [SwissProtKB/ } \\
\text { Swiss-Prot/ } \\
\text { S.cerevisiae] } \\
\text { (BLAST } \\
\text { Accession No) }\end{array}$ & $\begin{array}{l}\text { Subcellular } \\
\text { localization }\end{array}$ & Description & $\begin{array}{c}\text { Next } \\
\text { match, GI } \\
\text { no (score) }\end{array}$ \\
\hline $109^{D A}$ & AAT2 & 47.99 & 8.89 & 432 & 140 & 17 & gi|1360338 & CAA97550 & $\begin{array}{l}\text { Cytoplasm } \\
\text { Peroxisome }\end{array}$ & $\begin{array}{l}\text { Aspartate } \\
\text { aminotransferase family. } \\
\text { This family belongs to } \\
\text { pyridoxal phosphate } \\
\text { (PLP)-dependent } \\
\text { aspartate } \\
\text { aminotransferase } \\
\text { superfamily (fold I). } \\
\text { Pyridoxal phosphate } \\
\text { combines with an alpha- } \\
\text { amino acid to form a } \\
\text { compound called a Schiff } \\
\text { base or aldimine. }\end{array}$ & $\begin{array}{c}\text { Q0130, } \\
\text { gi|213322 } \\
4(26)\end{array}$ \\
\hline $138^{\prime}$ & $A R C 1$ & 42.44 & 7.7 & 375 & 410 & 23 & gi|1002712 & $\begin{array}{c}\text { AAC49072 } \\
\text { (NP_011410) }\end{array}$ & Cytoplasm & $\begin{array}{l}\text { G4p1 (GU4 nucleic } \\
\text { binding-protein 1). }\end{array}$ & $\begin{array}{c}\text { High-copy } \\
\text { hsp90 } \\
\text { suppress } \\
\text { or, } \\
\text { gi|151944 } \\
268(38)\end{array}$ \\
\hline
\end{tabular}




\begin{tabular}{|c|c|c|c|c|c|c|c|c|c|c|c|}
\hline $\begin{array}{l}\text { Spot } \\
\text { No }\end{array}$ & $\begin{array}{l}\text { Gene } \\
\text { name }\end{array}$ & $\begin{array}{l}\text { Mass } \\
{[\mathrm{kDa}]}\end{array}$ & $\mathrm{p} /[\mathrm{pH}]$ & $\begin{array}{l}\text { Sequence } \\
\text { length } \\
{[\mathrm{AA}]}\end{array}$ & Score & $\begin{array}{c}\text { Sequence } \\
\text { Coverage } \\
{[\%]}\end{array}$ & GI No & $\begin{array}{c}\text { Accession No } \\
\text { [SwissProtKB/ } \\
\text { Swiss-Prot/ } \\
\text { S.cerevisiae] } \\
\text { (BLAST } \\
\text { Accession No) }\end{array}$ & $\begin{array}{l}\text { Subcellular } \\
\text { localization }\end{array}$ & Description & $\begin{array}{c}\text { Next } \\
\text { match, GI } \\
\text { no (score) }\end{array}$ \\
\hline 122 & ATP1 & 54.96 & 6.73 & 510 & 499 & 33 & $\begin{array}{c}\text { gi|} 11938990 \\
4\end{array}$ & $\begin{array}{c}\text { 2HLD_A } \\
\left(\mathrm{NP} \_009453\right)\end{array}$ & $\begin{array}{l}\text { Mitochondrion } \\
\text { inner membrane }\end{array}$ & $\begin{array}{c}\text { Chain A, Mitochondrial } \\
\text { F1-Atpase. }\end{array}$ & $\begin{array}{l}\text { Imd3p, } \\
\text { gi|632346 } \\
4(495)\end{array}$ \\
\hline $81^{A}$ & ATP3 & 30.65 & 9.06 & 278 & 88 & 23 & $\begin{array}{c}\text { gi|} 11938991 \\
0\end{array}$ & $\begin{array}{c}\text { 2HLD_G } \\
\left(\mathrm{NP} \_009595\right)\end{array}$ & $\begin{array}{l}\text { Mitochondrion } \\
\text { inner membrane }\end{array}$ & $\begin{array}{c}\text { Chain G, Mitochondrial } \\
\text { F1-Atpase. }\end{array}$ & $\begin{array}{c}\text { YBR039 } \\
\text { Wp-like } \\
\text { protein, } \\
\text { gi|207347 } \\
765 \text { (49) }\end{array}$ \\
\hline $108^{\mathrm{DA}}$ & $B A T 1$ & 43.79 & 9.01 & 393 & 77 & 23 & gi|6322002 & NP_012078 & $\begin{array}{l}\text { Mitochondrion } \\
\text { matrix }\end{array}$ & $\begin{array}{l}\text { Mitochondrial branched- } \\
\text { chain amino acid } \\
\text { aminotransferase, } \\
\text { homolog of murine } \\
\text { ECA39; highly expressed } \\
\text { during logarithmic phase } \\
\text { and repressed during } \\
\text { stationary phase. }\end{array}$ & $(-)$ \\
\hline $111^{\mathrm{IA}}$ & CAM1 & 24.69 & 9.14 & 219 & 102 & 23 & gi|28374020 & $\begin{array}{c}\text { 1NHY_A } \\
\left(\mathrm{NP} \_015277\right)\end{array}$ & $\begin{array}{l}\text { Cytoplasm } \\
\text { Nucleus }\end{array}$ & $\begin{array}{c}\text { Chain A, GST-like domain } \\
\text { of elongation factor 1- } \\
\text { gamma. }\end{array}$ & $\begin{array}{l}\text { Spc42p, } \\
\text { gi|632280 } \\
9(29)\end{array}$ \\
\hline
\end{tabular}




\begin{tabular}{|c|c|c|c|c|c|c|c|c|c|c|c|}
\hline $\begin{array}{l}\text { Spot } \\
\text { No }\end{array}$ & $\begin{array}{l}\text { Gene } \\
\text { name }\end{array}$ & $\begin{array}{l}\text { Mass } \\
{[\mathrm{kDa}]}\end{array}$ & $\mathrm{p} /[\mathrm{pH}]$ & $\begin{array}{c}\text { Sequence } \\
\text { length } \\
{[\mathrm{AA}]}\end{array}$ & Score & $\begin{array}{c}\text { Sequence } \\
\text { Coverage } \\
{[\%]}\end{array}$ & GI No & $\begin{array}{c}\text { Accession No } \\
\text { [SwissProtKB/ } \\
\text { Swiss-Prot/ } \\
\text { S.cerevisiae] } \\
\text { (BLAST } \\
\text { Accession No) }\end{array}$ & $\begin{array}{l}\text { Subcellular } \\
\text { localization }\end{array}$ & Description & $\begin{array}{c}\text { Next } \\
\text { match, GI } \\
\text { no (score) }\end{array}$ \\
\hline $137^{\prime}$ & CDC12 & 46.75 & 7.77 & 407 & 121 & 27 & gil6321899 & NP_011975 & $\begin{array}{c}\text { Membrane } \\
\text { Peripheral } \\
\text { membrane bud } \\
\text { neck }\end{array}$ & $\begin{array}{l}\text { Component of the septin } \\
\text { ring of the mother-bud } \\
\text { neck that is required for } \\
\text { cytokinesis; septins recruit } \\
\text { proteins to the neck and } \\
\text { can act as a barrier to } \\
\text { diffusion at the } \\
\text { membrane, and they } \\
\text { comprise the } 10 \mathrm{~nm} \\
\text { filaments seen with EM. }\end{array}$ & $\begin{array}{l}\text { Silent } \\
\text { mating } \\
\text { loci } \\
\text { repressor, } \\
\text { gi|151941 } \\
641(32)\end{array}$ \\
\hline $140^{\mathrm{A}}$ & CDC19 & 54.9 & 7.56 & 500 & 442 & 34 & gi|6319279 & NP_009362 & Cytoplasm & $\begin{array}{l}\text { Pyruvate kinase, converts } \\
\text { phosphoenolpyruvate to } \\
\text { pyruvate in glycolysis, the } \\
\text { input for aerobic (TCA } \\
\text { cycle) or anaerobic } \\
\text { (glucose fermentation) } \\
\text { respiration. }\end{array}$ & $\begin{array}{c}\text { Threonine } \\
\text { deaminas } \\
e, \\
\text { gil190405 } \\
649 \text { (39) }\end{array}$ \\
\hline $119^{\mathrm{IA}}$ & CDC19 & 54.9 & 7.56 & 500 & 362 & 31 & gi|6319279 & NP_009362 & Cytoplasm & $\begin{array}{l}\text { Pyruvate kinase, functions } \\
\text { as a homotetramer in } \\
\text { glycolysis to convert } \\
\text { phosphoenolpyruvate to } \\
\text { pyruvate, the input for } \\
\text { aerobic (TCA cycle) or } \\
\text { anaerobic (glucose } \\
\text { fermentation) respiration. }\end{array}$ & $\begin{array}{c}\text { YBR069C } \\
\text { p-like } \\
\text { protein, } \\
\text { gi|207347 } \\
739(34)\end{array}$ \\
\hline
\end{tabular}




\begin{tabular}{|c|c|c|c|c|c|c|c|c|c|c|c|}
\hline $\begin{array}{l}\text { Spot } \\
\text { No }\end{array}$ & $\begin{array}{l}\text { Gene } \\
\text { name }\end{array}$ & $\begin{array}{l}\text { Mass } \\
{[\mathrm{kDa}]}\end{array}$ & $\mathrm{p} /[\mathrm{pH}]$ & $\begin{array}{c}\text { Sequence } \\
\text { length } \\
{[A A]}\end{array}$ & Score & $\begin{array}{c}\text { Sequence } \\
\text { Coverage } \\
{[\%]}\end{array}$ & GI No & $\begin{array}{c}\text { Accession No } \\
\text { [SwissProtKB/ } \\
\text { Swiss-Prot/ } \\
\text { S.cerevisiae] } \\
\text { (BLAST } \\
\text { Accession No) }\end{array}$ & $\begin{array}{l}\text { Subcellular } \\
\text { localization }\end{array}$ & Description & $\begin{array}{c}\text { Next } \\
\text { match, GI } \\
\text { no (score) }\end{array}$ \\
\hline $120^{A}$ & CDC19 & 54.9 & 7.56 & 500 & 310 & 24 & gi|6319279 & NP_009362 & Cytoplasm & $\begin{array}{l}\text { Pyruvate kinase, functions } \\
\text { as a homotetramer in } \\
\text { glycolysis to convert } \\
\text { phosphoenolpyruvate to } \\
\text { pyruvate, the input for } \\
\text { aerobic (TCA cycle) or } \\
\text { anaerobic (glucose } \\
\text { fermentation) respiration. }\end{array}$ & $\begin{array}{c}\text { ATPase } 1 \\
\text { alpha } \\
\text { subunit, } \\
\text { gi|171116 } \\
\text { (34) }\end{array}$ \\
\hline $130^{\mathrm{DA}}$ & CDC19 & 54.96 & 8 & 499 & 259 & 21 & gi|4180 & CAA24631 & Cytoplasm & $\begin{array}{l}\text { Pyruvate kinase, functions } \\
\text { as a homotetramer in } \\
\text { glycolysis to convert } \\
\text { phosphoenolpyruvate to } \\
\text { pyruvate, the input for } \\
\text { aerobic (TCA cycle) or } \\
\text { anaerobic (glucose } \\
\text { fermentation) respiration. }\end{array}$ & $\begin{array}{l}\text { Branched } \\
\text {-chain } \\
\text { amino } \\
\text { acid } \\
\text { transamin } \\
\text { ase, } \\
\text { gi|151945 } \\
213(176)\end{array}$ \\
\hline $72^{\mathrm{D}}$ & CDC19 & 54.96 & 8 & 499 & 156 & 14 & gi|4180 & CAA24631 & Cytoplasm & $\begin{array}{l}\text { Pyruvate kinase, functions } \\
\text { as a homotetramer in } \\
\text { glycolysis to convert } \\
\text { phosphoenolpyruvate to } \\
\text { pyruvate, the input for } \\
\text { aerobic (TCA cycle) or } \\
\text { anaerobic (glucose } \\
\text { fermentation) respiration. }\end{array}$ & $\begin{array}{c}\text { Rps5p, } \\
\text { gi|632258 } \\
3(68)\end{array}$ \\
\hline
\end{tabular}




\begin{tabular}{|c|c|c|c|c|c|c|c|c|c|c|c|}
\hline $\begin{array}{l}\text { Spot } \\
\text { No }\end{array}$ & $\begin{array}{l}\text { Gene } \\
\text { name }\end{array}$ & $\begin{array}{l}\text { Mass } \\
{[\mathrm{kDa}]}\end{array}$ & $\mathrm{p} /[\mathrm{pH}]$ & $\begin{array}{c}\text { Sequence } \\
\text { length } \\
{[\mathrm{AA}]}\end{array}$ & Score & $\begin{array}{c}\text { Sequence } \\
\text { Coverage } \\
{[\%]}\end{array}$ & GI No & $\begin{array}{c}\text { Accession No } \\
\text { [SwissProtKB/ } \\
\text { Swiss-Prot/ } \\
\text { S.cerevisiae] } \\
\text { (BLAST } \\
\text { Accession No) }\end{array}$ & $\begin{array}{l}\text { Subcellular } \\
\text { localization }\end{array}$ & Description & $\begin{array}{c}\text { Next } \\
\text { match, GI } \\
\text { no (score) }\end{array}$ \\
\hline $46^{\mathrm{DA}}$ & $C D C 19$ & 54.96 & 8 & 499 & 62 & 13 & gi|4180 & CAA24631 & Cytoplasm & $\begin{array}{l}\text { Pyruvate kinase, functions } \\
\text { as a homotetramer in } \\
\text { glycolysis to convert } \\
\text { phosphoenolpyruvate to } \\
\text { pyruvate, the input for } \\
\text { aerobic (TCA cycle) or } \\
\text { anaerobic (glucose } \\
\text { fermentation) respiration. }\end{array}$ & $\begin{array}{c}\text { Lsp1p, } \\
\text { gi|632525 } \\
3(20)\end{array}$ \\
\hline 114 & $D B P 2$ & 61.23 & 8.8 & 546 & 90 & 17 & $\begin{array}{c}\text { gi|16038061 } \\
1\end{array}$ & $\begin{array}{c}\text { A6ZRX0 } \\
\text { (NP_014287.3) }\end{array}$ & $\begin{array}{l}\text { Cytoplasm } \\
\text { Nucleus }\end{array}$ & $\begin{array}{l}\text { ATP-dependent RNA } \\
\text { helicase involved } \\
\text { nonsense-mediated } \\
\text { mRNA decay and } \\
\text { ribosome biogenesis } \\
\text { through rRNA processing. }\end{array}$ & $\begin{array}{c}\text { Cbr1p, } \\
\text { gi|865589 } \\
08(26)\end{array}$ \\
\hline $97^{\mathrm{A}}$ & $D E D 1$ & 65.73 & 8.18 & 604 & 129 & 25 & gi|227524 & $\begin{array}{c}1705300 A \\
\left(N P \_014847\right)\end{array}$ & Cytoplasm & $\begin{array}{l}\text { ATP dependent RNA } \\
\text { helicase. }\end{array}$ & $\begin{array}{l}\text { Chain A, } \\
\text { Scpex13p } \\
\text { Sh3 } \\
\text { domain, } \\
\text { gi|289489 } \\
68(25)\end{array}$ \\
\hline
\end{tabular}




\begin{tabular}{|c|c|c|c|c|c|c|c|c|c|c|c|}
\hline $\begin{array}{l}\text { Spot } \\
\text { No }\end{array}$ & $\begin{array}{l}\text { Gene } \\
\text { name }\end{array}$ & $\begin{array}{l}\text { Mass } \\
{[\mathrm{kDa}]}\end{array}$ & $\mathrm{p} /[\mathrm{pH}]$ & $\begin{array}{c}\text { Sequence } \\
\text { length } \\
{[A A]}\end{array}$ & Score & $\begin{array}{c}\text { Sequence } \\
\text { Coverage } \\
{[\%]}\end{array}$ & GI No & $\begin{array}{c}\text { Accession No } \\
\text { [SwissProtKB/ } \\
\text { Swiss-Prot/ } \\
\text { S.cerevisiae] } \\
\text { (BLAST } \\
\text { Accession No) }\end{array}$ & $\begin{array}{l}\text { Subcellular } \\
\text { localization }\end{array}$ & Description & $\begin{array}{c}\text { Next } \\
\text { match, GI } \\
\text { no (score) }\end{array}$ \\
\hline $143^{\mathrm{DA}}$ & EHT1 & 51.5 & 7.64 & 451 & 174 & 23 & gi|6319655 & NP_009736 & $\begin{array}{l}\text { Lipid Particle } \\
\text { Mitochondrion } \\
\text { outer membrane }\end{array}$ & $\begin{array}{l}\text { Acyl-coenzymeA: ethanol } \\
\text { O-acyltransferase that } \\
\text { plays a minor role in } \\
\text { medium-chain fatty acid } \\
\text { ethyl ester biosynthesis; } \\
\text { possesses short-chain } \\
\text { esterase activity; localizes } \\
\text { to lipid particles and the } \\
\text { mitochondrial outer } \\
\text { membrane. }\end{array}$ & $\begin{array}{c}\text { Shm2p, } \\
\text { gi|632308 } \\
7(132)\end{array}$ \\
\hline $8^{\mathrm{DB}}$ & ENO2 & 46.94 & 5.67 & 437 & 295 & 33 & gi|6321968 & NP_012044 & Cytoplasm & $\begin{array}{c}\text { Enolase II, a } \\
\text { phosphopyruvate } \\
\text { hydratase that catalyzes } \\
\text { the conversion of 2- } \\
\text { phosphoglycerate to } \\
\text { phosphoenolpyruvate } \\
\text { during glycolysis and the } \\
\text { reverse reaction during } \\
\text { gluconeogenesis; } \\
\text { expression is induced in } \\
\text { response to glucose. }\end{array}$ & $\begin{array}{c}\text { Chain A, } \\
\text { Mata1MA } \\
\text { TALPHA2 } \\
-3 a \\
\text { heterodim } \\
\text { er bound } \\
\text { to DNA } \\
\text { complex, } \\
\text { gi|214660 } \\
66(26)\end{array}$ \\
\hline
\end{tabular}




\begin{tabular}{|c|c|c|c|c|c|c|c|c|c|c|c|}
\hline $\begin{array}{l}\text { Spot } \\
\text { No }\end{array}$ & $\begin{array}{l}\text { Gene } \\
\text { name }\end{array}$ & $\begin{array}{l}\text { Mass } \\
{[\mathrm{kDa}]}\end{array}$ & $\mathrm{p} /[\mathrm{pH}]$ & $\begin{array}{l}\text { Sequence } \\
\text { length } \\
{[A A]}\end{array}$ & Score & $\begin{array}{c}\text { Sequence } \\
\text { Coverage } \\
{[\%]}\end{array}$ & GI No & $\begin{array}{c}\text { Accession No } \\
\text { [SwissProtKB/ } \\
\text { Swiss-Prot/ } \\
\text { S.cerevisiae] } \\
\text { (BLAST } \\
\text { Accession No) }\end{array}$ & $\begin{array}{l}\text { Subcellular } \\
\text { localization }\end{array}$ & Description & $\begin{array}{c}\text { Next } \\
\text { match, GI } \\
\text { no (score) }\end{array}$ \\
\hline $146^{A}$ & ERG10 & 42.04 & 7.01 & 398 & 111 & 10 & gil6325229 & NP_015297 & Cytoplasm & $\begin{array}{c}\text { Acetyl-CoA C- } \\
\text { acetyltransferase } \\
\text { (acetoacetyl-CoA } \\
\text { thiolase), Cytoplasmic } \\
\text { enzyme that transfers an } \\
\text { acetyl group from one } \\
\text { acetyl-CoA molecule to } \\
\text { another, forming } \\
\text { acetoacetyl-CoA; involved } \\
\text { in the first step in } \\
\text { mevalonate biosynthesis. }\end{array}$ & $\begin{array}{c}\text { Chain C, } \\
\text { Ribosoma } \\
\text { I 80s- } \\
\text { Eef2- } \\
\text { Sordarin } \\
\text { complex, } \\
\text { gi|492588 } \\
41(49)\end{array}$ \\
\hline $76^{1 A}$ & GPM1 & 26.68 & 8.27 & 237 & 269 & 48 & $\begin{array}{c}\text { gi|15788446 } \\
6\end{array}$ & $\begin{array}{c}\text { 5PGM_E } \\
\left(\mathrm{NP} \_012770\right)\end{array}$ & $\begin{array}{l}\text { Cytoplasm } \\
\text { Mitochondrion }\end{array}$ & $\begin{array}{l}\text { Chain E, } \\
\text { Phosphoglycerate } \\
\text { mutase. }\end{array}$ & $\begin{array}{c}\text { Fab1p, } \\
\text { gi|143185 } \\
41(29)\end{array}$ \\
\hline $70^{\prime}$ & GPM1 & 26.68 & 8.27 & 237 & 247 & 47 & $\begin{array}{c}\text { gi|15788446 } \\
6\end{array}$ & $\begin{array}{c}\text { 5PGM_E } \\
\left(\mathrm{NP} \_012770\right)\end{array}$ & $\begin{array}{l}\text { Cytoplasm } \\
\text { Mitochondrion }\end{array}$ & $\begin{array}{c}\text { Chain E, } \\
\text { Phosphoglycerate } \\
\text { mutase. }\end{array}$ & $\begin{array}{c}\text { Pau9p, } \\
\text { gi|131291 } \\
51(36)\end{array}$ \\
\hline $65^{\mathrm{DB}}$ & GPM1 & 26.68 & 8.27 & 237 & 122 & 35 & $\begin{array}{c}\text { gi|15788446 } \\
6\end{array}$ & $\begin{array}{c}\text { 5PGM_E } \\
\text { (NP_012770) }\end{array}$ & $\begin{array}{l}\text { Cytoplasm } \\
\text { Mitochondrion }\end{array}$ & $\begin{array}{l}\text { Chain E, } \\
\text { Phosphoglycerate } \\
\text { mutase. }\end{array}$ & $\begin{array}{c}\text { Chain B, } \\
\text { Sec23- } \\
\text { Sar1 } \\
\text { complexe } \\
\text { d with the } \\
\text { active } \\
\text { fragment } \\
\text { of Sec31, } \\
\text { gi|165761 } \\
045(30)\end{array}$ \\
\hline
\end{tabular}




\begin{tabular}{|c|c|c|c|c|c|c|c|c|c|c|c|}
\hline $\begin{array}{l}\text { Spot } \\
\text { No }\end{array}$ & $\begin{array}{l}\text { Gene } \\
\text { name }\end{array}$ & $\begin{array}{l}\text { Mass } \\
{[\mathrm{kDa}]}\end{array}$ & $\mathrm{p} /[\mathrm{pH}]$ & $\begin{array}{c}\text { Sequence } \\
\text { length } \\
{[A A]}\end{array}$ & Score & $\begin{array}{c}\text { Sequence } \\
\text { Coverage } \\
{[\%]}\end{array}$ & GI No & $\begin{array}{c}\text { Accession No } \\
\text { [SwissProtKB/ } \\
\text { Swiss-Prot/ } \\
\text { S.cerevisiae] } \\
\text { (BLAST } \\
\text { Accession No) }\end{array}$ & $\begin{array}{l}\text { Subcellular } \\
\text { localization }\end{array}$ & Description & $\begin{array}{c}\text { Next } \\
\text { match, GI } \\
\text { no (score) }\end{array}$ \\
\hline $71^{\prime}$ & GPM1 & 26.68 & 8.27 & 237 & 64 & 32 & $\begin{array}{c}\text { gi|} 15788446 \\
6\end{array}$ & $\begin{array}{c}\text { 5PGM_E } \\
\left(\mathrm{NP} \_012770\right)\end{array}$ & $\begin{array}{l}\text { Cytoplasm } \\
\text { Mitochondrion }\end{array}$ & $\begin{array}{c}\text { Chain } \mathrm{E}, \\
\text { Phosphoglycerate } \\
\text { mutase. }\end{array}$ & $(-)$ \\
\hline 94 & GUS1 & 81.19 & 7.21 & 708 & 103 & 18 & gi|37362649 & NP_o11269 & Cytoplasm & $\begin{array}{c}\text { Glutamyl-tRNA } \\
\text { synthetase (GluRS), } \\
\text { forms a complex with } \\
\text { methionyl-tRNA } \\
\text { synthetase (Mes1p) and } \\
\text { Arc1p; complex formation } \\
\text { increases the catalytic } \\
\text { efficiency of both tRNA } \\
\text { synthetases and ensures } \\
\text { their correct localization to } \\
\text { the cytoplasm. }\end{array}$ & $\begin{array}{c}\text { Ptc1p, } \\
\text { gi|642800 } \\
(33)\end{array}$ \\
\hline $1^{\mathrm{DA}}$ & HSP10 & 11.36 & 8.96 & 106 & 143 & 58 & gi|6324594 & NP_014663 & $\begin{array}{l}\text { Mitochondrion } \\
\text { matrix }\end{array}$ & $\begin{array}{l}\text { Mitochondrial matrix co- } \\
\text { chaperonin that inhibits } \\
\text { the ATPase activity of } \\
\text { Hsp60p, a mitochondrial } \\
\text { chaperonin; involved in } \\
\text { protein folding and sorting } \\
\text { in the mitochondria; } 10 \mathrm{kD} \\
\text { heat shock protein with } \\
\text { similarity to E. coli groES. }\end{array}$ & $\begin{array}{c}\text { Rps10ap, } \\
\text { gi|632486 } \\
7(69)\end{array}$ \\
\hline
\end{tabular}




\begin{tabular}{|c|c|c|c|c|c|c|c|c|c|c|c|}
\hline $\begin{array}{l}\text { Spot } \\
\text { No }\end{array}$ & $\begin{array}{l}\text { Gene } \\
\text { name }\end{array}$ & $\begin{array}{l}\text { Mass } \\
{[\mathrm{kDa}]}\end{array}$ & $\mathrm{p} /[\mathrm{pH}]$ & $\begin{array}{c}\text { Sequence } \\
\text { length } \\
{[A A]}\end{array}$ & Score & $\begin{array}{c}\text { Sequence } \\
\text { Coverage } \\
{[\%]}\end{array}$ & GI No & $\begin{array}{c}\text { Accession No } \\
\text { [SwissProtKB/ } \\
\text { Swiss-Prot/ } \\
\text { S.cerevisiae] } \\
\text { (BLAST } \\
\text { Accession No) }\end{array}$ & $\begin{array}{l}\text { Subcellular } \\
\text { localization }\end{array}$ & Description & $\begin{array}{c}\text { Next } \\
\text { match, GI } \\
\text { no (score) }\end{array}$ \\
\hline $24^{\prime}$ & HTB2 & 14.09 & 10.07 & 130 & 71 & 36 & gi|15988135 & $\begin{array}{c}\text { 1ID3_D } \\
\left(\mathrm{NP} \_009553\right)\end{array}$ & $\begin{array}{l}\text { Chromosome } \\
\text { Nucleus }\end{array}$ & $\begin{array}{l}\text { Chain D, Nucleosome } \\
\text { core particle reveals } \\
\text { fundamental differences } \\
\text { in inter-nucleosome } \\
\text { interactions. }\end{array}$ & $\begin{array}{c}\text { Gly1p, } \\
\text { gi|585212 } \\
\text { (42) }\end{array}$ \\
\hline $134^{\mathrm{DA}}$ & $I D H 1$ & 38.54 & 8.07 & 354 & 143 & 26 & $\begin{array}{c}\text { gi|16701343 } \\
0\end{array}$ & $\begin{array}{c}\text { 3BLV_A } \\
\text { (NP_014361) }\end{array}$ & Mitochondrion & $\begin{array}{l}\text { Chain } A \text {, Isocitrate } \\
\text { dehydrogenase with } \\
\text { citrate bound in the } \\
\text { regulatory subunits. }\end{array}$ & $\begin{array}{c}\text { Conserve } \\
\text { d protein, } \\
\text { gi|151944 } \\
262(26)\end{array}$ \\
\hline $112^{\mathrm{A}}$ & $\mid D P 1$ & 48.21 & 8.42 & 427 & 90 & 23 & $\begin{array}{c}\text { gi|19350651 } \\
1\end{array}$ & $\begin{array}{c}\text { 2QFV_A } \\
\left(\mathrm{NP} \_010217\right)\end{array}$ & Mitochondrion & $\begin{array}{l}\text { Chain A, Mitochondrial } \\
\text { NADP }(+) \text {-dependent } \\
\text { isocitrate dehydrogenase } \\
\text { in complex with NADP(+). }\end{array}$ & $(-)$ \\
\hline $118^{A}$ & ILV3 & 63.39 & 7.92 & 585 & 192 & 19 & gi|6322476 & NP_012550 & Mitochondrion & $\begin{array}{l}\text { Dihydroxyacid } \\
\text { dehydratase,catalyzes } \\
\text { third step in the common } \\
\text { pathway leading to } \\
\text { biosynthesis of branched- } \\
\text { chain amino acids. }\end{array}$ & $\begin{array}{c}\text { YAL039C } \\
\text { p-like } \\
\text { protein, } \\
\text { gi|207348 } \\
032(29)\end{array}$ \\
\hline
\end{tabular}




\begin{tabular}{|c|c|c|c|c|c|c|c|c|c|c|c|}
\hline $\begin{array}{c}\text { Spot } \\
\text { No }\end{array}$ & $\begin{array}{l}\text { Gene } \\
\text { name }\end{array}$ & $\begin{array}{l}\text { Mass } \\
{[\mathrm{kDa}]}\end{array}$ & $\mathrm{p} /[\mathrm{pH}]$ & $\begin{array}{c}\text { Sequence } \\
\text { length } \\
{[\mathrm{AA}]}\end{array}$ & Score & $\begin{array}{c}\text { Sequence } \\
\text { Coverage } \\
{[\%]}\end{array}$ & GI No & $\begin{array}{c}\text { Accession No } \\
\text { [SwissProtKB/ } \\
\text { Swiss-Prot/ } \\
\text { S.cerevisiae] } \\
\text { (BLAST } \\
\text { Accession No) }\end{array}$ & $\begin{array}{l}\text { Subcellular } \\
\text { localization }\end{array}$ & Description & $\begin{array}{c}\text { Next } \\
\text { match, GI } \\
\text { no (score) }\end{array}$ \\
\hline $115^{\mathrm{DA}}$ & IMD2 & 56.95 & 8.71 & 523 & 434 & 26 & gi|6322012 & NP_012088 & Cytoplasm & $\begin{array}{l}\text { Inosine monophosphate } \\
\text { dehydrogenase catalyzes } \\
\text { the rate-limiting step in } \\
\text { GTP biosynthesis, } \\
\text { expression is induced by } \\
\text { mycophenolic acid } \\
\text { resulting in resistance to } \\
\text { the drug, and expression } \\
\text { is repressed by nutrient } \\
\text { limitation. }\end{array}$ & $(-)$ \\
\hline $117^{A}$ & IMD4 & 56.87 & 8.39 & 524 & 313 & 25 & gi|6323585 & NP_013656 & Cytoplasm & $\begin{array}{l}\text { Inosine monophosphate } \\
\text { dehydrogenase catalyzes } \\
\text { the first step of GMP } \\
\text { biosynthesis, member of a } \\
\text { four-gene family in S. } \\
\text { cerevisiae, constitutively } \\
\text { expressed. }\end{array}$ & $\begin{array}{c}\text { Ups3p, } \\
\text { gi|632039 } \\
1 \text { (39) }\end{array}$ \\
\hline 139 & OLA1 & 44.48 & 7.05 & 394 & 234 & 40 & gi|6319499 & NP_009581 & Cytoplasm & $\begin{array}{l}\text { P-loop ATPase with } \\
\text { similarity to human OLA1 } \\
\text { and bacterial YchF; } \\
\text { identified as specifically } \\
\text { interacting with the } \\
\text { proteasome; protein } \\
\text { levels are induced by } \\
\text { hydrogen peroxide. }\end{array}$ & $\begin{array}{c}\text { Ptc7p, } \\
\text { gi|124263 } \\
204(28)\end{array}$ \\
\hline
\end{tabular}




\begin{tabular}{|c|c|c|c|c|c|c|c|c|c|c|c|}
\hline $\begin{array}{l}\text { Spot } \\
\text { No }\end{array}$ & $\begin{array}{l}\text { Gene } \\
\text { name }\end{array}$ & $\begin{array}{l}\text { Mass } \\
{[\mathrm{kDa}]}\end{array}$ & $\mathrm{p} /[\mathrm{pH}]$ & $\begin{array}{l}\text { Sequence } \\
\text { length } \\
{[\mathrm{AA}]}\end{array}$ & Score & $\begin{array}{c}\text { Sequence } \\
\text { Coverage } \\
{[\%]}\end{array}$ & GI No & $\begin{array}{c}\text { Accession No } \\
\text { [SwissProtKB/ } \\
\text { Swiss-Prot/ } \\
\text { S.cerevisiae] } \\
\text { (BLAST } \\
\text { Accession No) }\end{array}$ & $\begin{array}{l}\text { Subcellular } \\
\text { localization }\end{array}$ & Description & $\begin{array}{c}\text { Next } \\
\text { match, GI } \\
\text { no (score) }\end{array}$ \\
\hline $151^{\mathrm{DA}}$ & PGK1 & 44.76 & 7.11 & 416 & 274 & 45 & gi|10383781 & NP_009938 & Cytoplasm & $\begin{array}{l}\text { 3-phosphoglycerate } \\
\text { kinase, catalyzes transfer } \\
\text { of high-energy phosphoryl } \\
\text { groups from the acyl } \\
\text { phosphate of 1,3- } \\
\text { bisphosphoglycerate to } \\
\text { ADP to produce ATP; key } \\
\text { enzyme in glycolysis and } \\
\text { gluconeogenesis. }\end{array}$ & $\begin{array}{c}\text { Spindle } \\
\text { pole } \\
\text { compone } \\
\text { nt, } \\
\text { gi|151942 } \\
674(33)\end{array}$ \\
\hline $124 I$ & PGK1 & 44.59 & 7.1 & 415 & 163 & 28 & $\begin{array}{c}\text { gi|} 15783686 \\
7\end{array}$ & $\begin{array}{c}\text { 3PGK_A } \\
\text { (NP_009938) }\end{array}$ & Cytoplasm & $\begin{array}{c}\text { Chain A, } \\
\text { Phosphoglycerate kinase. }\end{array}$ & $(-)$ \\
\hline $145^{\mathrm{DA}}$ & $P G K 1$ & 44.59 & 7.1 & 415 & 158 & 23 & $\begin{array}{c}\text { gi|15783686 } \\
7\end{array}$ & $\begin{array}{c}\text { 3PGK_A } \\
\text { (NP_009938) }\end{array}$ & Cytoplasm & $\begin{array}{c}\text { Chain A, } \\
\text { Phosphoglycerate kinase. }\end{array}$ & $\begin{array}{c}\text { SCY }_{1} 403 \\
\text { gi| } 151940 \\
675(26)\end{array}$ \\
\hline 64 & PGK1 & 44.6 & 6.73 & 415 & 154 & 16 & $\begin{array}{c}\text { gi|} 15783361 \\
0\end{array}$ & $\begin{array}{c}\text { 1QPG_A } \\
\text { (NP_009938) }\end{array}$ & Cytoplasm & $\begin{array}{c}\text { Chain } A, 3- \\
\text { Phosphoglycerate kinase, } \\
\text { mutation R65q. }\end{array}$ & $\begin{array}{c}\text { Rps7ap, } \\
\text { gi|632467 } \\
0 \text { (109) }\end{array}$ \\
\hline $147^{1 \mathrm{~A}}$ & PGK1 & 44.6 & 6.73 & 415 & 115 & 18 & $\begin{array}{c}\text { gi|15783361 } \\
0\end{array}$ & $\begin{array}{c}\text { 1QPG_A } \\
\text { (NP_009938) }\end{array}$ & Cytoplasm & $\begin{array}{l}\text { Chain A, 3- } \\
\text { Phosphoglycerate kinase, } \\
\text { mutation R65q. }\end{array}$ & $\begin{array}{c}\text { Cit1p, } \\
\text { gi|632432 } \\
8(102)\end{array}$ \\
\hline
\end{tabular}




\begin{tabular}{|c|c|c|c|c|c|c|c|c|c|c|c|}
\hline $\begin{array}{l}\text { Spot } \\
\text { No }\end{array}$ & $\begin{array}{l}\text { Gene } \\
\text { name }\end{array}$ & $\begin{array}{l}\text { Mass } \\
{[\mathrm{kDa}]}\end{array}$ & $\mathrm{p} /[\mathrm{pH}]$ & $\begin{array}{c}\text { Sequence } \\
\text { length } \\
{[A A]}\end{array}$ & Score & $\begin{array}{c}\text { Sequence } \\
\text { Coverage } \\
{[\%]}\end{array}$ & GI No & $\begin{array}{c}\text { Accession No } \\
\text { [SwissProtKB/ } \\
\text { Swiss-Prot/ } \\
\text { S.cerevisiae] } \\
\text { (BLAST } \\
\text { Accession No) }\end{array}$ & $\begin{array}{l}\text { Subcellular } \\
\text { localization }\end{array}$ & Description & $\begin{array}{c}\text { Next } \\
\text { match, GI } \\
\text { no (score) }\end{array}$ \\
\hline 35 & PHB2 & 34.44 & 9.92 & 310 & 56 & 18 & gi|50593217 & NP_011747 & $\begin{array}{l}\text { Mitochondrion } \\
\text { inner membrane }\end{array}$ & $\begin{array}{l}\text { Subunit of the prohibitin } \\
\text { complex (Phb1p-Phb2p), } \\
\text { a 1.2 MDa ring-shaped } \\
\text { inner mitochondrial } \\
\text { membrane chaperone } \\
\text { that stabilizes newly } \\
\text { synthesized proteins; } \\
\text { determinant of replicative } \\
\text { life span; involved in } \\
\text { mitochondrial } \\
\text { segregation. }\end{array}$ & None \\
\hline $25^{\prime}$ & $\begin{array}{c}\text { RPL11 } \\
A\end{array}$ & 18.79 & 9.91 & 165 & 392 & 32 & $\begin{array}{c}\text { gi } \mid 11939053 \\
0\end{array}$ & $\begin{array}{c}\text { 2NOQ_H } \\
\left(\mathrm{NP} \_015427\right)\end{array}$ & Cytoplasm & $\begin{array}{l}\text { Protein of the large } 60 S \\
\text { ribosomal subunit, nearly } \\
\text { identical to Rpl11Bp but } \\
\text { expressed at twice the } \\
\text { level; involved in } \\
\text { ribosomal assembly; } \\
\text { depletion causes } \\
\text { degradation of } 60 S \\
\text { proteins and RNA; similar } \\
\text { to E. coli L5 and rat L11. }\end{array}$ & $\begin{array}{l}\text { FUN20, } \\
\text { gi|5241 } \\
(47)\end{array}$ \\
\hline
\end{tabular}




\begin{tabular}{|c|c|c|c|c|c|c|c|c|c|c|c|}
\hline $\begin{array}{l}\text { Spot } \\
\text { No }\end{array}$ & $\begin{array}{l}\text { Gene } \\
\text { name }\end{array}$ & $\begin{array}{l}\text { Mass } \\
{[\mathrm{kDa}]}\end{array}$ & $\mathrm{p} /[\mathrm{pH}]$ & $\begin{array}{c}\text { Sequence } \\
\text { length } \\
{[A A]}\end{array}$ & Score & $\begin{array}{c}\text { Sequence } \\
\text { Coverage } \\
{[\%]}\end{array}$ & GI No & $\begin{array}{c}\text { Accession No } \\
\text { [SwissProtKB/ } \\
\text { Swiss-Prot/ } \\
\text { S.cerevisiae] } \\
\text { (BLAST } \\
\text { Accession No) }\end{array}$ & $\begin{array}{l}\text { Subcellular } \\
\text { localization }\end{array}$ & Description & $\begin{array}{c}\text { Next } \\
\text { match, GI } \\
\text { no (score) }\end{array}$ \\
\hline $28^{1}$ & $\begin{array}{c}\text { RPL12 } \\
B\end{array}$ & 17.86 & 9.43 & 165 & 99 & 27 & gi|6320625 & NP_010706 & Cytoplasm & $\begin{array}{l}\text { Protein component of the } \\
\text { large (60S) ribosomal } \\
\text { subunit, nearly identical to } \\
\text { Rpl12Ap; rpl12a rpl12b } \\
\text { double mutant exhibits } \\
\text { slow growth and slow } \\
\text { translation; has similarity } \\
\text { to E. coli L11 and rat L12 } \\
\text { ribosomal proteins. }\end{array}$ & $(-)$ \\
\hline $75^{1 \mathrm{~A}}$ & $\begin{array}{l}R P L 13 \\
\quad A\end{array}$ & 22.4 & 11.18 & 198 & 122 & 20 & $\begin{array}{c}\text { gi|19040508 } \\
8\end{array}$ & $\begin{array}{c}\text { EDV08355 } \\
\text { (NP_010201) }\end{array}$ & Cytoplasm & Ribosomal protein L13A. & $\begin{array}{c}\text { Tdh3p, } \\
\text { gi|632163 } \\
1(62)\end{array}$ \\
\hline $56^{1 \mathrm{~A}}$ & $\begin{array}{c}\text { RPL13 } \\
\quad B\end{array}$ & 22.51 & 11.08 & 199 & 82 & 35 & gi|6323791 & NP_013862 & Cytoplasm & $\begin{array}{l}\text { Protein component of the } \\
\text { large (60S) ribosomal } \\
\text { subunit, nearly identical to } \\
\text { Rpl13Ap; not essential for } \\
\text { viability; has similarity to } \\
\text { rat } L 13 \text { ribosomal protein }\end{array}$ & $\begin{array}{c}\text { Pau9p, } \\
\text { gi|131291 } \\
51(36)\end{array}$ \\
\hline $18^{1 \mathrm{~A}}$ & RPS15 & 8.88 & 9.9 & 80 & 70 & 16 & gi|49258836 & $\begin{array}{c}\text { 1S1H_S } \\
(\mathrm{NP} \text { 014602) }\end{array}$ & Cytoplasm & $\begin{array}{c}\text { Chain S, Ribosomal 80s- } \\
\text { Eef2-sordarin complex } \\
\text { obtained by docking } \\
\text { atomic models for RNA } \\
\text { and protein components } \\
\text { Into a } 11.7 \mathrm{~A} \text { cryo-em } \\
\text { map. }\end{array}$ & $\begin{array}{c}\text { Rps15p, } \\
\text { gi|632453 } \\
3(68)\end{array}$ \\
\hline
\end{tabular}




\begin{tabular}{|c|c|c|c|c|c|c|c|c|c|c|c|}
\hline $\begin{array}{l}\text { Spot } \\
\text { No }\end{array}$ & $\begin{array}{l}\text { Gene } \\
\text { name }\end{array}$ & $\begin{array}{l}\text { Mass } \\
{[\mathrm{kDa}]}\end{array}$ & $\mathrm{p} /[\mathrm{pH}]$ & $\begin{array}{c}\text { Sequence } \\
\text { length } \\
{[A A]}\end{array}$ & Score & $\begin{array}{c}\text { Sequence } \\
\text { Coverage } \\
{[\%]}\end{array}$ & GI No & $\begin{array}{c}\text { Accession No } \\
\text { [SwissProtKB/ } \\
\text { Swiss-Prot/ } \\
\text { S.cerevisiae] } \\
\text { (BLAST } \\
\text { Accession No) }\end{array}$ & $\begin{array}{l}\text { Subcellular } \\
\text { localization }\end{array}$ & Description & $\begin{array}{c}\text { Next } \\
\text { match, GI } \\
\text { no (score) }\end{array}$ \\
\hline 16 & $\begin{array}{c}\text { RPS19 } \\
B\end{array}$ & 15.88 & 9.61 & 144 & 205 & 61 & gi|6324027 & NP_014097 & Cytoplasm & $\begin{array}{l}\text { Protein component of the } \\
\text { small (40S) ribosomal } \\
\text { subunit, required for } \\
\text { assembly and maturation } \\
\text { of pre-40 S particles; } \\
\text { mutations in human } \\
\text { RPS19 are associated } \\
\text { with Diamond } \\
\text { Blackfananemia; nearly } \\
\text { identical to Rps19Ap. }\end{array}$ & $\begin{array}{c}\text { Eno2p, } \\
\text { gi|632196 } \\
8(123)\end{array}$ \\
\hline $20^{\mathrm{IA}}$ & RPS20 & 13.89 & 9.52 & 121 & 249 & 54 & gi|6321772 & NP_011848 & Cytoplasm & $\begin{array}{l}\text { Protein component of the } \\
\text { small (40S) ribosomal } \\
\text { subunit; overproduction } \\
\text { suppresses mutations } \\
\text { affecting RNA polymerase } \\
\text { III-dependent } \\
\text { transcription; has } \\
\text { similarity to E. coli S10 } \\
\text { and rat S20 ribosomal } \\
\text { proteins. }\end{array}$ & $\begin{array}{c}\text { AWRI163 } \\
1 \_22090, \\
\text { gi|207347 } \\
659(33)\end{array}$ \\
\hline $21^{1 \mathrm{~A}}$ & $\begin{array}{c}R P S 22 \\
A\end{array}$ & 14.53 & 9.94 & 129 & 153 & 29 & gi|49258827 & $\begin{array}{c}\text { 1S1H_H } \\
\left(\mathrm{NP} \_012345\right)\end{array}$ & Cytoplasm & $\begin{array}{c}\text { Chain H, Ribosomal 80s- } \\
\text { Eef2-Sordarin Complex } \\
\text { obtained by docking } \\
\text { atomic models for RNA } \\
\text { and protein components } \\
\text { into a 11.7 A Cryo-Em } \\
\text { Map. }\end{array}$ & $\begin{array}{c}\text { Faf1p, } \\
\text { gi|632217 } \\
0(33)\end{array}$ \\
\hline
\end{tabular}




\begin{tabular}{|c|c|c|c|c|c|c|c|c|c|c|c|}
\hline $\begin{array}{l}\text { Spot } \\
\text { No }\end{array}$ & $\begin{array}{l}\text { Gene } \\
\text { name }\end{array}$ & $\begin{array}{l}\text { Mass } \\
{[\mathrm{kDa}]}\end{array}$ & $\mathrm{p} /[\mathrm{pH}]$ & $\begin{array}{c}\text { Sequence } \\
\text { length } \\
{[A A]}\end{array}$ & Score & $\begin{array}{c}\text { Sequence } \\
\text { Coverage } \\
{[\%]}\end{array}$ & GI No & $\begin{array}{c}\text { Accession No } \\
\text { [SwissProtKB/ } \\
\text { Swiss-Prot/ } \\
\text { S.cerevisiae] } \\
\text { (BLAST } \\
\text { Accession No) }\end{array}$ & $\begin{array}{l}\text { Subcellular } \\
\text { localization }\end{array}$ & Description & $\begin{array}{c}\text { Next } \\
\text { match, GI } \\
\text { no (score) }\end{array}$ \\
\hline $9^{\mathrm{DB}}$ & $\begin{array}{l}R P S 27 \\
A\end{array}$ & 9.02 & 9.37 & 81 & 104 & 38 & gi|2131116 & CAA81997 & Cytoplasm & $\begin{array}{c}40 \text { S ribosomal protein } \\
\text { S27-A. }\end{array}$ & $\begin{array}{c}\text { YLR146W } \\
-A, \\
\text { gi|827952 } \\
59(26)\end{array}$ \\
\hline $41^{\mathrm{AA}}$ & RPS3 & 26.54 & 9.42 & 240 & 83 & 54 & gi|6324151 & NP_014221 & Cytoplasm & $\begin{array}{l}\text { Protein component of the } \\
\text { small (40S) ribosomal } \\
\text { subunit has } \\
\text { apurinic/apyrimidinic (AP) } \\
\text { endonuclease activity; } \\
\text { essential for viability; has } \\
\text { similarity to E.coli S3 and } \\
\text { rat S3 ribosomal proteins. }\end{array}$ & $\begin{array}{c}\text { Ics2p, } \\
\text { gi|302677 } \\
48(30)\end{array}$ \\
\hline $39^{\mathrm{D}}$ & RPS4B & 29.44 & 10.09 & 261 & 144 & 33 & gi|6321997 & NP_012073 & Cytoplasm & $\begin{array}{l}\text { Protein component of the } \\
\text { small ( } 40 \mathrm{~S} \text { ) ribosomal } \\
\text { subunit; identical to } \\
\text { Rps4Ap and has similarity } \\
\text { to rat S4 ribosomal } \\
\text { protein. }\end{array}$ & $\begin{array}{c}\text { Tex1p, } \\
\text { gi|632407 } \\
6(37)\end{array}$ \\
\hline $53^{1 \mathrm{~A}}$ & RPS5 & 25.08 & 8.63 & 225 & 217 & 35 & gi|6322583 & NP_012657 & Cytoplasm & $\begin{array}{l}\text { Protein component of the } \\
\text { small ( } 40 S \text { ) ribosomal } \\
\text { subunit, the least basic of } \\
\text { the non-acidic ribosomal } \\
\text { proteins; phosphorylated } \\
\text { in vivo; essential for } \\
\text { viability; has similarity to } \\
\text { E. coli S7 and rat S5 } \\
\text { ribosomal proteins. }\end{array}$ & $\begin{array}{c}\text { Rpl13bp, } \\
\text { gi|632379 } \\
1(28)\end{array}$ \\
\hline
\end{tabular}




\begin{tabular}{|c|c|c|c|c|c|c|c|c|c|c|c|}
\hline $\begin{array}{l}\text { Spot } \\
\text { No }\end{array}$ & $\begin{array}{l}\text { Gene } \\
\text { name }\end{array}$ & $\begin{array}{l}\text { Mass } \\
{[\mathrm{kDa}]}\end{array}$ & $\mathrm{p} /[\mathrm{pH}]$ & $\begin{array}{c}\text { Sequence } \\
\text { length } \\
{[A A]}\end{array}$ & Score & $\begin{array}{c}\text { Sequence } \\
\text { Coverage } \\
{[\%]}\end{array}$ & GI No & $\begin{array}{c}\text { Accession No } \\
\text { [SwissProtKB/ } \\
\text { Swiss-Prot/ } \\
\text { S.cerevisiae] } \\
\text { (BLAST } \\
\text { Accession No) }\end{array}$ & $\begin{array}{l}\text { Subcellular } \\
\text { localization }\end{array}$ & Description & $\begin{array}{c}\text { Next } \\
\text { match, GI } \\
\text { no (score) }\end{array}$ \\
\hline $51^{1 \mathrm{~A}}$ & RPS5 & 25.08 & 8.63 & 225 & 56 & 23 & gi|6322583 & NP_012657 & Cytoplasm & $\begin{array}{l}\text { Protein component of the } \\
\text { small (40S) ribosomal } \\
\text { subunit, the least basic of } \\
\text { the non-acidic ribosomal } \\
\text { proteins; phosphorylated } \\
\text { in vivo; essential for } \\
\text { viability; has similarity to } \\
\text { E. coli S7 and rat S5 } \\
\text { ribosomal proteins. }\end{array}$ & None \\
\hline $63^{\mathrm{IA}}$ & RPS7A & 21.6 & 9.83 & 190 & 161 & 22 & gi|6324670 & NP_014739 & $\begin{array}{l}\text { Cytoplasm } \\
\text { Nucleus > } \\
\text { nucleolus }\end{array}$ & $\begin{array}{l}\text { Protein component of the } \\
\text { small (40S) ribosomal } \\
\text { subunit, nearly identical to } \\
\text { Rps7Bp; interacts with } \\
\text { Kti11p; deletion causes } \\
\text { hypersensitivity to } \\
\text { zymocin; has similarity to } \\
\text { rat S7 and Xenopus S8 } \\
\text { ribosomal proteins. }\end{array}$ & $\begin{array}{c}\text { Rpl16bp, } \\
\text { gi|632426 } \\
0(54)\end{array}$ \\
\hline
\end{tabular}




\begin{tabular}{|c|c|c|c|c|c|c|c|c|c|c|c|}
\hline $\begin{array}{l}\text { Spot } \\
\text { No }\end{array}$ & $\begin{array}{l}\text { Gene } \\
\text { name }\end{array}$ & $\begin{array}{l}\text { Mass } \\
{[\mathrm{kDa}]}\end{array}$ & $\mathrm{p} /[\mathrm{pH}]$ & $\begin{array}{c}\text { Sequence } \\
\text { length } \\
{[A A]}\end{array}$ & Score & $\begin{array}{c}\text { Sequence } \\
\text { Coverage } \\
{[\%]}\end{array}$ & GI No & $\begin{array}{c}\text { Accession No } \\
\text { [SwissProtKB/ } \\
\text { Swiss-Prot/ } \\
\text { S.cerevisiae] } \\
\text { (BLAST } \\
\text { Accession No) }\end{array}$ & $\begin{array}{l}\text { Subcellular } \\
\text { localization }\end{array}$ & Description & $\begin{array}{c}\text { Next } \\
\text { match, GI } \\
\text { no (score) }\end{array}$ \\
\hline $86^{\mathrm{A}}$ & RPT6 & 45.47 & 9.09 & 405 & 57 & 22 & gil6321390 & NP_011467 & $\begin{array}{l}\text { Cytoplasm } \\
\text { Nucleus }\end{array}$ & $\begin{array}{l}\text { One of six ATPases of the } \\
\text { 19S regulatory particle of } \\
\text { the } 26 S \text { proteasome } \\
\text { involved in the } \\
\text { degradation of } \\
\text { ubiquitinated substrates; } \\
\text { bound by ubiquitin-protein } \\
\text { ligases Ubr1p and Ufd } 4 p ; \\
\text { localized mainly to the } \\
\text { nucleus throughout the } \\
\text { cell cycle. }\end{array}$ & $\begin{array}{c}\text { SUG1 } \\
\text { gene, } \\
\text { gi|228885 } \\
\text { (52) }\end{array}$ \\
\hline $136^{A}$ & SHM1 & 53.88 & 8.83 & 490 & 79 & 13 & gi|37362622 & NP_009822 & Mitochondrion & $\begin{array}{c}\text { Mitochondrial serine } \\
\text { hydroxymethyl } \\
\text { transferase, converts } \\
\text { serine to glycine plus } \\
5,10 \text { methylenetetrahydrof } \\
\text { olate; involved in } \\
\text { generating precursors for } \\
\text { purine, pyrimidine, amino } \\
\text { acid, and lipid } \\
\text { biosynthesis; reverse } \\
\text { reaction generates serine. }\end{array}$ & $\begin{array}{c}\text { Chain A, } \\
\text { Pi-Scei, } \\
\text { gi|311441 } \\
0(50)\end{array}$ \\
\hline
\end{tabular}




\begin{tabular}{|c|c|c|c|c|c|c|c|c|c|c|c|}
\hline $\begin{array}{l}\text { Spot } \\
\text { No }\end{array}$ & $\begin{array}{l}\text { Gene } \\
\text { name }\end{array}$ & $\begin{array}{l}\text { Mass } \\
{[\mathrm{kDa}]}\end{array}$ & $\mathrm{p} /[\mathrm{pH}]$ & $\begin{array}{c}\text { Sequence } \\
\text { length } \\
{[A A]}\end{array}$ & Score & $\begin{array}{c}\text { Sequence } \\
\text { Coverage } \\
{[\%]}\end{array}$ & GI No & $\begin{array}{c}\text { Accession No } \\
\text { [SwissProtKB/ } \\
\text { Swiss-Prot/ } \\
\text { S.cerevisiae] } \\
\text { (BLAST } \\
\text { Accession No) }\end{array}$ & $\begin{array}{l}\text { Subcellular } \\
\text { localization }\end{array}$ & Description & $\begin{array}{c}\text { Next } \\
\text { match, GI } \\
\text { no (score) }\end{array}$ \\
\hline $142^{\mathrm{D}}$ & SHM2 & 52.47 & 6.98 & 469 & 248 & 34 & gi|6323087 & $N P \_013159$ & Cytoplasm & $\begin{array}{l}\text { Cytoplasmic serine } \\
\text { hydroxymethyl } \\
\text { transferase, converts } \\
\text { serine to glycine plus } \\
5,10 \text { methylenetetrahydrof } \\
\text { olate; major isoform } \\
\text { involved in generating } \\
\text { precursors for purine, } \\
\text { pyrimidine, amino acid, } \\
\text { and lipid biosynthesis. }\end{array}$ & $\begin{array}{c}\text { YKL081W } \\
\text { p-like } \\
\text { protein, } \\
\text { gi|207343 } \\
526(83)\end{array}$ \\
\hline 87 & SIS1 & 37.56 & 9.02 & 352 & 272 & 37 & gi|6324321 & NP_014391 & $\begin{array}{c}\text { Cytoplasm } \\
\text { Nucleus }\end{array}$ & $\begin{array}{l}\text { Type II HSP40 co- } \\
\text { chaperone that interacts } \\
\text { with the HSP70 protein } \\
\text { Ssa1p; not functionally } \\
\text { redundant with Ydj1p due } \\
\text { to due to substrate } \\
\text { specificity; shares } \\
\text { similarity with bacterial } \\
\text { DNAJ proteins. }\end{array}$ & $\begin{array}{c}\text { Eis1p, } \\
\text { gi|632367 } \\
4(33)\end{array}$ \\
\hline
\end{tabular}




\begin{tabular}{|c|c|c|c|c|c|c|c|c|c|c|c|}
\hline $\begin{array}{l}\text { Spot } \\
\text { No }\end{array}$ & $\begin{array}{l}\text { Gene } \\
\text { name }\end{array}$ & $\begin{array}{l}\text { Mass } \\
{[\mathrm{kDa}]}\end{array}$ & $\mathrm{p} /[\mathrm{pH}]$ & $\begin{array}{c}\text { Sequence } \\
\text { length } \\
{[A A]}\end{array}$ & Score & $\begin{array}{c}\text { Sequence } \\
\text { Coverage } \\
{[\%]}\end{array}$ & GI No & $\begin{array}{c}\text { Accession No } \\
\text { [SwissProtKB/ } \\
\text { Swiss-Prot/ } \\
\text { S.cerevisiae] } \\
\text { (BLAST } \\
\text { Accession No) }\end{array}$ & $\begin{array}{l}\text { Subcellular } \\
\text { localization }\end{array}$ & Description & $\begin{array}{c}\text { Next } \\
\text { match, GI } \\
\text { no (score) }\end{array}$ \\
\hline $80^{1 \mathrm{~A}}$ & STM1 & 29.97 & 9.66 & 273 & 189 & 26 & gil6323179 & NP_013251 & $\begin{array}{c}\text { Cytoplasm } \\
\text { Nucleus }\end{array}$ & $\begin{array}{l}\text { Protein required for } \\
\text { optimal translation under } \\
\text { nutrient stress; perturbs } \\
\text { association of Yef3p with } \\
\text { ribosomes; involved in } \\
\text { TOR signaling; binds G4 } \\
\text { quadruplex and purine } \\
\text { motif triplex nucleic acid; } \\
\text { helps maintain telomere } \\
\text { structure. }\end{array}$ & $\begin{array}{c}\text { Chain } \mathrm{P} \text {, } \\
\mathrm{N}- \\
\text { terminal } \\
\text { domain of } \\
\text { Tlg1 } \\
\text { complexe } \\
\text { d with } \mathrm{N}- \\
\text { terminus } \\
\text { of Vps51, } \\
\text { gi|881925 } \\
65(30)\end{array}$ \\
\hline $132^{\mathrm{DA}}$ & $T D H 1$ & 35.84 & 8.29 & 332 & 161 & 31 & gi|6322409 & NP_012483 & Cytoplasm & $\begin{array}{c}\text { Glyceraldehyde-3- } \\
\text { phosphate } \\
\text { dehydrogenase, isozyme } \\
1 \text {, involved in glycolysis } \\
\text { and gluconeogenesis; } \\
\text { tetramer that catalyzes } \\
\text { the reaction of } \\
\text { glyceraldehyde-3- } \\
\text { phosphate to 1,3bis- } \\
\text { phosphoglycerate. }\end{array}$ & $\begin{array}{c}\text { Tar1p, } \\
\text { gi|232703 } \\
99(30)\end{array}$ \\
\hline
\end{tabular}




\begin{tabular}{|c|c|c|c|c|c|c|c|c|c|c|c|}
\hline $\begin{array}{l}\text { Spot } \\
\text { No }\end{array}$ & $\begin{array}{l}\text { Gene } \\
\text { name }\end{array}$ & $\begin{array}{l}\text { Mass } \\
{[\mathrm{kDa}]}\end{array}$ & $\mathrm{p} /[\mathrm{pH}]$ & $\begin{array}{c}\text { Sequence } \\
\text { length } \\
{[A A]}\end{array}$ & Score & $\begin{array}{c}\text { Sequence } \\
\text { Coverage } \\
{[\%]}\end{array}$ & GI No & $\begin{array}{c}\text { Accession No } \\
\text { [SwissProtKB/ } \\
\text { Swiss-Prot/ } \\
\text { S.cerevisiae] } \\
\text { (BLAST } \\
\text { Accession No) }\end{array}$ & $\begin{array}{l}\text { Subcellular } \\
\text { localization }\end{array}$ & Description & $\begin{array}{c}\text { Next } \\
\text { match, GI } \\
\text { no (score) }\end{array}$ \\
\hline $128^{\mathrm{D}}$ & TDH3 & 35.83 & 6.46 & 332 & 110 & 25 & gi|6321631 & NP_011708 & Cytoplasm & $\begin{array}{c}\text { Glyceraldehyde-3- } \\
\text { phosphate } \\
\text { dehydrogenase, isozyme } \\
\text { 3, involved in glycolysis } \\
\text { and gluconeogenesis; } \\
\text { tetramer that catalyzes } \\
\text { the reaction of } \\
\text { glyceraldehyde-3- } \\
\text { phosphate to } 1,3 \mathrm{bis}- \\
\text { phosphoglycerate. }\end{array}$ & $(-)$ \\
\hline $43^{\mathrm{DB}}$ & TDH3 & 35.83 & 6.46 & 332 & 89 & 12 & gi|6321631 & NP_011708 & Cytoplasm & $\begin{array}{c}\text { Glyceraldehyde-3- } \\
\text { phosphate } \\
\text { dehydrogenase, isozyme } \\
\text { 3, involved in glycolysis } \\
\text { and gluconeogenesis; } \\
\text { tetramer that catalyzes } \\
\text { the reaction of } \\
\text { glyceraldehyde-3- } \\
\text { phosphate to 1,3bis- } \\
\text { phosphoglycerate. }\end{array}$ & $\begin{array}{c}\text { Erp6p, } \\
\text { gi|632143 } \\
6(31)\end{array}$ \\
\hline
\end{tabular}




\begin{tabular}{|c|c|c|c|c|c|c|c|c|c|c|c|}
\hline $\begin{array}{l}\text { Spot } \\
\text { No }\end{array}$ & $\begin{array}{l}\text { Gene } \\
\text { name }\end{array}$ & $\begin{array}{l}\text { Mass } \\
{[\mathrm{kDa}]}\end{array}$ & $\mathrm{p} /[\mathrm{pH}]$ & $\begin{array}{c}\text { Sequence } \\
\text { length } \\
{[\mathrm{AA}]}\end{array}$ & Score & $\begin{array}{c}\text { Sequence } \\
\text { Coverage } \\
{[\%]}\end{array}$ & GI No & $\begin{array}{c}\text { Accession No } \\
\text { [SwissProtKB/ } \\
\text { Swiss-Prot/ } \\
\text { S.cerevisiae] } \\
\text { (BLAST } \\
\text { Accession No) }\end{array}$ & $\begin{array}{l}\text { Subcellular } \\
\text { localization }\end{array}$ & Description & $\begin{array}{c}\text { Next } \\
\text { match, GI } \\
\text { no (score) }\end{array}$ \\
\hline $152^{\mathrm{D}}$ & $T D H 3$ & 35.83 & 6.46 & 332 & 56 & 18 & gi|6321631 & NP_011708 & Cytoplasm & $\begin{array}{c}\text { Glyceraldehyde-3- } \\
\text { phosphate } \\
\text { dehydrogenase, isozyme } \\
\text { 3, involved in glycolysis } \\
\text { and gluconeogenesis; } \\
\text { tetramer that catalyzes } \\
\text { the reaction of } \\
\text { glyceraldehyde-3- } \\
\text { phosphate to } 1,3 \text { bis- } \\
\text { phosphoglycerate. }\end{array}$ & $(-)$ \\
\hline $153^{\mathrm{D}}$ & TEF2 & 50.4 & 9.14 & 458 & 328 & 40 & gi|6319594 & NP_009676 & Cytoplasm & $\begin{array}{l}\text { Translational elongation } \\
\text { factor EF-1 alpha; also } \\
\text { encoded by TEF1; } \\
\text { functions in the binding } \\
\text { reaction of aminoacyl- } \\
\text { tRNA (AA-tRNA) to } \\
\text { ribosomes; may also have } \\
\text { a role in tRNA re-export } \\
\text { from the nucleus. }\end{array}$ & $\begin{array}{c}\text { Chain B, } \\
\text { Sec23- } \\
\text { Sar1 } \\
\text { complexe } \\
\text { d with the } \\
\text { active } \\
\text { fragment } \\
\text { of Sec31, } \\
\text { gi|165761 } \\
045(32)\end{array}$ \\
\hline $83^{\mathrm{D}}$ & TEF2 & 50.4 & 9.14 & 458 & 88 & 9 & gi|6319594 & NP_009676 & Cytoplasm & $\begin{array}{l}\text { Translational elongation } \\
\text { factor EF-1 alpha; also } \\
\text { encoded by TEF1; } \\
\text { functions in the binding } \\
\text { reaction of aminoacyl- } \\
\text { tRNA (AA-tRNA) to } \\
\text { ribosomes; may also have } \\
\text { a role in tRNA re-export } \\
\text { from the nucleus. }\end{array}$ & $\begin{array}{c}\text { YAR042 } \\
\text { Wp, } \\
\text { gi|302677 } \\
74(29)\end{array}$ \\
\hline
\end{tabular}




\begin{tabular}{|c|c|c|c|c|c|c|c|c|c|c|c|}
\hline $\begin{array}{l}\text { Spot } \\
\text { No }\end{array}$ & $\begin{array}{l}\text { Gene } \\
\text { name }\end{array}$ & $\begin{array}{l}\text { Mass } \\
{[\mathrm{kDa}]}\end{array}$ & $\mathrm{p} /[\mathrm{pH}]$ & $\begin{array}{c}\text { Sequence } \\
\text { length } \\
{[A A]}\end{array}$ & Score & $\begin{array}{c}\text { Sequence } \\
\text { Coverage } \\
{[\%]}\end{array}$ & GI No & $\begin{array}{c}\text { Accession No } \\
\text { [SwissProtKB/ } \\
\text { Swiss-Prot/ } \\
\text { S.cerevisiae] } \\
\text { (BLAST } \\
\text { Accession No) }\end{array}$ & $\begin{array}{l}\text { Subcellular } \\
\text { localization }\end{array}$ & Description & $\begin{array}{c}\text { Next } \\
\text { match, GI } \\
\text { no (score) }\end{array}$ \\
\hline $82^{\mathrm{D}}$ & TEF2 & 50.4 & 9.14 & 458 & 59 & 8 & gi|6319594 & NP_009676 & Cytoplasm & $\begin{array}{l}\text { Translational elongation } \\
\text { factor EF-1 alpha; also } \\
\text { encoded by TEF1; } \\
\text { functions in the binding } \\
\text { reaction of aminoacyl- } \\
\text { tRNA (AA-tRNA) to } \\
\text { ribosomes; may also have } \\
\text { a role in tRNA re-export } \\
\text { from the nucleus. }\end{array}$ & $(-)$ \\
\hline $68^{\mathrm{DB}}$ & TEF2 & 41.54 & 8.36 & 376 & 114 & 15 & gi|32693297 & $\begin{array}{l}\text { AAM83114 } \\
\left(\mathrm{NP} \_009676\right)\end{array}$ & Cytoplasm & $\begin{array}{l}\text { Translation elongation } \\
\text { factor 1-alpha. }\end{array}$ & $\begin{array}{l}\text { Chain B, } \\
\text { Sec23- } \\
\text { Sar1 } \\
\text { complexe } \\
\text { d with the } \\
\text { active } \\
\text { fragment } \\
\text { of Sec31, } \\
\text { gil165761 } \\
045(34)\end{array}$ \\
\hline $85^{\mathrm{IB}}$ & TEF2 & 31.6 & 7.22 & 289 & 103 & 13 & $\begin{array}{c}\text { gi|} 15989524 \\
2\end{array}$ & $\begin{array}{l}\text { ABX09905 } \\
\left(\mathrm{NP} \_009676\right)\end{array}$ & Cytoplasm & $\begin{array}{l}\text { Translation elongation } \\
\text { factor 1-alpha. }\end{array}$ & $(-)$ \\
\hline $106^{\mathrm{D}}$ & TEF2 & 40.56 & 8.13 & 367 & 66 & 23 & gi|32693293 & $\begin{array}{l}\text { AAM83112 } \\
(\text { NP_009676) }\end{array}$ & Cytoplasm & $\begin{array}{l}\text { Translation elongation } \\
\text { factor 1-alpha. }\end{array}$ & $(-)$ \\
\hline
\end{tabular}




\begin{tabular}{|c|c|c|c|c|c|c|c|c|c|c|c|}
\hline $\begin{array}{l}\text { Spot } \\
\text { No }\end{array}$ & $\begin{array}{l}\text { Gene } \\
\text { name }\end{array}$ & $\begin{array}{l}\text { Mass } \\
{[\mathrm{kDa}]}\end{array}$ & $\mathrm{p} /[\mathrm{pH}]$ & $\begin{array}{c}\text { Sequence } \\
\text { length } \\
{[A A]}\end{array}$ & Score & $\begin{array}{c}\text { Sequence } \\
\text { Coverage } \\
{[\%]}\end{array}$ & GI No & $\begin{array}{c}\text { Accession No } \\
\text { [SwissProtKB/ } \\
\text { Swiss-Prot/ } \\
\text { S.cerevisiae] } \\
\text { (BLAST } \\
\text { Accession No) }\end{array}$ & $\begin{array}{l}\text { Subcellular } \\
\text { localization }\end{array}$ & Description & $\begin{array}{c}\text { Next } \\
\text { match, GI } \\
\text { no (score) }\end{array}$ \\
\hline $123^{\mathrm{DA}}$ & TEF4 & 46.5 & 7.63 & 411 & 182 & 23 & gi|538258 & $\begin{array}{c}\text { AAA21473 } \\
\text { (NP_012842) }\end{array}$ & Cytoplasm & $\begin{array}{l}\text { Elongation factor } 1- \\
\text { gamma }\end{array}$ & $\begin{array}{l}\text { Chain A, } \\
\text { 3- } \\
\text { Phosphog } \\
\text { lycerate } \\
\text { kinase, } \\
\text { mutation } \\
\text { R65q, } \\
\text { gi|157833 } \\
610(85)\end{array}$ \\
\hline 100 & $T K L 1$ & 73.8 & 6.48 & 680 & 194 & 11 & gi|3212468 & $\begin{array}{c}\text { 1AY0_A } \\
\text { (NP_015399) }\end{array}$ & Cytoplasm & Chain A, Transketolase. & $\begin{array}{c}\text { Conserve } \\
\text { d protein, } \\
\text { gi|151944 } \\
795 \text { (28) }\end{array}$ \\
\hline $141^{\prime}$ & UGP1 & 56.18 & 6.98 & 499 & 291 & 29 & gi|6322815 & NP_012889 & Cytoplasm & $\begin{array}{l}\text { UDP-glucose } \\
\text { pyrophosphorylase } \\
\text { (UGPase), catalyses the } \\
\text { reversible formation of } \\
\text { UDP-GIc from glucose 1- } \\
\text { phosphate and UTP, } \\
\text { involved in a wide variety } \\
\text { of metabolic pathways, } \\
\text { expression modulated by } \\
\text { Pho85p through Pho4p. }\end{array}$ & $\begin{array}{c}\text { Q0130, } \\
\text { gi|213322 } \\
4(35)\end{array}$ \\
\hline
\end{tabular}




\begin{tabular}{|c|c|c|c|c|c|c|c|c|c|c|c|}
\hline $\begin{array}{l}\text { Spot } \\
\text { No }\end{array}$ & $\begin{array}{l}\text { Gene } \\
\text { name }\end{array}$ & $\begin{array}{l}\text { Mass } \\
{[\mathrm{kDa}]}\end{array}$ & $\mathrm{p} /[\mathrm{pH}]$ & $\begin{array}{c}\text { Sequence } \\
\text { length } \\
{[\mathrm{AA}]}\end{array}$ & Score & $\begin{array}{c}\text { Sequence } \\
\text { Coverage } \\
{[\%]}\end{array}$ & GI No & $\begin{array}{c}\text { Accession No } \\
\text { [SwissProtKB/ } \\
\text { Swiss-Prot/ } \\
\text { S.cerevisiae] } \\
\text { (BLAST } \\
\text { Accession No) }\end{array}$ & $\begin{array}{l}\text { Subcellular } \\
\text { localization }\end{array}$ & Description & $\begin{array}{c}\text { Next } \\
\text { match, GI } \\
\text { no (score) }\end{array}$ \\
\hline $61^{\mathrm{DA}}$ & YNK1 & 17.21 & 8.65 & 153 & 250 & 44 & gi|6322783 & NP_012856 & $\begin{array}{c}\text { Cytoplasm } \\
\text { Mitochondrion } \\
\text { intermembrane } \\
\text { space }\end{array}$ & $\begin{array}{l}\text { Nucleoside diphosphate } \\
\text { kinase catalyzes the } \\
\text { transfer of gamma } \\
\text { phosphates from } \\
\text { nucleoside triphosphates, } \\
\text { usually ATP, to } \\
\text { nucleoside diphosphates } \\
\text { by a mechanism that } \\
\text { involves formation of an } \\
\text { autophosphorylated } \\
\text { enzyme intermediate. }\end{array}$ & $\begin{array}{c}\text { Rps17bp, } \\
\text { gi|632065 } \\
5 \text { (81) }\end{array}$ \\
\hline
\end{tabular}




\subsection{Gene ontology}

Analysis of the function of identified proteins was done using the Kyoto Encyclopedia of Genes and Genomes (KEGG). Proteins were searched against the S. cerevisiae reference database, and the results are shown in Figure 15 (refer to supplementary file 1 for additional information).

The majority of proteins that were identified were classified as being involved in metabolism. Thirty-eight proteins were classified as participating in secondary metabolism (Aat2, Ade13, Adh1, Adk1, Ald6, Aro8, Bat1, Cdc19, Eno1, Eno2, Erg10, Fba1, Glk1, Gnd1, Gpm1, Gus1, Hom2, Hxk2, Idh1, Idp1, Ilv3, Imd2, Imd4, Pdc1, Pfk2, Pgk1, Pmi40, Psa1, Sam1, Sec53, Shm1, Shm2, Tdh1, Tdh3, Tkl1, Tpi1, Ugp1 and Ynk1). "Carbohydrate metabolism" contained 27 proteins (Adh1, Ald6, Cdc19, Eno1, Eno2, Erg10, Fba1, Glk1, Gln1, Gnd1, Gpm1, Hxk2, Idh1, Idp1, Lys21, Pdc1, Pfk2, Pgk1, Pmi40, Psa1, Sec53, Shm1, Shm2, Tdh1, Tdh3, Tk11, Tpi1 and Ugp1), and included the subgroup "glycolysis/ gluconeogenesis" with 15 proteins (Adh1, Ald6, Cdc19, Eno1, Eno2, Fba1, Glk1, Gpm1, Hxk2, Pdc1, Pfk2, Pgk1, Tdh1, Tdh3 and Tpi1). Proteins involved in the central pathways of carbohydrate metabolism are shown in Table 7. Figure 16 shows the location of glycolytic enzymes on a 2DE gel. Some locations did not match the predicted Mr or $\mathrm{pI}$, most likely due to the presence of proteolytic fragments of posttranslational modifications.

“Energy metabolism" included 16 proteins (Atp1, Atp2, Atp3, Eno1, Eno2, Fba1, Gdh1, Gln1, Gpm1, Pfk2, Shm1, Shm2, Vma2, Vma4, Vma6 and Vma7). Nucleotide metabolism was represented by 8 proteins (Ade13, Adk1, Cdc19, Fur1, Gua1, Imd2, Imd4 and Ynk1). There were 21 proteins involved in amino acid metabolism (Aat2, Ade13, Adh1, Ald6, Aro8, Bat1, Cys3, Erg10, Gdh1, Gln1, Gnd1, Gpm1, Hom2, Idp1, Ilv3, Lys21, Sah1, Sam1, Shm1, Shm2 and Spe3). "Metabolism of cofactors and vitamins" included 6 proteins: Aro8, Bat1, Gus1, Ilv3, Shm1 and Shm2. Erg10 was the only protein involved in metabolism of terpenoids and polyketides.

Twenty-seven proteins were found to be involved in transcription/translation. Four proteins were involved in transcription (Dbp2, Ssa1, Ssa2 and Ssb2), twenty-three proteins were involved in translation (Dps1, Gus1, Rna1, Rpl11A, Rpl12B, Rpl13A, Rps0A, Rps12, Rps15, Rps19B, Rps20, Rps21A, Rps22A, Rps27A, Rps3, Rps4B, Rps5, 
Rps7A, Sup45, Tef2, Tif2, Tif6 and YHR020W). Sixteen proteins were involved in folding, sorting and degradation (Cdc48, Eno1, Eno2, Hsc82, Hsp60, Hsp82, Kar2, Pdi1, Ssa1, Ssa2, Ssb2, Ssc1, Sse1, Rpt5 and Rpt6). Twelve proteins were involved in transport and catabolism (Act1, Idp1, Sod1, Ssa1, Ssa2, Ssb2, Tub1, Tub2, Vma2, Vma4, Vma6 and Vma7). Thirty-four proteins were uncategorized: Abp1, Ade5, 7, Arc1, Bmh1, Bmh2, Cam1, Cct5, Cdc12, Cof1, Cpr1, Eft2, Eht1, Fpr1, Hri1, Hsp10, Hsp104, Htb2, Ola1, Oye2, Paa1, Phb2, Prb1, Pst2, Sis1, Srp1, Ssb1, Stm1, Tef4, Tfp1, Tma19, Tpm1, Tsa1, Wtm1 and Zeo1. 


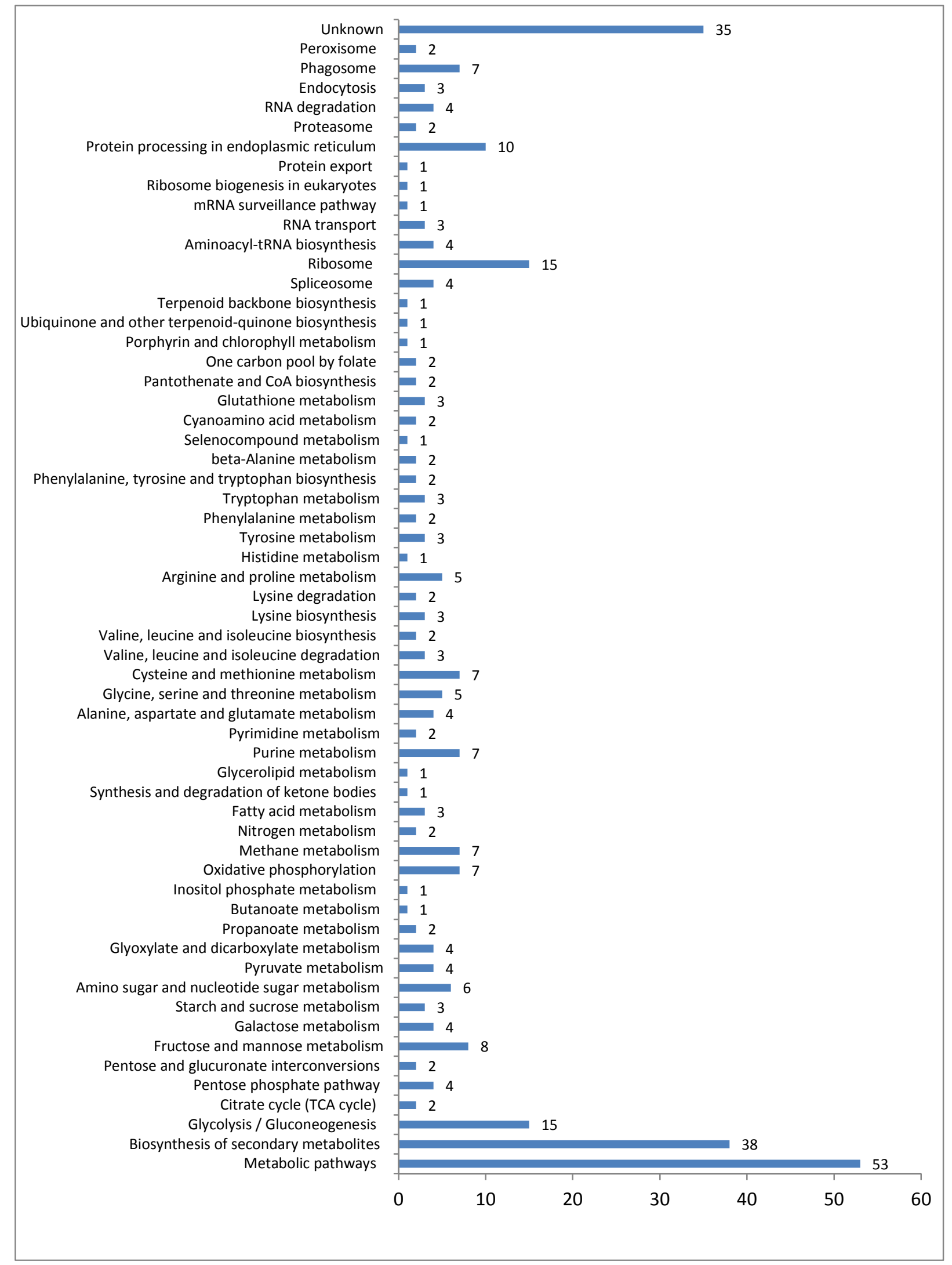

Figure 15 - Gene ontology annotations of the functions of protein identified from the reference protein maps (Figure 13 and Figure 14). The number of proteins listed is greater than the number identified due to multifunctional properties of some proteins. 
Table 7 - Identified proteins from the reference protein map (Table 5 and Table 6) that were involved in central carbohydrate metabolism (Figure 15).

\begin{tabular}{|c|c|c|}
\hline $\begin{array}{l}\text { Gene } \\
\text { name }\end{array}$ & Protein name & $\begin{array}{c}\text { Gel A (pH 4-7, Figure 13) or } \\
\text { gel B (pH 6-11, Figure 14) } \\
\text { [Spot number] }\end{array}$ \\
\hline \multicolumn{3}{|c|}{ Glycolysis/gluconeogenesis } \\
\hline$A D H 1$ & Alcohol dehydrogenase 1 & $\mathrm{~A}[9,10 \& 31]$ \\
\hline$A L D 6$ & Aldehyde dehydrogenase 6 & $A[201]$ \\
\hline CDC19 & Pyruvate kinase 19 & $\mathrm{~B}[46,72,119,120,130 \& 140]$ \\
\hline ENO1 & Enolase 1 & $\mathrm{~A}[15 \& 17]$ \\
\hline ENO2 & Enolase 2 & $\begin{array}{c}A[35,41,42,51,162 \& 224] \\
B[8]\end{array}$ \\
\hline FBA1 & Fructose-1,6-bisphosphate aldolase 1 & $A[120]$ \\
\hline GLK1 & Glucokinase 1 & $A[221]$ \\
\hline GPM1 & Phosphoglycerate mutase 1 & $\mathrm{~A}[65,70,71 \& 76]$ \\
\hline$H X K 2$ & Hexose kinase 2 & $A[82 \& 187]$ \\
\hline PDC1 & Pyruvate decarboxylase 1 & $A[27,215-219]$ \\
\hline PFK2 & Phosphofructokinase ( $\beta$ chain) & $A[200]$ \\
\hline PGK1 & 3-phosphoglycerate kinase & $\begin{array}{c}A[13] \\
B[64,124,145,147 \& 151]\end{array}$ \\
\hline$T D H 1$ & Glyceraldehyde-3-phosphate dehydrogenase 1 & $\mathrm{~B}[132]$ \\
\hline$T D H 3$ & Glyceraldehyde-3-phosphate dehydrogenase 3 & $\begin{array}{c}A[5] \\
B[43,128 \& 152]\end{array}$ \\
\hline TPI1 & Trisephosphate isomerase & $A[45]$ \\
\hline \multicolumn{3}{|c|}{ Citrate acid cycle (TCA cycle) } \\
\hline IDH1 & $\begin{array}{c}\text { Mitochondrial } \mathrm{NAD}^{+} \text {dependent isocitrate } \\
\text { dehydrogenase } 1\end{array}$ & $B[134]$ \\
\hline IDP1 & $\begin{array}{c}\text { Mitochondrial NADP specific isocitrate } \\
\text { dehydrogenase } 1\end{array}$ & $\mathrm{~B}[112]$ \\
\hline \multicolumn{3}{|c|}{ Pentose phosphate pathway } \\
\hline FBA1 & Fructose-1,6-bisphosphate aldolase 1 & $A[120]$ \\
\hline GND1 & 6-phosphoglycerate dehydrogenase 1 & $A[16]$ \\
\hline PFK2 & Phosphofructokinase ( $\beta$ chain) & $A[200]$ \\
\hline$T K L 1$ & Transketolase 1 & $\mathrm{~B}[100]$ \\
\hline
\end{tabular}



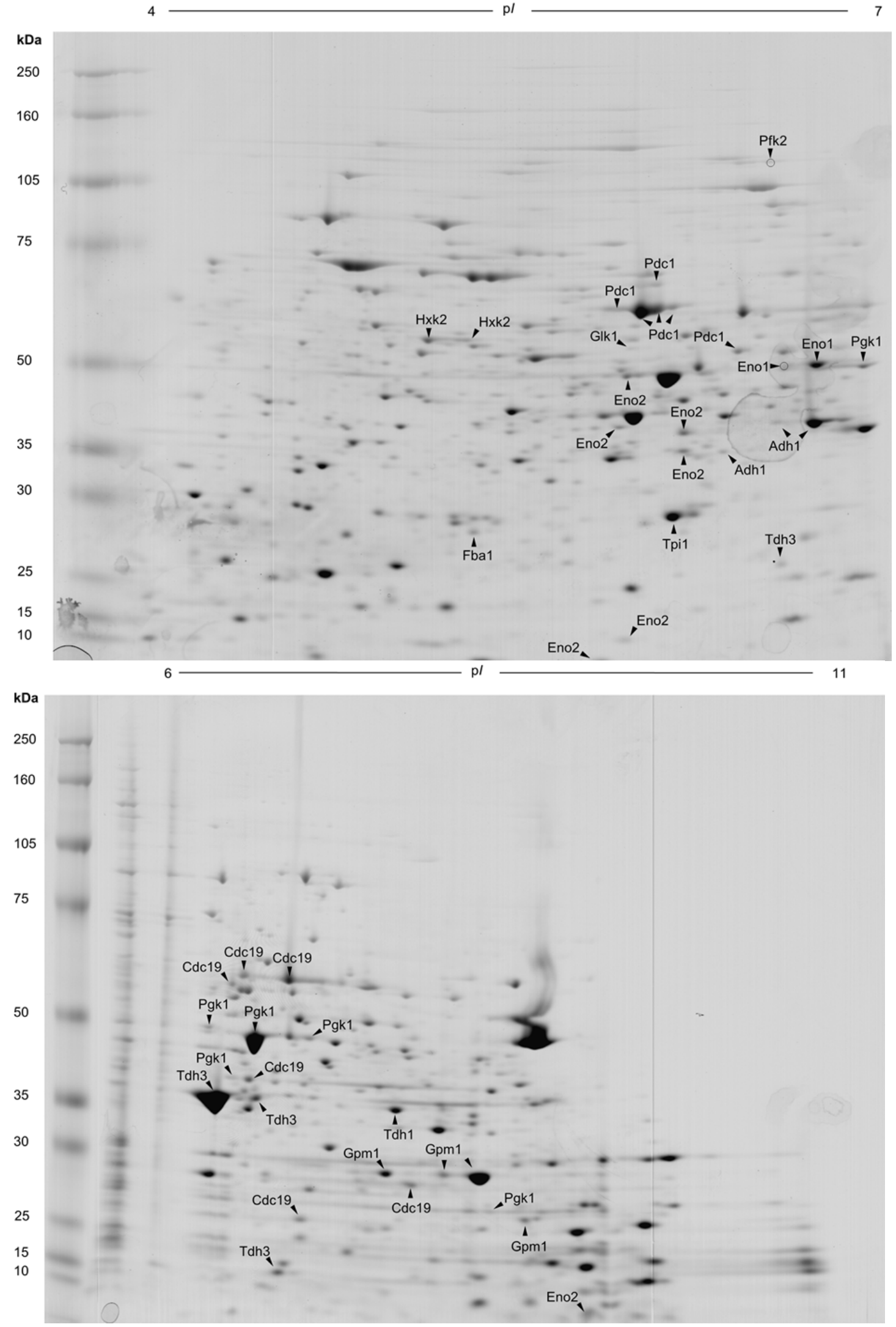

Figure 16 - Two-dimensional gel images of BY4741 proteins $(100 \mu \mathrm{g})$ separated on pH 4-7 (Figure 13, top) or pH 6-11 (Figure 14, bottom) IPG strips. The positions of glycolytic enzymes are shown. The ladder used for molecular weight reference was Rainbow 851. 


\subsection{Measurement of glucose use and ethanol production}

The aim of this set of experiments was to determine conditions for growth of

S. cerevisiae for 2D-DIGE comparative analysis of fermentative and non-fermentative growth. Two approaches were explored: using different glucose concentrations and use of glycerol as a carbon source.

Table 8 summarizes glucose consumption and ethanol production for cell cultures grown on $0.2-2 \%$ glucose (A), and growth on glucose or glycerol (B). Results include means and standard deviations for each $n=4$ experiment. The first experiment, examined the use of low $(0.2 \%)$, medium $(0.5 \%)$ or high $(2 \%)$ concentrations of glucose in SC media (Table 8A), and shows complete use of glucose at low and medium concentrations. Ethanol was only detected for cells grown at the high $(2 \%)$ glucose concentration indicating use of glucose in the alternative pathways at the lower $(0.2 \%, 0.5 \%)$ glucose concentrations. For the "high glucose" grown cells, glucose consumption was partial and the ratio of ethanol produced to glucose used was greater than expected for complete conversion of glucose to ethanol (2 ethanol per glucose). This suggested that other pathways may have contributed to ethanol production unless measurement errors were responsible for the $>2$ ratio.

In the second experiment, comparing growth on glycerol, ethanol was only produced when glucose was the substrate (Table 8B). Therefore, fermentative growth was indicated by high ethanol production in aerobic conditions, and consumption of glucose.

Table 8 - Glucose consumption and ethanol production of $0.2 \%$ (low), $0.5 \%$ (medium) and $2 \%$ (high) glucose grown yeast cells (A) and 3\% glycerol vs. $2 \%$ glucose grown cells (B). The second and third column displays the respective amount of glucose remaining and used. The last column represents the amount of ethanol produced in mmols as well as the ratio of glucose to ethanol used.

\begin{tabular}{|c|c|c|c|}
\hline Glucose \%(mmol) & $\begin{array}{l}\text { Glucose remaining } \\
\qquad(\mathrm{mmol})\end{array}$ & $\begin{array}{l}\text { Glucose used } \\
\quad(\mathrm{mmol})\end{array}$ & $\begin{array}{c}\text { Ethanol produced } \\
(\mathrm{mmol}) \\
\text { [ethanol/glucose] }\end{array}$ \\
\hline $0.2 \%(0.27)$ & 0 & 0.27 & 0 \\
\hline $0.5 \%(0.67)$ & 0 & 0.67 & 0 \\
\hline $2 \%(2.7)$ & $1.09 \pm 0.06$ & 1.61 & $6.9 \pm 0.44[2.56]$ \\
\hline
\end{tabular}


B

\begin{tabular}{|c|c|c|c|}
\hline $\begin{array}{c}\text { Glucose or glycerol } \\
\%(\mathrm{mmol})\end{array}$ & $\begin{array}{c}\text { Glucose remaining } \\
(\mathrm{mmol})\end{array}$ & $\begin{array}{c}\text { Glucose used } \\
(\mathrm{mmol})\end{array}$ & $\begin{array}{c}\text { Ethanol produced } \\
\text { (ethanol/glucose) }\end{array}$ \\
\hline $3 \%$ glycerol $(\mathrm{G} 1)$ & 0 & 0 & 0 \\
\hline $2 \%$ glucose $(2.7)$ & $1.29 \pm 0.11$ & 1.41 & $6.19 \pm 1.19[2.29]$ \\
\hline $3 \%$ glycerol $(\mathrm{G} 2)$ & 0 & 0 & 0 \\
\hline
\end{tabular}

\subsection{Comparative proteomics}

2D-DIGE was used to compare differences in protein abundances between fermentative and non-fermentative growth using cells grown on glucose or glycerol.

\subsubsection{Growth on glucose (D) or glycerol (G)}

A 2D-DIGE experiment was used to compare the differences between glycerol (G2) and glucose (D) grown cells using pH 3-11 non-linear (3-11NL) IPG strips. The 2DDIGE image showing the differences between glucose (red) and glycerol (blue) supplemented cells is shown in Figure 17. A total of 219 proteins changed greater than 2-fold at $\mathrm{p} \leq 0.01$ (refer to supplementary file 2). Of these, 99 protein spots had an average ratio greater than 2, indicative of greater protein abundance in glucose grown conditions. The majority of proteins specific to fermentative growth had a neutral or acidic $\mathrm{pI}$. The other 120 had an average ratio less than -2 , indicating greater protein abundance in glycerol grown conditions. A large group of basic protein spots were associated with cells grown on glycerol. Only a small number of these proteins were identified by excision of CBB G-250 stained spots off the 2DDIGE gels because of the small protein amounts used in DIGE analysis (indicated by a black arrow) (Table 8). The abundant proteins specific to glucose growth that were identified included Fba1, Eno2, Sec53, Ssa1/2, Sod1, Egd2, Crp1 and Fpr1 shown in Figure 17 and Table 9. Of note, several glycolysis/ gluconeogenesis proteins were found to be more abundant in glucose grown cultures (Fba1 and Eno2). 


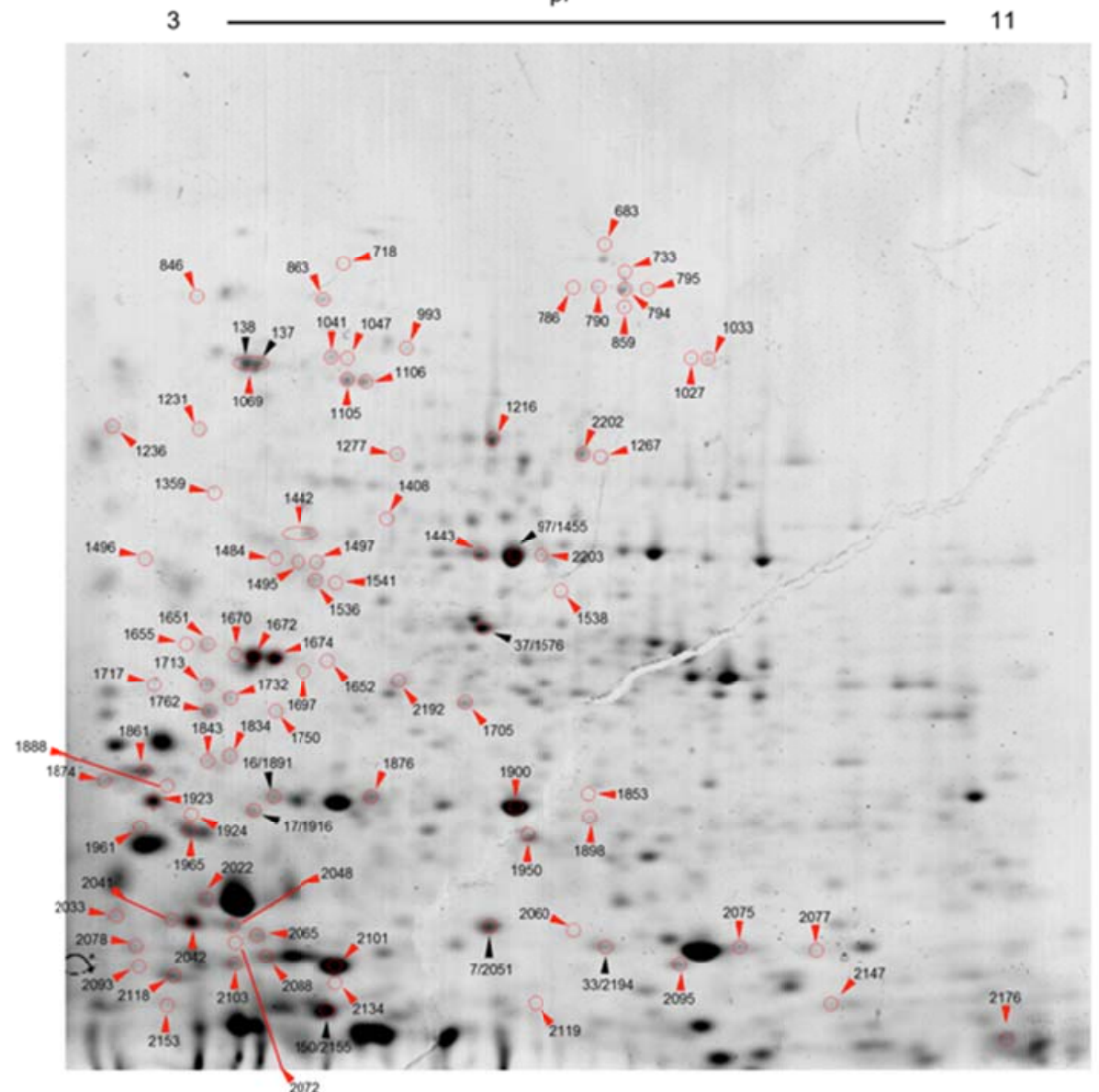

3

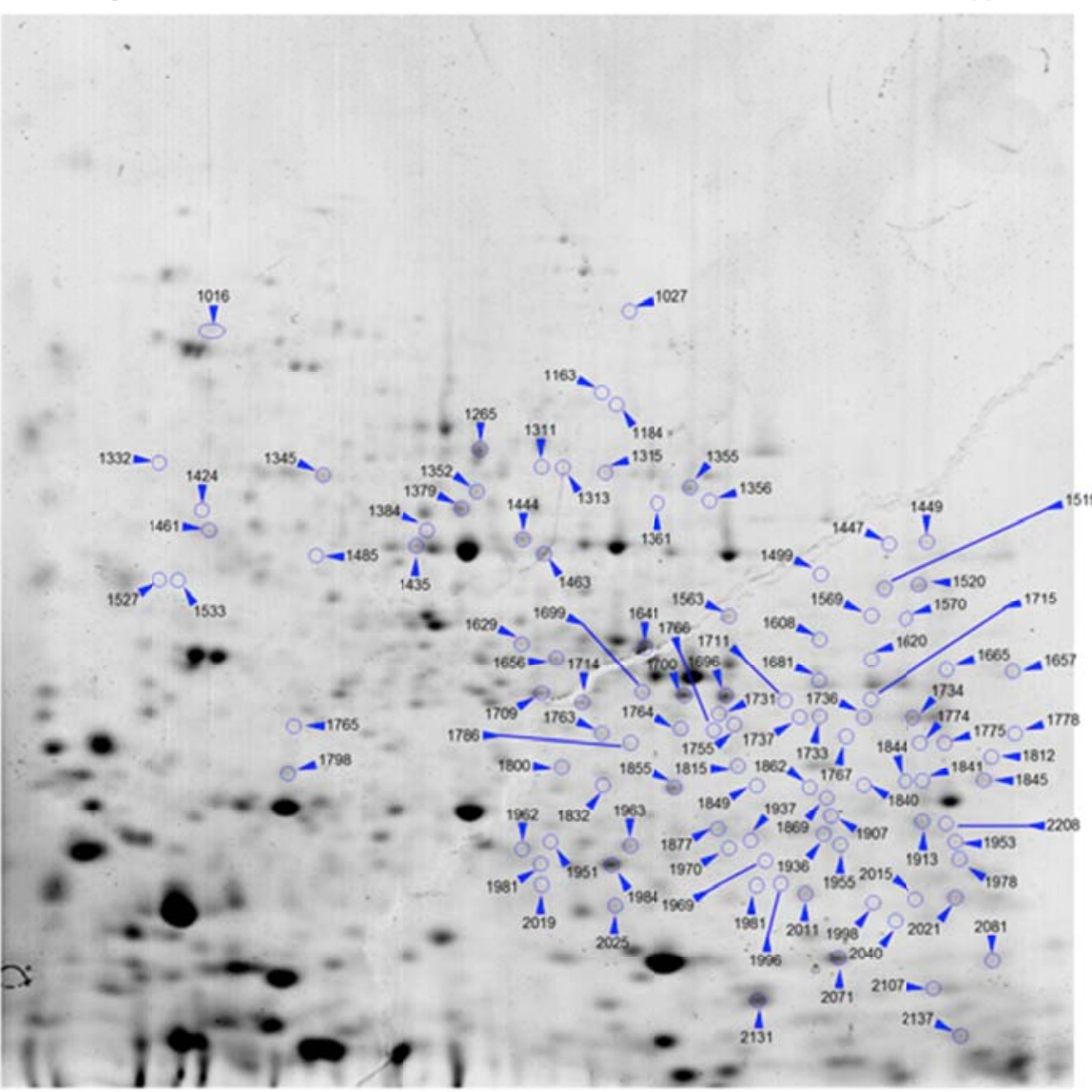

Figure 17 - Two-dimensional images of the DIGE experiment portraying the differences in protein abundance between BY4741 cells grown in glucose (red) and glycerol (blue). The DIGE experiment required fluorescent labeling of the cell cultures in $2 \%$ glucose or $3 \%$ glycerol with different dyes. The colored asterisks represent proteins that had a significant level of change $(\geq 2 X, p \leq 0.01)$. Proteins identified from the 2D-DIGE gels with a significant MASCOT score are marked with black asterisks. 
Table 9 lists proteins that were identified by excision of protein spots from 2D-DIGE gels. For each identified protein the DeCyder ${ }^{\mathrm{TM}}$ spot number is given, with the average ratio (fold change) between replicates, the Student's $t$-test value and the gene name. Proteins that were identified were specific to growth on glucose. No proteins specific to non-fermentative growth (3\% glycerol) were identified.

Table 9 - Proteins identified from the glucose versus glycerol grown DIGE experiment $(\mathrm{p} \leq 0.01)$. The data is sorted by the average ratio from lowest to highest fold ( $\geq 2$-fold) change. The average ratio is the value of change from condition 1 (glucose) in comparison to condition 2 (glycerol). A positive average ratio indicates an increase in protein abundance associated with growth on glucose.

\begin{tabular}{|c|c|c|c|c|}
\hline $\begin{array}{l}\text { Master No } \\
\text { (Spot No) }\end{array}$ & $\begin{array}{l}\text { Average } \\
\text { ratio }\end{array}$ & $t$-test & Protein name & $\begin{array}{l}\text { Gene } \\
\text { name }\end{array}$ \\
\hline $1891(16)$ & 2.04 & 0.008 & Phosphomannomutase & SEC53 \\
\hline $1576(37)$ & 3 & 0.0037 & $\begin{array}{c}\text { Fructose-1,6- } \\
\text { bisphosphate aldolase }\end{array}$ & FBA1 \\
\hline $\begin{array}{c}1069 \\
(137 / 138)\end{array}$ & 3.3 & 0.0046 & $\begin{array}{l}\text { Stress-seventy } \\
\text { subfamily A }\end{array}$ & SSA1/2 \\
\hline $2051(7)$ & 4.1 & 0.0012 & Superoxide dismutase & SOD1 \\
\hline $1916(17)$ & 4.28 & 0.0046 & $\begin{array}{l}\text { Enhancer of Gal4 DNA } \\
\text { binding }\end{array}$ & EGD2 \\
\hline 2194 (33) & 6.04 & 0.0045 & $\begin{array}{l}\text { Cyclosporin A- } \\
\text { sensitive proline } \\
\text { rotamase }\end{array}$ & CPR1 \\
\hline $1455(97)$ & 6.55 & 0.00021 & Enolase & ENO2 \\
\hline $\begin{array}{l}2155 \\
(150)\end{array}$ & 7.2 & 4.10E-05 & $\begin{array}{l}\text { Fk 506-senstive } \\
\text { proline rotamase }\end{array}$ & FPR1 \\
\hline
\end{tabular}

Subsequently, attempts were made to identify proteins that changed in abundance by matching proteins in the glucose vs. glycerol DIGE experiment (Figure 17) to the reference gels (Figure 13, Figure 14) using 'landmark patterns' on all gels. These proteins are listed in Table 10, and are possible matches only. Eighteen proteins were matched. 
Table 10 - Possible protein identifications for the glucose vs. glycerol DIGE experiment. The reference $\mathrm{pH} 4-7$ (Figure 13) and 6-11 (Figure 14) gels were used to match spots DeCyder ${ }^{\mathrm{TM}}$ assigned to the glucose versus glycerol 2D-DIGE gel (Figure 17).

\begin{tabular}{|c|c|c|c|c|}
\hline & Master spot No. & $\begin{array}{l}\text { Possible spot } \\
\text { match }\end{array}$ & Protein name & Gene name \\
\hline \multirow{18}{*}{ 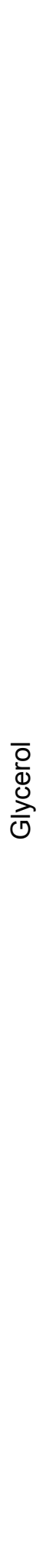 } & 846 & 177 & Actin binding protein 1 & $A B P 1$ \\
\hline & 1762 & 128 & $\begin{array}{l}\text { Brain modulosignalin } \\
\text { homologue } 1\end{array}$ & $B M H 1$ \\
\hline & 1713 & 127 & $\begin{array}{l}\text { Brain modulosignalin } \\
\text { homologue } 2\end{array}$ & $B M H 2$ \\
\hline & 1408 & 77 & $\begin{array}{c}\text { Glutamate } \\
\text { dehydrogenase }\end{array}$ & GDH1 \\
\hline & 1267 & 24 & Guanine auxotroph 1 & GUA1 \\
\hline & 1216 & 217 & $\begin{array}{c}\text { Pyruvate } \\
\text { dehydrogenase }\end{array}$ & $P D C 1$ \\
\hline & 683 & 200 & Phosphofrucotokinase & PFK2 \\
\hline & 1538 & 30 & $\begin{array}{l}\text { GDP-mannose } \\
\text { pyrophosphorylase }\end{array}$ & PSA1 \\
\hline & 1843 & 139 & $\begin{array}{c}\text { 40S ribosomal protein } \\
\text { SO-A }\end{array}$ & RPSOA \\
\hline & 2042 & 104 & $\begin{array}{c}\text { 40S ribosomal protein } \\
\text { S12 }\end{array}$ & RPS12 \\
\hline & 1231 & 93 & Importin subunit alpha & SRP1 \\
\hline & 1047 & 189 & $\begin{array}{l}\text { Heat shock protein } \\
\text { homolog SSC1 }\end{array}$ & SSC1 \\
\hline & 863 & 191 & $\begin{array}{l}\text { Heat shock protein } \\
\text { homolog SSE1 }\end{array}$ & SSE1 \\
\hline & 1484 & 147 & $\begin{array}{l}\text { Translation initiation } \\
\text { factor } 2\end{array}$ & TIF2 \\
\hline & 1923 & 131 & $\begin{array}{l}\text { Translation initiation } \\
\text { factor } 6\end{array}$ & TIF6 \\
\hline & 1900 & 45 & $\begin{array}{l}\text { Triosephosphate } \\
\text { isomerase }\end{array}$ & TPI1 \\
\hline & 1027 & 20 & $\begin{array}{l}\text { Arginyl-tRNA } \\
\text { synthase }\end{array}$ & YDR341C \\
\hline & 2101 & 99 & $\begin{array}{l}\text { Zeocin resistance } \\
\text { protein }\end{array}$ & ZEO1 \\
\hline
\end{tabular}


Figure 18 shows the GO annotations between the reference protein map and the proteins identified in the glucose versus glycerol DIGE experiment (refer to supplementary file 3 for additional information). The GO analysis of the glucose vs. glycerol 2D-DIGE experiment reflect a similar pattern, at a smaller scale, of functional groups compared to the $\mathrm{GO}$ annotations of the reference protein map. Carbohydrate metabolism is the largest category in both experiments. Figure 19 shows proteins involved in ethanol synthesis that were identified from the reference gels (red box) (Figure 13, Figure 14, Table 5 and Table 6) or changed in protein abundance between cells grown on glucose $\left(\mathrm{D}^{+}\right)$or glycerol $\left(\mathrm{G}^{+}\right)$. Only four of the 11 proteins involved in ethanol synthesis were identified in the 2D-DIGE experiment between cells grown in glucose or glycerol. 


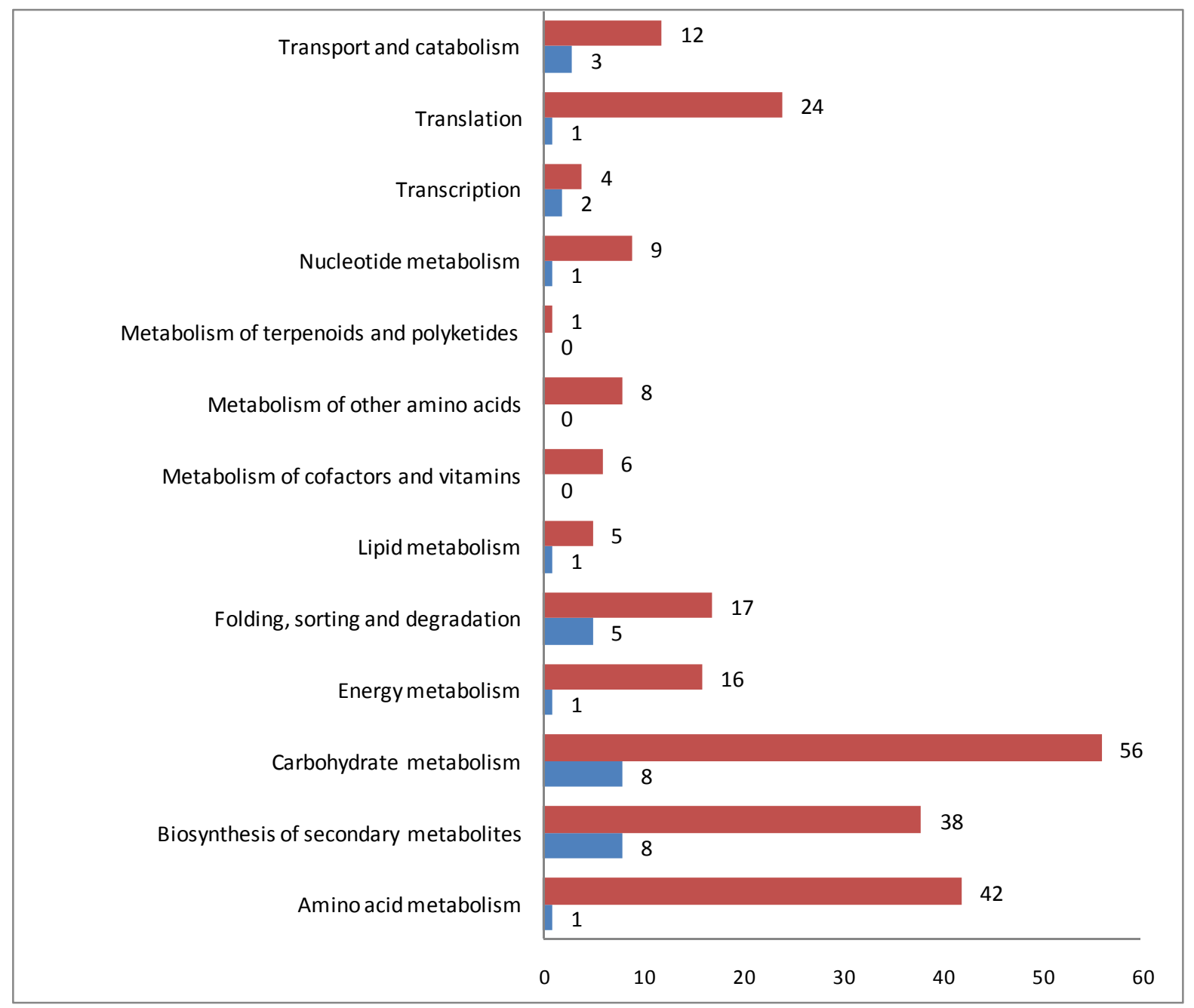

Figure 18 - Comparative gene ontology annotations of the functions between proteins identified for the reference protein map (red) and proteins identified from the glucose vs. glycerol DIGE experiment (blue). The number of proteins listed is greater than the number identified due to multifunctional properties of some proteins. 


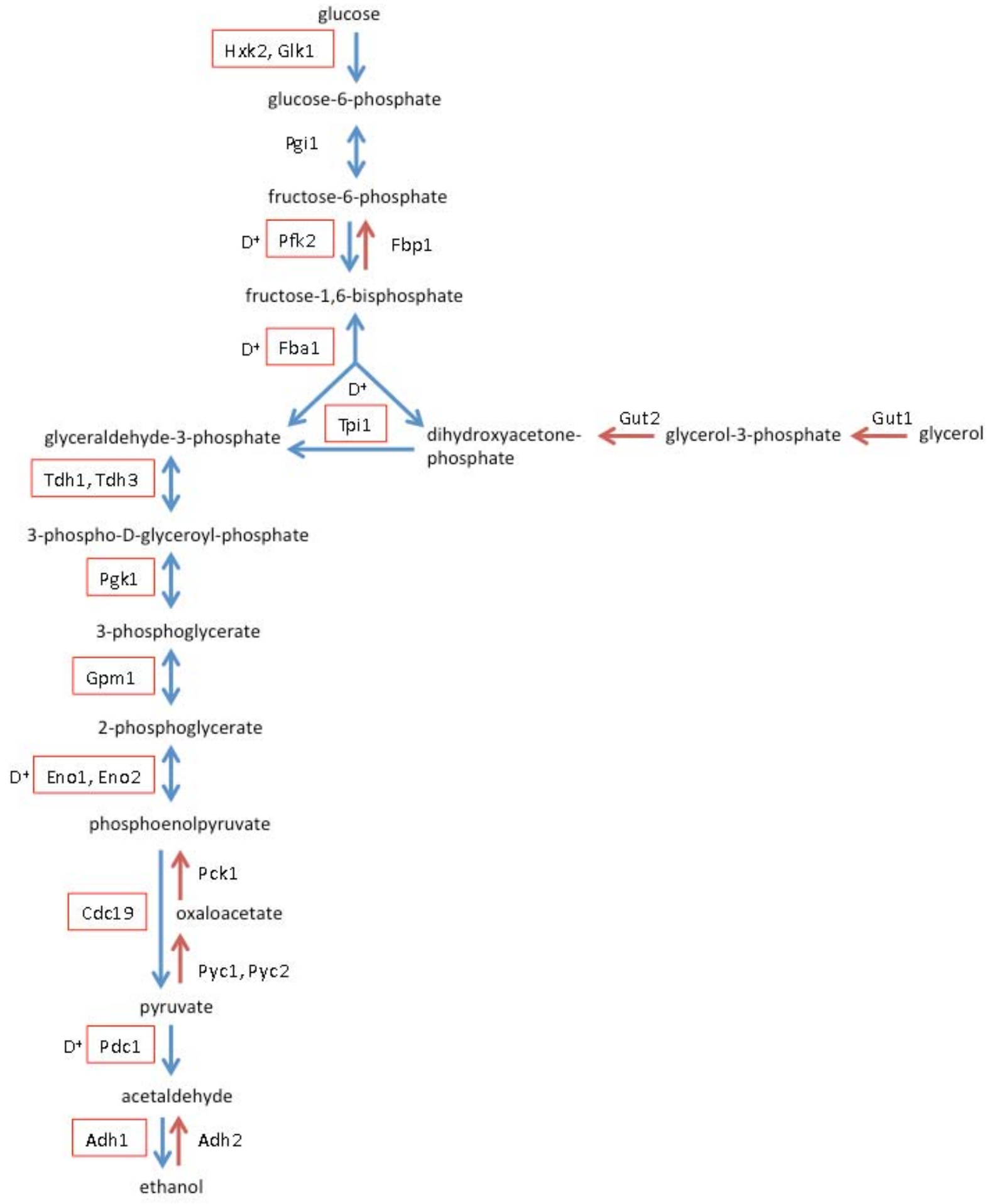

Figure 19 - Identified proteins (red box) involved in glucose and glycerol metabolism. The diagram also shows identified proteins that changed in glycerol $\left(\mathrm{G}^{+}\right)$or glucose $(\mathrm{D}+)$ conditions. 
Proteins that were matched by comparison with the reference gels (Figure 13, Figure 14). Proteins that were tentatively identified, not all of which were subject to specific growth conditions are shown in Figure 20 and Table 11. Twenty-seven protein spots were identified that corresponded to 20 unique protein identifications. Six glycolytic proteins were identified (Cdc19, Eno1, Eno2, Fba1, Pgk1 and Tpi1) as well as the fermentative enzyme Adh4. Adh2 and its transcriptional regulator Adr1 were detected, however they had Mascot scores $\leq 56$ with low confidence intervals.

\section{3}

$\mathrm{p} /$

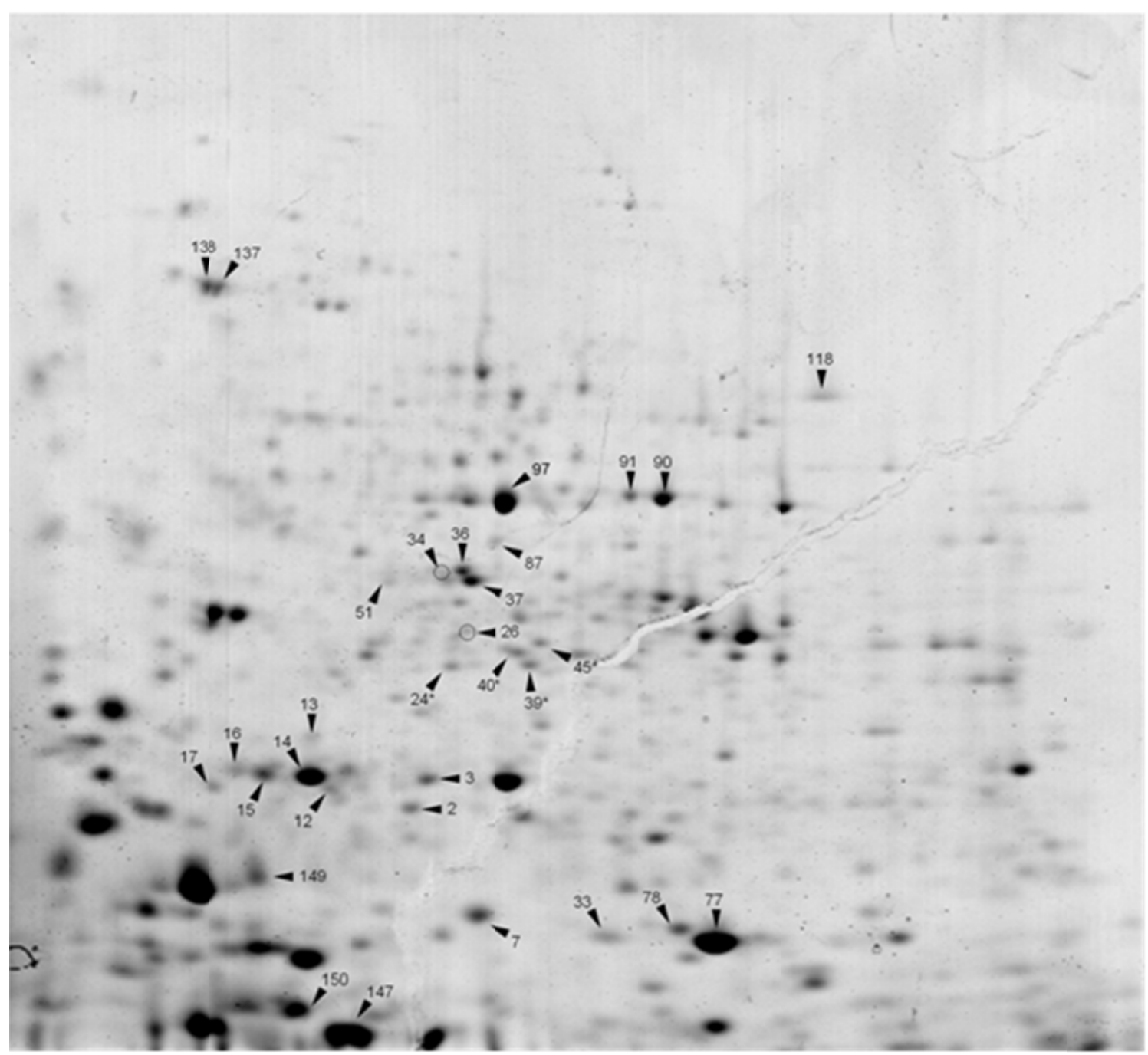

Figure 20 - Coomassie stained 2D-DIGE gel of the glucose vs. glycerol experiment. Proteins $(30 \mu \mathrm{g})$, which were identified by MALDI MS, are shown in Table 11. Four proteins $(24,39,40,45)$ had MASCOT scores less than 56 with low confidence interval. 
Table 11 - Proteins identified from the simplified glucose vs. glycerol grown DIGE experiment. Proteins (30 $\mu \mathrm{g})$ were separated on pH 3 11 NL IPG strips and identified using MALDI TOF/TOF. Proteins (score $\geq 56, p \leq 0.05$ ) are sorted alphabetically by their gene name.

The score and sequence coverage (\%) values are representative of the significance of the match generated by the MASCOT search. The calculated mass, pI, GI, accession number and description of the protein are gathered from the NCBI protein website. The subcellular localization of the protein was from UniProt. The next matched protein was the next non-homologous protein match.

\begin{tabular}{|c|c|c|c|c|c|c|c|c|c|c|c|}
\hline $\begin{array}{l}\text { Spot } \\
\text { No }\end{array}$ & $\begin{array}{l}\text { Gene } \\
\text { name }\end{array}$ & $\begin{array}{l}\text { Mass } \\
{[\mathrm{kDa}]}\end{array}$ & $\mathrm{p} /[\mathrm{pH}]$ & $\begin{array}{c}\text { Sequence } \\
\text { length } \\
{[\mathrm{AA}]}\end{array}$ & Score & $\begin{array}{c}\text { Sequence } \\
\text { Coverage } \\
{[\%]}\end{array}$ & GI No & $\begin{array}{c}\text { Accession No } \\
\text { [SwissProtKB/S } \\
\text { wiss-Prot/ } \\
\text { S.cerevisiae] } \\
\text { (BLAST } \\
\text { Accession No) }\end{array}$ & $\begin{array}{l}\text { Subcellular } \\
\text { localization }\end{array}$ & Description & $\begin{array}{c}\text { Next } \\
\text { match, GI } \\
\text { no (score) }\end{array}$ \\
\hline $24^{*}$ & $A D H 2$ & 37.17 & 6.26 & 348 & 20 & 20 & gi|6323961 & NP_014032 & Cytoplasm & $\begin{array}{l}\text { Glucose-repressible } \\
\text { alcohol dehydrogenase } \\
\text { II, catalyzes the } \\
\text { conversion of ethanol to } \\
\text { acetaldehyde; involved } \\
\text { in the production of } \\
\text { certain regulated by } \\
\text { ADR1. }\end{array}$ & None \\
\hline $40^{*}$ & $A D H 2$ & 37.17 & 6.26 & 348 & 36 & 36 & gi|6323961 & NP_014032 & Cytoplasm & $\begin{array}{l}\text { Glucose-repressible } \\
\text { alcohol dehydrogenase } \\
\text { II, catalyzes the } \\
\text { conversion of ethanol to } \\
\text { acetaldehyde; involved } \\
\text { in the production of } \\
\text { certain regulated by } \\
\text { ADR1. }\end{array}$ & None \\
\hline 36 & $A D H 4$ & 41.46 & 5.76 & 382 & 88 & 32 & gi|205831682 & $\begin{array}{c}\text { P10127 } \\
\text { (NP_011258) }\end{array}$ & Mitochondrion & $\begin{array}{l}\text { Alcohol dehydrogenase } \\
4\end{array}$ & $(-)$ \\
\hline
\end{tabular}




\begin{tabular}{|c|c|c|c|c|c|c|c|c|c|c|c|}
\hline $\begin{array}{l}\text { Spot } \\
\text { No }\end{array}$ & $\begin{array}{l}\text { Gene } \\
\text { name }\end{array}$ & $\begin{array}{l}\text { Mass } \\
{[\mathrm{kDa}]}\end{array}$ & $\mathrm{p} /[\mathrm{pH}]$ & $\begin{array}{c}\text { Sequence } \\
\text { length } \\
{[A A]}\end{array}$ & Score & $\begin{array}{c}\text { Sequence } \\
\text { Coverage } \\
{[\%]}\end{array}$ & GI No & $\begin{array}{c}\text { Accession No } \\
\text { [SwissProtKB/S } \\
\text { wiss-Prot/ } \\
\text { S.cerevisiae] } \\
\text { (BLAST } \\
\text { Accession No) }\end{array}$ & $\begin{array}{l}\text { Subcellular } \\
\text { localization }\end{array}$ & Description & $\begin{array}{c}\text { Next } \\
\text { match, GI } \\
\text { no (score) }\end{array}$ \\
\hline 34 & $A D H 4$ & 41.46 & 5.76 & 382 & 56 & 30 & gi|205831682 & $\begin{array}{c}\text { P10127 } \\
\text { (NP_011258) }\end{array}$ & Mitochondrion & $\begin{array}{c}\text { Alcohol dehydrogenase } \\
4\end{array}$ & $(-)$ \\
\hline $39^{*}$ & $A D R 1$ & 15.72 & 6.27 & 139 & 20 & 20 & gi|197253860 & $\begin{array}{c}\text { ACH54265 } \\
\text { (NP_010502) }\end{array}$ & Nucleus & $\begin{array}{l}\text { Carbon source- } \\
\text { responsive zinc-finger } \\
\text { transcription factor, } \\
\text { required for transcription } \\
\text { of the glucose- } \\
\text { repressed gene ADH2, } \\
\text { of peroxisomal protein } \\
\text { genes, and of genes } \\
\text { required for ethanol, } \\
\text { glycerol, and fatty acid } \\
\text { utilization. }\end{array}$ & None \\
\hline $45^{\star}$ & $A D R 1$ & 15.72 & 6.27 & 139 & 22 & 22 & gi|197253860 & $\begin{array}{l}\text { ACH54265 } \\
\text { (NP_010502) }\end{array}$ & Nucleus & $\begin{array}{l}\text { Carbon source- } \\
\text { responsive zinc-finger } \\
\text { transcription factor, } \\
\text { required for transcription } \\
\text { of the glucose- } \\
\text { repressed gene ADH2, } \\
\text { of peroxisomal protein } \\
\text { genes, and of genes } \\
\text { required for ethanol, } \\
\text { glycerol, and fatty acid } \\
\text { utilization }\end{array}$ & None \\
\hline
\end{tabular}




\begin{tabular}{|c|c|c|c|c|c|c|c|c|c|c|c|}
\hline $\begin{array}{l}\text { Spot } \\
\text { No }\end{array}$ & $\begin{array}{l}\text { Gene } \\
\text { name }\end{array}$ & $\begin{array}{l}\text { Mass } \\
{[\mathrm{kDa}]}\end{array}$ & $\mathrm{p} /[\mathrm{pH}]$ & $\begin{array}{c}\text { Sequence } \\
\text { length } \\
{[A A]}\end{array}$ & Score & $\begin{array}{c}\text { Sequence } \\
\text { Coverage } \\
{[\%]}\end{array}$ & GI No & $\begin{array}{c}\text { Accession No } \\
\text { [SwissProtKB/S } \\
\text { wiss-Prot/ } \\
\text { S.cerevisiae] } \\
\text { (BLAST } \\
\text { Accession No) }\end{array}$ & $\begin{array}{l}\text { Subcellular } \\
\text { localization }\end{array}$ & Description & $\begin{array}{c}\text { Next } \\
\text { match, GI } \\
\text { no (score) }\end{array}$ \\
\hline 118 & $\begin{array}{c}C D C 1 \\
9\end{array}$ & 54.91 & 7.56 & 500 & 73 & 24 & gi|6319279 & NP_009362 & Cytoplasm & $\begin{array}{l}\text { Pyruvate kinase, } \\
\text { functions as a } \\
\text { homotetramer in } \\
\text { glycolysis to convert } \\
\text { phosphoenolpyruvate to } \\
\text { pyruvate, the input for } \\
\text { aerobic (TCA cycle) or } \\
\text { anaerobic (glucose } \\
\text { fermentation) } \\
\text { respiration. }\end{array}$ & $\begin{array}{c}\text { Fat1p } \\
\text { partial, } \\
\text { AAP21758 } \\
(19)\end{array}$ \\
\hline 77 & CPR1 & 17.49 & 6.90 & 162 & 103 & 50 & gi|6320359 & NP_010439 & Cytoplasm & $\begin{array}{l}\text { Cytoplasmic peptidyl- } \\
\text { prolylcis-trans } \\
\text { isomerase (cyclophilin), } \\
\text { catalyzes the cis-trans } \\
\text { isomerization of peptide } \\
\text { bonds N-terminal to } \\
\text { proline residues; binds } \\
\text { the drug cyclosporin A. }\end{array}$ & $\begin{array}{c}\text { unnamed } \\
\text { protein } \\
\text { product, } \\
\text { CAA25036 } \\
(30)\end{array}$ \\
\hline 33 & CPR1 & 17.49 & 6.90 & 162 & 66 & 54 & gi|6320359 & NP_010439 & Cytoplasm & $\begin{array}{l}\text { Cytoplasmic peptidyl- } \\
\text { prolylcis-trans } \\
\text { isomerase (cyclophilin), } \\
\text { catalyzes the cis-trans } \\
\text { isomerization of peptide } \\
\text { bonds N-terminal to } \\
\text { proline residues; binds } \\
\text { the drug cyclosporin A. }\end{array}$ & $\begin{array}{c}\text { Tom5p, } \\
\text { NP_015459 } \\
\text { (23) }\end{array}$ \\
\hline
\end{tabular}




\begin{tabular}{|c|c|c|c|c|c|c|c|c|c|c|c|}
\hline $\begin{array}{l}\text { Spot } \\
\text { No }\end{array}$ & $\begin{array}{l}\text { Gene } \\
\text { name }\end{array}$ & $\begin{array}{l}\text { Mass } \\
{[\mathrm{kDa}]}\end{array}$ & $\mathrm{p} /[\mathrm{pH}]$ & $\begin{array}{l}\text { Sequence } \\
\text { length } \\
{[\mathrm{AA}]}\end{array}$ & Score & $\begin{array}{c}\text { Sequence } \\
\text { Coverage } \\
{[\%]}\end{array}$ & GI No & $\begin{array}{c}\text { Accession No } \\
\text { [SwissProtKB/S } \\
\text { wiss-Prot/ } \\
\text { S.cerevisiae] } \\
\text { (BLAST } \\
\text { Accession No) }\end{array}$ & $\begin{array}{l}\text { Subcellular } \\
\text { localization }\end{array}$ & Description & $\begin{array}{l}\text { Next } \\
\text { match, GI } \\
\text { no (score) }\end{array}$ \\
\hline 78 & CPR3 & 20.02 & 8.81 & 182 & 71 & 44 & gi|6323562 & NP_013633 & $\begin{array}{l}\text { Mitochondrion } \\
\text { matrix }\end{array}$ & $\begin{array}{l}\text { Mitochondrial peptidyl- } \\
\text { prolylcis-trans } \\
\text { isomerase } \\
\text { (cyclophilin),catalyzes } \\
\text { the cis-trans } \\
\text { isomerization of peptide } \\
\text { bonds N-terminal to } \\
\text { proline residues; } \\
\text { involved in protein } \\
\text { refolding after import } \\
\text { into mitochondria. }\end{array}$ & $\begin{array}{c}\text { unnamed } \\
\text { protein } \\
\text { product } \\
\text { partial, } \\
\text { CAA97190 } \\
\text { (30) }\end{array}$ \\
\hline 17 & EGD2 & 18.30 & 4.84 & 170 & 95 & 57 & gi|172043 & $\begin{array}{l}\text { AAC15849 } \\
\text { (NP_012063) }\end{array}$ & $\begin{array}{l}\text { Cytoplasm } \\
\text { Nucleus }\end{array}$ & $\begin{array}{l}\text { Egd2p (Enhancer of } \\
\text { GAL4 DNA binding). }\end{array}$ & $\begin{array}{c}\text { Chain B, } \\
\text { Ribosomal } \\
\text { 80s-Eef2- } \\
\text { Sordarin } \\
\text { Complex, } \\
\text { 1S1H_B } \\
(25)\end{array}$ \\
\hline 90 & ENO1 & 46.66 & 6.04 & 436 & 105 & 36 & gi|157830958 & $\begin{array}{c}\text { 1ELS_A } \\
\left(\mathrm{NP} \_011770\right)\end{array}$ & Cytoplasm & $\begin{array}{c}\text { Chain A, Enolase-Mn2+- } \\
\text { Phosphonoacetohydrox } \\
\text { amate }\end{array}$ & $(-)$ \\
\hline 91 & ENO1 & 46.68 & 6.17 & 436 & 67 & 31 & gi|20151217 & $\begin{array}{c}\text { 1L8P_A } \\
\left(\mathrm{NP} \_011770\right)\end{array}$ & Cytoplasm & $\begin{array}{c}\text { Chain A, Mg- } \\
\text { Phosphonoacetohydrox } \\
\text { amate Complex Of S39a } \\
\text { Yeast Enolase } 1\end{array}$ & $\begin{array}{l}\text { Ups3p, } \\
\text { NP_010471 } \\
\text { (27) }\end{array}$ \\
\hline
\end{tabular}

స్త్ర 


\begin{tabular}{|c|c|c|c|c|c|c|c|c|c|c|c|}
\hline $\begin{array}{l}\text { Spot } \\
\text { No }\end{array}$ & $\begin{array}{l}\text { Gene } \\
\text { name }\end{array}$ & $\begin{array}{l}\text { Mass } \\
{[\mathrm{kDa}]}\end{array}$ & $\mathrm{p} /[\mathrm{pH}]$ & $\begin{array}{c}\text { Sequence } \\
\text { length } \\
{[A A]}\end{array}$ & Score & $\begin{array}{c}\text { Sequence } \\
\text { Coverage } \\
{[\%]}\end{array}$ & GI No & $\begin{array}{c}\text { Accession No } \\
\text { [SwissProtKB/S } \\
\text { wiss-Prot/ } \\
\text { S.cerevisiae] } \\
\text { (BLAST } \\
\text { Accession No) }\end{array}$ & $\begin{array}{l}\text { Subcellular } \\
\text { localization }\end{array}$ & Description & $\begin{array}{c}\text { Next } \\
\text { match, GI } \\
\text { no (score) }\end{array}$ \\
\hline 97 & ENO2 & 46.94 & 5.67 & 437 & 100 & 36 & gi|6321968 & NP_012044 & Cytoplasm & $\begin{array}{c}\text { Enolase II, a } \\
\text { phosphopyruvate } \\
\text { hydratase that catalyzes } \\
\text { the conversion of 2- } \\
\text { phosphoglycerate to } \\
\text { phosphoenolpyruvate } \\
\text { during glycolysis and the } \\
\text { reverse reaction during } \\
\text { gluconeogenesis; } \\
\text { expression is induced in } \\
\text { response to glucose. }\end{array}$ & $\begin{array}{c}\text { YGR254W } \\
\text { p-like } \\
\text { protein, } \\
\text { EDZ71898 } \\
(42)\end{array}$ \\
\hline 26 & ENO2 & 46.94 & 5.67 & 437 & 56 & 25 & gi|6321968 & NP_012044 & Cytoplasm & $\begin{array}{c}\text { Enolase II, a } \\
\text { phosphopyruvate } \\
\text { hydratase that catalyzes } \\
\text { the conversion of 2- } \\
\text { phosphoglycerate to } \\
\text { phosphoenolpyruvate } \\
\text { during glycolysis and the } \\
\text { reverse reaction during } \\
\text { gluconeogenesis; } \\
\text { expression is induced in } \\
\text { response to glucose. }\end{array}$ & $(-)$ \\
\hline
\end{tabular}




\begin{tabular}{|c|c|c|c|c|c|c|c|c|c|c|c|}
\hline $\begin{array}{l}\text { Spot } \\
\text { No }\end{array}$ & $\begin{array}{l}\text { Gene } \\
\text { name }\end{array}$ & $\begin{array}{l}\text { Mass } \\
{[\mathrm{kDa}]}\end{array}$ & $\mathrm{p} /[\mathrm{pH}]$ & $\begin{array}{c}\text { Sequence } \\
\text { length } \\
{[A A]}\end{array}$ & Score & $\begin{array}{c}\text { Sequence } \\
\text { Coverage } \\
{[\%]}\end{array}$ & GI No & $\begin{array}{c}\text { Accession No } \\
\text { [SwissProtKB/S } \\
\text { wiss-Prot/ } \\
\text { S.cerevisiae] } \\
\text { (BLAST } \\
\text { Accession No) }\end{array}$ & $\begin{array}{l}\text { Subcellular } \\
\text { localization }\end{array}$ & Description & $\begin{array}{c}\text { Next } \\
\text { match, GI } \\
\text { no (score) }\end{array}$ \\
\hline 37 & $F B A 1$ & 39.88 & 5.51 & 359 & 130 & 40 & gil6322790 & NP_012863 & $\begin{array}{l}\text { Cytoplasm } \\
\text { Mitochondrion }\end{array}$ & $\begin{array}{l}\text { Fructose-1,6- } \\
\text { bisphosphate aldolase } \\
\text { required for glycolysis } \\
\text { and gluconeogenesis; } \\
\text { catalyzes conversion of } \\
\text { fructose-1, } 6 \\
\text { bisphosphate to } \\
\text { glyceraldehyde-3-P and } \\
\text { dihydroxyacetone-P; } \\
\text { locates to mitochondrial } \\
\text { outer surface upon } \\
\text { oxidative stress. }\end{array}$ & $\begin{array}{c}\text { Glo4p, } \\
\text { NP_014683 } \\
\text { (22) }\end{array}$ \\
\hline 12 & $F B A 1$ & 39.88 & 5.51 & 359 & 92 & 30 & gil 6322790 & NP_012863 & $\begin{array}{l}\text { Cytoplasm } \\
\text { Mitochondrion }\end{array}$ & $\begin{array}{c}\text { Fructose } 1,6- \\
\text { bisphosphate aldolase } \\
\text { required for glycolysis } \\
\text { and gluconeogenesis; } \\
\text { catalyzes conversion of } \\
\text { fructose } 1,6 \\
\text { bisphosphate to } \\
\text { glyceraldehyde-3-P and } \\
\text { dihydroxyacetone-P; } \\
\text { locates to mitochondrial } \\
\text { outer surface upon } \\
\text { oxidative stress. }\end{array}$ & $\begin{array}{c}\text { Hsp26p, } \\
\text { NP_009628 } \\
\text { (68) }\end{array}$ \\
\hline
\end{tabular}


స్

\begin{tabular}{|c|c|c|c|c|c|c|c|c|c|c|c|}
\hline $\begin{array}{l}\text { Spot } \\
\text { No }\end{array}$ & $\begin{array}{l}\text { Gene } \\
\text { name }\end{array}$ & $\begin{array}{l}\text { Mass } \\
{[\mathrm{kDa}]}\end{array}$ & $\mathrm{p} /[\mathrm{pH}]$ & $\begin{array}{c}\text { Sequence } \\
\text { length } \\
{[A A]}\end{array}$ & Score & $\begin{array}{c}\text { Sequence } \\
\text { Coverage } \\
{[\%]}\end{array}$ & GI No & $\begin{array}{c}\text { Accession No } \\
\text { [SwissProtKB/S } \\
\text { wiss-Prot/ } \\
\text { S.cerevisiae] } \\
\text { (BLAST } \\
\text { Accession No) }\end{array}$ & $\begin{array}{l}\text { Subcellular } \\
\text { localization }\end{array}$ & Description & $\begin{array}{c}\text { Next } \\
\text { match, GI } \\
\text { no (score) }\end{array}$ \\
\hline 150 & FPR1 & 12.08 & 5.71 & 113 & 66 & 45 & gi|157834293 & $\begin{array}{c}\text { 1YAT_A } \\
\text { (NP_014264) }\end{array}$ & Cytoplasm & $\begin{array}{l}\text { Chain A, Improved } \\
\text { Calcineurin Inhibition By } \\
\text { Yeast Fkbp12-Drug } \\
\text { Complexes. } \\
\text { Crystallographic And } \\
\text { Functional Analysis }\end{array}$ & $\begin{array}{c}\text { Fpr1p, } \\
\text { NP_014264 } \\
(66)\end{array}$ \\
\hline 14 & HSP26 & 23.87 & 5.31 & 214 & 121 & 52 & gi|6319546 & NP_009628 & $\begin{array}{l}\text { Cytoplasm } \\
\text { Nucleus }\end{array}$ & $\begin{array}{l}\text { Small heat shock protein } \\
\text { (sHSP) with chaperone } \\
\text { activity; forms hollow, } \\
\text { sphere-shaped } \\
\text { oligomers that suppress } \\
\text { unfolded proteins } \\
\text { aggregation; oligomer } \\
\text { activation requires a } \\
\text { heat-induced } \\
\text { conformational change; } \\
\text { not expressed in } \\
\text { unstressed cells. }\end{array}$ & $\begin{array}{c}\text { Cog7p, } \\
\text { NP_011510 } \\
\text { (40) }\end{array}$ \\
\hline
\end{tabular}




\begin{tabular}{|c|c|c|c|c|c|c|c|c|c|c|c|}
\hline $\begin{array}{l}\text { Spot } \\
\text { No }\end{array}$ & $\begin{array}{l}\text { Gene } \\
\text { name }\end{array}$ & $\begin{array}{l}\text { Mass } \\
{[\mathrm{kDa}]}\end{array}$ & $\mathrm{p} /[\mathrm{pH}]$ & $\begin{array}{c}\text { Sequence } \\
\text { length } \\
{[A A]}\end{array}$ & Score & $\begin{array}{c}\text { Sequence } \\
\text { Coverage } \\
{[\%]}\end{array}$ & GI No & $\begin{array}{c}\text { Accession No } \\
\text { [SwissProtKB/S } \\
\text { wiss-Prot/ } \\
\text { S.cerevisiae] } \\
\text { (BLAST } \\
\text { Accession No) }\end{array}$ & $\begin{array}{l}\text { Subcellular } \\
\text { localization }\end{array}$ & Description & $\begin{array}{c}\text { Next } \\
\text { match, GI } \\
\text { no (score) }\end{array}$ \\
\hline 15 & HSP26 & 23.87 & 5.31 & 214 & 119 & 57 & gi|6319546 & NP_009628 & $\begin{array}{l}\text { Cytoplasm } \\
\text { Nucleus }\end{array}$ & $\begin{array}{l}\text { Small heat shock protein } \\
\text { (sHSP) with chaperone } \\
\text { activity; forms hollow, } \\
\text { sphere-shaped } \\
\text { oligomers that suppress } \\
\text { unfolded proteins } \\
\text { aggregation; oligomer } \\
\text { activation requires a } \\
\text { heat-induced } \\
\text { conformational change; } \\
\text { not expressed in } \\
\text { unstressed cells. }\end{array}$ & $\begin{array}{c}\text { YLR301W, } \\
\text { NP_013404 } \\
\text { (39) }\end{array}$ \\
\hline 13 & $H S P 26$ & 23.87 & 5.31 & 214 & 70 & 42 & gi|6319546 & NP_009628 & $\begin{array}{l}\text { Cytoplasm } \\
\text { Nucleus }\end{array}$ & $\begin{array}{l}\text { Small heat shock protein } \\
\text { (sHSP) with chaperone } \\
\text { activity; forms hollow, } \\
\text { sphere-shaped } \\
\text { oligomers that suppress } \\
\text { unfolded proteins } \\
\text { aggregation; oligomer } \\
\text { activation requires a } \\
\text { heat-induced } \\
\text { conformational change; } \\
\text { not expressed in } \\
\text { unstressed cells. }\end{array}$ & $\begin{array}{c}\text { PLC1, } \\
\text { CAA98003 } \\
(20)\end{array}$ \\
\hline
\end{tabular}




\begin{tabular}{|c|c|c|c|c|c|c|c|c|c|c|c|}
\hline $\begin{array}{l}\text { Spot } \\
\text { No }\end{array}$ & $\begin{array}{l}\text { Gene } \\
\text { name }\end{array}$ & $\begin{array}{l}\text { Mass } \\
{[\mathrm{kDa}]}\end{array}$ & $\mathrm{p} /[\mathrm{pH}]$ & $\begin{array}{c}\text { Sequence } \\
\text { length } \\
{[A A]}\end{array}$ & Score & $\begin{array}{c}\text { Sequence } \\
\text { Coverage } \\
{[\%]}\end{array}$ & GI No & $\begin{array}{c}\text { Accession No } \\
\text { [SwissProtKB/S } \\
\text { wiss-Prot/ } \\
\text { S.cerevisiae] } \\
\text { (BLAST } \\
\text { Accession No) }\end{array}$ & $\begin{array}{l}\text { Subcellular } \\
\text { localization }\end{array}$ & Description & $\begin{array}{c}\text { Next } \\
\text { match, GI } \\
\text { no (score) }\end{array}$ \\
\hline 87 & PGK1 & 44.77 & 7.11 & 416 & 142 & 44 & gi|10383781 & NP_009938 & Cytoplasm & $\begin{array}{l}\text { 3-phosphoglycerate } \\
\text { kinase, catalyzes } \\
\text { transfer of high-energy } \\
\text { phosphoryl groups from } \\
\text { the acyl phosphate of } \\
\text { 1,3-bisphosphoglycerate } \\
\text { to ADP to produce ATP; } \\
\text { key enzyme in glycolysis } \\
\text { and gluconeogenesis. }\end{array}$ & $(-)$ \\
\hline 2 & RIB3 & 22.90 & 5.46 & 208 & 83 & 51 & gi|6320695 & NP_010775 & $\begin{array}{c}\text { Cytoplasm } \\
\text { Mitochondrial } \\
\text { intermembrane } \\
\text { space }\end{array}$ & $\begin{array}{l}\text { 3,4-dihydroxy-2- } \\
\text { butanone-4-phosphate } \\
\text { synthase (DHBP } \\
\text { synthase), required for } \\
\text { riboflavin biosynthesis } \\
\text { from ribulose-5- } \\
\text { phosphate, also has an } \\
\text { unrelated function in } \\
\text { mitochondrial } \\
\text { respiration. }\end{array}$ & $\begin{array}{c}\text { Vacuolar } \\
\text { H+- } \\
\text { ATPase, } \\
\text { AAA66890 } \\
\text { (38) }\end{array}$ \\
\hline 147 & $\begin{array}{c}R P S 21 \\
A\end{array}$ & 9.80 & 5.76 & 87 & 63 & 80 & gi|6322910 & NP_012983 & Cytoplasm & $\begin{array}{l}\text { Protein component of } \\
\text { the small ( } 40 S) \\
\text { ribosomal subunit; } \\
\text { nearly identical to } \\
\text { Rps21Bp and has } \\
\text { similarity to rat } S 21 \\
\text { ribosomal protein. }\end{array}$ & $(-)$ \\
\hline
\end{tabular}




\begin{tabular}{|c|c|c|c|c|c|c|c|c|c|c|c|}
\hline $\begin{array}{c}\text { Spot } \\
\text { No }\end{array}$ & $\begin{array}{l}\text { Gene } \\
\text { name }\end{array}$ & $\begin{array}{l}\text { Mass } \\
{[\mathrm{kDa}]}\end{array}$ & $\mathrm{p} /[\mathrm{pH}]$ & $\begin{array}{l}\text { Sequence } \\
\text { length } \\
{[A A]}\end{array}$ & Score & $\begin{array}{c}\text { Sequence } \\
\text { Coverage } \\
{[\%]}\end{array}$ & GI No & $\begin{array}{c}\text { Accession No } \\
\text { [SwissProtKB/S } \\
\text { wiss-Prot/ } \\
\text { S.cerevisiae] } \\
\text { (BLAST } \\
\text { Accession No) }\end{array}$ & $\begin{array}{l}\text { Subcellular } \\
\text { localization }\end{array}$ & Description & $\begin{array}{c}\text { Next } \\
\text { match, GI } \\
\text { no (score) }\end{array}$ \\
\hline 16 & SEC53 & 29.22 & 5.14 & 254 & 66 & 40 & gi|14318474 & NP_116609 & Cytoplasm & $\begin{array}{l}\text { Phosphomannomutase } \\
\text { involved in synthesis of } \\
\text { GDP-mannose and } \\
\text { dolichol-phosphate- } \\
\text { mannose; required for } \\
\text { folding and glycosylation } \\
\text { of secretory proteins in } \\
\text { the ER lumen. }\end{array}$ & $\begin{array}{c}\text { Hsp26p, } \\
\text { NP_009628 } \\
(43)\end{array}$ \\
\hline 7 & SOD1 & 15.85 & 5.48 & 153 & 64 & 45 & gi|6730103 & $\begin{array}{c}\text { 1B4T_A } \\
\left(\mathrm{NP} \_012638\right)\end{array}$ & $\begin{array}{c}\text { Cytoplasm } \\
\text { Mitochondrion } \\
\text { intermembrane } \\
\text { space }\end{array}$ & $\begin{array}{c}\text { Chain A, Cu (li) Zn } \\
\text { superoxide dismutase }\end{array}$ & $(-)$ \\
\hline 137 & SSA1 & 69.79 & 5.00 & 642 & 94 & 24 & gi|144228166 & NP_009396 & $\begin{array}{l}\text { Cytoplasm } \\
\text { Cell wall } \\
\text { Nucleus }\end{array}$ & $\begin{array}{l}\text { ATPase involved in } \\
\text { protein folding and } \\
\text { nuclear localization } \\
\text { signal (NLS)-directed } \\
\text { nuclear transport; } \\
\text { member of heat shock } \\
\text { protein } 70 \text { (HSP70) } \\
\text { family; forms a } \\
\text { chaperone complex with } \\
\text { Ydj1p. }\end{array}$ & $\begin{array}{l}\text { AWRI1631 } \\
152250, \\
\text { EDZ69338 } \\
(26)\end{array}$ \\
\hline
\end{tabular}




\begin{tabular}{|c|c|c|c|c|c|c|c|c|c|c|c|}
\hline $\begin{array}{l}\text { Spot } \\
\text { No }\end{array}$ & $\begin{array}{l}\text { Gene } \\
\text { name }\end{array}$ & $\begin{array}{l}\text { Mass } \\
{[\mathrm{kDa}]}\end{array}$ & $\mathrm{p} /[\mathrm{pH}]$ & $\begin{array}{c}\text { Sequence } \\
\text { length } \\
{[A A]}\end{array}$ & Score & $\begin{array}{c}\text { Sequence } \\
\text { Coverage } \\
{[\%]}\end{array}$ & GI No & $\begin{array}{c}\text { Accession No } \\
\text { [SwissProtKB/S } \\
\text { wiss-Prot/ } \\
\text { S.cerevisiae] } \\
\text { (BLAST } \\
\text { Accession No) }\end{array}$ & $\begin{array}{l}\text { Subcellular } \\
\text { localization }\end{array}$ & Description & $\begin{array}{c}\text { Next } \\
\text { match, GI } \\
\text { no (score) }\end{array}$ \\
\hline 51 & SSA1 & 37.59 & 5.24 & 339 & 61 & 31 & gi|172713 & $\begin{array}{c}\text { AAA35095 } \\
\text { (NP_009396) }\end{array}$ & $\begin{array}{l}\text { Cytoplasm } \\
\text { Cell wall }\end{array}$ & $\begin{array}{l}70 \mathrm{kDa} \text { heat shock } \\
\text { protein }\end{array}$ & $\begin{array}{l}\text { YLL024Cp- } \\
\text { like protein, } \\
\text { partial, } \\
\text { EDZ70769 } \\
(52)\end{array}$ \\
\hline 138 & SSA2 & 59.81 & 7.00 & 543 & 96 & 27 & gi|207343245 & $\begin{array}{l}\text { EDZ70769 } \\
\text { (NP_013076) }\end{array}$ & $\begin{array}{l}\text { Cytoplasm } \\
\text { Cell wall }\end{array}$ & YLL024Cp-like protein & $\begin{array}{c}\text { AWRI1631 } \\
\text { 152250, } \\
\text { EDZ69338 } \\
(25)\end{array}$ \\
\hline 3 & TPI1 & 26.76 & 5.75 & 247 & 98 & 32 & gi|230405 & $\begin{array}{c}\text { 1YPI_A } \\
\text { (NP_010335) }\end{array}$ & $\begin{array}{l}\text { Cytoplasm } \\
\text { Mitochondrion } \\
\text { Plasma } \\
\text { membrane }\end{array}$ & $\begin{array}{l}\text { Chain A, } \\
\text { Triosephosphate } \\
\text { Isomerase }\end{array}$ & $\begin{array}{c}\text { YER186Cp } \\
\text {-like } \\
\text { protein, } \\
\text { EDZ72486 } \\
(37)\end{array}$ \\
\hline 149 & TSA1 & 21.69 & 5.03 & 196 & 63 & 40 & gi|6323613 & NP_013684 & Cytoplasm & $\begin{array}{l}\text { Ubiquitous } \\
\text { housekeeping } \\
\text { thioredoxin peroxidase, } \\
\text { reduces reactive } \\
\text { oxygen, nitrogen and } \\
\text { sulfur species using } \\
\text { thioredoxin as hydrogen } \\
\text { donor; mediates redox } \\
\text { regulation of the nuclear } \\
\text { localization of Yap1p; } \\
\text { deletion results in } \\
\text { mutator phenotype. }\end{array}$ & $\begin{array}{l}\text { YML028Wp } \\
\text {-like } \\
\text { protein, } \\
\text { partial, } \\
\text { EDZ70249 } \\
(40)\end{array}$ \\
\hline
\end{tabular}




\section{Discussion}

In this thesis, 2D-DIGE was used to search for proteins whose abundance differed between growth of $S$. cerevisiae on glucose or glycerol. The specific goal was to search for changes among enzymes associated with the metabolism of these substrates. The general background concerns the relationship between change in enzyme amount and metabolic output. One qualification is that 2DE generally detects only high abundance soluble and cytoskeletal proteins, although many of the enzymes of carbohydrate metabolism are detected using mammalian samples and appear to be relatively abundant proteins (Beddek et al., 2008; Rawson et al., 2012). At the time my research started there were no other proteomic comparisons of growth on glycerol versus glucose.

\subsection{Proteins identified by MALDI MS}

In this study 179 protein spots were identified from Coomassie stained gels of $100 \mu \mathrm{g}$ protein from cells grown on $2 \%$ glucose. Typically, about $150-200$ proteins can be identified by MALDI MS off the $7 \mathrm{~cm}$ gels used in my work (Beddek et al., 2008; Rawson et al., 2012). MS of protein spots excised from 2DE gels often results in identification of fewer proteins compared to shotgun LC MS/MS of digested cellular extracts, but comparison of abundances of individual proteins is well-established using 2D-DIGE.

The major GO categories of identified proteins were: protein folding, sorting and degradation, transcription, translation, and carbohydrate, amino acid, nucleotide and energy metabolism. The largest group of functionally categorized proteins were involved in carbohydrate metabolism including the sub groups glycolysis/ gluconeogenesis, and fructose and mannose metabolism.

Proteins associated with oxidative phosphorylation and methane metabolism identified in the GO analysis (Figure 15) included seven subunits of the F- and Vtype ATPases (Table 12). Proteins implicated in methane metabolism included the conversion of serine to glycine (Shm1 and Shm2), and glucose and fructose metabolism enzymes (Eno1, Eno2, Fba1, Gpm1 and Pfk2). 
Table 12 - Components of complex V of the electron transport chain.

\begin{tabular}{|c|c|c|c|}
\hline Protein name & Gene name & Description & $\begin{array}{c}\text { Gel A (Figure 13) or B } \\
\text { (Figure 14) } \\
\text { [spot number] }\end{array}$ \\
\hline $\begin{array}{c}\text { ATP synthase } \\
\text { subunit } \alpha\end{array}$ & ATP1 & $\begin{array}{c}\text { a subunit of F-type H+ } \\
\text { transporting ATPase }\end{array}$ & B [122] \\
\hline $\begin{array}{c}\text { ATP synthase } \\
\text { subunit } \beta\end{array}$ & ATP2 & $\begin{array}{c}\text { B subunit of F-type H+- } \\
\text { transporting ATPase }\end{array}$ & A [81] \\
\hline $\begin{array}{c}\text { ATP synthase } \\
\text { subunit } \mathrm{Y}\end{array}$ & ATP3 & $\begin{array}{c}\text { Y subunit of F-type H+- } \\
\text { transporting ATPase }\end{array}$ & B [81] \\
\hline $\begin{array}{c}\text { Vacuolar } \\
\text { membrane } \\
\text { ATPase } \\
\text { subunit B }\end{array}$ & VMA2 & $\begin{array}{c}\text { Subunit B of V-type H+ } \\
\text { transporting ATPase }\end{array}$ & A [89 \& 154] \\
\hline $\begin{array}{c}\text { Vacuolar } \\
\text { membrane } \\
\text { ATPase } \\
\text { subunit E }\end{array}$ & VMA4 & $\begin{array}{c}\text { Subunit E of V-type H+ } \\
\text { transporting ATPase }\end{array}$ & A [124] \\
\hline $\begin{array}{c}\text { Vacuolar } \\
\text { membrane } \\
\text { ATPase } \\
\text { subunit AC39 }\end{array}$ & VMA6 & $\begin{array}{c}\text { Subunit AC39 of V-type H+- } \\
\text { transporting ATPase }\end{array}$ & A [135] \\
\hline $\begin{array}{c}\text { Vacuolar } \\
\text { membrane } \\
\text { ATPase } \\
\text { subunit F }\end{array}$ & VMA7 & $\begin{array}{c}\text { Subunit F of V-type H+- } \\
\text { transporting ATPase }\end{array}$ & A [101] \\
\hline
\end{tabular}

Proteins involved in cysteine and methionine metabolism were Aat2, Aro8, Cys3, Hom2, Sah1, Sam1 and Spe3. Nucleotide metabolism included seven proteins involved in purine processing, Ade13, Adk1, Cdc19, Gua1, Imd2, Imd4 and Ynk1 Ten proteins were involved in protein processing in the endoplasmic reticulum, including Cdc48, Hsc82, Hsp26, Hsp82 and Sse1. Three proteins were components of the ubiquitin ligase complex (Ssa1, Ssa2 and Ssb1). Kar2, a part of a chaperone complex is associated with protein recognition and Pdi1 involved in protein targeting were also identified.

GO analysis indicated proteins associated with phagosomes including actin (Act1) and tubulins, although these high abundance cytoskeletal proteins have widespread functions. Act1 is involved in the initial internalisation and formation of phagosomes (phagocytic cup). Tubulin is involved in phagosome maturation (Tub1 
and Tub2). Four proteins Vma2, Vma4, Vma6 and Vma7 are a part of the vATPase (early, mature and phagolysosome stages).

A large number of ribosomal proteins were identified. Ribosomes are organelles which have a significant role in protein synthesis. They are composed of large and small subunits. Three proteins associated with the large subunit were identified (Rpl11A, Rpl12B and Rpl13A). Twelve proteins associated with the small subunit were identified (Rps0A, Rps12, Rps15, Rps19B, Rps20, Rps21A, Rps22A, Rps27A, Rps3, Rps4B, Rps5 and Rps7A).

\subsection{Carbohydrate and ethanol metabolism}

The primary aim of this study was to examine the differences in abundance of enzymes involved in carbohydrate and ethanol metabolism between growth on glucose or glycerol. The major categories of proteins detected were involved in glycolysis/ gluconeogenesis and mannose metabolism. Proteins associated with the following subgroups were also identified: citric acid cycle, pentose phosphate pathway, galactose, starch and sucrose, amino sugar and nucleotide sugar, pyruvate, glyoxylate and dicarboxylate, propanoate, butanoate and inositol phosphate metabolism.

Most of the enzymes of the glycolytic pathway were identified except for Pgi1 that converts glucose-6-phosphate to fructose-6-phosphate (Figure 21). This protein has, however, been identified by several groups including Shevchenko et al. (1996) and Kolkman et al. (2005), using 2DE. Glycolytic enzymes that were detected included glucokinase Glk1, hexokinase Hxk2, phosphofructokinase Pfk2, fructosebisphosphate aldolase Fba1, and triosephosphate isomerase Tpi1. Although many glycolytic enzymes have been reported in previous proteomic studies, my research seems to be the first detection of phosphofructokinase that has important regulatory properties but seems to be low abundance and not previously identified by 2DE. As expected, for cells grown on glucose, enzymes required for ethanol synthesis were identified (Pdc1 and Adh1). An acetaldehyde dehydrogenase (Ald6) that catalyzes the conversion of aldehyde to acetate (Bruckmann et al., 2009; Huang et al., 2012; Kolkman et al., 2005; Massoni et al., 2009; Shevchenko et al., 1996) was also detected. Proteins associated with metabolism of mannose included mannose-6-phosphate 
isomerase Pmi40, mannose-1-phosphate guanyltransferase Psa1, and phosphomannomutase Sec53.

\subsection{Effect of growth on glucose or glycerol}

Two-dimensional-differential in gel electrophoresis detected proteins that changed in abundance between glucose or glycerol supplementation. Of the approximately 2500 possible protein features (spots) analyzed on the 3-11 DIGE gels, 219 showed $\geq 2$-fold ( $p \leq 0.01)$ change between carbon substrates but many were minor spots on the gels. Only eight proteins were directly identified by MS of spots excised from the 2DDIGE gels, all were greater abundance from cells grown on glucose. Mass spectrometry of tryptic digests of proteins excised from DIGE gels is generally challenging because of the small amounts of proteins on these gels, and potentially also due to modification of some lysine residues by the DIGE reagents.

An additional 18 proteins that varied between cells grown on glucose or glycerol could be matched with reasonable certainty to the database of proteins that was derived using $100 \mu \mathrm{g}$ of protein from cells grown on $2 \%$ glucose (Table 5 and Table 6). GO analysis of the combined set of 26 proteins (Table 13) suggested that carbon substrate affected carbohydrate metabolism and other processes.

Five of the enzymes required for conversion of glucose to ethanol (Pfk2, Fba1, Tpi1, Eno2 and Pdc1) increased approximately 3-9 fold in cells grown on glucose compared to glycerol (Table 13 and Figure 20). The greatest change was for phosphofructokinase (8.8 fold). This result is consistent with that of Foy \& Bhattacharjee (1978) who reported doubling of phosphofructokinase enzyme activity during fermenation compared to oxidative conditions. The final two steps of ethanol synthesis for conversion of pyruvate to acetaldehyde and ethanol are catalyzed by Pdc1 and Adh1 respectively. Pyruvate decarboxylase Pdc1 increased approximately 5-fold during metabolism of glucose but there was not a statistically significant change in the amount of the major ethanol synthesising isoform of alcohol dehydrogenase Adh1. There may have been less than 2-fold changes in enzyme amount that would not have been statistically significant using four biological replicates (Karp \& Lilley, 2005) but the effects of small, or any, change in enzyme amount on metabolic output remains to be determined. 
Several proteins were associated with protein synthesis and processing. Further functional analysis of each protein was obtained from the ExPASy database www.expasy.ch. Rps0A, Rps12, Tif2 and Tif6 have roles as part of the ribosome, RNA transport, and ribosome biogenesis. Rps0A and Rps12 are a part of the small subunit of the ribosome. Tif2 has a role in RNA transport while Tif6 is involved in ribosome biosynthesis. Egd2 is also involved in protein synthesis. The transcriptional protein Ssa1 is a part of splicesosomes.

Proteins involved in folding, sorting and degradation were identified (Ssa1, Sse1, Ssc1). Ssa1 is a heat shock protein which plays a role in protein folding and is also a component of ER-associated degradation. Sse1 is a subunit if the ubiquitin ligase complex were the proteins which represent processing ER. Ssc1 is a mitochondrial heat shock protein.

Other proteins that showed changes in abundance between substrates included an actin binding protein Abp1, the 14-3-3 family proteins Bmh1 and Bmh2, two peptidyl-prolyl cis-trans isomerases Cpr1 and Fpr1 that are associated with protein folding, GMP synthase Gua1, superoxide dismutase (Sod1), the nuclear pore complex protein Srp1 that is implicated in transport of proteins between nucleus and cytoplasm, and Zeo1 that has been associated with cell stress.

Overall these changes suggest potential effects on protein synthesis and processing that may be associated with the experimental design when cells from glycerol cultures were transferred to either glucose or glycerol media. To investigate this potential "stress response" the design could be changed to compare the shift of cells grown in glucose to glycerol. Another approach would be to examine cells grown in either glucose or glycerol for two to three generations prior to proteomic analysis. The identification of proteins from cells grown on glucose should also be extended to MS of proteins from cells grown on glycerol to facilitate analysis of proteins that increase in abundance during metabolism of glycerol, including potentially the glycerol metabolising enzymes Gut1 and 2 that were not identified in the current study. 
Table 13 - The twenty-six varying proteins associated with growth on glucose. Eight proteins were detected by DeCyder ${ }^{\mathrm{TM}}$ analysis $(\geq 2$-fold, $\mathrm{p} \leq 0.01)$ and identified by MS (Table 9$)$ of $(30 \mu \mathrm{g})$ proteins extracted from cells grown in $2 \%$ glucose or $3 \%$ glycerol. The other 18 were matched to spots on the reference gels (Table 10), $100 \mu \mathrm{g}$ proteins extracted from cells grown in $2 \%$ glucose. Average ratio and t-test values are associated with DeCyder ${ }^{\mathrm{TM}}$ data.

\begin{tabular}{|c|c|c|c|c|c|c|}
\hline \multirow{9}{*}{ 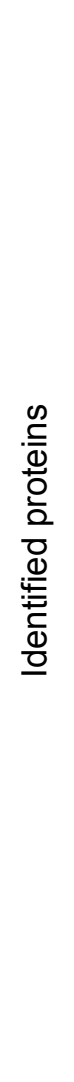 } & $\begin{array}{l}\text { Master No } \\
\text { (Spot No) }\end{array}$ & $\begin{array}{l}\text { Possible } \\
\text { matches }\end{array}$ & $\begin{array}{l}\text { Average } \\
\text { ratio }\end{array}$ & $t$-test & $\begin{array}{l}\text { Protein name } \\
\text { (glycolytic enzymes } \\
\text { are in bold) }\end{array}$ & $\begin{array}{l}\text { Gene } \\
\text { name }\end{array}$ \\
\hline & $1891(16)$ & $\mathrm{N} / \mathrm{A}$ & 2.04 & 0.008 & Phosphomannomutase & SEC53 \\
\hline & $1576(37)$ & $\mathrm{N} / \mathrm{A}$ & 3 & 0.0037 & $\begin{array}{l}\text { Fructose-1,6- } \\
\text { bisphosphate } \\
\text { aldolase }\end{array}$ & FBA1 \\
\hline & $\begin{array}{c}1069 \\
(137 / 138)\end{array}$ & $\mathrm{N} / \mathrm{A}$ & 3.3 & 0.0046 & $\begin{array}{l}\text { Stress-seventy } \\
\text { subfamily A }\end{array}$ & SSA1/2 \\
\hline & $2051(7)$ & $\mathrm{N} / \mathrm{A}$ & 4.1 & 0.0012 & Superoxide dismutase & SOD1 \\
\hline & $1916(17)$ & $\mathrm{N} / \mathrm{A}$ & 4.28 & 0.0046 & $\begin{array}{c}\text { Enhancer of Gal4 DNA } \\
\text { binding }\end{array}$ & EGD2 \\
\hline & $2194(33)$ & $\mathrm{N} / \mathrm{A}$ & 6.04 & 0.0045 & $\begin{array}{l}\text { Cyclosporin A- } \\
\text { sensitive proline } \\
\text { rotamase }\end{array}$ & CPR1 \\
\hline & $1455(97)$ & $\mathrm{N} / \mathrm{A}$ & 6.55 & 0.00021 & Enolase & ENO2 \\
\hline & $2155(150)$ & $\mathrm{N} / \mathrm{A}$ & 7.2 & 4.10E-05 & $\begin{array}{l}\text { Fk 506-senstive } \\
\text { proline rotamase }\end{array}$ & FPR1 \\
\hline \multirow{9}{*}{ 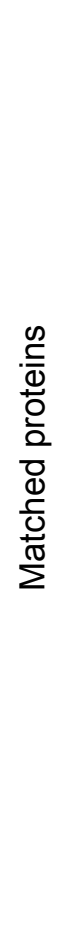 } & 846 & 177 & 5.56 & 0.0021 & Actin-binding protein & $A B P 1$ \\
\hline & 1762 & 128 & 7.1 & 0.00021 & $\begin{array}{l}\text { Brain modulosignalin } \\
\text { homologue } 1\end{array}$ & $B M H 1$ \\
\hline & 1713 & 127 & 5.88 & 0.00014 & $\begin{array}{l}\text { Brain modulosignalin } \\
\text { homologue } 2\end{array}$ & $B M H 2$ \\
\hline & 1408 & 77 & 2.31 & 0.0084 & $\begin{array}{c}\text { Glutamate } \\
\text { dehydrogenase }\end{array}$ & $G D H 1$ \\
\hline & 1267 & 24 & 2.58 & 0.0015 & Guanine Auxotroph & GUA1 \\
\hline & 1216 & 217 & 4.65 & 0.0045 & $\begin{array}{c}\text { Pyruvate } \\
\text { decarboxylase }\end{array}$ & PDC1 \\
\hline & 683 & 200 & 8.76 & 0.00021 & Phosphofructokinase & PFK2 \\
\hline & 1538 & 30 & 2.76 & 0.0079 & $\begin{array}{l}\text { GDP-mannose } \\
\text { pyrophosphorylase }\end{array}$ & PSA1 \\
\hline & 1843 & 139 & 7.35 & 0.00021 & Ribosomal protein of & RPSOA \\
\hline
\end{tabular}




\begin{tabular}{|c|c|c|c|c|c|}
\hline 2042 & 104 & 12.22 & $5.60 \mathrm{E}-05$ & $\begin{array}{c}\text { Ribosomal protein of } \\
\text { the small subunit }\end{array}$ & RPS12 \\
\hline 1231 & 93 & 3.81 & 0.0029 & Supressor of Rpb1 & SRP1 \\
\hline 1047 & 189 & 3.57 & 0.01 & $\begin{array}{c}\text { Stress-seventy } \\
\text { subfamily C }\end{array}$ & SSC1 \\
\hline 863 & 191 & 3.68 & 0.0025 & $\begin{array}{c}\text { Stress-seventy } \\
\text { subfamily E }\end{array}$ & SSE1 \\
\hline 1484 & 147 & 5.18 & 0.0017 & $\begin{array}{c}\text { Translation initiation } \\
\text { factor 2 }\end{array}$ & TIF2 \\
\hline 1923 & 131 & 20.5 & $1.60 \mathrm{E}-05$ & $\begin{array}{c}\text { Translation initiation } \\
\text { factor 6 }\end{array}$ & TIF6 \\
\hline 1900 & 45 & 6.37 & 0.0019 & $\begin{array}{c}\text { Triosephosphate } \\
\text { isomerase }\end{array}$ & TPI1 \\
\hline 2101 & 99 & 16.3 & $1.60 \mathrm{E}-05$ & $\begin{array}{c}\text { Zeocin resistance } \\
\text { srginyl-tRNA }\end{array}$ & YEO1 \\
\hline
\end{tabular}




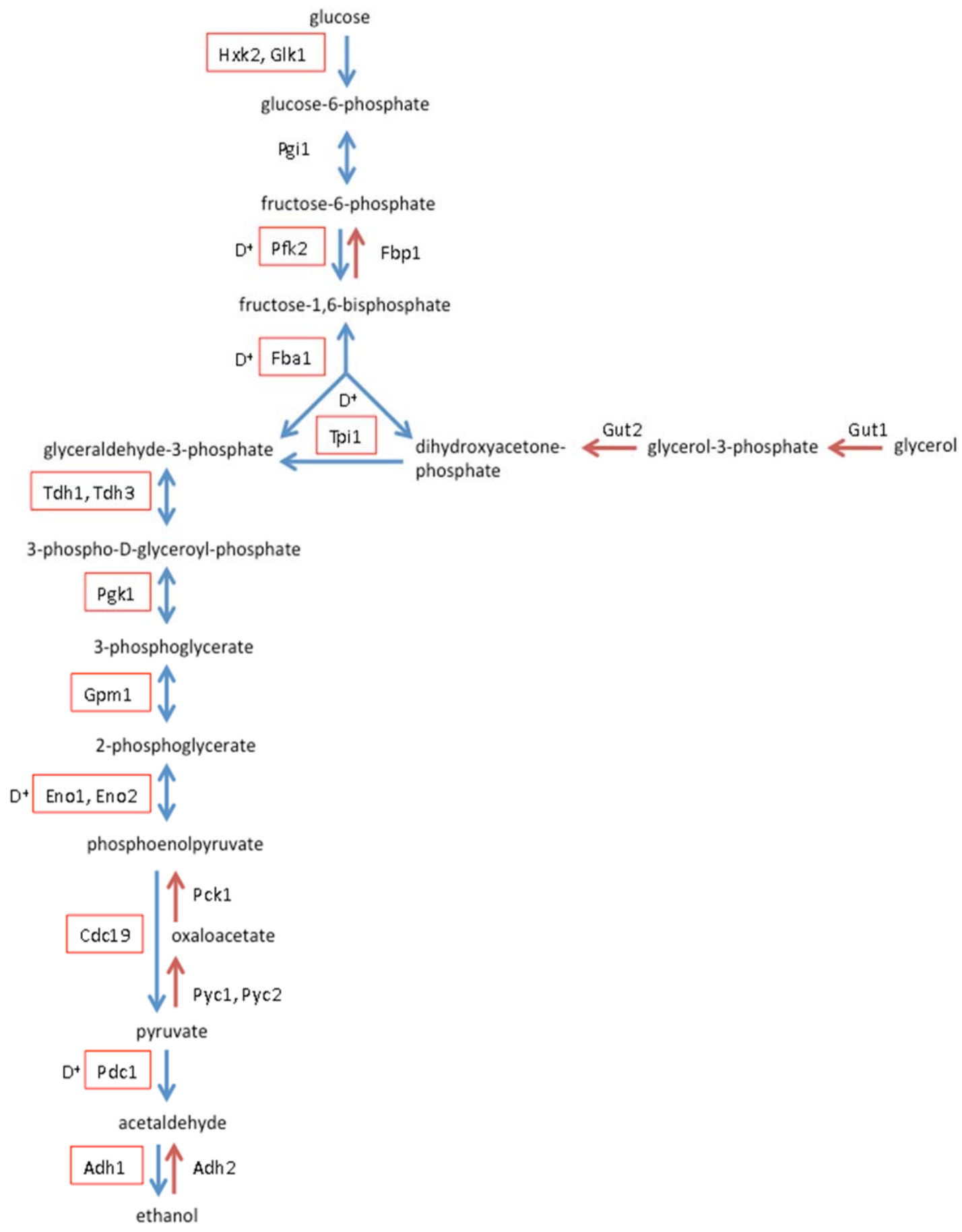

Figure 21 - Proteins involved in glucose and glycerol metabolism. Identified proteins (red box) from cells grown on $2 \%$ glucose were excised from gels containing $100 \mu \mathrm{g}$ protein (Figure 13 and Figure 14). Proteins detected in the 2D-DIGE experiment were labeled with D+ (glucose-based media) or G+ (glycerol-based media) (Table 13). Thirty micrograms of protein was used in the glucose versus glycerol 2D-DIGE experiment. 


\subsection{Changes associated with carbohydrate metabolism}

Metabolic differences between S. cerevisiae during fermentation or oxidation of carbon substrates are well described including the proteomic studies surveyed in the Introduction. One aspect of this study was identification of Pfk2 that is rarely reported, if at all, using 2DE of mammalian or yeast cells. The identification of 26 proteins that changed between glucose or glycerol based media included seven that were involved in carbohydrate metabolism. All seven increased in abundance in cells grown on glucose.

My results are most comparable with those of Stobaugh et al. (2013) who used shotgun MS to examine protein change between shake flask cultures of $S$. cerevisiae. Although protein fractionation methods affected the results (see Introduction Figure 6) their combined results indicated that growth on glucose gave increased abundance of a hexokinase, triosephosphate isomerase and pyruvate decarboxylases, but there was not a significant increase in the detected Adh1 in this research. Also like my results, pyruvate decarboxylase Pdc1 increased with glucose compared to glycerol but they also found relative increase in Pdc5 and 6 for cells grown in glycerol. Other changes reported by Stobaugh et al. (2013) included increases in the final enzyme of the glycerol synthesis pathway. They detected phosphofructokinase and enolase but without significant change in abundance between grown on glucose and glycerol. Although proteomic methodology affects both detection and quantification of proteins, 2D-DIGE is a relatively robust method for comparison of protein abundances.

Similarly, Guidi et al. (2010) showed altered abundances of protein for several glycolytic enzymes between high (2\%) glucose (fermentation) and low (0.5\%) glucose conditions. They found greater abundance of five glycolytic proteins were associated with high glucose conditions including Eno2 and Pdc1, proteins which were detected in this study with growth on glucose. They also detected glyceraldehyde-3phosphate dehydrogenase isozyme 3 Tdh3, phosphoglycerate kinase Pgk1, and Adh1. Therefore, the detection of these glycolytic enzymes, particularly Pdc1 and Adh1 would reasonably suggest greater abundance of enzymes involved in ethanol synthesis in high (2\%) glucose conditions. 
Gutteridge et al. (2010) reported an altered abundance of transcripts and proteins involved in the early stages of glucose metabolism in carbon limited conditions. They identified high glucose affinity transporters Hxt6/7 (glucose-limited conditions) and Hxk1 and Glk1 (linked with carbon sources other than glucose). Although their results are not directly comparable as conditions varied (chemostat cultures and supplemented with $0.25 \%$ glucose), they do provide an insight into other proteins likely to have changed with growth on glycerol.

\subsection{Conclusions and future directions}

The present study has given insight into the proteomic differences between growth on glucose or glycerol. Future studies could include the refinement of proteomics methods and modification of growth conditions. Changes in the proteomic workflow could include use of larger 2D gels to allow detection and identification of more proteins, or use of quantitative shotgun methods such as SILAC or iTRAQ. It is more likely that low abundance proteins would be detected using shotgun analysis. Use of larger numbers of biological replicates, for example $n=10$, would give statistically significant detection of smaller changes in protein amount (Karp \& Lilley, 2005). The growth conditions used showed a potential stress response affecting protein processing in cells shifted from glycerol to glucose. It would be interesting to find out if the transition from cells grown on glucose to glycerol gave a similar response. Subsequent research should investigate the in vivo consequences of change in enzyme amount, this potentially could be done using specific enzyme inhibitors or gene manipulation which is well established for S. cerevisiae. Future studies could therefore combine manipulation of enzyme amounts with proteomic and metabolite analysis.

The overall goal of this research was to examine whether enzyme amounts changed in a metabolically significant way between fermentative growth on glucose and oxidative growth on glycerol. The results showed selective increases among some of the enzymes for conversion of glucose to ethanol for cells grown on glucose. Although this is an expected result the relationship between change in protein amount and metabolic output requires more detailed analysis in many cellular systems. 


\section{References}

Babu, M., Krogan, N. J., Awrey, D. E., Emili, A., \& Greenblatt, J. F. (2009). Systematic characterization of the protein interaction network and protein complexes in Saccharomyces cerevisiae using tandem affinity purification and mass spectrometry. Methods Mol Biol, 548, 187-207.

Beddek, A. J., Rawson, P., Peng, L., Snell, R., Lehnert, K., Ward, H. E., \& Jordan, T. W. (2008). Profiling the metabolic proteome of bovine mammary tissue. Proteomics, 8, 1502-1515.

Bisson, L. F., \& Fraenkel, D. G. (1983). Involvement of kinases in glucose and fructose uptake by Saccharomyces cerevisiae. PNAS, 80, 1730-1734.

Boles, E., Schulte, F., Miosga, T., Freidel, K., Schluter, E., Zimmermann, F. K., Hollenberg, C. P., \& Heinisch, J. J. (1997). Characterization of a glucoserepressed pyruvate kinase (Pyk2p) in Saccharomyces cerevisiae that is catalytically insensitive to fructose-1,6-bisphosphate. J Bacteriol, 179, 2987-2993.

Boucherie, H., Dujardin, G., Kermorgant, M., Monribot, C., Slonimski, P., \& Perrot, M. (1995). Two-dimensional protein map of Saccharomyces cerevisiae: construction of a gene-protein index. Yeast, 11, 601-613.

Brewis, I. A., \& Brennan, P. (2010). Proteomics technologies for the global identification and quantification of proteins. Adv Protein Chem Struct Biol, 80, $1-44$.

Bruckmann, A., Hensbergen, P. J., Balog, C. I., Deelder, A. M., Brandt, R., Snoek, I. S., Steensma, H. Y., \& van Heusden, G. P. (2009). Proteome analysis of aerobically and anaerobically grown Saccharomyces cerevisiae cells. J Proteomics, 71, 662669.

de Godoy, L. M., Olsen, J. V., Cox, J., Nielsen, M. L., Hubner, N. C., Frohlich, F., Walther, T. C., \& Mann, M. (2008). Comprehensive mass-spectrometry-based proteome quantification of haploid versus diploid yeast. Nature, 455, 12511254.

de Smidt, O., du Preez, J. C., \& Albertyn, J. (2008). The alcohol dehydrogenases of Saccharomyces cerevisiae: a comprehensive review. FEMS Yeast Res, 8, 967978.

De Winde, J. H., Crauwels, M., Hohmann, S., Thevelein, J. M., \& Winderickx, J. (1996). Differential requirement of the yeast sugar kinases for sugar sensing in establishing the catabolite-repressed state. Eur J Biochem, 241, 633-643.

Dikicioglu, D., Karabekmez, E., Rash, B., Pir, P., Kirdar, B., \& Oliver, S. G. (2011). How yeast re-programmes its transcriptional profile in response to different nutrient impulses. BMC Syst Biol, 5, 148.

Feldmann, H., Aigle, M., Aljinovic, G., Andre, B., Baclet, M. C., Barthe, C., Baur, A., Becam, A. M., Biteau, N., Boles, E., Brandt, T., Brendel, M., Bruckner, M., Bussereau, F., Christiansen, C., Contreras, R., Crouzet, M., Cziepluch, C., Demolis, N., Delaveau, T., Doignon, F., Domdey, H., Dusterhus, S., Dubois, E., Dujon, B., El Bakkoury, M., Entian, K. D., Feurmann, M., Fiers, W., Fobo, G. M., Fritz, C., Gassenhuber, H., Glandsdorff, N., Goffeau, A., Grivell, L. A., de Haan, M., Hein, C., Herbert, C. J., Hollenberg, C. P., Holmstrom, K., Jacq, C., Jacquet, M., Jauniaux, J. C., Jonniaux, J. L., Kallesoe, T., Kiesau, P., Kirchrath, L., Kotter, P., Korol, S., Liebl, S., Logghe, M., Lohan, A. J., Louis, E. J., Li, Z. Y., 
Maat, M. J., Mallet, L., Mannhaupt, G., Messenguy, F., Miosga, T., Molemans, F., Muller, S., Nasr, F., Obermaier, B., Perea, J., Pierard, A., Piravandi, E., Pohl, F. M., Pohl, T. M., Potier, S., Proft, M., Purnelle, B., Ramezani Rad, M., Rieger, M., Rose, M., Schaaff-Gerstenschlager, I., Scherens, B., Schwarzlose, C., Skala, J., Slonimski, P. P., Smits, P. H., Souciet, J. L., Steensma, H. Y., Stucka, R., Urrestarazu, A., van der Aart, Q. J., van Dyck, L., Vassarotti, A., Vetter, I., Vierendeels, F., Vissers, S., Wagner, G., de Wergifosse, P., Wolfe, K. H., Zagulski, M., Zimmermann, F. K., Mewes, H. W., \& Kleine, K. (1994).

Complete DNA sequence of yeast chromosome II. EMBO J, 13, 5795-5809.

Flick, K. M., Spielewoy, N., Kalashnikova, T. I., Guaderrama, M., Zhu, Q., Chang, H. C., \& Wittenberg, C. (2003). Grr1-dependent inactivation of Mth1 mediates glucose-induced dissociation of Rgt1 from HXT gene promoters. Mol Biol Cell, 14, 3230-3241.

Gancedo, J. M. (1992). Carbon catabolite repression in yeast. Eur J Biochem, 206, 297313.

Gancedo, J. M. (1998). Yeast carbon catabolite repression. Microbiol Mol Biol Rev, 62, 334-361.

Giaever, G., Chu, A. M., Ni, L., Connelly, C., Riles, L., Veronneau, S., Dow, S., LucauDanila, A., Anderson, K., Andre, B., Arkin, A. P., Astromoff, A., El-Bakkoury, M., Bangham, R., Benito, R., Brachat, S., Campanaro, S., Curtiss, M., Davis, K., Deutschbauer, A., Entian, K. D., Flaherty, P., Foury, F., Garfinkel, D. J., Gerstein, M., Gotte, D., Guldener, U., Hegemann, J. H., Hempel, S., Herman, Z., Jaramillo, D. F., Kelly, D. E., Kelly, S. L., Kotter, P., LaBonte, D., Lamb, D. C., Lan, N., Liang, H., Liao, H., Liu, L., Luo, C., Lussier, M., Mao, R., Menard, P., Ooi, S. L., Revuelta, J. L., Roberts, C. J., Rose, M., Ross-Macdonald, P., Scherens, B., Schimmack, G., Shafer, B., Shoemaker, D. D., Sookhai-Mahadeo, S., Storms, R. K., Strathern, J. N., Valle, G., Voet, M., Volckaert, G., Wang, C. Y., Ward, T. R., Wilhelmy, J., Winzeler, E. A., Yang, Y., Yen, G., Youngman, E., Yu, K., Bussey, H., Boeke, J. D., Snyder, M., Philippsen, P., Davis, R. W., \& Johnston, M. (2002). Functional profiling of the Saccharomyces cerevisiae genome. Nature, 418, 387-391.

Goffeau, A., Barrell, B. G., Bussey, H., Davis, R. W., Dujon, B., Feldmann, H., Galibert, F., Hoheisel, J. D., Jacq, C., Johnston, M., Louis, E. J., Mewes, H. W., Murakami, Y., Philippsen, P., Tettelin, H., \& Oliver, S. G. (1996). Life with 6000 genes. Science, 274, 546, 563-547.

Grauslund, M., Lopes, J. M., \& Ronnow, B. (1999). Expression of GUT1, which encodes glycerol kinase in Saccharomyces cerevisiae, is controlled by the positive regulators Adr1p, Ino2 $p$ and Ino4p and the negative regulator Opi1p in a carbon source-dependent fashion. Nucleic Acids Research, 27, 4391-4398.

Guidi, F., Magherini, F., Gamberi, T., Borro, M., Simmaco, M., \& Modesti, A. (2010). Effect of different glucose concentrations on proteome of Saccharomyces cerevisiae. Biochim Biophys Acta, 1804, 1516-1525.

Gutteridge, A., Pir, P., Castrillo, J. I., Charles, P. D., Lilley, K. S., \& Oliver, S. G. (2010). Nutrient control of eukaryote cell growth: a systems biology study in yeast. BMC Biol, 8, 68.

Hohmann, S. (1991). Characterization of PDC6, a third structural gene for pyruvate decarboxylase in Saccharomyces cerevisiae. J Bacteriol, 173, 7963-7969. 
Huang, E. L., Orsat, V., Shah, M. B., Hettich, R. L., VerBerkmoes, N. C., \& Lefsrud, M. G. (2012). The temporal analysis of yeast exponential phase using shotgun proteomics as a fermentation monitoring technique. J Proteomics, 75, 52065214.

Jiang, R., \& Carlson, M. (1996). Glucose regulates protein interactions within the yeast SNF1 protein kinase complex. Genes Dev, 10, 3105-3115.

Johnston, M. (1999). Feasting, fasting and fermenting. Glucose sensing in yeast and other cells. Trends in Genetics, 15, 29-33.

Johnston, M., \& Kim, J. H. (2005). Glucose as a hormone: receptor-mediated glucose sensing in the yeast Saccharomyces cerevisiae. Biochem Soc Trans, 33, 247-252.

Karp, N. A., \& Lilley, K. S. (2005). Maximising sensitivity for detecting changes in protein expression: experimental design using minimal CyDyes. Proteomics, 5 , 3105-3115.

Kim, J. H., Polish, J., \& Johnston, M. (2003). Specificity and regulation of DNA binding by the yeast glucose transporter gene repressor Rgt1. Mol Cell Biol, 23, 5208-5216.

Klose, J. (1975). Protein mapping by combined isoelectric focusing and electrophoresis of mouse tissues. A novel approach to testing for induced point mutations in mammals. Humangenetik, 26, 231-243.

Kolkman, A., Olsthoorn, M. M., Heeremans, C. E., Heck, A. J., \& Slijper, M. (2005). Comparative proteome analysis of Saccharomyces cerevisiae grown in chemostat cultures limited for glucose or ethanol. Mol Cell Proteomics, 4, 1-11.

Lakshmanan, J., Mosley, A. L., \& Ozcan, S. (2003). Repression of transcription by Rgt1 in the absence of glucose requires Std1 and Mth1. Curr Genet, 44, 19-25.

Li, F. N., \& Johnston, M. (1997). Grr1 of Saccharomyces cerevisiae is connected to the ubiquitin proteolysis machinery through Skp1: coupling glucose sensing to gene expression and the cell cycle. EMBO J, 16, 5629-5638.

Lundgren, D. H., Hwang, S. I., Wu, L., \& Han, D. K. (2010). Role of spectral counting in quantitative proteomics. Expert Rev Proteomics, 7, 39-53.

Lunt, S. Y., \& Vander Heiden, M. G. (2011). Aerobic glycolysis: meeting the metabolic requirements of cell proliferation. Annu Rev Cell Dev Biol, 27, 441-464.

Massoni, A., Moes, S., Perrot, M., Jenoe, P., \& Boucherie, H. (2009). Exploring the dynamics of the yeast proteome by means of 2-DE. Proteomics, 9, 4674-4685.

McAlister, L., \& Holland, M. J. (1982). Targeted deletion of a yeast enolase structural gene. Identification and isolation of yeast enolase isozymes. J Biol Chem, 257, 7181-7188.

Moriya, H., \& Johnston, M. (2004). Glucose sensing and signaling in Saccharomyces cerevisiae through the Rgt2 glucose sensor and casein kinase I. PNAS, 101, 1572-1577.

Nagaraj, N., Kulak, N. A., Cox, J., Neuhauser, N., Mayr, K., Hoerning, O., Vorm, O., \& Mann, M. (2012). System-wide perturbation analysis with nearly complete coverage of the yeast proteome by single-shot ultra HPLC runs on a bench top Orbitrap. Mol Cell Proteomics, 11, M111 013722.

O'Farrell, P. H. (1975). High resolution two-dimensional electrophoresis of proteins. J Biol Chem, 250, 4007-4021.

Ong, S. E., \& Mann, M. (2006). A practical recipe for stable isotope labeling by amino acids in cell culture (SILAC). Nat Protoc, 1, 2650-2660. 
Ozcan, S., \& Johnston, M. (1995). Three different regulatory mechanisms enable yeast hexose transporter (HXT) genes to be induced by different levels of glucose. Mol Cell Biol, 15(3), 1564-1572.

Paquin, C. E., \& Williamson, V. M. (1986). Ty insertions at two loci account for most of the spontaneous antimycin A resistance mutations during growth at 15 degrees $\mathrm{C}$ of Saccharomyces cerevisiae strains lacking ADH1. Mol Cell Biol, 6, 70-79.

Perrot, M., Sagliocco, F., Mini, T., Monribot, C., Schneider, U., Shevchenko, A., Mann, M., Jeno, P., \& Boucherie, H. (1999). Two-dimensional gel protein database of Saccharomyces cerevisiae (update 1999). Electrophoresis, 20, 2280-2298.

Pham, T. K., Chong, P. K., Gan, C. S., \& Wright, P. C. (2006). Proteomic analysis of Saccharomyces cerevisiae under high gravity fermentation conditions. $J$ Proteome Res, 5, 3411-3419.

Pham, T. K., \& Wright, P. C. (2007). Proteomic analysis of Saccharomyces cerevisiae. Expert Rev Proteomics, 4(6), 793-813.

Picotti, P., Clement-Ziza, M., Lam, H., Campbell, D. S., Schmidt, A., Deutsch, E. W., Rost, H., Sun, Z., Rinner, O., Reiter, L., Shen, Q., Michaelson, J. J., Frei, A., Alberti, S., Kusebauch, U., Wollscheid, B., Moritz, R. L., Beyer, A., \& Aebersold, R. (2013). A complete mass-spectrometric map of the yeast proteome applied to quantitative trait analysis. Nature, 494, 266-270.

Postma, E., Scheffers, W. A., \& van Dijken, J. P. (1989). Kinetics of growth and glucose transport in glucose-limited chemostat cultures of Saccharomyces cerevisiae CBS 8066. Yeast, 5, 159-165.

Rawson, P., Stockum, C., Peng, L., Manivannan, B., Lehnert, K., Ward, H. E., Berry, S. D., Davis, S. R., Snell, R. G., McLauchlan, D., \& Jordan, T. W. (2012). Metabolic proteomics of the liver and mammary gland during lactation. J Proteomics, 75, 4429-4435.

Righetti, P. G., \& Bossi, A. (1997). Isoelectric focusing in immobilized pH gradients: recent analytical and preparative developments. Anal Biochem, 247, 1-10.

Roberts, G. G., \& Hudson, A. P. (2006). Transcriptome profiling of Saccharomyces cerevisiae during a transition from fermentative to glycerol-based respiratory growth reveals extensive metabolic and structural remodeling. Mol Genet Genomics, 276, 170-186.

Rodriguez, A., De La Cera, T., Herrero, P., \& Moreno, F. (2001). The hexokinase 2 protein regulates the expression of the GLK1, HXK1 and HXK2 genes of Saccharomyces cerevisiae. Biochem J, 355, 625-631.

Rolland, F., Winderickx, J., \& Thevelein, J. M. (2002). Glucose-sensing and -signalling mechanisms in yeast. FEMS Yeast Res, 2, 183-201.

Ross, P. L., Huang, Y. N., Marchese, J. N., Williamson, B., Parker, K., Hattan, S., Khainovski, N., Pillai, S., Dey, S., Daniels, S., Purkayastha, S., Juhasz, P., Martin, S., Bartlet-Jones, M., He, F., Jacobson, A., \& Pappin, D. J. (2004). Multiplexed protein quantitation in Saccharomyces cerevisiae using aminereactive isobaric tagging reagents. Mol Cell Proteomics, 3, 1154-1169.

Seeboth, P. G., Bohnsack, K., \& Hollenberg, C. P. (1990). pdc1(0) mutants of Saccharomyces cerevisiae give evidence for an additional structural PDC gene: cloning of PDC5, a gene homologous to PDC1. J Bacteriol, 172, 678-685.

Shevchenko, A., Jensen, O. N., Podtelejnikov, A. V., Sagliocco, F., Wilm, M., Vorm, O., Mortensen, P., Boucherie, H., \& Mann, M. (1996). Linking genome and 
proteome by mass spectrometry: large-scale identification of yeast proteins from two dimensional gels. PNAS, 93, 14440-14445.

Smith, M. G., Des Etages, S. G., \& Snyder, M. (2004). Microbial synergy via an ethanol-triggered pathway. Mol Cell Biol, 24, 3874-3884.

Sprague, G. F., \& Cronan, J. E. (1977). Isolation and characterization of Saccharomyces cerevisiae mutants defective in glycerol catabolism. J Bacteriol, 129, 1335-1342.

Stahlberg, A., Elbing, K., Andrade-Garda, J. M., Sjogreen, B., Forootan, A., \& Kubista, M. (2008). Multiway real-time PCR gene expression profiling in yeast Saccharomyces cerevisiae reveals altered transcriptional response of ADHgenes to glucose stimuli. BMC Genomics, 9, 170.

Stobaugh, J. T., Fague, K. M., \& Jorgenson, J. W. (2013). Prefractionation of intact proteins by reversed-phase and anion-exchange chromatography for the differential proteomic analysis of Saccharomyces cerevisiae. J Proteome Res, 12, 626-636.

Treitel, M. A., Kuchin, S., \& Carlson, M. (1998). Snf1 protein kinase regulates phosphorylation of the Mig1 repressor in Saccharomyces cerevisiae. Mol Cell Biol, 18, 6273-6280.

Unlu, M., Morgan, M. E., \& Minden, J. S. (1997). Difference gel electrophoresis: a single gel method for detecting changes in protein extracts. Electrophoresis, 18, 2071-2077.

Usaite, R., Wohlschlegel, J., Venable, J. D., Park, S. K., Nielsen, J., Olsson, L., \& Yates Iii, J. R. (2008). Characterization of global yeast quantitative proteome data generated from the wild-type and glucose repression saccharomyces cerevisiae strains: the comparison of two quantitative methods. J Proteome Res, 7, 266-275.

Walton, J. D., Paquin, C. E., Kaneko, K., \& Williamson, V. M. (1986). Resistance to antimycin $\mathrm{A}$ in yeast by amplification of ADH4 on a linear, $42 \mathrm{~kb}$ palindromic plasmid. Cell, 46(6), 857-863.

Wiesenfeld, M., Schimpfessel, L., \& Crokaert, R. (1975). Multiple forms of mitochondrial alcohol dehydrogenase in Saccharomyces cerevisiae. Biochim Biophys Acta, 405, 500-512.

Wu, G., Nie, L., \& Zhang, W. (2008). Integrative analyses of posttranscriptional regulation in the yeast Saccharomyces cerevisiae using transcriptomic and proteomic data. Curr Microbiol, 57, 18-22.

Yin, Z., Wilson, S., Hauser, N. C., Tournu, H., Hoheisel, J. D., \& Brown, A. J. (2003). Glucose triggers different global responses in yeast, depending on the strength of the signal, and transiently stabilizes ribosomal protein mRNAs. Mol Microbiol, 48, 713-724.

Young, E. T., \& Pilgrim, D. (1985). Isolation and DNA sequence of ADH3, a nuclear gene encoding the mitochondrial isozyme of alcohol dehydrogenase in Saccharomyces cerevisiae. Mol Cell Biol, 5, 3024-3034. 